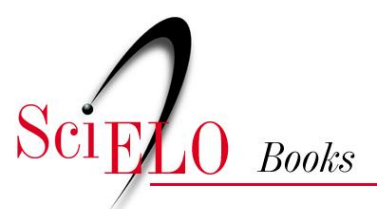

\title{
Visões do feminino \\ a medicina da mulher nos séculos XIX e XX
}

Ana Paula Vosne Martins

MARTINS, APV. Visões do feminino: a medicina da mulher nos séculos XIX e XX [online]. Rio de Janeiro: Editora Fiocruz, 2004, 287 p. História e Saúde collection. ISBN 978-85-7541-451-4. Available from SciELO Books $<$ http://books.scielo.org $>$.

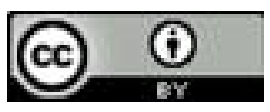

All the contents of this work, except where otherwise noted, is licensed under a Creative Commons Attribution 4.0 International license.

Todo o conteúdo deste trabalho, exceto quando houver ressalva, é publicado sob a licença Creative Commons Atribição 4.0.

Todo el contenido de esta obra, excepto donde se indique lo contrario, está bajo licencia de la licencia Creative Commons Reconocimento 4.0. 
Visões do Femíníno

a medicina da mulher nos séculos XIX e XX 


\section{FUNDAÇÃO OSWALDO CRUZ}

Presidente

Paulo Marchiori Buss

Vice-Presidente de Desenvolvimento Institucional, Informação e Comunicação

Paulo Gadelha

\section{EDITORA FIOCRUZ}

Coordenador

Paulo Gadelha

Conselho Editorial

Carla Macedo Martins

Carlos E. A. Coimbra Jr.

Charles Pessanha

Gilberto Hochman

Jaime L. Benchimol

José da Rocha Carvalheiro

José Rodrigues Coura

Luis David Castiel

Luiz Fernando Ferreira

Maria Cecília de Souza Minayo

Miriam Struchiner

Paulo Amarante

Vanize Macêdo

Coordenador Executivo

João Carlos Canossa P. Mendes

Coleção História e Saúde

Editores Responsáveis: Jaime L. Benchimol

Flávio C. Edler

Gilberto Hochman 
Visões do Feminíno

a medicina da mulher nos séculos XIX e XX

Ana Paula Vosne Martins 
Copyright (C) 2004 da autora

Todos os direitos desta edição reservados à

FUNDAÇÃO OSWALDO CRUZ / EDITORA

ISBN: 85-7541-048-2

Capa e projeto gráfico

Angélica Mello, Guilherme Ashton e Daniel Pose

Ilustração da capa

O Eterno Feminino (1875-1877), Paul Cézanne

Editoração eletrônica

Guilherme Ashton

Revisão

Cíntia Bravo de Souza

Supervisão editorial

Janaina de Souza Silva

Catalogação-na-fonte

Centro de Informação Científica e Tecnológica

Biblioteca da Escola Nacional de Saúde Pública Sergio Arouca

M386v

Martins, Ana Paula Vosne

Visões do feminino: a medicina da mulher nos séculos XIX e

XX. / Ana Paula Vosne Martins. Rio de Janeiro: Editora Fiocruz, 2004.

288p. ilus (Coleção História e Saúde)

1.Saúde da Mulher. 2.Medicina Reprodutiva-História.

3.História da Medicina Moderna. 4.Identidade de Gênero

5. Conhecimento. I.Título.

CDD - 20.ed. - 613.04244

2004

EDITORA FIOCRUZ

Av. Brasil, 4036 - $1^{\circ}$ andar - sala 112 - Manguinhos

21041-361 - Rio de Janeiro - RJ

Tel.: (21) 3882-9039 e 3882-9041

Telefax: (21) 3882-9006

e-mail: editora@fiocruz.br

http://www.fiocruz.br

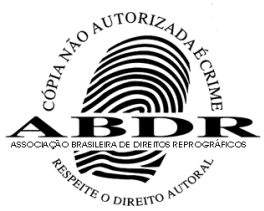




\section{Sumárío}

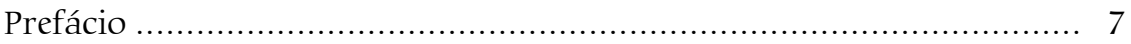

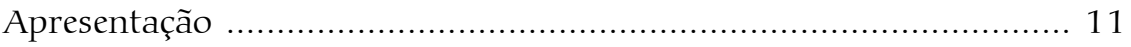

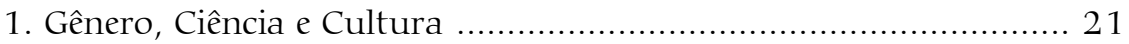

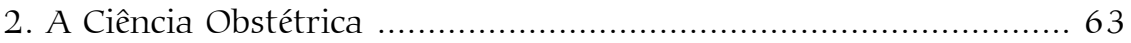

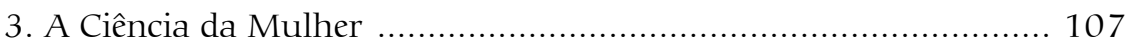

4. A Obstetrícia e a Ginecologia no Brasil ................................... 139

5. O Médico de Senhoras e a Clínica de Mulheres .......................... 171

6. A Mulher no Discurso Médico e Intelectual Brasileiro ................ 217

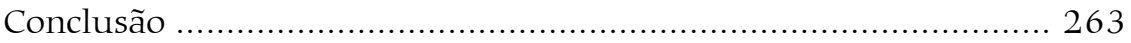

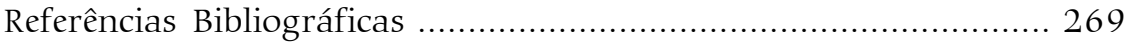




\section{Prefácí}

Este livro aborda um tema recorrente na literatura e no pensamento ocidental que mobilizou, ao longo do tempo, artistas, poetas, filósofos, cientistas e religiosos. Trata-se do corpo feminino. Louvado, diabolizado ou mitificado, cada época devotou a este corpo olhares, expectativas e significados diversos.

Nas últimas décadas do século XX, para além de todas essas presenças, 'o corpo' assumiu também um lugar de destaque nas discussões feministas e nas análises de gênero, a ponto de ser identificado como uma categoria da teoria social. É muito vasta e importante esta produção a respeito do corpo. Um de seus segmentos é constituído pelo discurso feminista que analisou a construção do pensamento misógino patriarcalista em relação às mulheres e à feminilidade. Procurou-se evidenciar como esse discurso tinha como base a depreciação dos corpos femininos - considerados mais frágeis e imperfeitos em relação ao dos homens - e o pressuposto do dualismo mente/ corpo, associado, geralmente, à oposição macho/fêmea. Dessa forma, as mulheres estariam bem mais ligadas ao corpo do que os homens, o que restringiria seus papéis e atuações sociais. As teorias feministas procuraram desconstruir tais representações, que, justificadas em um biologismo essencialista, buscavam explicar características culturais e comportamentais. Demonstraram, assim, que, ao invés de uma natureza feminina única, 'a mulher' foi aprisionada em seu próprio corpo para ser controlada e oprimida.

Visões do Feminino, de Ana Paula Vosne Martins, dialoga com os estudos feministas, incorpora algumas posições, mas, de certa forma, envereda por um caminho diverso, já que procura compreender o significado e a importância da medicina na construção e, especialmente, na consolidação 
de um pensamento misógino no século XIX, a partir do desenvolvimento da ginecologia e da obstetrícia. A autora elucida como o saber médico conferiu às mulheres uma identidade comum e fez do corpo um lugar privilegiado, do qual emanava a mais profunda identidade feminina.

O ponto de partida do livro é, portanto, o discurso científico e as reflexões dos médicos, entre finais do século XVIII e a segunda metade do século XIX, sobre a singularidade do corpo feminino e suas patologias, bem como sobre seu sistema reprodutivo.

A historiadora dirige o leitor pelos obscuros e incertos caminhos das recentes especialidades médicas que despontavam em meados do século XIX; mas, fundamentalmente, os leitores são levados a constatar dois embates de ampla envergadura nos quais estavam em jogo conhecimento e poder: de um lado, o embate entre os próprios homens da ciência sobre as descobertas e experiências que realizavam no corpo de suas pacientes e a disputa pela primazia desse conhecimento. Uma batalha, enfim, pelo avanço científico, pela introdução de novas tecnologias e exploração do corpo humano; batalha esta que ocorreu no interior das clínicas e das salas de cirurgia, mas que ultrapassou esses espaços ao ganhar projeção, delimitando os rumos da ciência médica moderna. De outro lado, o leitor acompanha um embate travado nos bastidores, por trás das cortinas que encobriram o corpo exposto das mulheres por vários séculos. Trata-se do longo e tumultuado caminho pela conquista de um saber até então restrito às mulheres e que continha os segredos sobre seus próprios corpos e os ritos dos quais participavam, como a maternidade, o prazer sexual, as funções e disfunções dos órgãos e, finalmente, o envelhecimento. Segredos estes que, depois de devassados, permitiram que os homens da ciência entrassem em cena, desafiando o domínio e o poder das mulheres sobre seus corpos, a ponto de obstetras e ginecologistas serem considerados como 'especialistas em mulheres'.

Este livro é uma obra que aborda a constituição desse saber por parte dos doutores, procedendo a uma minuciosa análise do discurso médico na Europa e no Brasil. Não descuida, porém, daquele que é o objeto primordial do ofício do historiador: os agentes históricos. Dessa forma, as práticas médicas e as experiências das pacientes despontam no livro de maneira decisiva, revelando os rostos, as identidades e os sentimentos dessas personagens.

Resultado de um trabalho de anos de investigação e reflexão histórica, esta obra consolida a trajetória firme e segura de uma historiadora preocupada com as questões de gênero, sensível aos debates historiográficos 
contemporâneos e aos rumos da história do Brasil. Escrito em uma linguagem clara, sem jargões e de agradável leitura, o livro, ao mesmo tempo em que problematiza questões pouco pesquisadas, informa e atrai a atenção dos leitores para um tema polêmico e atual - o controle e domínio dos corpos.

A obra chega ao público em um momento, como bem lembrou sua autora, em que as mulheres - e eu acrescentaria os homens também ou até mais - 'estão cada vez mais presos ao domínio de seus corpos' sujeitando-se a interferências múltiplas da medicina para se adequarem a modelos e finalidades específicas impostos pela sociedade.

Nesse sentido, este livro conduz os leitores ao início, poderíamos dizer, de um movimento de moldagem, adequação e controle do corpo feminino a uma função social específica - a maternidade - que há décadas vem sendo contestada pelas próprias mulheres na busca pelo reconhecimento de seus múltiplos papéis sociais. A obra empresta, desse modo, um vivo colorido a este debate, tanto pelo que revela do nosso passado quanto pela atualidade das questões que desperta.

Por todos esses motivos, participar com Ana Paula Vosne Martins da trajetória desse livro - bem mais como colega e ouvinte do que como professora ou orientadora de um trabalho acadêmico - foi uma experiência intelectual e pessoal rica e abrangente, que espero, cative o leitor da mesma forma como me envolveu ao longo desses anos.

Leila Mezan Algranti

Professora do Departamento de História da Universidade Estadual de Campinas (Unicamp) 


\section{Apresentação}

Existem momentos na vida onde a questão de saber se se pode pensar diferentemente do que se pensa, e perceber diferentemente do que se vê,é indispensável para continuar a olhar ou refletir.

Michel Foucault (1984: 13)

A historiadora Yvonne Knibiehler perguntou em um artigo seu publicado pela revista Annales em 1976, por que ocorreu uma regressão na condição feminina após a Revolução Francesa, em particular no começo do século XIX, regressão esta que marcou profundamente a vida pública e privada das mulheres. A autora explica que as mulheres do período prérevolucionário e mesmo as das primeiras fases da Revolução tiveram importante participação política, exercitando seus direitos de republicanas ao expressar livremente suas idéias, reivindicar os direitos civis, fundando clubes onde discutiam política e elaboravam propostas visando à melhoria das condições de vida das cidadãs. Knibiehler compara esse momento de intensa participação e atuação das mulheres com o processo duplo de exclusão da vida política e de reclusão à esfera doméstica, ocorrido logo depois, salientando o papel dos médicos e da constituição de um discurso científico voltado para as diferenças sexuais com a finalidade de demarcar espaços políticos de gênero cuja fundamentação não estava na religião, mas na forma de conhecimento mais elevada da razão humana: a Ciência.

Saltemos no tempo. O espaço pode ser qualquer grande cidade ocidental do final do século XX: São Paulo, Nova Iorque, Tóquio, Londres, geografias urbanas marcadas por grande diversidade cultural, pela 
hegemonia dos valores de mercado, por uma grande concentração populacional e pelo bombardeio das imagens publicitárias. Neste nosso tempo, homens e mulheres, na sua maioria, já não têm espaços segregados, e não é politicamente correto estabelecer classificações sociais baseadas no gênero ou na cor da pele pessoas. As mulheres deste final de século competem por cargos e posições com as mesmas estratégias e formação intelectual que os homens, embora continuem ganhando salários menores e tendo de se desdobrar em vários papéis - profissional bem-sucedida, mãe, esposa, administradora do lar - já que o trabalho doméstico geralmente é realizado por uma mulher, empregada doméstica -, além de ter de 'parecer' sempre saudável, bem disposta e atraente para o sexo.

Evidentemente que já não se recorre à ciência e à medicina para afirmar que a mulher é inferior ao homem, como ocorreu nos séculos XVIII e XIX. A questão hoje não é a inferioridade física ou mental, mas a adequação dos corpos e comportamentos a modelos de eficácia, produtividade e competitividade, regidos por um complexo mecanismo social de normatização das pessoas. Embora a normatização dos corpos e comportamentos atinja homens e mulheres, são estas os principais alvos-objetos dos diferentes tipos de discursos que, à sua maneira e com formas de expressão fundamentalmente visuais, procuram 'enquadrar' as mulheres, transformando-as, na sua corporalidade e subjetividade, em mulheres 'normais'.

No entanto, ser normal para as mulheres não é apenas se adequar a um modelo de comportamento competitivo na sociedade de mercado. O significado de normalidade passa, necessariamente, pelo ser mulher, e esta condição é indissociável do parecer, da auto-representação do eu feminino, cujo suporte material e simbólico é o corpo.

Embora não se subestimem aqui as conquistas dos direitos fundamentais para o exercício da cidadania, não há como deixar de questionar o rumo da modernização das relações de gênero e o que isso significou para as mulheres. Se, por um lado, a utopia da igualdade de gênero do século XVIII vem se tornando realidade para nós, homens e mulheres do final do século XXI, por outro lado, houve uma reorganização estratégica nas relações de poder e nas práticas de controle social, mais sutis, menos centralizadas, mas nem por isso menos rígidas na sua efetivação; ao contrário, pois se os modelos de normalidade do século XIX eram igualmente rígidos e passavam pela disciplinarização dos corpos 
femininos, seu alcance era mais limitado atingindo primeiro a burguesia e só mais para o final do século as classes trabalhadoras.

O que defendemos a partir da investigação realizada sobre os discursos normativos do corpo feminino é que sua transformação em lugar prático de controle social, cujos inícios nos propomos a estudar aqui, acentuou-se muito, atingindo segmentos da sociedade bastante diferenciados culturalmente através dos meios de comunicação de massa.

Com a entrada efetiva das mulheres no mercado de trabalho, na política e nos centros de produção do conhecimento e de tecnologia, desenvolveramse, concomitantemente, novos mecanismos de controle sobre os corpos femininos, todos exigindo um grande investimento de energia, de tempo, de dinheiro e de engajamento emocional das mulheres. Tem-se, assim, um estranho paradoxo: por um lado, a mídia divulga e apóia a chamada libertação das mulheres do domínio patriarcal; por outro, as mulheres estão mais presas do que nunca ao domínio de seus corpos, fazendo de tudo que podem para transformá-los em obras perfeitas, expressão de feminilidade, de beleza, de saúde e de controle sobre si mesmas. São prisioneiras de seus próprios corpos porque nunca chegam ao ideal da perfeição ou, quando estão próximas do que consideram seu ideal, não podem relaxar, pois o corpo é um tirano que exige constante atenção e cuidados.

Não se trata de negar o bom e necessário cuidado consigo mesmo, mas de ressaltar a transformação do cuidado do corpo em uma prisão e até mesmo em uma obsessão que pode levar à doença e à morte, como atestam as bulímicas e anoréxicas. Questionam-se os mecanismos de controle social, formulados por agentes de discursos diferenciados que continuam, em verdade, a afirmar que o destino das mulheres está inexoravelmente ligado aos seus corpos, e não ao seu desejo, negando a subjetividade como o fizeram os médicos e cientistas dos séculos passados. Só assim pode-se entender o significado e a violência simbólica de um painel publicitário de um produto dietético em que uma bela e jovem mulher magra vestindo uma roupa justa e bebendo o produto é apresentada com a frase: 'Ser feliz é poder entrar num vestido $\mathrm{P}^{\prime}$.

Esta imagem que associa felicidade à magreza é bastante reveladora da dinâmica dos mecanismos de controle que transmitem a mensagem de que as mulheres continuam dependendo de seus corpos para serem aceitos socialmente e construírem suas identidades. Fora deste modelo só existem a feiúra, o descontrole e a solidão, como se vê em outra campanha publicitária 
de um iogurte light, divulgada na televisão. Nesta, um grupo de jovens brancos, belos, magros e sorridentes, tomando o iogurte, passa por uma jovem gorda carregando várias guloseimas. A mensagem não deixa dúvidas: ela está só porque é gorda e porque não consome o produto anunciado.

Queremos apontar para a semelhança entre a representação moderna da mulher-corpo e a representação médico-científica produzida pelos saberes que foram objetos deste livro, mesmo porque as imagens e os mecanismos de controle sobre a mulher hoje não são apenas produtos do mercado fazem parte de uma história da produção de saberes e práticas sobre o corpo feminino, cujas origens estão em outros domínios: as ciências biológicas e a medicina da mulher.

Portanto, a resposta para a pergunta de Knibiehler sobre o que teria levado à exclusão das mulheres da esfera pública e à sua reclusão ao espaço doméstico deve ser procurada na mesma formação discursiva que resultou nas atuais cadeias do corpo feminino. As ciências biológicas e a medicina da mulher contribuíram decisivamente para esse longo processo de 'in-corporação' das mulheres. Esses saberes não criaram algo totalmente novo sobre a mulher, já que havia uma tradição sobre o assunto. O que eles fizeram foi dar um novo significado para esta tradição, ao mesmo tempo que se diferenciavam dela porque individualizaram seu objeto, produziram um vocabulário e um conjunto de imagens realistas com o intuito de alcançar sua verdade e, assim o fazendo, fixaram-no na ordem imutável das coisas ditas, dos nomes, das representações. Portanto, como uma mulher podia desejar estudar medicina ou dedicar-se à filosofia e às artes se, ao fazê-lo, estava infringindo as leis naturais, almejando algo para o qual seu corpo e seu espírito não foram preparados? Ou seja, desejavam 'ser homens' e isto era contrário à Natureza, o que só podia resultar em desordem tanto para o corpo feminino quanto para o corpo social.

Mais do que afirmar que as mulheres foram destinadas pela Natureza ao exercício da função reprodutiva, a medicina da mulher provava com dados estatísticos e argumentos materialistas o fardo do corpo sobre as existências femininas; em contrapartida, acenava com as delícias reservadas àquelas que seguissem seu destino natural, promovendo a mulher-mãe e o exercício da maternidade a uma função não só natural, mas de ordem moral e política. Contudo, tais idéias não surtiriam efeitos se não houvesse reconhecimento da autoridade dos discursos médico e científico. Esta autoridade foi construída no processo de profissionalização dos médicos e cirurgiões e na utilização dos novos conhecimentos produzidos pelas 
ciências biológicas, especialmente no século XIX. Como representantes da ciência e arautos do bem-estar físico e moral das pessoas, os médicos passaram a ser respeitados e incorporados aos meios sociais mais privilegiados, não só como especialistas em assuntos de saúde e das doenças, mas como conselheiros da arte de bem viver. Nesse sentido, adquiriram um status tão ou mais privilegiado que os padres e pastores.

Foi nesse mesmo movimento de ascensão social e aquisição de prestígio que desenvolveram o que chamamos aqui de pastoral moderna, voltada para a família e em especial para a mulher: o corpo e o espírito da instituição familiar. Os médicos não só estudaram a especificidade da mulher, a reprodução e as doenças ginecológicas, mas também formularam uma definição de seu ser social fundada na natureza, ou melhor dizendo, no seu corpo.

Ao objetivar o corpo feminino no interior de um saber especializado, passaram a se autodenominar 'especialistas da mulher' e a afirmar que sua natureza específica, sua particularidade sexual, demandava não só explicações científicas, mas também um regime de regulações para que a natureza feminina não se desvirtuasse, já que o corpo feminino deveria ser regulado, porque os médicos acreditavam que, além de ser mais frágil, era impressionável a qualquer motivação, fosse ela causada por emoções, pela visão, pelo tato, enfim, um corpo sensível a qualquer impressão.

A transformação do corpo feminino em objeto de conhecimento, a formulação de discursos normativos para o bom desempenho de suas funções reprodutivas e sociais, bem como a produção de representações científicas, nos permitem pensar em um processo de gerenciamento dos corpos femininos sem precedentes até meados do século XIX.

A idéia de gerenciamento é bastante útil se pensarmos no amplo conjunto de discursos normativos que procurava fundar na Natureza as diferenças produzidas na vida social para manter hierarquias e relações de dominação. Como não pensar em gerenciamento ao analisarmos os tratados de obstetrícia e ginecologia, cujos saberes tornaram o corpo feminino visível e inteligível? A mulher deixava de ser uma idéia, uma abstração ou um mistério, ao ter seu corpo revelado pela ciência ocular.

O gerenciamento do corpo feminino completou-se com a ginecologia, ao racionalizar a sexualidade feminina e ao transformar seu corpo em um objeto analisável, mensurável e sujeito a diversas práticas de objetivação. Também o gerenciamento está presente nos esforços dos médicos para convencer as mulheres a se tornarem pacientes, a confiarem nos 
especialistas, a pautarem suas vidas pela higiene e pelos conselhos médicos, a procurarem desempenhar as funções de esposa e mãe como um dever sagrado e natural e, por fim, a se definirem como mulher, tomando seus corpos como fundamento de identidade e de devir.

Ao iniciar o século XXI, vemos que esse mesmo gerenciamento dos corpos femininos não se alterou. Hoje não pesam nossos cérebros, nem nos reduzem à materialidade de nossos úteros e ovários. No entanto, nossos corpos continuam a forjar nossos destinos, a nos pregar peças, seja porque o nível de serotonina esteja muito baixo nos levando à depressão, seja porque ficamos 'diferentes' antes e durante a menstruação, ou então porque simplesmente não conseguimos nos adequar aos padrões de beleza...

Da mesma forma que, no século XIX, precisavam dos médicos para curá-las da histeria, algumas mulheres do início do século XXI continuam a precisar de especialistas do corpo, só que a abrangência é maior, pois o corpo passou a depender do cuidado de um número maior de especialistas das mais diversas especialidades: esteticistas, estilistas, personal trainers, nutricionistas, sem falar na grande quantidade de terapeutas corporais.

A questão política que hoje, tal como ontem, precisa ser problematizada, é a relação entre liberdade e corporalidade. No passado, o discurso normativo encerrou as mulheres no lar ao ligar seu destino às amarras biológicas de um corpo frágil, no limite entre o normal e o patológico. O corpo era então o entrave para a liberdade de ação. Hoje, o corpo continua sendo um entrave, só que de maneira mais sutil, como componente de um discurso que rima com liberdade, juventude e felicidade. Para as mulheres em especial, os apelos em favor de um corpo eternamente jovem, saudável, belo e sedutor, as transforma em consumidoras vorazes, mas ao mesmo tempo insatisfeitas, incompletas e extremamente individualistas. Quando se fala na liberdade das mulheres, invariavelmente a discussão se remete aos direitos políticos e civis ou, no máximo, ao controle da natalidade, que teria possibilitado a elas viver com mais liberdade sua vida sexual.

O que se silencia é que a liberdade não pode ser compreendida como sinônimo de acesso aos direitos civis e políticos. A liberdade é um conceito que, necessariamente, envolve o engajamento do ser humano na sua integralidade física, emocional e social. O processo pelo qual as mulheres foram trancafiadas em seus corpos foi o que nos motivou a desenvolver este estudo, evidenciando o papel que a ciência sexual e a medicina da mulher 
tiveram na construção de uma imagem feminina ancorada no corpo, bem como de uma identidade marcada pela relação com o corpo e a função reprodutiva.

O que questionamos é - salvo as possibilidades de escolha que hoje estão abertas a algumas mulheres - que a prisão de muitas delas em seus corpos continua sendo uma barreira à livre expressão, pois a energia e o tempo dispensados no trato do corpo em busca de um ideal de felicidade e de realização plena significam, como bem analisou a filósofa Susan Bordo (Jaggar \& Bordo, 1997), que está ocorrendo uma derrota política em nossos próprios corpos. Somente a superação dos corpos dóceis e úteis pode nos levar a uma existência mais agradável e menos obsessiva. Enfim, a um encontro entre nossas cabeças, nossos sentimentos e nossos corpos.

Procurar pelas origens desta construção cultural dos corpos femininos foi o objetivo principal deste livro. No primeiro capítulo investigamos como a diferença feminina suscitou debates, dividiu opiniões e tornou-se objeto de conhecimento e matéria da imaginação masculina entre os séculos XVIII e XIX. A problematização do corpo feminino pela medicina não pode ser entendida fora do contexto mais amplo da produção científica a respeito das diferenças sexuais, portanto, procuramos entender como e por que as diferenças físicas observáveis entre homens e mulheres passaram a ter importância e a serem investigadas pelos cientistas, bem como o que este conhecimento sobre a alteridade feminina representou na construção social de gênero e de que forma afetou a vida das mulheres.

Entre estes saberes se constituiu a medicina da mulher, campo definido por duas especialidades voltadas para a investigação dos órgãos sexuais e a capacidade reprodutiva das mulheres: a obstetrícia e a ginecologia. O segundo capítulo trata da produção do conhecimento obstétrico e da construção das representações do corpo feminino. Partindo da discussão sobre a entrada dos médicos na cena do parto, a análise foi direcionada para os processos de constituição e legitimação da obstetrícia no século XIX, bem como para o conhecimento produzido sobre o corpo feminino e os processos da gravidez e do parto, um conhecimento com finalidade prática e disciplinar, tendo em vista o crescente papel político e moral que o médico adquiriu ao longo do século XIX.

Analisamos a constituição da ginecologia e a representação hiperssexualizada do corpo feminino no terceiro capítulo. Definida pelos médicos como a ciência da mulher, a ginecologia contribuiu 
significativamente para a divulgação de uma imagem extremamente ambígua da mesma, marcada, por um lado, pela fragilidade e pela falta e, por outro, pela dissimulação e pelo excesso. Quase meio século antes da psicanálise, a ginecologia procurou responder à pergunta sobre a natureza feminina onde acreditava estar a resposta: no sexo.

A questão imediata a esta delimitação de especialidades médicas sobre o corpo feminino é a definição de mulher que dela resulta e o impacto de suas definições e restrições na vida e na auto-representação das mulheres. Nossa intenção foi desvendar o papel cultural da obstetrícia e da ginecologia na definição oitocentista da mulher, entender o seu vocabulário, suas práticas e a força de suas verdades.

Os capítulos 4, 5 e 6 referem-se à medicina da mulher no Brasil. Procuramos entender como os médicos brasileiros se posicionaram no debate a respeito da natureza feminina, as questões que os mobilizaram, procurando acompanhar as linhas de continuidade com a produção estrangeira analisada nos capítulos anteriores e as particularidades deste saber no meio médico brasileiro. No quarto capítulo, tratamos da constituição das duas especialidades no Brasil, recuperando, primeiramente, as condições de organização do ensino médico e o estatuto da obstetrícia e das doenças das mulheres. Em seguida, utilizando as teses médicas dos doutorandos das Faculdades de Medicina do Rio de Janeiro e da Bahia, enfocamos a produção de conhecimentos sobre o corpo feminino.

A prática médica, os temas polêmicos, a formação da clientela e a definição das competências profissionais são objeto do quinto capítulo. Um aspecto importante da prática da medicina da mulher foi a questão da existência de espaços hospitalares específicos para o atendimento das mulheres, que acabou resultando na construção das primeiras maternidades no Brasil. A documentação destas instituições, composta por registros de entrada e saída de pacientes, embora esparsa e lacunar, oferece um quadro a respeito do perfil social e racial das primeiras mulheres que foram atendidas nas maternidades e nas enfermarias obstétricas, bem como são documentos que testemunham a aplicação dos princípios teóricos da medicina da mulher no Brasil.

O capítulo 6 discute a ideologia da maternidade presente nas publicações médicas brasileiras não especializadas e de outros intelectuais do século XIX, voltadas, na sua maioria, para a questão da educação feminina. Destas publicações, destacamos o pensamento de um dos 
intelectuais mais autênticos da época, Tobias Barreto. Não sendo médico, mas conhecendo o debate e os argumentos científicos, Barreto produziu um dos mais interessantes textos críticos a respeito das teorias em voga, sendo defensor da educação superior para as mulheres em uma época em que a maior parte das autoridades médicas e dos cientistas refutava esta possibilidade, pois a educação feminina devia ter apenas fins pragmáticos, destinados à formação da boa esposa e da mãe. Ainda neste capítulo analisamos o melhor exemplar do conhecimento científico sobre gênero produzido no Brasil no século XIX. Trata-se do livro A Mulher e a Sociogenia, de Tito Livio de Castro (1893). Embora escrito em uma linguagem científica, o livro era acessível para um público culto mais diversificado. Além de expor as principais formulações teóricas evolucionistas sobre o sexo e a função social da mulher, a obra é também um libelo a favor da educação feminina, pois embora seu autor acreditasse na inferioridade cerebral do sexo feminino, a crença na evolução o fazia defender a educação com fins evolutivos para a espécie.

Avessos aos discursos mais misóginos de seus colegas europeus e norteamericanos, os médicos e intelectuais brasileiros preferiram adaptar as teorias e as idéias a respeito da alteridade feminina às particularidades da realidade social e cultural brasileira, procurando, ao mesmo tempo, definir a mulher e estabelecer sua função na sociedade como formadora de homens.

A origem deste livro foi minha tese de doutorado defendida na Universidade Estadual de Campinas (Unicamp) sob a orientação de Leila Mezan Algranti, a quem agradeço pela forma segura e afetuosa com que sempre conduziu nossas relações acadêmicas, e também pela amizade que tenho o prazer de compartilhar. Com Leila aprendi muito, especialmente que as relações de orientação podem ser um proveitoso exercício não só de conhecimento, mas de interação humana.

Agradeço de forma especial a Célia Marinho de Azevedo, Edgar de Decca, Etelvina Maria Trindade e Maria Lúcia Mott, bem como ao Departamento de História da Universidade Federal do Paraná (UFPR), à Coordenação de Aperfeiçoamento de Pessoal de Nível Superior (Capes), e às instituições nas quais realizei a pesquisa nas cidades do Rio de Janeiro, Salvador e Curitiba.

A transformação de uma tese em livro é um trabalho árduo e de equipe. Agradeço à Editora Fiocruz, em especial a Jaime Benchimol e Gilberto Hochman, João Carlos Canossa, Janaina de Souza Silva, Cíntia Bravo de 
Souza e Guilherme Ashton Nunes, pela forma profissional e carinhosa com que leram os originais e pelo acolhimento do livro.

Aos meus amigos, às minhas amigas e aos meus familiares agradeço pela incansável disposição de me acolher nos bons e nos maus momentos e pelo apoio incondicional que sempre recebi, principalmente agora pela publicação. 


\section{Gênero, Ciêncía e cultura}

Nomear e classificar têm sido tarefas fundamentais da ciência moderna, uma forma de conhecimento da Natureza e dos seres humanos cuja história é narrada como resultado de uma revolução na forma de ver e explicar o mundo. Os alicerces do conhecimento científico moderno foram fundados em centros culturais europeus renovados com o ímpeto humanista, especialmente na Itália, onde as universidades passaram a fornecer novos modelos e métodos de investigação a respeito da Natureza e dos seres humanos.

No que diz respeito à medicina, mesmo nos quadros dos dogmas cristãos, desenvolveu-se um conhecimento fundamentado na observação direta, no empirismo, numa lenta, mas implacável revelação dos segredos do corpo humano, exposto no teatro das dissecações (Delumeau, 1994). Embora não se possa falar ainda de uma ciência experimental, os intelectuais renascentistas deram os primeiros e decisivos passos em direção ao conhecimento da Natureza, procurando estabelecer uma nova e mais atuante participação do espírito humano na compreensão da ordem do universo regido pelos desígnios de Deus.

Essa atitude humanista, pragmática e crescentemente racionalista, foi o fermento dos estudos realizados ao longo dos séculos XVI e XVII, bem como dos enfrentamentos filosóficos entre aristotélicos e copernicianos; entre visões finitas e hierárquicas do universo e as idéias de movimento, infinitude e leis naturais. O pensamento filosófico e científico que se estruturou a partir de então, não apenas começava a decifrar a linguagem matemática do mundo físico e a conhecer suas regularidades, mas a conceber o conhecimento como um processo objetivo fundado no princípio da 
separação entre o observador e a realidade. Acompanham este princípio de natureza dualista outras dicotomias igualmente importantes para a produção do conhecimento científico como natureza/cultura, emoção/razão, particular/universal, corpo/mente, todas fortemente marcadas por valores culturais, conforme explica Keller (1985).

Ao analisar os discursos de Francis Bacon, a autora ressalta como sua visão a respeito da ciência envolvia necessariamente poder, domínio e controle do homem sobre a Natureza, sendo a ciência o meio pelo qual a ambição humana pelo poder encontraria seu melhor e mais nobre emprego. Dessa forma, um dos significados das dicotomias do pensamento científico é o exercício do poder e a dominação de um dos pares sobre o outro.

Seguindo esta mesma linha de argumentação crítica, Wilshire (1997) explica que a lista dessas dicotomias é bastante antiga - remontando ao tempo de Aristóteles - e que um dos seus mais fortes significados é aquele associado ao gênero. Para entendermos melhor esta leitura feminista da epistemologia científica, tomemos uma das mais significativas dicotomias produzidas por este tipo de conhecimento: natureza/cultura. Neste par, a Natureza é simbolicamente associada à feminilidade, representada pela figura feminina tanto nos textos quanto nas alegorias. A melhor descrição deste simbolismo foi elaborada por Francis Bacon, num texto publicado entre 1602 e 1603, com o sugestivo título The Masculine Birth of Time: "Minha intenção é de comunicar a você não fantasias de meu cérebro, nem sombras provocadas pelas palavras, nem um rescaldo religioso. Não: alcancei a própria verdade levando a você a Natureza com todos os seus filhos para pô-la a seus serviços e fazer dela a sua escrava" (Bacon apud Martensen, 1998: 146). ${ }^{1}$

Para Bacon, a ciência era uma atividade masculina, pois, no homem, acreditava-se predominar a mente ou o intelecto, sede da razão, a única faculdade mental que o levaria a conhecer e a dominar a Natureza em uma infinita transcendência de si mesmo na produção da cultura e da civilização. Bacon descrevia o conhecimento da Natureza usando o vocabulário das relações de gênero de sua época: uma questão de domínio do mais forte sobre o mais fraco; de soberania masculina e de subordinação feminina. A Natureza deveria ser conhecida na sua verdade para servir ao homem, ser sua 'escrava', o autor utilizava-se do vocabulário da dominação para melhor representar a relação que ele imaginava ser análoga ao conhecimento da Natureza.

De acordo com Keller (1985), as idéias de Bacon e de outros eminentes representantes do pensamento científico moderno são reveladoras de como 
as associações de gênero estão presentes na formulação da linguagem científica, não como ornamentos ou recursos estilísticos, mas como elementos formadores da estrutura ideológica das ciências com implicações práticas, conforme pretendemos demonstrar neste capítulo.

Tomando como referência a bibliografia feminista que nas últimas três décadas vem fazendo uma revisão crítica dos paradigmas científicos ao questionar sua suposta neutralidade e objetividade, procuraremos, neste capítulo, analisar como as diferenças humanas percebidas e construídas culturalmente são ressignificadas em domínios culturais que não precisam estar necessariamente relacionados às variáveis de sexo, raça ou classe, conforme observamos na construção da dicotomia natureza/cultura.

Os principais argumentos aqui expostos foram desenvolvidos também a partir de um conjunto de pesquisas sobre a história cultural do corpo, em especial os trabalhos de Laqueur (1992) e Schiebinger (1994). Para ambos, a emergência das diferenças sexuais e raciais no campo das ciências biológicas deu-se em meados do século XVIII, suplantando um modelo bastante antigo de conhecimentos sobre o corpo humano cujo princípio era a homologia sexual. Na primeira parte do capítulo, pretendemos analisar como anatomistas, fisiologistas e médicos passaram a questionar os conhecimentos sustentados na tradição aristotélico-galênica a respeito das diferenças entre homens e mulheres. Procuraremos compreender os significados do extenso inventário sobre as diferenças sexuais empreendido durante os séculos XVIII e XIX, bem como o fato significativo de que a diferença foi localizada no corpo feminino.

A segunda parte do capítulo trata da produção discursiva sobre a alteridade feminina. Se as diferenças entre os sexos eram tão irredutíveis e foram minuciosamente descritas e classificadas, cabe então questionar as conseqüências deste tipo de conhecimento para a vida das mulheres, ou seja, entender como os saberes aqui em questão produziram um novo objeto $e$, ao fazê-lo, estabeleceram os fundamentos científicos da natureza e identidade feminina.

\section{O Sexo e a Ciência Moderna}

Na segunda metade do século XIX a questão sexual era um problema que perseguia muitos homens da ciência, particularmente os médicos, esses especialistas em olhar e examinar os corpos e estabelecer as verdades sobre 
a Natureza e a identidade dos indivíduos. Apesar dos pudores vitorianos, os exames médicos tornaram-se, ao longo do século, muito detalhados, seguindo o modelo das autópsias, descendo aos detalhes mais íntimos e internos dos corpos examinados.

Saber exatamente qual o sexo verdadeiro de cada pessoa era uma preocupação relativamente recente, algo que começara a surgir na documentação médica e jurídica por volta da segunda metade do século XVIII, quando as diferenças passaram a ser observadas e utilizadas na construção do conhecimento sobre a Natureza e na organização da sociedade. ${ }^{2}$

Tendo como referência esta documentação científica, começaram a ser publicados os manuais europeus sobre sexo, amor e casamento, produzidos tanto por autores conservadores quanto por liberais - alcançando vendagens astronômicas para a época em que foram publicados, sendo alguns deles verdadeiros campeões de vendas - que contribuíram para a educação sexual de homens e mulheres do século XIX. ${ }^{3}$ Um desses escritores foi o médico francês Auguste Debay, autor de um best seller sobre o casamento, publicado em 1850. Posteriormente, Debay (1901) escreveu outro manual, desta vez voltado para a vida sexual, cujo título é Hygiene e Physiologia do Amor nos Dois Sexos. Escrito numa linguagem acessível, o livro reproduziu várias idéias científicas da época a respeito da natureza nervosa e quase patológica do sexo feminino, embora exaltasse as qualidades morais e defendesse o poder civilizador das mulheres. Debay se dizia um admirador e um adepto do culto à mulher, numa linha muito próxima a de Michelet, seu compatriota, como veremos.

Apesar do título, boa parte do livro diz respeito à fisiologia, ao corpo e ao comportamento sexual feminino, à higiene e aos conselhos do Dr. Debay para que a vida sexual dos casados fosse saudável, sem excessos e desacordos. ${ }^{4}$ $\mathrm{Na}$ parte relativa às anomalias sexuais, o livro traz considerações a respeito de um tema que vinha sendo bastante discutido nos meios científico e médico: o hermafroditismo. Debay parte da clássica definição da presença dos dois sexos num só corpo. Antes de tudo, como um bom médico do século XIX, o autor desqualificou as definições e os relatos acerca do assunto produzidos na Antigüidade, quando "reinava a mais profunda ignorância a respeito das ciências naturais" (Debay, 1901: 240). Se Debay parece um pouco indulgente com alguns textos antigos, guarda todo seu opróbrio para a Idade Média, "época nefasta das fogueiras e do veneno" (1901: 243) na qual imperava a mais completa ignorância e truculência sobre o hermafrodita, referindo-se à condenação à morte nas fogueiras, o mesmo castigo infligido às feiticeiras. 
A verdade sobre o hermafroditismo só foi alcançada, segundo o autor, no século XIX, graças aos estudos anatomofisiológicos e embriológicos produzidos pelos cientistas e médicos que desvendaram os segredos da anatomia de indivíduos até então descritos como exemplares de fatos curiosos da Natureza.

Esses indivíduos são razoavelmente abundantes na literatura médica entre o final do século XVIII e o século XIX. Debay narra vários casos de indivíduos que tiveram seu verdadeiro sexo descoberto por médicos que transformaram seus nomes e vidas. $\mathrm{O}$ autor utiliza os relatos que compilou de tratados de fisiologia e de medicina legal para defender a idéia científica que já vinha sendo formulada há algum tempo: não havia hermafroditismo humano completo, ou seja, cada corpo tinha um e somente um único sexo.

Debay explica que graças ao trabalho de anatomistas, fisiologistas, zoólogos e botânicos se sabia que o hermafroditismo completo ocorria somente em algumas espécies de plantas e em alguns animais invertebrados. Entre os seres humanos só havia pseudo-hermafroditas masculinos e femininos. Mesmo não citando suas fontes, o médico fornece algumas indicações de fisiologistas e cirurgiões e cita com muita deferência um dos mais respeitados naturalistas franceses do século XIX que também escreveu sobre o hermafroditismo: Isidore Geoffroy Saint-Hilaire.

Saint-Hilaire era médico e filho do também famoso naturalista Etienne Geoffroy Saint-Hilaire, fundador do Instituto de Ciências e Artes do Cairo e professor de zoologia da Sorbone em 1809. Isidore Saint-Hilaire seguiu os mesmos passos do pai, sendo seu substituto no Museu de História Natural e igualmente professor de zoologia na Sorbone. Seu pai havia escrito um livro sobre monstruosidades em 1822, Philosophie Anatomique, mas foi o filho quem ficou famoso pelos estudos que fez a respeito das anomalias anatomofisiológicas nos animais e nos seres humanos, publicando sua obra mais célebre em 1837, Histoire des Annomalies de l'Organisation chez l'Homme et les Animaux.

Ao estudar as monstruosidades, utilizando-se dos métodos experimentais cada vez mais elaborados na fisiologia e na anatomia comparada, Isidore Saint-Hilaire procurou dar uma explicação natural para coisas, que pareciam, à primeira vista, aberrantes ou sobrenaturais, como animais de duas cabeças ou o hermafroditismo, por exemplo. ${ }^{5}$ Quando afirma categoricamente que a Natureza por si só não produzia monstros, SaintHilaire e seus contemporâneos estavam dizendo que os casos teratológicos 
eram resultado de obstáculos e circunstâncias acidentais que mudavam o curso da Natureza. Portanto, só os estudos embriológicos poderiam explicar que obstáculos eram responsáveis pela formação dos hermafroditas.

Fazendo experiências em ovos de pássaros, Isidore Saint-Hilaire chegou a produzir anomalias, concluindo que as perversões e os vícios de forma eram resultado de problemas ocorridos após a fecundação, afetando a formação do embrião. Assim, os hermafroditas não eram seres mitológicos, nem demônios, nem aberrações, mas anomalias resultantes de problemas ocorridos na gravidez e não na Natureza, como concluíram Saint-Hilaire, o filho, e seus leitores, entre eles Debay.

A preocupação em estabelecer o sexo verdadeiro dos pseudohermafroditas, baseada nas evidências colocadas pelas ciências biológicas experimentais do século XIX, faz parte de um enredo no qual médicos como Saint-Hilaire e Debay tiveram papel fundamental, uma vez que a questão da identidade sexual era vista como determinante e determinadora na vida das pessoas.

Como bem explicou Foucault (1982), com as novas teorias da sexualidade, as concepções jurídicas modernas do indivíduo e as formas de controle administrativo do Estado, já não mais se admitia a existência de dois sexos no mesmo corpo e nem sequer a possibilidade de escolha do indivíduo por um ou outro sexo. A última palavra cabia ao perito: era ele quem tinha o conhecimento e a autoridade para dizer qual era, afinal, o sexo da pessoa por ele examinada, independente de sua vontade e escolha.

A discussão sobre o hermafroditismo lança algumas luzes sobre o significado do debate científico em torno do sexo e das diferenças sexuais que teve início por volta da metade do século XVIII nos principais centros de produção intelectual e científica da Europa. Homens como Isidore SaintHilaire e seus colegas naturalistas faziam parte de uma tradição científica na qual o sexo passou a ser uma categoria ontológica, a designar diferenças naturais entre plantas, animais e seres humanos. Para entender como o sexo passou a ser um princípio organizador dos seres vivos, será necessário recuarmos para o período anterior ao Iluminismo, para uma época em que o sexo era um epifenômeno e as palavras e imagens não tinham uma relação de representação com as coisas.

Segundo Laqueur (1992), até a época da constituição da ciência biológica predominava um modelo teórico sobre o corpo humano no qual o que hoje chamamos de diferença sexual era percebido em termos hierárquicos 
e explicado por princípios cósmicos. É o que o autor chama de modelo do sexo único ou das homologias sexuais. As origens deste modelo estão nos escritos de Aristóteles e principalmente nos de Galeno, cuja influência na medicina foi marcante até a Revolução Científica no século XVII.

Para Galeno, os corpos feminino e masculino eram a expressão de uma ordem natural e hierárquica que organizava o cosmos e o mundo dos seres vivos. Em seus textos e nos de Aristóteles, os seres humanos ocupavam o topo da grande cadeia dos seres vivos, baseada no princípio do calor vital. Aristóteles havia estabelecido uma organização hierárquica dos fluídos fundamentada no calor e Galeno reproduziu esta antiga teoria de que os seres quentes e vivos eram mais perfeitos. ${ }^{6}$

A interpretação dada por Aristóteles e depois por Galeno é que no ápice da cadeia dos seres vivos estava o homem, por sua natureza quente e seca, seguido da mulher, hierarquicamente inferior por ser considerada mais fria e úmida. Neste pensamento, cuja vitalidade é assombrosa, o que diferenciava o homem da mulher não eram as características sexuais do corpo, mas uma noção de perfeição baseada no calor vital. O corpo feminino era a expressão da imperfeição porque seus órgãos sexuais eram invertidos, por não ter calor suficiente para exteriorizá-los como o homem. Assim, foi construída uma poderosa imagem do corpo feminino que perdurou até mesmo no século XIX, época do predomínio das idéias sobre as diferenças radicais entre os sexos: é a imagem da mulher imperfeita - a versão imperfeita do homem, tomado como medida e padrão da perfeição humana e de todos os seres vivos. ${ }^{7}$

De acordo com a análise que Laqueur (1992) faz desse modelo só havia um sexo, o masculino, e as diferenças que realmente contavam nas relações sociais entre homens e mulheres eram as diferenças de gênero. Os corpos não eram determinantes, mas ilustrativos, expressões de princípios cósmicos que dividiam coisas e seres em masculinos e femininos. ${ }^{8}$

Um bom exemplo da predominância do sexo único é o vocabulário antigo utilizado para referir-se aos órgãos sexuais. Como tudo que havia no corpo do homem havia no corpo da mulher, seus órgãos sexuais eram denominados da mesma forma que os órgãos sexuais masculinos. A vagina era um pênis invertido, os ovários eram os testículos femininos e, com algumas variações, até o útero era entendido como uma versão interior dos testículos. Esta aparente despreocupação em nomear as coisas se explica tendo em vista a ausência de interesse por parte dos médicos e filósofos 
antigos pelo que nós consideramos importante na diferenciação sexual: diferenças físicas observáveis. Para homens como Aristóteles, o que contava era a diferença entre ser ativo e passivo, ser quente e frio; ou seja, as diferenças entre homens e mulheres na vida social não tinham justificativas na natureza ou no sexo, ao contrário, seus corpos é que eram vistos como expressões de uma realidade estável na qual o elemento masculino era dominante e tomado como medida para todas as coisas.

Esse modelo atravessou os séculos e, mesmo com a renovação dos estudos anatômicos no Renascimento, as diferenças sexuais continuaram a ser vistas a partir das analogias. A ausência de vocabulário próprio para os órgãos genitais femininos perdurou ainda nos manuais de anatomia, apesar das observações mais detalhadas resultantes das dissecações. A continuidade do modelo do sexo único, em uma época em que a verdade sobre o homem não estava mais associada somente à tradição escrita, mas ao corpo aberto no teatro da dissecação, não deve ser entendida em termos de ignorância ou de misoginia, embora ambas existissem e exercessem seu papel. Havia, por um lado, dificuldades políticas e doutrinárias enfrentadas pelos mestres anatomistas. Na mesma época em que a anatomia começava a conhecer maior desenvolvimento nas universidades italianas, desde o Quatrocentto, a Igreja continuava a exercer um controle muito rígido sobre a produção do conhecimento e a prática da medicina. As dissecações eram proibidas desde a Antigüidade, durante a Idade Média e o início do Renascimento, as interdições papais com respeito ao uso dos cadáveres eram dificilmente contornadas, fazendo com que os anatomistas recorressem a práticas escusas para obter seus objetos de estudo. ${ }^{9}$ Outra dificuldade encontrada é que os corpos legalmente disponíveis eram, na sua maioria, do sexo masculino. Com algumas exceções, os corpos dos sentenciados à morte podiam ser dissecados e, como geralmente um número maior de homens era executado, a disponibilidade de dissecar corpos masculinos sempre fora maior. ${ }^{10}$

Apesar dessas dificuldades, elas por si só não explicam por que os anatomistas continuavam presos aos modelos do sexo único mesmo observando as diferenças entre os sexos na prática da dissecação. A explicação para tal descompasso entre o que era visto e o que era representado nos textos e nas ilustrações está na política cultural da representação, na relação entre representação e realidade.

O fato de os órgãos sexuais femininos continuarem sem denominação específica e serem definidos a partir da analogia com os órgãos masculinos 
indica que, para os anatomistas do século XVI, a realidade dos órgãos e a materialidade do corpo estavam ancoradas em um esquema mental, em um sistema conceitual preexistente: o modelo das homologias sexuais. De acordo com Laqueur (1992: 66), a história da anatomia renascentista

\begin{abstract}
sugere que a representação do homem e da mulher é dependente da política cultural da representação e da ilusão e não da evidência de órgãos e vasos sangüíneos. Nenhuma imagem verbal ou visual dos fatos da diferença sexual existe independente das exigências sobre o significado de tais distinções.
\end{abstract}

Portanto, por mais que os anatomistas vissem as diferenças, elas não tinham significado. É por isso que até o século XIX alguns órgãos sexuais femininos continuaram a ter a mesma denominação dos órgãos masculinos e, no caso dos hermafroditas, aceitava-se a escolha do indivíduo, já que era o corpo que precisava adequar-se ao comportamento, ou, em outros termos, o sexo ao gênero, e não como passou a ser na época de Debay, quando o sexo tornou-se determinante do comportamento. ${ }^{11}$

As representações anatômicas da diferença sexual indicam que um conhecimento novo como a anatomia seiscentista, baseada no olhar, utilizava esquemas mentais ou modelos representativos antigos para tornar o que era novo reconhecível, familiar. Um excelente exemplo da dinâmica dessas representações anatômicas são as ilustrações do corpo feminino. Entre os médicos e filósofos da época de Vesalius e Matteo Colombo prevalecia a idéia da imperfeição ou da incompletude do corpo feminino. Diante de uma estrutura anatômica nova como, por exemplo, o clitóris, os anatomistas utilizaram o seu esquema conceitual para representá-lo. Este novo e desconhecido órgão foi visto como um pênis, uma estrutura análoga ao modelo anatômico do corpo masculino. ${ }^{12}$

De acordo com Gombrich (1986), as representações pictóricas são indicativos de que não há um olhar puro sobre a realidade, ela é observada através de lentes ou esquemas conceituais. Portanto, as representações de formas desconhecidas obedecem sempre a um desejo de conformar e de assimilar a forma nova aos esquemas ou modelos de quem vai descrevê-la ou representá-la. ${ }^{13}$

Segundo essa análise, pode-se concluir que a anatomia nada mais fez do que reiterar a idéia da supremacia do homem, tomando-o como modelo da estrutura do corpo humano e tratando a diferença sexual em termos de imperfeição. As representações anatômicas da época demonstram como havia poucas ou tênues relações entre anatomia e sexo, sendo estas 
um conhecimento informado e conformado pela força das idéias e das convenções sociais de gênero e não pelos fatos da biologia.

O modelo de conhecimento sobre o corpo fundado no gênero e não no sexo foi gradativamente substituído pelo novo modelo das diferenças sexuais que começou a ser formulado no início do século XVIII, quando o corpo passou a ser um novo campo de redefinição das relações de gênero e a ciência voltou-se para a Natureza em busca das explicações a respeito das diferenças humanas.

Para a filosofia e o pensamento político liberal, as bases para a organização política e o estabelecimento dos mores estava na Natureza, só que esta era entendida como um princípio de dupla face. Se, por um lado, a filosofia defendia a dignidade natural dos seres humanos, sustentando os argumentos em favor da liberdade e da igualdade; por outro, utilizava-se das mesmas leis naturais para justificar as desigualdades sociais ao afirmar que a Natureza não era uniforme e que a existência de diferenças naturais entre os seres humanos podia explicar o motivo pelos quais alguns eram mais aptos a assumir responsabilidades, a explicar as coisas e a comandar, enquanto outros, por um impedimento natural, estavam destinados a obedecer, a serem explicados e a se subordinarem. É, portanto, no interior desta formulação filosófica a respeito da natureza humana que as investigações científicas sobre o sexo e a raça passaram a ser realizadas com maior constância e a adquirir um caráter profundamente ideológico. ${ }^{14}$

Evidentemente, o materialismo científico e o ceticismo foram fundamentais na formulação de conhecimentos a respeito das diferenças humanas. Contudo, estas tornaram-se visíveis porque adquiriram um significado político; ou seja, o que aqui se defende é que não se pode atribuir ao progresso da ciência a 'descoberta' das diferenças humanas, ao contrário, tais diferenças foram produzidas no interior dos embates políticos, dos enfrentamentos de problemas de ordem social e política para os quais a solução foi procurada na Natureza.

A mudança de enfoque das diferenças hierárquicas entre homens e mulheres para as diferenças físicas irredutíveis - que assumiram, por sua vez, significados políticos importantes na reorganização das relações de gênero - foi contemporânea aos debates que envolveram homens e mulheres intelectualizados dos séculos XVII e XVIII a respeito dos direitos civis das mulheres.

Para os intelectuais que defendiam a causa das mulheres, as desigualdades se originavam na própria sociedade, na falta de oportunidades 
iguais para ambos os sexos. Já para os intelectuais que procuravam justificar a ordem social fundada nas desigualdades de gênero, a questão não se colocava na sociedade, mas nas leis inexoráveis da Natureza: as mulheres eram inferiores aos homens porque eram menores, mais frágeis, mais sensíveis e mais sujeitas aos imperativos da sua natureza sexual. Homens e mulheres eram, segundo esta interpretação, radicalmente diferentes em sua constituição física e intelectual, e esta diferença era irredutível - estava inscrita nos corpos, ou seja, nos corpos sexuados de homens e mulheres. ${ }^{15}$

Como bem expressou Badinter (1985: 10), "a diferença não convive bem com a igualdade" e, nesse sentido, os cientistas deram sua contribuição ao debate, procurando e classificando as diferenças sexuais, sendo os primeiros a sustentar empiricamente a 'natural' relação entre o sexo feminino, sua inferioridade biológica e sua subordinação política.

Ser homem e ser mulher passou a ser uma determinação física, uma realidade comandada pela diferença dos corpos. A diferença já não era restrita aos órgãos sexuais e mesmo estes passaram a ser vistos e descritos como completamente diferentes. Após a segunda metade do século XVIII, o vocabulário começou a ser específico para os órgãos genitais masculinos e femininos, embora ainda perdurasse o vocabulário da homologia sexual no discurso médico até o final do século XIX. A partir de então, as ciências biológicas, encabeçadas pela anatomia e a fisiologia, lançaram-se na busca das diferenças sexuais que deviam fundamentar e justificar as desigualdades de gênero na vida pública e privada.

Durante os séculos XVIII e XIX houve uma grande produção científica a respeito do sexo. Percorreu-se cada detalhe com a finalidade de encontrar as evidências da diferença sexual, demonstrando a especificidade do corpo feminino, tido então como o corpo diferente. O método era comparativo. Para cada órgão, os anatomistas estabeleciam comparações de tamanho, forma, volume e peso, entre homens e mulheres, porque o sexo não estava restrito aos órgãos sexuais, mas penetrava cada osso, nervo, músculo, veia e órgão dos corpos.

A anatomia setecentista forneceu o modelo de investigação para a ciência sexual. As primeiras ilustrações anatômicas do esqueleto feminino apareceram na década de 1730. Embora os anatomistas estivessem preocupados com a exatidão de suas observações, os esqueletos femininos eram desenhados a partir de uma convenção, de um conceito de feminilidade 
que informava o cientista. As representações do esqueleto feminino produzidas nessa época e no início do século XIX eram objetivações, isto é, materializações dos conceitos de feminilidade, como a fragilidade física, a beleza e a delicadeza na figura de esqueletos com crânios pequenos, ossos mais finos e pélvis bastante largas, para evidenciar a 'natural' função da mulher: a maternidade.

Os fisiologistas não se furtaram ao debate. Com o desenvolvimento da química, passaram a medir o volume de gases consumidos pelos corpos e a quantidade de elementos químicos presentes no sangue, sempre estabelecendo comparações; a feminilidade estaria associada à falta de um elemento químico considerado importante ou ao excesso de outro que seria indicativo de fragilidade ou inferioridade física. A diferença sexual não era encontrada somente na estrutura física, mas também na química do corpo (Schiebinger, 1987).

Contudo, o sexo como categoria da diferença não teve seu uso restrito às investigações sobre o corpo humano, passou a ser também um princípio organizador da natureza dos outros seres vivos. A botânica e a zoologia do século XVIII igualmente se utilizavam do mesmo esquema conceitual das diferenças sexuais para classificar plantas e animais, elegendo o sexo ou certas características sexuais para inventariar os seres vivos e estabelecer seu lugar em uma ordem natural. ${ }^{16}$

Para onde olhavam, os homens da ciência do século XVIII só viam um avolumar-se de diferenças, fosse entre os minerais, fosse entre as plantas e os animais, fosse entre os seres humanos. Entre estes, a nova ciência biológica do sexo mostrava como homens e mulheres eram diferentes e como as diferenças físicas e até mesmo químicas eram determinantes na vida social de ambos. Fortalecia-se a conviç̧ão de que à forma correspondia a função, só que este princípio anatomofisiológico, ao ser ressignificado socialmente, estabelecia uma relação indelével entre o corpo e os papéis sociais. No entanto, as diferenças humanas não se restringiam ao sexo. Na mesma época, os naturalistas davam os primeiros passos para explicar as diferenças raciais, constituia-se um outro conjunto de discursos científicos voltados para a questão da variação humana.

A unidade humana foi a base da formulação dos discursos a respeito da diferença entre animais e seres humanos. Bipedalismo, linguagem e a faculdade da razão eram características exclusivas dos seres humanos e passaram a ser interpretadas como um sinal da superioridade em relação aos animais. Os discursos científicos tiveram, ao formular teorias sobre 
as diferenças raciais, o importante papel de justificar as práticas de dominação existentes.

O racialismo parte da constatação de que os grupos humanos são diferenciados fisicamente; assim como nas espécies animais, havia características físicas distintas nos humanos, como nas raças. A princípio, as diferenças físicas eram apenas um dado, só que, para os naturalistas, presos ao materialismo e ao determinismo, o físico tinha uma relação fundamental com a moral, uma relação de determinação, como havia entre sexo e gênero. Como corolário desse materialismo, definiu-se uma escala de valores em que as diferenças raciais estavam organizadas, ou melhor, classificadas hierarquicamente a partir da seleção de certas características físicas e culturais, como a cor da pele, os cabelos, a forma física, os costumes e a organização política.

Para os filósofos e naturalistas, a classificação das raças humanas obedecia ao critério da comparação, para o qual o homem branco europeu era tomado, a priori, como a norma e a medida do desenvolvimento humano, assim como a cultura européia era considerada a máxima expressão da civilização. Dessa forma, há que se concordar com Todorov (1993) quando ele diz que, nesse contexto, toda a diferença é sentida como falha. Assim, o naturalista forneceu argumentos irrefutáveis para práticas políticas de dominação, como a discussão em torno da legitimidade da escravidão ou a idéia de que alguns povos não eram desenvolvidos suficientemente para conduzir suas vidas e precisavam ser guiados pelos 'civilizados' ${ }^{17}$

No amplo empreendimento intelectual de inventariar as diferenças humanas, a ciência sexual e a ciência racial compartilharam dos mesmos princípios, utilizaram os mesmos métodos e chegaram a conclusões muito semelhantes, tanto que, freqüentemente, usavam o recurso narrativo da analogia, empregando metáforas sexuais e raciais, para fazer referência aos seus respectivos objetos. Sexo e raça passaram a ser categorias biológicas cada vez mais inter-relacionadas no discurso científico do final do século XVIII em diante, numa nítida resposta da comunidade científica às pressões sociopolíticas colocadas pela questão das desigualdades de gênero e pelo colonialismo. Conforme Pierucci (1999), o final do século XVIII foi pródigo na produção das diferenças, especialmente por parte do discurso de intelectuais conservadores. Procede-se, portanto, inventariando as diferenças para, posteriormente, nos embates políticos, rejeitá-las no interior de formulações discursivas sexistas e racistas. 
Um campo privilegiado da ciência biológica que nos ajuda a entender como sexo e raça passaram a ser análogos é a anatomia. Vesalius já havia trabalhado com a anatomia comparada no seu livro de 1543, fazendo um estudo dos crânios de cinco raças humanas; ${ }^{18}$ cirurgiões e viajantes traziam vários relatos dos povos exóticos dos confins do mundo; os europeus dos séculos XVI e XVII já tinham contato com africanos e indígenas do Novo Mundo, sendo alguns deles levados para as cidades européias e transformados em verdadeiras peças de coleções dos naturalistas, como o eram as plantas e os animais exóticos. ${ }^{19}$ Portanto, no início do século XVIII já havia um corpo razoável de conhecimentos anatômicos a respeito das diferentes raças humanas a partir do qual os anatomistas desenvolveram seus estudos.

Ante uma considerável massa de informações, os anatomistas organizaram os dados disponíveis para estabelecer quais as diferenças físicas que realmente eram importantes; quais estruturas eram fundamentais na diferenciação entre as raças humanas. Há uma grande variedade de estruturas passíveis de comparação, como a presença de barba nos homens e a beleza física nas mulheres, por exemplo, mas os anatomistas escolheram o esqueleto como a estrutura mais importante na diferenciação racial.

Da mesma forma que viam no esqueleto os sinais da diferença sexual, representando o esqueleto pequeno e frágil das mulheres em oposição ao esqueleto grande e forte dos homens, os anatomistas também encontraram os sinais das diferenças raciais, especialmente no crânio. Em 1786, Petrus Camper escreveu uma dissertação dizendo que pelo tamanho do crânio podia-se entender as diferenças entre brancos e negros e as proximidades anatômicas entre estes e os símios. ${ }^{20}$ Camper e outros craniologistas acreditavam, como bons materialistas que eram, que o tamanho do crânio tinha relação direta com o grau de inteligência, já que o crânio alojava o cérebro e este era considerado a sede da razão.

Schiebinger (1994) explica que os craniologistas usaram as medidas cranianas de indivíduos do sexo masculino para fundamentar suas teorias raciais porque a razão era considerada um atributo masculino. Isso explicaria o motivo pelo qual os estudos racialistas, na sua maioria, faziam comparações entre os homens de raças diferentes, sendo pouco comuns as comparações raciais entre as mulheres. Estas existiram só a partir de 1830 e em um número pequeno, mas nunca tiveram a importância que as comparações dos crânios alcançaram no discurso racialista. Geralmente, quando as comparações raciais entre as mulheres eram feitas, a observação 
recaía sobre estruturas e características associadas à sexualidade, como os seios, o desejo sexual mais ou menos acentuado, o tamanho do clitóris e, principalmente, o tamanho da pélvis.

São poucos os exemplares destas comparações sexo-raciais e quando vinham a público era para reforçar estereótipos, como a lascívia e a perversão das mulheres negras, como ilustra muito bem o caso de Sarah Bartmann, uma jovem mulher hotentote, que, 'descoberta' por um naturalista, foi levada a Europa, exposta como um espécime das raças negras e, por fim, após sua morte, dissecada por um dos mais eminentes cientistas da época, Curvier:

A memória escrita por Curvier sobre Sarah Bartmann revela a dinâmica de raça e gênero na ciência do início do século XIX. Seu interesse pelo corpo desta mulher sul-africana centralizou-se na sexualidade; nove das dezoito páginas são reservadas à genitália de Bartmann, aos seios, às nádegas e à pélvis. Só um breve parágrafo a respeito de seu cérebro. Nos dois relatos de sua raça e de seu sexo - Bartmann foi relegada ao mundo brutal da carne. (Schiebinger, 1994: 172)

A pélvis feminina representou, para o discurso racialista, o mesmo papel que o crânio masculino teve nas comparações entre brancos e negros. Acompanhando as transformações ideológicas a respeito da mulher e a crescente invasão dos médicos em domínios até então exclusivos das mulheres, como a obstetrícia e as doenças femininas, os anatomistas escolheram a pélvis como o índice anatômico da feminilidade. Esta divisão de gênero atravessava a anatomia racial, ao estabelecer no corpo as estruturas masculinas e femininas que seriam indicativas das diferenças raciais. ${ }^{21}$

Embora homens negros e mulheres brancas européias fossem muito bem diferenciados culturalmente, quando pensados como categorias biológicas, as similaridades entre estes dois grupos se acentuavam e eles passavam a interagir no conhecimento novo que era produzido. É assim que se pode entender como as mulheres foram comparadas aos negros a partir do tamanho do crânio, ou como os negros foram considerados representantes de raças do tipo 'feminino', porque eram entendidos como menos racionais e mais emotivos.

Exemplos como estes mostram como funcionou a dinâmica do gênero e da raça na formulação do conhecimento científico sobre as diferenças humanas. Partindo do princípio de uma hierarquia natural baseada no desenvolvimento físico, o sexo e a raça passaram a ser medidos, pesados e comparados tendo como padrão de normalidade o corpo do homem branco 
europeu. Como todos os índices sexuais e raciais eram inferiores àqueles do padrão, concluiu-se que mulheres e homens de cor negra e mulheres brancas eram, apesar das diferenças culturais e raciais, 'naturalmente' inferiores e imaturos; justificou-se, assim, a manutenção das desigualdades sociais e a legitimação do poder no interior da sociedade européia, inclusive nas relações coloniais.

No século XIX, os estudos sobre sexo e raça se intensificaram e ocuparam boa parte dos interesses dos pesquisadores. Craniologistas, patologistas e anatomistas continuaram suas investigações sobre as raças, procurando sempre por um indício mais indelével e confirmador das hierarquias raciais. Em contrapartida, médicos e cientistas não cessaram suas buscas a respeito das diferenças sexuais, especialmente a respeito das diferenças do corpo feminino, cada vez mais percebido e representado como o corpo diferente, formulando o conhecimento necessário para subsidiar outros discursos igualmente interessados na mulher e na sua diferença.

\section{A Alteridade Feminina: ciência e cultura nos séculos XVIII e XIX}

A produção historiográfica relativa à história das mulheres e da sexualidade mostra como a mulher e a sua sexualidade foram objeto de uma vasta produção discursiva entre os séculos XVIII e XIX. As fontes são muito diversificadas, mas um grande número delas revela a preocupação dos cientistas e dos homens cultos da época em entender a especificidade feminina, ou melhor dizendo, a natureza da mulher, para formular seus discursos a respeito das relações sociais entre homens e mulheres, definindo seus lugares e estabelecendo seus papéis. ${ }^{22}$

Embora o interesse pela mulher e sua diferença sexual crescesse e chamasse a atenção de um público letrado diversificado, os médicos desempenharam um papel de destaque nessa reflexão. Especialmente no século XIX, foram inúmeras as publicações médicas sobre o corpo feminino que procuravam explicar a singularidade de sua anatomia e fisiologia, prescrever condutas por meio da higiene e classificar as doenças que lhe eram específicas, indicando as respectivas terapias. Multiplicaram-se os tratados e manuais médicos sobre a natureza feminina, alguns alcançando mais de 30 edições, demonstrando uma incrível continuidade de idéias e práticas médicas. Ao longo do século XIX este interesse se intensificou até constituir-se um campo específico da medicina especializado na mulher: a ginecologia. ${ }^{23}$ 
É também nesse período que foram produzidos estudos mais objetivos a respeito da reprodução, tanto no campo da embriologia quanto no da obstetrícia, com o desenvolvimento da anatomia patológica e da prática de autópsias em mulheres grávidas ou em natimortos. Com isso, a medicina parecia estar desvendando segredos ou, na hipótese mais aceita, derrubando velhas superstições e desfazendo fantasias comuns à cultura erudita e popular associadas ao corpo feminino, como os partos monstruosos ou antinaturais e a influência da imaginação da mulher sobre a formação do feto, entre outras. ${ }^{24}$

A principal diferença entre os tratados e manuais publicados entre os séculos XVIII e XIX e aqueles produzidos em épocas anteriores encontra-se na preocupação em definir a especificidade feminina a partir de critérios objetivos fornecidos pelas ciências biológicas, como a anatomia, a fisiologia e a craniologia, estabelecendo assim, um novo discurso, mais objetivo e imparcial, distante, portanto, das superstições e da imaginação tão presente nos tratados antigos de obstetrícia, nos quais o conhecimento era muito mais teórico e confirmador de tradições do que resultado da observação guiada pelos métodos e técnicas da ciência. De acordo com Jean Pierre Peter (1981: 80),

a mulher era, para a medicina, como um território a conquistar. Além de conhecer, descobrir. Universo espantoso, desconcertante, cheio de armadilhas e surpresas. Frente às questões a respeito da natureza humana que a medicina devia colocar e esclarecer, como 'o que é o Homem', se acrescenta e se substitui por outra mais polêmica: O que é a mulher?

Para responder a esta questão, os médicos escreveram muito. Dentre eles se destaca Pierre Roussel e o seu famoso tratado Du Système Physique et Moral de la Femme, publicado em 1775, uma das mais importantes referências do final do século XVIII sobre o assunto. Roussel foi o primeiro médico iluminista a defender a especificidade da natureza feminina. Seu sistema consistia em definir o sexo, o corpo e a alma feminina como um todo homogêneo radicalmente diferente do homem. Para Roussel e seus contemporâneos, como Moreau de la Sarthe e Julian Joseph Virey, igualmente autores de livros sobre a mulher, esta tinha um papel social e uma função moral bem definidos devido à organização de sua natureza. Embora não fosse igualitário e muito menos feminista, Roussel não pode ser chamado de misógino, pois não tirou nenhuma conclusão sobre a inferioridade feminina. Sua conclusão foi o reconhecimento da diferença 
feminina em relação ao homem e, influenciado por Rousseau, estabeleceu a relação entre a especificidade do corpo feminino e a função social da maternidade.

Segundo Yvonne Knibiehler (1976), médicos como Roussel, Moreau e Virey foram representantes de um discurso de caráter mais filosófico e literário da medicina, muito influente até a época da medicina clínica e experimental da metade do século XIX. Nos textos desses médicos, a autoridade ainda repousa mais na tradição intelectual do que na observação dos fatos. No entanto, são deterministas, como se observa pelos próprios títulos de seus livros, ao defenderem a tese de que corpo e moral exerciam simpatia mútua e, no caso da mulher, estavam organizados de tal forma para cumprir a finalidade da maternidade.

A 'descoberta' das diferenças sexuais pelas ciências biológicas contribuiu para a reabilitação de um órgão exclusivo das mulheres que acabou se tornando um verdadeiro fetiche nos discursos médicos: o útero. Não mais visto como similar aos testículos, o útero ganhou um significado muito importante para os médicos iluministas. Este órgão era a prova que eles constantemente evocavam de que a Natureza não havia criado um ser imperfeito, como pensavam os antigos, mas confiado às mulheres a missão de gerar e de dar à luz; desse modo, o útero, portanto, estava intimamente associado ao papel social que os rousseauístas tanto defendiam para a mulher: ser mãe. ${ }^{25}$

Nas definições iluministas da mulher, o determinismo biológico e a centralidade do útero são partes indissociáveis. Homens como Diderot, por exemplo, contemporâneo de Roussel e de outros médicos que tanta tinta gastaram sobre o 'outro sexo', contribuíram para a divulgação da mulherútero, ao afirmar que este órgão não era apenas a 'matriz', o órgão da feminilidade, mas um verdadeiro tirano das entranhas que comandava toda a economia do corpo feminino e suas emoções. Segundo Diderot (1991), “a mulher traz dentro de si um órgão susceptível de terríveis espasmos, que dispõe dela e que suscita em sua imaginação fantasmas de todo tipo. (...) é do órgão próprio de seu sexo que partem todas as suas idéias extraordinárias".

O determinismo de Diderot estava de acordo com todo um conjunto de saberes anatômicos e fisiológicos que afirmavam estar no corpo as marcas da diferença sexual, especialmente no corpo feminino, um novo campo de significados acessível à observação meticulosa do médico-anatomista. ${ }^{26}$

Mas o útero podia ser uma fonte inesgotável de doenças. Este é o outro lado da definição iluminista da natureza feminina. O final do século XVIII inaugura a época das doenças uterinas. Não que elas não chamassem 
a atenção dos médicos antes - afinal há registros sobre as doenças uterinas desde a época de Soranos no século II -, mas passaram, doravante, a fazer parte da definição ambígua da mulher, porque ambígua era a sua natureza. Foi com o discurso iluminista sobre a importância do útero que começou a ser esboçada uma imagem da mulher que vive no limite entre a fisiologia e a patologia, entre a norma e o desvio.

O estudo das doenças uterinas consome o tempo de muitos doutores munidos do saber anatômico e imbuídos das idéias a respeito da natureza feminina, que procuraram conhecer a origem dos males da 'matriz' e a sua cura, para que a mulher desempenhasse bem o seu papel. Desde a Antigüidade os médicos procuravam responder às queixas femininas a respeito de problemas menstruais, dores abdominais e os incômodos corrimentos. A maior parte dos problemas ginecológicos era, desde os tempos de Hipócrates, associados ao útero, fosse por suas 'andanças' no corpo, causando sufocações, fosse por sua natureza nervosa e passível de agitações que podiam provocar as doenças, como a mais famosa delas, a ninfomania ou furor uterino. ${ }^{27}$

A discussão em torno da ninfomania, presente em vários textos médicos do final do século XVIII, contribuiu para a construção da definição patológica do corpo feminino que perdurou até o final do século XIX, quando o corpo da mulher, representado pelo útero, podia reagir às impressões externas, provocando estados mórbidos. Até meados do século XVIII os médicos ainda prescreviam terapias visando ao equilíbrio humoral de suas pacientes ninfômanas, mas a partir de então, apoiados na idéia de que o corpo e a moral interagiam mutuamente, as terapias associavam tratamentos localizados, como sangrias, purgantes, dietas alimentares e banhos, a tratamentos de natureza moral, proibindo leituras de romances, reuniões íntimas com amigas, para evitar conversações sobre paixões que pudessem despertar a imaginação, além de bebidas alcoólicas e alimentos muito condimentados que excitassem o sangue. ${ }^{28}$

Mas a busca das causas morais não estava restrita à ninfomania, sendo comum a etiologia moral para outros problemas ginecológicos. Até meados do século XIX os médicos ainda estavam preocupados em saber o que faziam e sentiam as suas pacientes. Bienville (1996) havia estabelecido em seu tratado sobre a ninfomania que o diagnóstico correto dependia da atenção minuciosa do médico não somente às alterações físicas, mas ao comportamento da paciente, por isso, segundo o autor, era importante que o médico se tornasse uma pessoa de confiança a quem ela pudesse contar seus segredos. ${ }^{29}$ 
Como conjunto de saberes sobre a mulher, os livros de medicina dos séculos XVIII e inícios do XIX construíram uma imagem sexualizada, sintetizada pela frase latina que foi insistentemente citada pelos médicos: tota mulier in utero. Embora os estudos anatômicos e fisiológicos da época fornecessem informações a respeito dos ovários, o útero continuou a ser o órgão feminino por excelência, pelo menos até o século XIX, quando os estudos de ovologia e ginecologia elegeram os ovários como os órgãos determinantes da natureza feminina. ${ }^{30}$

A vida das mulheres passou a ser descrita como uma sucessão de fenômenos fisiopatológicos. Assim, se durante a infância nada apontava para diferenças consideráveis entre meninas e meninos, a não ser aquelas decorrentes da educação, após a puberdade, os médicos referiam-se a um verdadeiro universo feminino, totalmente à parte do mundo racional dos homens. No tempo e no espaço das mulheres o corpo era determinante. Um excelente exemplo dessa forma de pensar é dada por Diderot, em 1780, quando faz uma linha cronobiológica para explicar a especificidade da mulher. Da puberdade até a chegada da velhice todo seu ciclo vital é marcado por 'incômodos' mensais - a menstruação - dores, debilidade física, perda da beleza e da capacidade de conceber com a chegada da menopausa.

Para cada fase da vida da mulher parecia ficar mais evidente para os médicos a íntima relação entre fisiologia e patologia. Talvez o melhor exemplo dessa relação seja a menstruação. Este fenômeno foi explicado como uma espécie de purgação, resultado do excesso de sangue no corpo, até que no século XIX passou a ser associado à ovulação. Se a menstruação era vista como um fenômeno fisiológico específico das mulheres, em contrapartida havia todo um campo de estados mórbidos associados que confirmavam a imagem da mulher doente. ${ }^{31}$

A gravidez e o parto também foram considerados estados predisponentes a manifestações mórbidas. Os tratados de obstetrícia dos séculos XVIII e XIX dedicaram muitos capítulos aos problemas que ocorriam nos dois momentos, além do fato de que a obstetrícia tornou-se uma especialidade médica a partir da experiência dos cirurgiões em atender somente a partos complicados, o que explica o grande interesse pela patologia dos partos.

Tem-se, assim, uma construção ambígua da mulher presente nos mais diferentes discursos, cuja vitalidade alcança o século XX. Se a mulher podia ser uma fonte de bondade e de outras virtudes tão enaltecidas por 
Rousseau e seus leitores, a mesma natureza física podia engendrar a maldade e o vício, a loucura e os comportamentos criminosos.

Dessa forma, criava-se uma imagem moralmente superior da mulher se o seu corpo cumprisse as funções sociais do casamento, da maternidade e da educação dos filhos, mas se a mulher não controlasse seus desejos e se entregasse ao mundanismo e ao desregramento, facilmente ultrapassaria a tênue fronteira entre a normalidade e a patologia, como tão incansavelmente os médicos vão alertar ao abordar temas como masturbação e prostituição.

Por mais paradoxal que possa parecer, o modelo de mulher produzido e divulgado pelos textos médicos e intelectuais durante o século XIX, nega o corpo, especialmente a sexualidade feminina, que deveria ser totalmente direcionada para a reprodução. ${ }^{32}$ A ambigüidade deste modelo pode ser explicada pela reorganização das relações de gênero da nova sociedade burguesa européia. Se até meados do século XVIII as mulheres das classes mais elevadas e cultas tinham maior participação nas decisões sobre a vida doméstica e cultural, com a ascensão das classes médias, propiciada pelo desenvolvimento mercantil e industrial, a figura feminina passou a ter outro papel: o de guardiã moral da família. A nova moralidade burguesa, tão bem definida por Rousseau no Emúlio (1762), tinha na mulher o seu principal sustentáculo, pois seguindo a ordem 'natural' das coisas, sendo o homem mais forte, ágil e inteligente, estava voltado para o mundo da política e dos negócios, enquanto a mulher, seu complemento natural, por ser mais fraca, passiva e emocional, deveria devotar-se ao espaço regenerador da alma masculina, o lar. ${ }^{33}$

Nesse novo mundo moral da família burguesa, a negação da sexualidade feminina era a contrapartida necessária para o bom desempenho de sua magna função moral de mãe e esposa. Ao escrever seus livros e tratados, os médicos tinham como modelo a mãe rousseauniana, cujo corpo fértil era determinante e, por isso, deveria ser saudável, mas completamente orientado nos seus ritmos biológicos para a maternidade.

No entanto, mesmo esta visão redentora da mãe com seu filho não estava isenta de inquietações. Por mais que os médicos e outros autores não especializados se esforçassem em entronizar a imagem dessexualizada da mulher-mãe, pairava sobre a maternidade a mácula da sexualidade, relembrada na gravidez, no parto, na própria amamentação e nas doenças das mulheres, pudicamente tratadas pelo médico iluminista que ainda não tocava nos castos corpos de suas pacientes. Os médicos e intelectuais 
dividiam-se quanto a esta ansiedade. Alguns acreditavam que a educação correta e bem orientada da menina, visando à boa formação moral e à contenção do corpo, iria resultar na mulher saudável, de caráter dócil e submissa ao seu esposo. Outros, contudo, desconfiados da natureza ambígua da mulher, temiam a sexualidade feminina e seus efeitos desestabilizadores para a família e a sociedade, seguindo uma longa e bem consolidada tradição misógina da cultura ocidental. ${ }^{34}$

Essas foram as duas grandes correntes do pensamento masculino a respeito da mulher, predominantes durante todo o século XIX, tanto no discurso científico e filosófico quanto na literatura, nas artes plásticas e nos textos de caráter sociológico, tão típicos da segunda metade do século. De Comte a Engels, de Michelet a Schopenhauer, de Flaubert a Zola, além da extensa produção médica que atravessa o século XIX, nunca se falou tanto da mulher, pelo menos não a tantas vozes. As figuras femininas presentes nos diferentes textos expressam o problema da definição da mulher para os homens cultos da sociedade européia, como bem observou Baudelaire (1996: 53-54):

O ser que é, para a maioria dos homens, a fonte das mais vivas e mesmo (...) dos mais duradouros prazeres; (...) esse ser terrível e incomunicável como Deus, (...) para quem e por meio de quem se fazem e se desfazem as fortunas, para quem, mas sobretudo a quem os artistas e os poetas compõem suas jóias mais delicadas; (...) a mulher, numa palavra, não é somente para o artista em geral, e para G. em particular, a fêmea do homem. É antes uma divindade, um astro que preside todas as concepções do cérebro masculino; (...) é o objeto da admiração e da curiosidade mais viva que o quadro da vida possa oferecer ao contemplador. É uma espécie de ídolo, estúpido talvez, mas deslumbrante, enfeitiçador, que mantém os destinos e as vontades suspensas a seus olhares.

É interessante notar como nessa definição Baudelaire arranja pares de oposição que sintetizam muito bem as diversas opiniões masculinas do século XIX a respeito da mulher. Ela é objeto de amor, mas, como a divindade, é incompreensível e controla os homens que lhe dedicam versos e riquezas; é uma entidade biológica, sem dúvida (a fêmea do homem), mas é um ídolo, um objeto de devoção; mesmo que pouco inteligente, é deslumbrante e onipresente nos olhares e no desejo masculino.

Divididos, os homens cultos escreveram a respeito da mulher em grande parte informados pelo discurso médico, que, ao longo do século XIX, ampliou consideravelmente seu alcance e sua autoridade, transformando o corpo feminino em um objeto de investigação científica e a feminilidade em um problema. Aos olhos dos intelectuais, os médicos 
adquiriram um status privilegiado, espécie de oráculos científicos a respeito do enigma feminino, pois suas verdades estavam sob a chancela dos fatos observados nos laboratórios, nas salas de autópsia e na clínica junto à crescente clientela feminina que passou a confiar seus segredos e problemas aos médicos. Este saber acumulado e constantemente renovado ao longo de todo o século XIX não ficou restrito aos bancos das faculdades de medicina e às publicações especializadas. A escrita masculina a respeito da diferença feminina é um notável exemplo da apropriação do saber médico e científico pelos intelectuais envolvidos com a questão da mulher, traduzindo para o público leigo as descobertas dos doutores.

De posse dos mesmos dados os intelectuais construíram narrativas e representações se não opostas, pelo menos qualitativamente diferenciadas, ora enaltecendo as virtudes do corpo materno dessexualizado, ora salientando a diferença sexual feminina como um signo da inferioridade e da desordem. Um dos mais importantes autores da época e que tanta autoridade vai ter a respeito da definição da mulher é Jules Michelet. Mais conhecido como o grande historiador da França, Michelet teve uma outra produção intelectual voltada para temas variados como o anticlericalismo, a história natural, a crítica social, a família e a mulher. Sobre esta Michelet escreveu dois livros históricos, Joana d'Arc, que constituiu o tomo V da História da França, publicado em 1841, e $A$ Feiticeira, lançado em 1862, e outros dois livros de caráter pedagógico-naturalista, $\mathrm{O}$ Amor, de 1858, e $A$ Mulher, publicado em 1859. Estes últimos tiveram cinco edições até 1861. A Mulher vendeu, só no primeiro ano de publicação, 13.000 exemplares. ${ }^{35}$

Quando publicou O Amor, Michelet estava seriamente envolvido na missão de contribuir para a educação do povo e, como bom seguidor de Rousseau, via na família e na união conjugal a base da sociedade. Escrito numa linguagem sem rodeios, O Amor é um livro inspirado nas idéias sobre o papel moral e regenerador da mulher, mas também nas teorias biológicas a respeito da diferença radical desta como fêmea do homem. Dessa forma, Michelet encontrou na biologia e na medicina os conhecimentos necessários para construir o seu modelo de mulher. Apoiado nos recentes estudos sobre a ovulação que já estavam disponíveis ao público interessado, Michelet deteve-se na natureza feminina, especialmente nas condições físicas peculiares à mulher, entrando em detalhes de sua anatomia e fisiologia, detendo-se na menstruação e no seu papel fundamental na vida da mulher. 
Embora tivesse um senso profundo da alteridade feminina, vendo homens e mulheres como seres completamente distintos, Michelet acreditava que através do amor ambos podiam se unir no casamento, defendendo a idéia da complementaridade sexual que foi tão bem aceita pelos intelectuais e cientistas envolvidos na questão. Adotando uma posição favorável à mulher, o autor acreditava na sua redenção através do amor e do casamento, ressaltando o papel da educação familiar na formação física e moral da mulher.

Em O Amor, Michelet define a mulher como um ser doentio devido aos imperativos da anatomia e da fisiologia, dizendo que mesmo em plena saúde ela ficava debilitada em torno de sete dias ao mês, estando, assim, recorrentemente ferida e necessitando de cuidados. O homem devia conhecer as origens da fragilidade física da mulher e cuidar dela, amá-la e colocá-la no altar do lar.

Estabelecidos o amor e o casamento como as bases para a sociedade, Michelet escreveu A Mulher para melhor definir seu papel, já que sua natureza havia sido objeto do outro livro. Como o lugar da mulher era o lar, o escritor começa o livro deplorando o trabalho feminino que tantos males podia causar à mulher e à sociedade; para ele, o corpo feminino não era adequado aos esforços físicos e nem podia ser submetido às condições muitas vezes insalubres dos locais de trabalho. Segundo o autor, o único trabalho admissível para as mulheres era o doméstico, ou melhor, aquele realizado no interior de seus próprios lares. Mesmo as profissões de governanta e professora não eram bem vistas por ele, pois a questão ressaltada era o fato de essas mulheres viverem sós, sem família, sem um homem que as guiasse e protegesse.

A mulher de Michelet é necessariamente submissa e dependente do homem. Comentando sobre a mulher culta e só, o escritor diz que, à vista do seu salvador, ela se humilha e confessa: preciso de um senhor. O papel do homem é transformar a mulher em 'Mulher', casando-se, tendo filhos e educando sua filha, esta sim, a criação do homem-pai, como explica o autor:

Com [a] boa esposa, associada, pelo menos de coração, à fé do marido, este, seguindo o caminho fácil da natureza, exercerá sobre sua filha uma incrível ascendência de autoridade e de ternura. A filha acredita tanto no pai! Cabe a ele transformá-la em tudo o que quiser. A força desse segundo amor, tão elevado, tão puro, deve formar nela a Mulher, o adorável ideal de graça na sabedoria, o único que possibilitará o recomeço da família e da própria sociedade. (Michelet, 1995: 48) 
O papel formador e transformador do homem é essencial para a educação da mulher. Se educar o menino significava organizar uma força produtiva, criar um criador, educar a menina significava harmonizar uma religião. Michelet é o autor da frase que contribuiu para a divulgação do culto romântico à mulher-mãe, tão presente na literatura e nas artes plásticas da metade de século XIX: 'a mulher é uma religião'.

Este culto adotou um modelo angelical e quase descorporificado da mulher, que recorria insistentemente às analogias entre mãe, santa, anjo e freira, exaltando o auto-sacrifício das mães na gravidez e no parto; o devotamento da santa-mãe ao lar, ao esposo e aos filhos; e o enclausuramento da mulher ao espaço da casa. Desenha-se, assim, com as mãos de Michelet, a imagem religiosa da mulher, tão bem representada pela Imaculada Conceição e pelas personagens dos romances e pinturas de temas associados à mitologia do culto à mulher. ${ }^{36}$

Embora a mulher de Michelet seja definida pelo corpo, ela não é nem a antiga figura médica ameaçadora da ninfomaníaca, nem a outra criatura do romantismo, a femme fatale. Ela é descendente da Virgem Maria e de outras madonas piedosas que povoavam as páginas dos livros de história de vidas de santas e de mulheres exemplares. Toda e qualquer ameaça é abafada ou, usando um vocabulário do século XX, sublimada pela sacralidade da maternidade. O corpo da mulher idealizada por Michelet é o corpo produtivo por excelência, o corpo normal, como definiam os médicos e biólogos contemporâneos da época; fonte da vida e do bem, como se pode observar na escultura "Maternité", de Guibourgé, imagem reproduzida no século XIX e presente em nosso imaginário até os dias atuais (Figura 1).

Mas esta imagem positiva e reabilitada da mulher não foi predominante nos meios científico e cultural do século XIX. A outra corrente do pensamento masculino sobre a mulher, fortemente misógina, contestou a 'religião da mulher', utilizando-se também das verdades científicas sobre o corpo feminino, só que procurando revelar seu lado escuro, perigoso e ameaçador para o homem e a sociedade. Sai de cena a santa, entra a degenerada.

A reação ao culto à mulher foi bastante virulenta, sendo uma poderosa alavanca da produção cultural e científica da segunda metade do século XIX. A descoberta da sexualidade feminina foi uma das origens dessa reação, mas as teorias sociais e científicas que tiveram lugar na mesma época também desempenharam seu papel na constituição do pensamento misógino que tanta influência teve no debate a respeito do papel da mulher na sociedade 
e nas justificativas contrárias às reivindicações feministas de autonomia e direitos políticos, debate este que envolveu mulheres, homens da ciência, médicos e intelectuais tanto na Europa quanto no outro lado do Atlântico.

\section{Figura 1 - Maternité}

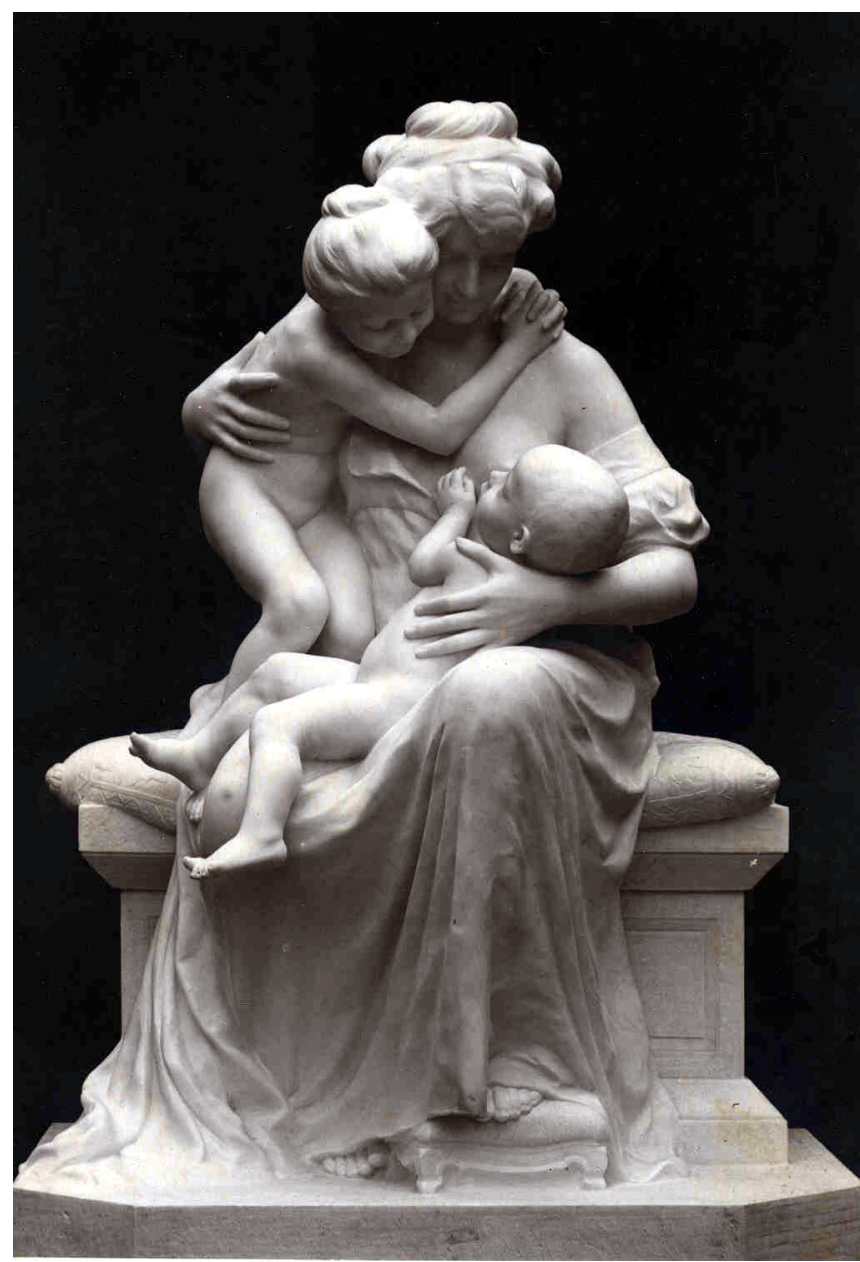

Imagem de forte apelo visual, esta madona laica simboliza a natureza feminina em sua versão reabilitada pelo ato da amamentação.

Fonte: A. Noyer Éditeur, Paris, s.d. 
Embora os livros mais importantes sobre a sexualidade tenham sido publicados nas últimas décadas do século XIX, o debate em torno da sexualidade feminina já vinha ocorrendo desde a década de 1860, na continuidade dos estudos sobre a reprodução. ${ }^{37} \mathrm{Na}$ verdade, a discussão não era especificamente sobre o comportamento sexual das mulheres casadas, a fim de saber se realmente elas eram insensíveis à paixão sexual, mas sobre as jovens mulheres, as adolescentes, cuja transformação de menina para mulher tanta ansiedade causou nos médicos e, por extensão, nos pais e professores.

Os tratados de higiene dedicaram muitas páginas a respeito da 'metamorfose' da jovem, cujo corpo passava por alterações drásticas que podiam comprometer a mente e o comportamento. Percebe-se uma oscilação nos discursos médicos entre o encantamento pelas transformações físicas, que tornaram o corpo feminino belo e gracioso, e o temor da sexualidade e dos males que ela poderia desencadear. Foi entre 1860 e 1870 que o tema da masturbação freqüentou os livros de medicina, sempre associado aos adolescentes, especialmente às mulheres, em um tom cada vez mais alarmista e moralista.

Seguindo uma tradição religiosa, os médicos revelaram os insidiosos hábitos privados das adolescentes, entregues ao 'vício' da masturbação, sozinhas ou com as amigas. Alertaram os pais e professores para que redobrassem a vigilância e admoestassem as meninas sobre a imoralidade e o perigo de tal prática para a saúde e a beleza. Em último caso, defendiam medidas mais drásticas como a contenção física, o uso de artefatos na região genital que deviam impedir a masturbação ou, como último recurso, intervenções químicas e cirúrgicas. ${ }^{38}$

Mas não eram apenas as adolescentes que se entregavam ao 'vício'. Na sua crescente intervenção clínica e aumento da desconfiança em relação às mulheres, alguns médicos estavam cada vez mais convencidos de que a masturbação era uma verdadeira praga que atingia igualmente mulheres casadas e viúvas. Em um manual muito citado sobre a masturbação, que já estava na sétima edição em 1897, Dr. Puillet explicava para aqueles que ainda não tinham compreendido a extensão do mal, que bastava lerem os romances de Gautier e de Balzac para ver como as mulheres se entregavam ao 'vício' e eram dominadas pelo desejo sexual.

Livros como do Dr. Puillet revelaram uma imagem feminina muito diferente da 'mulher ferida' ou da mãe dessexualizada presente nos escritos 
de Michelet. Crescia a conviç̧ão de que a mulher era dominada pelo sexo, ou melhor, pelo desejo sexual. Esta imagem é um desdobramento da especificidade sexual feminina, com a diferença de que o sexo passa a ser visto como determinante para a vida da mulher. Mesmo a mais casta esposa podia ser despertada para o sexo, pois era da natureza feminina as mais desenfreadas paixões, como pensavam os médicos e muitos outros homens que construíram a imagem hipersexualizada da mulher. ${ }^{39}$

Contudo, os argumentos mais poderosos contra a visão romântica da mulher não se sustentavam apenas nos escritos dos médicos que desconfiavam da natureza feminina, mas igualmente em uma nova e implacável teoria que mudou completamente a maneira de ver a Natureza e a história da humanidade. Trata-se do evolucionismo darwinista.

Antes de Darwin formular a teoria da evolução das espécies pela seleção natural, a idéia de evolução já era discutida nos meios científicos da Europa. A partir da metade do século XVIII, os estudos de botânica, zoologia e paleontologia colocaram em xeque o princípio da fixidez das espécies. Investigações no campo da anatomia comparada, especialmente, apontavam para um processo de transformação das espécies, embora as explicações para tal processo fossem ainda insuficientes. Toda uma nova concepção da Natureza estava nascendo dos estudos da geologia, da paleontologia e biologia, associando a evolução a um lento processo histórico de transformação da Terra e dos seres vivos.

Darwin conhecia bem essas discussões e informado por elas e pelas observações que fez na viagem que empreendeu a bordo do Beagle, a partir de 1831, começou a esboçar seu trabalho sobre as transformações das espécies. A leitura do ensaio de Malthus sobre a população certamente influenciou Darwin nas suas investigações, levando-o a formular a lei da evolução das espécies a respeito da luta pela sobrevivência dos mais aptos. ${ }^{40}$

Em 1859, Darwin publicou A Origem das Espécies, dando uma explicação para a evolução mediante o processo da seleção natural, um fenômeno físico, que derrubava, por sua vez, com a idéia da imutabilidade das espécies. Apesar das reações negativas, a teoria darwinista sobre a evolução foi muito bem aceita por ser histórica, materialista e otimista, qualidades muito valorizadas na sociedade burguesa, na qual a idéia de progresso estava diretamente associada ao sucesso econômico, ao enriquecimento e à expansão mercantil e industrial. Hubbard (1982) comenta que a concordância da teoria da evolução darwinista com o 
liberalismo econômico foi observada por Marx e Engels (apud Hubbard, 1982: 23) alguns anos após a publicação de $A$ Origem das Espécies: "É notável como Darwin reconheceu entre as plantas e os animais sua própria sociedade, com suas divisões de trabalho, competição, abertura de novos mercados, 'invenções' e a 'malthusiana' luta pela existência".

Embora Darwin não tenha formulado seu conceito de seleção natural para explicar transformações sociais, é evidente que os termos e as expressões utilizadas, bem como as principais conclusões de sua teoria estavam impregnadas das idéias e valores produzidos por sua época, como bem percebeu Marx.

A idéia da sobrevivência do mais apto ou mais forte foi muito bem vinda para os teóricos sociais da segunda metade do século XIX. O conceito formulado a partir da observação de plantas e animais migrou para o universo das relações sociais, tornando-se um valioso instrumento para estudar as diferenças humanas e as transformações sociais que promoviam a evolução do homem.

Na verdade, a idéia da seleção natural pela sobrevivência dos mais aptos já havia sido antecipada por Herbert Spencer no livro Estática Social, publicado em 1850, no qual o autor justificava o comportamento individualista, competitivo e predatório da sociedade capitalista, dizendo que a extinção dos mais fracos era um mecanismo natural da sociedade. Portanto, quando Darwin divulgou sua teoria já havia um ambiente cultural e científico propício para a sua aceitação. O encontro entre a teoria darwinista e as idéias spencerianas resultou em uma doutrina muito divulgada no final do século XIX tanto na Europa quanto nos Estados Unidos: o darwinismo social.

Spencer transitava entre a teoria da evolução e a craniologia para fortalecer seus argumentos sobre as diferenças humanas. Para ele, a evolução era um processo de transformação do mais simples para o complexo, da homogeneidade para a heterogeneidade, portanto, quanto mais evoluída a sociedade, maiores as diferenças entre os homens. Se com essas idéias Spencer justificava a existência das classes sociais e das desigualdades entre os pobres e ricos, foi com os dados da craniologia que ele justificou o estágio mais evoluído dos brancos europeus. ${ }^{41}$

A teoria da evolução e a craniologia forneceram os argumentos e as justificativas científicas para as desigualdades sociais, raciais e sexuais na segunda metade do século XIX. O próprio Darwin aqueceu o debate em 
torno das diferenças e desigualdades humanas ao publicar, em 1871, o livro A Descendência do Homem em que o conceito de seleção é relacionado ao sexo. Neste livro, além de estabelecer analogias entre raça e sexo, tão familiares à tradição cultural e científica, Darwin defendeu a idéia de que a competição masculina para conquistar a caça e as fêmeas fez com que o homem se desenvolvesse mais que a mulher, explicando, assim, a evolução sexual:

De maneira geral, admite-se que, na mulher, as faculdades de intuição, de percepção rápida e talvez de imitação são mais desenvolvidas que no homem; mas pelo menos algumas dessas faculdades são características das raças inferiores e, portanto, de uma etapa passada e inferior da civilização. A principal distinção entre os dois sexos em matéria de faculdades intelectuais é demonstrada pelo fato de o homem conseguir atingir, em tudo o que empreende, maior proeminência do que a mulher, quer isto requeira raciocínio profundo, razão, imaginação ou apenas o uso dos sentidos e das mãos. (Darwin apud Gould, 1993: 275)

Nesta breve mas significativa passagem estão expostos os principais elementos que compunham os discursos sexistas e racistas do final do século XIX, como as analogias entre mulheres e raças inferiores, hierarquias de raças e culturas e a inferioridade do sexo feminino.

A seleção sexual era um tema também presente em outro tipo de investigação: a craniologia. Um dos mais famosos craniologistas do século XIX, Carl Vogt, fez centenas de medições em crânios de mulheres e de indivíduos de outras raças para provar que ambos eram inferiores quanto ao tamanho e à capacidade intelectual. A mulher foi comparada aos 'selvagens' ou 'primitivos' porque, da mesma forma que estes tinham chegado em um nível de evolução inferior às raças brancas, a mulher também tinha estacionado na linha evolutiva, ficando mais próxima às raças inferiores e às crianças. ${ }^{42}$

De uma maneira geral, a imagem feminina criada pelo evolucionismo e pela craniologia, tão divulgada por médicos, antropólogos, sociólogos e outros especialistas nas diferenças sexuais, é uma imagem negativa e depreciativa. Há diferenças importantes entre os autores, sendo alguns mais otimistas ao acreditar no sentido progressista da evolução; mas havia uma corrente bastante forte no final do século que associava feminilidade à degeneração.

Essa corrente abertamente misógina encontrou adeptos não somente na ciência, mas em outros domínios da cultura, como vários autores que estudam a história cultural do século XIX vêm mostrando. A desconfiança em relação à mulher e a tudo associado à feminilidade estava na origem de 
vários textos alarmistas que foram típicos do pensamento intelectual do fim do século passado. Bem distantes estavam aqueles homens das posições de Michelet e dos 'adoradores de mulheres', tão execrados por Schopenhauer. A ênfase do discurso misógino estava na divisão da espécie humana em dois sexos hierarquicamente desiguais. Diferentemente de Michelet e de outros defensores da mulher, os misóginos não acreditavam na complementaridade sexual e não viam nenhuma redenção do sexo feminino na maternidade. Esta era entendida como uma função natural, sem nenhum outro tipo de qualificação, a não ser produzir filhos.

Se esse pensamento trazia em germe as antigas representações ambíguas sobre a mulher, no contexto do final do século XIX ele tem outro significado: a mulher, ou melhor tudo que estivesse associado à feminilidade, podia despertar as forças da degeneração. Nem todos os evolucionistas eram otimistas; um importante movimento tomou corpo na época temendo a reversão no processo da evolução humana em direção à animalidade. Os intelectuais dessa linha de pensamento passaram a ver sinais da degeneração não somente nas chamadas raças inferiores, mas igualmente na sociedade moderna. Como os degeneracionistas eram profundamente reacionários, a maioria deles construiu uma imagem negativa da modernidade, associando-a à reversão e às idéias de declínio e esgotamento. As principais personagens deste cenário assombroso eram os pobres, os homossexuais, as prostitutas e as mulheres modernas - essas 'aberrações' que queriam usurpar o lugar dos homens e submetê-los ao seu poder.

Essa verdadeira paranóia masculina teve grande repercussão, como demonstra o acolhimento de alguns livros produzidos na época, escritos em tom muito alarmista, como Degeneração, de Max Nordau, publicado em 1893, e Sexo e Caráter, de Otto Weininger, de 1903 (Dijkstra, 1988: 212). ${ }^{43}$ Este levou a misoginia ao extremo ao escrever um livro abertamente contrário às mulheres, apoiando-se na tradição intelectual e científica para destilar todos os preconceitos produzidos pelo pensamento sexista e racista. Weininger defendeu a superioridade natural do homem com base na teoria da evolução e na craniologia. Segundo sua interpretação da evolução, no homem predominava o cérebro, a capacidade da transcendência e das atividades do espírito, enquanto na mulher era o sexo, predominando somente o físico e a capacidade reprodutiva. Não faltaram no livro as analogias entre mulheres e raças inferiores, já bastante conhecidas pelo autor e por seus leitores. ${ }^{44}$ 
Suas idéias e de outros que pensavam como ele foram muito bem acolhidas no seio da cultura fin-de-siècle, em que a chamada 'questão da mulher' tomava cada vez mais o aspecto da guerra dos sexos. A presença feminina nas universidades, nos meios intelectuais, no trabalho e, maior heresia, na política, despertava a ira de homens como Weininger, que viam em cada reivindicação feminina uma ameaça à ordem social.

A idéia funcional da natureza feminina foi bem desenvolvida por um dos pensadores misóginos mais citados por médicos e intelectuais da época: Schopenhauer. Em um breve, mas significativo texto, o autor sintetiza as principais idéias e os preconceitos contra as mulheres na época, demonstrando sua total descrença quanto à possibilidade da evolução feminina. É muito difícil ler qualquer texto a respeito da mulher no final do século XIX que não tenha alguma citação ou referência às idéias de Schopenhauer, expressas em seu Ensaio sobre as Mulheres, publicado pela primeira vez em 1880.

Na sua definição da mulher, Schopenhauer lança mão de um dos mais poderosos clichês culturais da época que era a incapacidade intelectual do sexo feminino. Diz que seu aspecto físico é revelador de que seu destino não está associado aos trabalhos da inteligência, mas à reprodução da espécie e ao cuidado das crianças. Sua natureza não permitia esforços ou prazeres excessivos, sendo seu destino obedecer ao homem, apoiá-lo, cuidar das crianças e levar sua vida "silenciosamente, de forma insignificante e docemente" (Schopenhauer, 1900: 129).

A inclinação natural da mulher em cuidar dos outros era explicada pelo autor por sua natureza infantil, sendo a mulher uma intermediária entre a criança e o homem; assim, o autor reproduzia outra importante representação - a mulher-criança.

Schopenhauer não se curva nem ao mais destacado argumento favorável às mulheres: a beleza. Para ele, a beleza era um instrumento fornecido pela Natureza para a mulher conquistar o homem, sendo por isso tão realçada até a idade do casamento e da maternidade. Depois desta fase de conquista, a beleza não era mais necessária, pois já havia cumprido sua função. ${ }^{45}$

Mas os argumentos principais do autor a respeito da inferioridade feminina referem-se às diferenças intelectuais. Como bom evolucionista, Schopenhauer diz que os seres que se desenvolvem mais lenta e tardiamente são mais nobres e perfeitos. Trazendo este raciocínio para as diferenças sexuais, explica que pelo fato de as mulheres amadurecerem sexualmente 
mais cedo - por volta dos 18 anos -, enquanto nos homens a razão e a inteligência só vão alcançar a plenitude aos 26 anos, elas permaneciam infantis durante toda a vida, sofrendo de uma miopia intelectual que as impedia de ter o pensamento racional e desenvolver o interesse pelas artes e pela ciência.

O filósofo foi um dos responsáveis pela divulgação dos mais perniciosos preconceitos contra as mulheres como a ausência de sentido de justiça, a falsidade, a infidelidade, a traição, a ingratidão e ausência do sentimento do belo. ${ }^{46}$ Em suma, Schopenhauer destilou todo seu preconceito contra as mulheres, o qual era moeda corrente no meio cultural em que ele viveu. Totalmente contrário ao endeusamento das mulheres, afirmou serem elas "o sexus sequior, o segundo sexo sob todos os aspectos, feitas para se ter à distância e em segundo plano. (...) A Natureza, ao separar a espécie humana em duas categorias, não as fez iguais" (Schopenhauer, 1900: 138). Portanto, a dama européia, figura tão desprezada por Schopenhauer, não deveria ser objeto da 'estúpida veneração' que os homens prestavam; o autor se mostrava um admirador dos povos antigos e dos orientais, que, segundo ele, sabiam colocar as mulheres no seu devido (e segundo) lugar.

Para o autor, só deveria existir a 'mulher de casa', dedicada aos seus afazeres domésticos, avessa à arrogância e sujeita ao trabalho e à submissão. Schopenhauer é um crítico feroz à monogamia, declarando-se admirador dos mórmons e de suas práticas poligâmicas; acreditava que, com a supressão da monogamia, todas as mulheres encontrariam seu verdadeiro lugar sob o controle e o domínio dos homens. Para Schopenhauer, o ataque à dama e a defesa da poligamia faziam parte de sua visão a respeito das relações de gênero, onde o homem deveria ter todo o poder:

É evidente que a mulher é, por natureza, destinada a obedecer e a prova disso é que ela se liga não importa com que homem, para que ele a dirija e domine, pois ela precisa de um senhor. Se é jovem, procura um amante, se é velha, um confessor. (Schopenhauer, 1900: 141)

Ao defender essas idéias, o autor fechava definitivamente as portas das universidades, das fábricas, dos ateliês, dos hospitais e da vida política para as mulheres. Para ele, bem como para outros autores, o lugar do segundo sexo era a casa; sua função, a maternidade. Schopenhauer tinha ao seu lado, apoiando suas idéias, muitos médicos que brandiam argumentos contrários à educação superior e ao exercício dos direitos políticos. Dessa forma, Schopenhauer não abria nenhuma possibilidade 
para as mulheres, a não ser cumprir suas funções naturais. Fora desse destino traçado pela evolução sexual, só a degeneração.

Mas, o mais significativo representante do pensamento científico a respeito da evolução e das diferenças sexuais foi o livro publicado em 1896 por Lombroso e Ferrero, La Donna Delinqüente (1923). Mais do que uma reflexão sobre a prostituta e a mulher criminosa, este livro tão citado e que tanta ascendência teve em todos os centros acadêmicos da Europa, Estados Unidos e América Latina é um tratado sobre a mulher e um exemplo do pensamento dicotômico e do funcionamento do gênero na linguagem e na estrutura do conhecimento científico.

Em 1876, Lombroso havia publicado o livro que iria torná-lo mundialmente famoso e respeitado na medicina e na antropologia, O Homem Criminoso, no qual desenvolveu sua teoria do criminoso nato. O atavismo foi definido pelo autor como uma força de reversão a estágios menos evoluídos da espécie humana, sendo hereditário e perceptível nos indivíduos mediante estigmas, como o tamanho do crânio e certas medidas faciais e corporais. A reversão explicaria o comportamento criminoso e a prostituição, os dois temas que foram objeto dos estudos de Lombroso. ${ }^{47}$

Seguindo o plano da obra de Lombroso e Ferrero (1923), o estudo sobre a mulher também toma como referência a teoria da evolução pela seleção natural e a craniologia, mas os autores recorrem a uma vasta e diversificada bibliografia em que entravam botânicos, zoólogos, médicos, anatomistas, fisiologistas, antropólogos, filósofos, historiadores e escritores para construir sua teoria a respeito da mulher normal e da criminosa. Em todo o livro há uma constante preocupação em sustentar as idéias expostas com dados quantitativos, o que demonstra a intenção dos autores em se fundamentar nos fatos observáveis e em frisar o caráter eminentemente científico e verdadeiro do trabalho.

Para definir a mulher normal, Lombroso e Ferrero primeiro explicaram como se deu a evolução sexual nos animais. Usando vários exemplos do comportamento animal, os autores afirmaram que a fêmea só é superior ao macho nas espécies inferiores, como entre os crustáceos, insetos, aracnídeos e vermes, citando várias passagens de Darwin e outros naturalistas que fizeram pesquisas comparativas entre seres humanos e animais. Subindo a escala evolutiva, o macho passava a ter supremacia, tendo como exemplo os mamíferos, salientando entre estes os primatas e estabelecendo analogias com os humanos. Como conclusão importante da 
discussão sobre as diferenças sexuais entre os animais estava a idéia de que os machos representavam o elemento dinâmico e variado da espécie, enquanto as fêmeas representavam o tipo médio. Essa é uma idéia que vai ser apropriada para entender as diferenças sexuais entre os seres humanos, justificando, através da indiferenciação da mulher e de sua ligação aos interesses da espécie, a reclusão ao lar e à maternidade. ${ }^{48}$

Um dos capítulos mais importantes na utilização do gênero como categoria do pensamento científico é o que trata da anatomia e da biologia da mulher normal. As comparações estabelecidas entre as variáveis manipuladas pelos autores são dispostas em uma hierarquia de gênero em que todos os resultados apontam para a inferioridade da mulher. Tal como no livro anterior, é grande a obsessão com as medidas e os detalhes anatômicos. Quantifica-se tudo: peso, estatura, capacidade vital, força muscular, presença de pêlos, volume das vísceras, gordura corporal, capacidade craniana, enfim, a busca pelos sinais físicos da diferença sexual chega aos limites do absurdo detalhista, como, por exemplo, os dados a respeito da composição do sangue dos dois sexos. ${ }^{49}$ Com todas as medidas expostas, os autores fazem diversas comparações, todas confirmatórias dos estudos craniológicos e evolucionistas que estabeleciam proximidades evolutivas entre a mulher, a criança e as raças inferiores.

Uma importante diferença sexual ressaltada no livro e que mais uma vez demonstra a sintonia dos autores com as idéias médicas da época é a menstruação. Lombroso e Ferrero reforçam a importância deste fenômeno fisiológico na vida da mulher, o que a tornava inapta para o trabalho físico e intelectual, irascível e mentirosa. Apoiados nas pesquisas fisiológicas e nas informações dos ginecologistas, os autores afirmam que, devido às transformações físicas e psíquicas proporcionadas pela menstruação, as mulheres menstruadas podiam cometer delitos e até mesmo o suicídio. ${ }^{50}$

Todos os fatos observados apontavam para a conclusão de que a mulher era mais infantil do que o homem. Da mesma forma que as medidas e as avaliações sobre o corpo eram índices do menor desenvolvimento da mulher, os sentidos e sua organização psíquica também confirmavam as mesmas idéias. No capítulo sobre os sentidos, os autores afirmavam que a mulher suportava mais a dor, tinha menor sensibilidade sexual e todos os sentidos eram menos desenvolvidos, daí a conclusão: "A mulher sente menos, como pensa menos e, assim, se confirma a máxima de Aristóteles: Nihil est in intellectu quod prius non fuerit in sensu" (Lombroso \& Ferrero, 1923: 54). 
Todo o capítulo sobre os sentimentos nas mulheres repete os clichês culturais a respeito da inferioridade do sexo feminino, incluindo a referência a autores tradicionais, como Aristóteles, e contemporâneos, como Nordau, Spencer, Comte, Galton, Darwin e Schopenhauer, este último sendo citado várias vezes, bem como sua imagem da mulher-criança.

Apesar do determinismo de Lombroso e Ferrero, eles encerram suas discussões sobre a mulher normal com uma visão otimista. Para eles, a vida civilizada de países como a Inglaterra e Estados Unidos podia elevar a inteligência das mulheres a níveis mais próximos dos homens; desse modo, os autores acreditavam na força evolutiva da educação e das instituições sociais das 'raças evoluídas'. ${ }^{51}$ Se por um lado o livro é uma peça do determinismo biológico e das representações negativas da mulher, reproduzindo velhas fórmulas e definições correntes sobre a alteridade feminina; por outro, Lombroso e Ferrero adotam uma visão meliorista a respeito da evolução sexual, mesmo que de forma tímida.

O que é importante ressaltar da leitura de textos médicos como este e da produção cultural contemporânea a Schopenhauer e Lombroso e Ferrero é que a ânsia em entender e explicar a diferença feminina fazia parte de um procedimento justificador da ordem social, fundado na naturalização das diferenças humanas. Este processo teve um papel fundamental na constituição de novos saberes, sendo a diferença feminina uma das mais procuradas. Da mesma forma que as raças dos povos 'primitivos' foram objeto da antropologia e da craniologia, que os criminosos e as prostitutas estavam na origem da criminologia, as mulheres, na sua suposta radical diferença física e mental dos homens, também foram transformadas em categorias naturais do conhecimento médico-científico.

Em meio às diversas citações que Lombroso e Ferrero fizeram, destacam-se várias vezes as referências aos ginecologistas e obstetras, uma categoria de especialistas que, ao longo do século XIX, passa a construir imagens autorizadas a respeito da natureza feminina. Representantes de um novo campo do saber sobre a mulher, os médicos do século XIX foram tributários da ciência sexual do século anterior. No entanto, não bastava conhecer as diferenças, nominá-las ou mensurá-las. O processo de conhecimento das diferenças sexuais apenas dava seus primeiros frutos com a anatomia, a fisiologia e a craniologia, mas era preciso ir além, sair do terreno das generalidades da medicina clássica, criar um vocabulário próprio, desenvolver tecnologias adequadas à natureza do objeto, enfim, 
integrar os saberes disponíveis em um novo campo discursivo, em uma especialidade voltada para a diferença feminina. Os obstetras e ginecologistas foram os artífices deste processo de transformação do corpo feminino em um objeto do conhecimento, completando o círculo da ciência sexual. Nascia uma nova ciência: a ciência da mulher.

\section{Notas}

1 Sobre Francis Bacon e suas metáforas sexuais, ver Keller (1985).

2 Esta é a conclusão dos trabalhos de Laqueur (1992) e Schiebinger (1994).

3 Sobre os manuais sexuais produzidos no século XIX, ver Gay (1988) e o artigo de Bush (1999).

4 Para Debay, a relação sexual era um jogo de poder. Para manter o marido sob seu controle e não dar motivo para que ele cometesse adultério, Debay aconselhava as esposas a ceder aos desejos sexuais dos maridos e mesmo fingir prazer sexual se fosse o caso. Às críticas endereçadas aos seus conselhos, Debay (1901: 92-93) respondeu: "a esposa que assim se portar dará mostras de nobreza de coração, de elevação de espírito, de bom senso e de admirável energia. As mulheres deste quilate são mui raras, é certo, mas existem; estas tais conseguem sempre captar a afeição do homem, corrigi-lo dos seus defeitos, governá-lo, tornando-se-lhes indispensáveis e vindo por fim, a dominá-lo".

5 Sobre o poder do cientista de transformar os fenômenos incomuns em fenômenos naturais acessíveis ao conhecimento, ver Said (1996).

6 Essa visão hierárquica tem ligações com as teorias humorais de Hipócrates sobre as relações entre os quatro humores (sangue, fleugma, bile amarela e bile negra), os quatro temperamentos (sangüíneo, fleugmático, colérico e melancólico), os quatro elementos (ar, água, fogo e terra) e os quatro atributos (calor, frio, seco e úmido).

7 Embora estejamos nos referindo às interpretações médico-filosóficas sobre as diferenças sexuais, é importante salientar que essa visão hierárquica que organizava as relações de gênero, bem como a idéia da imperfeição do sexo feminino e de sua natureza, foi igualmente reproduzida pela tradição religiosa judaico-cristã.

8 Essa é também a conclusão de Schiebinger (1989), ao analisar a questão da diferença sexual nos textos de Aristóteles e de Galeno.

9 Sobre os expedientes usados pelos mestres anatomistas e seus discípulos, ver o excelente romance de Andahazi (1997). Laqueur (1992) comenta que há uma tradição folclórica de relatos sobre o roubo de cadáveres nos cemitérios por parte dos alunos das escolas de medicina.

10 Laqueur (1992) diz que essa é uma explicação para o número maior de ilustrações anatômicas do corpo masculino, mas lembra que muitas mulheres, especialmente da nobreza, tiveram seus corpos examinados ou dissecados pelos anatomistas.

11 Segundo Foucault (1982), a jurisprudência medieval a respeito dos hermafroditas mostra que o sexo era determinado pelo pai ou padrinho do recém-nascido, mas na idade 
adulta o indivíduo poderia escolher continuar com o sexo que lhe fora atribuído ou optar pelo outro sexo. Escolhido o sexo este não podia ser mudado novamente, pois o indivíduo incorreria no crime de sodomia. Foucault diz que os casos de condenação à morte dos hermafroditas se devia à mudança de escolha e não por imperativos anatômicos.

12 Matteo Colombo foi professor de anatomia na Universidade de Pádua, onde sucedeu Vesalius, que foi um dos mais importantes anatomistas do século XVI e o primeiro a representar o corpo feminino com maior fidelidade à realidade observada nas dissecações. Vesalius desafiou as teorias galênicas, ao provar que Galeno utilizou-se da anatomia de animais para descrever o corpo humano. Seu livro mais importante é o estupendo De Corporis Humani Fabrica, publicado em 1543, ricamente ilustrado com xilogravuras. Seu sucessor, Colombo, foi o primeiro anatomista a descrever em detalhes o clitóris, que chamou de pênis feminino e também de dulcedo amoris ou amor veneris, abrindo uma discussão, um tanto perigosa para a época, a respeito do órgão feminino do prazer sexual. Sobre Matteo Colombo e sua descoberta, ver Andahazi (1997); sobre a anatomia seiscentista, ver Laqueur (1992) e Ronan (1997).

Sobre o conceito de esquema e seu papel na produção das representações, ver especialmente o capítulo Verdade e estereótipo, de Gombrich (1986).

Sigo aqui as discussões desenvolvidas pela história da ciência e do gênero presentes nos livros de Bleir (1984) e Schiebinger (1994).

15 A discussão que envolveu diversos intelectuais dos séculos XVII e XVIII, como Poulain de la Barre, Mary Wollstonecraft, Mme. D’Epinay, Rousseau, Diderot, entre outros, está sintetizada no livro prefaciado por Badinter (1985), no qual são apresentados três argumentos sobre a questão defendida por Thomas, Diderot e Mme. D'Epinay. Ver Thomas (1991).

16 Schiebinger (1994) analisou o significado do gênero nos estudos feitos por Lineu a respeito da classificação das plantas e dos mamíferos, como também a antropoformização dos primatas, mostrando a relação entre gênero e raça nos discursos científicos a respeito das diferenças entre seres humanos e animais.

17 Há que se distinguir entre as teorias racialistas do século XVIII e aquelas formuladas no século XIX. Para os iluministas, as diferenças raciais eram pensadas em termos de classificação de culturas, de oposição entre civilização e barbárie, enquanto para os cientistas raciais do século XIX as diferenças eram visíveis e mensuráveis, localizando no corpo os indícios da superioridade e da inferioridade das raças, materialismo este que vai desembocar na eugenia e suas práticas de melhoramento das raças pelo controle político dos corpos, que previa o extermínio dos indivíduos não aptos para manter a pureza da raça.

Ver Ronan (1997: 25).

Sobre as coleções de animais e de africanos, ver Schiebinger (1994).

Camper desenvolveu a noção de ângulo facial, uma medida tomada entre a fronte e o maxilar, cujos ângulos variavam da medida mais perfeita - 100 graus - tomada das estátuas gregas, até a mais primitiva - 42 a 50 graus - tomada dos macacos e orangotangos. Segundo esta classificação hierárquica do ângulo facial, os negros e asiáticos ocupavam uma posição intermediária entre os animais e os brancos, com o ângulo de 70 graus. Os brancos apresentavam a medida mais próxima da perfeição, com 80 graus. Sobre Camper, ver Schiebinger (1994: 149-152) e Darmon (1991: 20). 
21 Assim como houve uma classificação racial baseada nas diferentes medidas de crânios, também houve uma classificação racial da pélvis: a oval era característica das mulheres européias; a quadrada predominava entre as mongóis; a redonda era típica das mulheres indígenas americanas, e a oblonga, mais parecida com a pélvis das fêmeas animais, predominava entre as mulheres africanas. É interessante observar as torções racistas no pensamento racialista através da explicação para a aparente facilidade que as africanas teriam em dar à luz. Esta observação estava em muitos manuais de obstetrícia, mas levantava um problema, pois se as européias eram de uma raça superior como poderiam ter pélvis mais estreita que as africanas? A solução para este paradoxo foi simples: não eram as mulheres africanas que tinham pélvis mais larga: seus bebês é que tinham crânios poucos desenvolvidos, daí a facilidade dos partos (Schiebinger, 1994: 156-160).

2 Não caberia numa nota os trabalhos publicados sobre essa temática, mas cabe citar, especialmente, a coletânea organizada por Duby \& Perrot (1994).

23 A ginecologia, a ciência da mulher, é o corolário de todo este conjunto heterogêneo de discursos médicos, filosóficos e científicos sobre a mulher, transformando-a num objeto de conhecimento por sua natureza sexual. A constituição da ginecologia, que se deu na segunda metade do século XIX, será analisada no Capítulo 3.

${ }^{24}$ Sobre a auto-atribuição desmitificadora da medicina dos séculos XVIII e XIX, ver Gélis (1984) e Shorter (1984). A respeito dos mitos e crenças sobre a fecundação e a gravidez, ver Barbaut (1991).

25 Sobre Rousseau e sua visão da mulher e da maternidade como função social, ver Badinter (1985) e Crampe-Casnabet (1991).

26 Ao analisar os discursos de exaltação à capacidade reprodutiva do corpo feminino, Mary Del Priore mostra que, ao lado da medicina, a Igreja contribuiu muito para a divulgação de um imaginário materno, com as representações da Virgem grávida, como a Nossa Senhora da Conceição, da Encarnação e do Bom Parto. Segundo a autora, o útero teve um importante papel na definição da mulher, "constituindo-se em locus de certezas e incertezas sobre a natureza feminina e ganhando status inelutável. Sua valorização levava também a uma valorização da sexualidade feminina, não no sentido de sua realização e sim de seu adestramento, num caminhar bem coerente com a pretensão da ciência médica e da Igreja" (Del Priore, 1993: 205). Esta passagem aponta para uma questão fundamental dos discursos médico, filosófico e religioso do século XVIII, que é o caráter normativo da valorização da mulher-mãe. No século XIX, com o fortalecimento da ideologia da domesticidade, a valorização da mulher representou a melhor expressão da normatização dos papéis de gênero e dos comportamentos femininos.

27 A idéia de que o útero vagava pelo corpo vem de Platão: "O útero é um animal que deseja ardentemente produzir filhos. Quando se conserva durante longo tempo estéril, depois da puberdade, tem dificuldade de sofrer com paciência, irrita-se, percorre todo o corpo, fechando as saídas de ar, paralisando a respiração, lançando o corpo em perigos extremos e ocasionando diversas moléstias, até que o desejo e o amor reunindo o homem e a mulher façam nascer um fruto e o colham como numa árvore" (Timeu apud Silva, 1906: 1). 

ção de um óvulo em mamífero, realizada por Karl Ernst von Baer. O processo de investigado a partir da década de 40 do século XIX. Ver Laqueur (1992: 211-214). Sobre as causas morais da ninfomania, ver o interessante tratado de Bienville (1996). Bienville (1996: 61) estabelece seis passos no diagnóstico da ninfomania: "I - Se a enferma apresenta alguma inclinação que se esforça em não apagar; II - Se essa inclinação é a causa de sua languidez; III - Se, ao contrário, por vício de temperamento, sente-se atraída pelo primeiro que se lhe apresenta; IV - Se sacia-se solitariamente com masturbação; V - Se sua evacuação é pouco ou copiosa; VI - Se, finalmente, ela é ardente, impertinente, taciturna, hostil a conversas honestas com as quais os jovens bem educados costumam comprazer-se".

Um dos mais famosos e completos tratados de emenologia do século XIX foi organizado em 16 capítulos, dos quais sete são dedicados à patologia e à terapêutica da menstruação. Ver Raciborski (1868).

32 Essa visão cristã da sexualidade, bem como a contenção do corpo, não era predominante, embora fosse muito divulgada por médicos e moralistas. Sobre a gratificação sexual de casais vitorianos e a vazão do desejo sexual feminino, ver Degler (1974) e Gay (1988). Um dos mais vendidos manuais sexuais do século XIX, Every Woman's Book, de Richard Carlile, publicado em 1826 na Inglaterra, defendia o controle da natalidade e os prazeres do sexo para homens e mulheres igualmente. Ver Bush (1999). Sigo as análises desenvolvidas por Badinter (1985).

34 Sobre a contenção dos corpos, ver o livro de Brown (1990). Sobre o pensamento misógino há vários trabalhos, dos quais destaco Duby (1988); Dottin-Orsini (1996); Dijkstra (1988). Um exemplar dessa tradição misógina é o Malleus Maleficarum, manual dos inquisidores Kramer e Sprenger, escrito em 1484, condensando a desconfiança, o ódio e a perseguição às mulheres acusadas de feitiçaria. Publicado no Brasil, em 1991, com o título O Martelo das Feiticeiras, o livro tem a introdução de Rose Marie Muraro e prefácio de Carlos Byington. Informações presentes no livro de Jordanova (1989).

36 Sobre as representações românticas da mulher na literatura e na pintura européia, ver Dijkstra (1988). A respeito da divulgação do modelo angelical e sua aceitação pelas mulheres, ver Corbin (1995).

37 Refiro-me aos livros de Ellis (1894), Kraft-Ebing (1886), Garnier (1889) e Morel (1905).

38 Ver Corbin (1991, 1995).

अ Segundo Mirbeau (apud Dottin-Orsini, 1996: 154), "a mulher não tem cérebro; ela é um sexo, nada mais". Dijkstra (1988) mostra como a masturbação e a sexualidade feminina foram abordadas na pintura do tema da mulher desmaiada, lânguida, inativa e exausta, exposta ao olhar masculino.

40 Sobre a inspiração malthusiana no trabalho de Darwin, ver Hubbard (1982) e Macfarlane (1990).

41 Sobre o darwinismo social, ver Dijkstra (1988) e Jones (1998).

42 A imagem da mulher-criança já vinha sendo construída desde o século XVIII, mas é 
com o evolucionismo e a craniologia que ela se cristaliza. As idéias de Carl Vogt sobre sexo e raça estão no livro publicado em 1864, Lectures on Man: his place in creation and the history of the Earth. Ver Dijkstra (1988: 167).

43 Nordau dedicou seu livro a Lombroso, cujas idéias sobre o atavismo eram bem aceitas e respeitadas nos meios científico e cultural.

44 Dijkstra (1988: 218) comenta que Sexo e Caráter foi um livro de grande sucesso, sendo lido e comentado por leigos e acadêmicos, tendo sido traduzido para várias línguas.

45 Schopenhauer (1900: 135) diz que a inteligência masculina é obscurecida pelo amor a uma bela mulher, que, segundo sua definição, teria ombros estreitos, quadris largos e seria de estatura pequena.

46 Para o autor, quando uma mulher demonstrava interesse pelas artes, era com o único objetivo de agradar o homem. A ausência do sentido de justiça era o argumento do autor para se opor à participação das mulheres nos tribunais como juradas e a desconfiar do juramento das mulheres: "É impossível encontrar uma mulher verdadeira e sincera" (Schopenhauer, 1900: 133).

47 Ver Darmon (1991).

48 Esta idéia será muito utilizada pelos médicos obstetras e ginecologistas, como veremos nos capítulos seguintes. A discussão sobre a indiferenciação das mulheres estava na raiz da idéia de que todas as mulheres eram iguais, uma frase que se tornou uma espécie de ditado popular, mas que tem sua origem nestes textos evolucionistas.

49 Lombroso e Ferrero dizem (1923: 20-21) que o número de glóbulos vermelhos nas mulheres é inferior ao dos homens. Citando o fisiologista Hayem, as mulheres teriam 4.900.000 glóbulos vermelhos e os homens 5.500.000; ou então 0,05824 mg de ferro no sangue dos homens para 0,0499 mg no sangue das mulheres.

50 Comentando sobre a influência da raça e do clima na idade da menarca, Lombroso e Ferrero (1923: 34) citam a espantosa conclusão de um pesquisador italiano, Pagliani, afirmando que entre as jovens que menstruavam precocemente, aos 13 anos, metade eram loiras; aos 14 anos, mais da metade eram castanhas e aos 15 anos a maioria tinha cabelos escuros, o que 'provava' a precocidade sexual entre as loiras.

51 O restante do livro é dedicado ao estudo da mulher criminosa e à prostituta. A estrutura dos capítulos é semelhante à primeira parte, iniciando pelo comportamento animal e das raças 'primitivas' relativo aos delitos. Como no livro sobre os criminosos, Lombroso, agora juntamente a Ferrero, procura no corpo da mulher, os estigmas da criminalidade, recorrendo a diversas variáveis como o peso, a altura, o tamanho das mãos e dos pés, a cor dos cabelos e dos olhos, o tamanho do cérebro e dos órgãos genitais. A análise dos dados obedece ao mesmo procedimento analógico da primeira parte, sendo constantes as comparações de raça, gênero e classe social. Sobre as idéias de Lombroso e Ferrero a respeito da prostituta, ver Rago (1991). 


\section{A ciêncía Obstétríca}

Em 1903, o pintor vienense Gustav Klimt havia terminado o quadro A Esperança I, representando uma mulher grávida. O quadro causou polêmica e foi considerado obsceno, ficando numa espécie de reclusão, voltando a ser exposto em 1909 (Figura 2). O que um quadro com tal temática podia ter de ofensivo à moralidade burguesa? Para responder a esta pergunta tomemos um outro quadro, produzido por Renoir 17 anos antes. Apesar das diferenças estilísticas e culturais entre os dois pintores, ambos representaram a mulher, com a diferença que Klimt a retratou grávida, enquanto Renoir pintou sua esposa amamentando seu filho. Em ambos, o tema da maternidade está presente, seja na espera, seja na efetivação da ligação mãe e filho.

O quadro de Renoir, de 1886, tem como título Maternidade, ou Mulher amamentando seu bebêe (Figura 3). É um quadro em que as duas figuras principais foram desenhadas com grande realismo, destacando-se do fundo tipicamente impressionista, o que só acentua a definição das duas figuras. A mulher é bastante corpulenta, tem o rosto redondo e corado, e está dando o seio farto para o bebê roliço que brinca com os pés. Além do aspecto físico da mãe, chama a atenção seu olhar sereno e tranqüilo. É uma exaltação à maternidade centrada na amamentação, um ato de relevância moral, celebrado pela medicina de então como a maior demonstração do amor materno e a garantia de um filho, e futuro cidadão, saudável. Pensando nos diferentes discursos que exaltavam a maternidade, esse quadro é uma objetivação das idéias e valores a respeito dos papéis de gênero, do casamento, da família e, principalmente, da mulher. Como tal, apresenta uma visão idílica da maternidade, sem nenhuma referência à sexualidade ou aos momentos anteriores da gravidez e do parto; associando-a ao 'Jardim das 
Delícias', onde mãe e filho gozam da paz e felicidade para o deleite do pai observador. Tem-se, portanto, um quadro apaziguador da mulher e adequado às representações burguesas da feminilidade, tão divulgadas para o público de classe média da época.

Figura 2 - A Esperança I, (Klimt, 1903)

A representação de mulheres grávidas nuas não era comum na arte ocidental, especialmente no século XIX. Klimt rompeu com a regra do distanciamento cultural ao erotizar a gravidez, tema cercado de tabus, respeito, silêncio e mesmo devoção.

Fonte: Néret, 1944. National Gallery of Canada

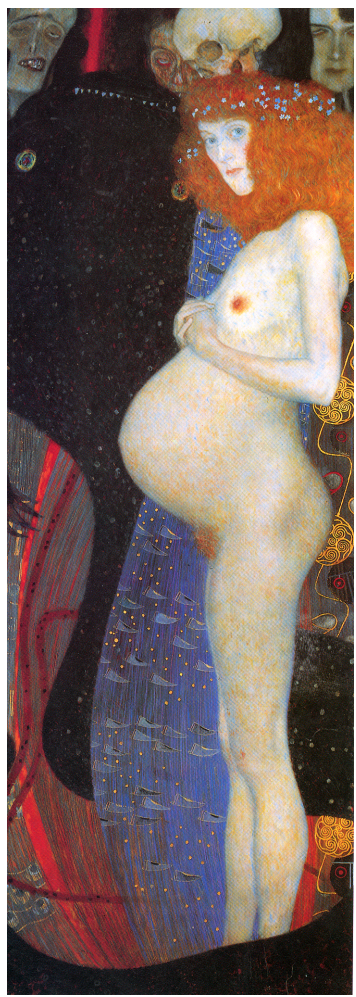

Pode-se entender o choque que o quadro de Klimt provocou ao representar uma mulher grávida nua. Há vários elementos inquietantes no quadro. Primeiro, o tema, pois não era comum a representação de mulheres grávidas na arte ocidental, particularmente nas artes plásticas do século XIX. A gravidez era um estado deveras associado à sexualidade e tratá-la plasticamente era um desafio não só estético, mas moral e cultural. Segundo, a nudez. O nu artístico era muito apreciado e divulgado na cultura burguesa, mas tinha suas regras para ser visualmente aceito. Embora os nus oitocentistas fossem bastante realistas, estabelecia-se o distanciamento entre a obra e os observadores, geralmente através da representação de alegorias de temas mitológicos e históricos ou de temas exóticos à cultura ocidental. Essa preocupação com a moralização da nudez foi muito bem abordada por Allaert (apud Bologne, 1990: 14): 
O nu artístico que visa apenas à representação da realidade, capaz de suscitar os maus sentimentos que se produzem à vista da nudez real, podem justamente ser vistos como um perigo para a moral pública. Mas se um artista emprega formas humanas para transmitir uma idéia não imoral, se a obra é capaz de atingir esta finalidade, não só ela nada terá que ofenda o pudor como poderá até adquirir um certo valor moral, no sentido que poderá suscitar o sentimento do belo, de natureza excessivamente moral.

\section{Figura 3 - Maternidade ou Mulher amamentando seu bebê} (Renoir, 1886)

\footnotetext{
Visão idílica da maternidade centrada na relação mãe-filho através da amamentação, ato celebrado pela moralidade e pela medicina como a expressão do amor materno.
}

Fonte: $\quad$ Os Impressionistas, 1991 (Coleção Particular, Nova Iorque)

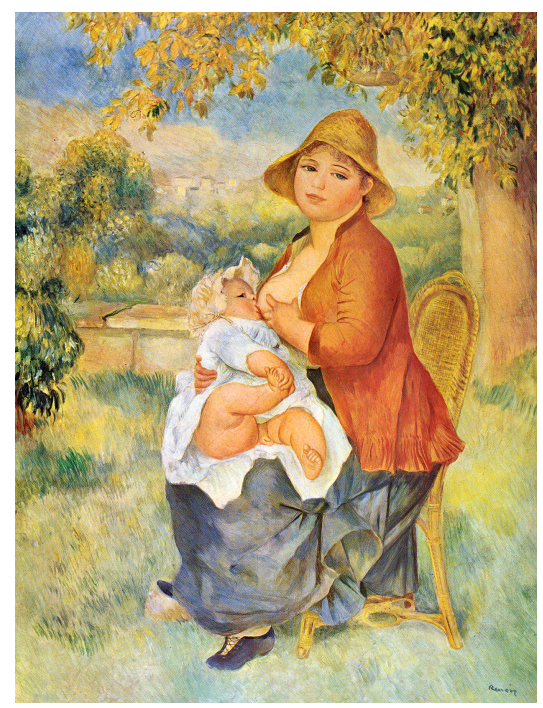

A jovem mulher representada por Klimt expõe seu ventre bastante volumoso de forma escandalosa para a época e para o ideal estético moralizante descrito por Allaert. Embora o quadro esteja repleto de simbolismo, o que chama a atenção é a nudez extremamente realista. Por fim, não há na representação nenhuma idealização da maternidade. A mulher olha diretamente para o observador, mas, diferentemente da doce esposa de Renoir, não transmite esperança ou felicidade, nem mesmo paz. Seu olhar é enigmático e sua sensualidade indisfarçável, longe, portanto, das representações da mulher-mãe.

Klimt rompeu uma regra cultural ao erotizar um tema que era cercado de respeito, silêncio e devoção. Representar uma mulher grávida nua significava quebrar o mito da reabilitação feminina pela maternidade e associar maternidade à sexualidade, algo que a religião e a medicina se empenharam em separar. Nesse sentido, a nudez do quadro Esperança I era obscena, insuportável e imoral. ${ }^{1}$ 
Essas duas imagens separadas por quase vinte anos são contemporâneas de uma crescente preocupação médica e social com a maternidade. Médicos, filantropos e religiosos uniram-se para dar melhores condições às mulheres pobres para que elas pudessem ter seus filhos. Os médicos do final do século XIX já conheciam melhor o mecanismo do parto e estavam equipados com instrumentos e técnicas cirúrgicas para resolver partos complicados. Os hospitais já não eram mais os espaços lúgubres e mal cheirosos que tanto pavor causavam às mulheres. Maternidades equipadas e organizadas sob o princípio da assepsia, voltadas principalmente para o atendimento de mulheres pobres e das classes trabalhadoras, começavam a se tornar indispensáveis nos centros urbanos. ${ }^{2}$

A mulher grávida e a parturiente tornaram-se o centro das atenções dos obstetras nesta fase. A obstetrícia era uma especialidade nova - nascida nas faculdades de medicina européias na primeira metade do século XIX - e ainda lutava para ser reconhecida, tanto no meio médico quanto para o público leigo, em especial para os maridos e suas esposas. Algumas mulheres já chamavam o médico-parteiro para atendê-las nos partos domésticos, mas a maioria delas, principalmente nas classes populares, ainda preferia contar com a presença da parteira, das parentas ou vizinhas, para socorrê-las em meio às dores e incertezas do parto. O período que começa nas últimas décadas do século XIX marca o início de uma campanha médica de transformação do parto num evento controlado pelos médicos e circunscrito ao espaço hospitalar; transformação esta que se efetivou somente na segunda metade do século XX, com a hospitalização do parto nos centros urbanos.

No entanto, a gravidez e o parto não foram assuntos exclusivos de uma camada letrada de homens. Vistos sob a perspectiva da história oficial da obstetrícia, esses assuntos só tiveram relevância com a entrada dos médicos num domínio que, até então, tinha sido exclusivo das mulheres. Contudo, a história do parto e da maternidade não se confunde com a história da obstetrícia, uma especialidade médica cuja história é contada como uma seqüência de sucessos e superação da ignorância, da brutalidade e da dor, fruto da ação e do conhecimento dos cirurgiões e médicos que, apesar das adversidades, se dedicaram a esses momentos da vida das mulheres. A gravidez, o parto e a maternidade eram experiências femininas, cuja história não tem marcos iniciais (não há 'mães' da obstetrícia como há 'pais') e não conta com registros escritos, muito diferente da obstetrícia, com sua bem estabelecida tradição escrita, que remonta à medicina antiga. 
As fontes médicas geralmente são bastante prolíficas, pois trazem algumas informações sobre as parturientes e parteiras, relatando, parcialmente, seus valores, comportamentos e práticas. No entanto, essas fontes dizem mais dos valores dos próprios médicos sobre o parto do que das experiências das mulheres, pois trazem mais informações sobre os partos complicados que eles atendiam do que a respeito dos partos naturais presenciados somente pelas parteiras. Tem-se, assim, uma visão parcial da gravidez e do parto nas sociedades pré-industriais, marcada somente pelos problemas e situações desesperadoras. O que a história das mulheres vem fazendo é utilizar fontes iconográficas, religiosas, demográficas e folclóricas a fim de obter um conjunto mais diversificado de informações a respeito das práticas e dos valores das mulheres sobre o corpo e os momentos da gravidez e do parto.

\section{O Parto: um assunto de mulheres}

Em um texto, Laget (1977) perguntava se o parto não seria um acontecimento alheio à história, circunscrito aos rituais fisiológicos e às experiências da dor e do sofrimento. A pergunta, respondida pela própria autora e outros pesquisadores, mostra que o parto é, antes de tudo, um evento social e, como tal, submetido a rituais, códigos e tradições, caracterizando-se, portanto, como um acontecimento histórico. O caráter lacunar e fragmentário das fontes é um problema que vem sendo contornado com instrumentos metodológicos, como a comparação e a analogia, que utilizam informações provenientes de outras especialidades como a arqueologia e a antropologia. A documentação disponível e os dados das pesquisas etnográficas são convergentes no que diz respeito à universalidade dos ritos do parto e da maternidade, bem como à existência de uma tradição feminina relativa a estes ritos.

As pesquisas arqueológicas e etnográficas informam que o ato da parturição é, na maioria das sociedades não-ocidentais, agrícolas e préindustriais, vivido solitariamente ou restrito a um grupo pequeno de mulheres que ajudam a parturiente. Os cuidados prestados à mãe durante e após o parto são reconhecidamente atribuições femininas que não chamaram a atenção dos médicos, a não ser quando o parto se complicava, colocando em risco a vida da mãe.

Se o parto foi um assunto de mulheres, como então explicar que os médicos escrevessem sobre ele, começando a construir um discurso 
autorizado sobre o corpo feminino? Segundo a análise que Rousselle (1984) fez dos discursos médicos do mundo antigo greco-romano, foram as mulheres mais qualificadas e experientes nas doenças femininas e nos assuntos obstétricos que forneceram informações aos médicos, que, por sua vez, as recolheram e divulgaram pela escrita. Assim, o Corpus Hipocraticum e os livros dos médicos alexandrinos do século II a respeito da obstetrícia integraram os conhecimentos empíricos das parteiras às teorias médicas sobre saúde e doenças, que, ao longo do tempo e pela falta de contato entre médicos e mulheres, foram perdendo o caráter prático, transformando-se num conhecimento teórico e especulativo.

A divisão de gênero desses conhecimentos é mais visível nos escritos de Soranos, médico grego. Esse médico viveu em Roma na primeira metade do século II servindo às classes dirigentes, especialmente às mulheres ricas. Com base nesta experiência, escreveu Ginecologia, um conjunto de textos sobre as doenças das mulheres e a obstetrícia. Nos capítulos relativos aos partos naturais, Soranos dirigiu-se às parteiras, indicando os preparativos, os cuidados com o local do parto, com o bem-estar da parturiente e do recém-nascido, além de trazer informações sobre a sociabilidade feminina ao referir-se aos rituais do puerpério, festividades organizadas e restritas às mulheres. Os capítulos relativos aos partos difíceis foram dirigidos aos médicos, já que era só nessas circunstâncias que eles atuavam.

Como os partos normais eram muito mais freqüentes que os complicados, pode-se dizer que na prática do atendimento as parteiras predominavam. Mas esta prática não se fundamentava apenas em uma divisão de trabalho; tinha origem na desqualificação do parto pelos médicos antigos que consideravam a obstetrícia uma prática vil e inferior associada à dor, ao sangue e às impurezas, sendo, portanto, um assunto a ser resolvido pelas próprias mulheres. Além da repugnância dos médicos, há que se destacar a importância da segregação sexual nas sociedades antigas e pré-industriais.

O interesse dos médicos pelas doenças das mulheres e pela obstetrícia não se restringia à ética ou aos imperativos profissionais da prevenção e da cura das doenças, mas obedecia também a uma razão política. Tanto na sociedade grega quanto na romana a importância da mulher era medida por sua capacidade em gerar herdeiros saudáveis. Na sociedade romana, principalmente no período imperial, o casamento e a geração de filhos eram assuntos da política dinástica e do Estado. A participação dos médicos foi de extrema importância e os textos que tratam das mulheres são 
verdadeiros manuais de fecundação, conforme explica Rousselle (1984), para que pudessem prevenir os problemas ou restabelecer a saúde das mulheres, ou seja, a capacidade de procriar.

Diferentes eram as razões que levavam as parteiras a exercer sua prática. Como geralmente as parteiras e as parturientes tinham a mesma origem social, compartilhavam das mesmas expectativas, valores e crenças em relação ao destino das mulheres em um mundo organizado e dirigido pelos homens, marcado pelo casamento e pela maternidade. As parteiras não só atuavam no momento do parto, mas providenciavam os preparativos, organizavam o local, cuidavam da alimentação e do vestuário da parturiente, participavam, junto com outras mulheres, dos preparativos ritualistas com seus amuletos, ervas, encantamentos, preces, enfim, todos os recursos mágico-religiosos que pudessem auxiliar o parto e afastar os malefícios. Após o parto, as parteiras continuavam prestando seus serviços até que a mulher estivesse em condições de retomar suas atividades cotidianas. Portanto, o papel das parteiras era muito mais complexo do que simplesmente aparar os recém-nascidos e cortar o cordão umbilical, abrangendo uma série de práticas culturais relativas à saúde, ao casamento, à maternidade e ao cuidado dos filhos, uma disponibilidade impensável para os médicos. ${ }^{3}$

Dessa forma, em um mundo rigidamente dividido em espaços físicos e culturais masculinos e femininos, o parto era um desses momentos vividos entre mulheres, como podemos verificar até mesmo pela etimologia da palavra inglesa para obstetrícia, midwifery, que no inglês antigo significa 'entre mulheres' ou 'com mulheres'. Na língua portuguesa, não existe um vocábulo para referir-se a essa prática milenar de assistir a uma mulher em trabalho de parto. Embora se traduza como obstetrícia, a tradução não dá conta do sentido original, pois esta é uma especialidade médica exercida por homens. ${ }^{4}$ Além disso, a palavra traduzida reduz o significado apenas para o atendimento do parto, excluindo todos os outros significados do que era estar 'entre mulheres' na ocasião de dar à luz.

Quando a história da medicina começou a ser escrita no século XIX, as práticas médicas antigas eram vistas com a mesma negatividade que as práticas populares da Antigüidade, principalmente da Idade Média, quando foram tratadas como representativas da ignorância e do obscurantismo. Nessa interpretação evolutiva da história, há o reconhecimento da ignorância dos médicos antigos sobre os assuntos relativos ao parto, mas a maior reação crítica fica para os leigos, especialmente para as parteiras das classes populares. 
Com exceção das parteiras profissionais dos séculos XVII e XVIII, os médicos historiadores viam as parteiras aldeãs como responsáveis pelas imperícias que resultavam na morte da mãe e da criança ou pelas mutilações, descrevendo-as como mulheres ignorantes, supersticiosas, descuidadas e apressadas. Na verdade, pouco se sabia sobre elas e sua clientela, pois essa narrativa histórica nos informa mais sobre como o parto deveria ser e a respeito de como os médicos conseguiram transformá-lo em um processo controlado por eles. A história médica da obstetrícia nos dá, por um lado, um quadro de ruptura com o que foi classificado como uma época de ignorância; por outro, a narrativa de um contínuo progresso das teorias e das práticas desenvolvidas pelos médicos obstetras, os 'pais' da obstetrícia.

As parteiras não entraram nesta genealogia porque representavam todo um conjunto de conhecimentos populares que, desde o século XVII, os médicos vinham tentando desqualificar para impor o seu conhecimento. Além disso, a história oficial da medicina era um instrumento necessário ao processo de profissionalização e construção do status do médico, no qual não cabiam concessões a outros saberes e práticas concorrentes. Bastavam as menções às parteiras instruídas e famosas que atendiam à nobreza e às mulheres das principais cidades européias. ${ }^{5}$

Muito diferentes são as conclusões que a história social da medicina chegou a respeito das parteiras, em particular as análises feministas produzidas na década de 70 do século XX. Invertendo as imagens negativas, essas pesquisas defendem as parteiras e afirmam que o parto conduzido por elas no espaço doméstico com a ajuda de outras mulheres era seguro e menos prejudicial às parturientes e aos bebês. No entanto, as pesquisas têm poucas evidências a respeito do parto nas sociedades tradicionais, abordando muito mais o processo de entrada dos médicos na cena do parto e a crescente substituição das parteiras pelos obstetras.

Em que pese uma certa tendência a ver na época anterior à obstetrícia científica uma época de ouro, em que as mulheres tinham o controle sobre o parto e suas relações se baseavam na solidariedade, a historiografia feminista muito contribuiu para uma visão política dos conflitos envolvendo médicos e parteiras; também revelou fontes desconhecidas, como documentos escritos pelas parteiras, que são evidências das experiências femininas com seus corpos e de suas relações com os médicos.

Ao reequacionar os termos dessa relação conflituosa, a história feminista do parto e da maternidade retirou de cena a oposição ideológica entre saber e superstição, para colocá-la no campo das disputas profissionais 
e da constituição de novos saberes sobre o corpo feminino que tiveram lugar a partir do século XVIII. Dessa forma, mostrou como a entrada dos médicos na cena do parto foi muito mais o resultado de uma relação de forças do que simplesmente a superação do obscurantismo pelo progresso do conhecimento médico.

\section{A Arte de Partejar: a entrada dos homens na cena do parto}

Mesmo sendo o parto um assunto de mulheres e permanecendo assim até o século XIX, alguns homens tinham certo contato com as parturientes, como os maridos que em certas situações ajudavam as esposas; os castradores de animais que na ausência de um cirurgião acabavam socorrendo mulheres agonizantes; ou os cirurgiões, chamados nos momentos em que o parto transformava-se num caso que exigia sua intervenção.

A obstetrícia é uma prática muito antiga, embora a presença masculina só ocorresse esporadicamente; no entanto, a entrada dos médicos na cena do parto natural e a transformação dessa prática em uma especialidade médica lucrativa não ocorreram antes do século XVIII e ainda assim de forma lenta e limitada em algumas classes sociais do meio urbano.

Geralmente, as práticas que requeriam contato com o corpo eram atribuições dos cirurgiões barbeiros, vistos com desprezo pela elite médica dos físicos. ${ }^{6}$ Quando uma mulher não conseguia dar à luz normalmente e as parteiras não resolviam o problema, depois de várias tentativas fracassadas só restava esperar pela intervenção divina ou então chamar um cirurgião.

Normalmente, os cirurgiões não tinham conhecimento sobre o parto e quase sempre eram tão ineficazes quanto as desesperadas parteiras. Há vários relatos 'escabrosos' de procedimentos realizados por ambos que devem ter contribuído para a má reputação dos cirurgiões e das parteiras não-profissionais. Embora os partos complicados não fossem muito comuns, com certeza devem ter deixado profundas impressões nas mulheres que viveram ou testemunharam cenas terríveis de parturientes que pereceram junto com seus bebês, contribuindo para o clima de medo e para a atitude de resignação perante a maternidade. ${ }^{7}$

Apesar da ignorância generalizada dos cirurgiões, nem todos eram indiferentes aos sofrimentos das parturientes. Muitos se interessaram pela obstetrícia e aprenderam com as parteiras sobre o parto natural para melhor compreender e interferir nos partos complicados. Foram estes 
cirurgiões os primeiros a retomar e a rever os conhecimentos disponíveis produzidos na Antigüidade.

Os manuais de partos que surgiram nos séculos XVI na Europa testemunham o interesse de alguns cirurgiões pela obstetrícia, recuperando a tradição médica greco-romana e divulgando os conhecimentos obstétricos que haviam caído no esquecimento durante a Idade Média. Autores como Eucharius Rösslin, Jacob Rueff, Scipione Mercurio e Ambroise Pare, entre outros, deram início ao que denominamos pedagogia obstétrica, direcionada às parteiras alfabetizadas que atuavam nas cidades, já que seus livros foram escritos para elas ou para cirurgiões sem experiência com operações obstétricas.

De uma forma geral, os manuais de obstetrícia dos séculos XVI e XVII são registros de uma prática que vai se tornando cada vez mais intervencionista. Os cirurgiões acabaram por desenvolver uma verdadeira obstetrícia patológica para a qual criaram todo um arsenal cirúrgico que muito contribuiu para a supremacia dos médicos-parteiros sobre as parteiras. Além das pinças, tesouras, dos fórceps, ganchos e perfuradores, também faziam parte da prática intervencionista as manobras obstétricas e as operações, como a embriotomia e a cesariana. Homens como Paré, Guilhemau, François Mauriceau e William Smellie tiveram seus nomes gravados na história da obstetrícia por terem desenvolvido práticas intervencionistas, criando novos instrumentos obstétricos e aprimorando métodos de diagnóstico. ${ }^{8}$

A crescente atuação dos cirurgiões entre as parturientes não pode ser explicada somente como uma moda que teria começado com o atendimento da favorita de Luís XIV pelo cirurgião Boucher, em 1663, mesmo porque o hábito de chamar médico-parteiro não se restringiu à nobreza da França. Tal processo se deve à conjunção de dois importantes acontecimentos que ocorreram entre os séculos XVII e XVIII. O primeiro foi a produção do conhecimento sobre as ciências biológicas, em especial sobre o corpo humano, como a anatomia e a fisiologia. A utilização das descobertas de Harvey (1616-1628) sobre a circulação do sangue representou uma verdadeira revolução para a cirurgia da época, da mesma forma que as dissecações realizadas com mais freqüência nos corpos humanos, inclusive em mulheres grávidas, abriram todo um campo de conhecimentos a respeito da gravidez. ${ }^{9}$ O segundo foi o crescente interesse pelo estudo do corpo feminino e os conflitos ideológicos das disputas profissionais entre cirurgiões e parteiras.

$\mathrm{Na}$ história oficial da obstetrícia, a versão da entrada dos médicos na cena do parto mostra os cirurgiões como indivíduos dotados de espírito 
investigador, que, apoiados nos estudos anatômicos, desafiaram o monopólio das parteiras e conquistaram um novo campo do exercício profissional. Graças aos conhecimentos anatômicos, os cirurgiões começaram a ser chamados para atender os partos naturais, aumentando a sua experiência com as observações. O Dr. Ernest Bumm, um dos mais respeitados obstetras alemães do final do século XIX, explica, no capítulo histórico do seu monumental Précis d'Obstétrique (1914), que a outra causa do progresso da obstetrícia francesa foi a criação de uma divisão de partos no Hôtel-Dieu no século XVII, que se ainda não servia para o ensino, contribuiu para dar experiência aos cirurgiões com o atendimento às mulheres pobres que se hospitalizavam. ${ }^{10}$

É interessante observar o vocabulário de Bumm (1914) ao referir-se à atuação dos cirurgiões e à ampliação de suas atividades como parteiros. Ele utiliza expressões militares, como se estivesse descrevendo realmente uma luta entre cirurgiões e parteiras ou entre a luz do saber e a escuridão da ignorância. Expressões como 'atacar' e 'conquistar' são usadas em sua análise para falar sobre a vitória dos médicos na luta pelo controle do parto; o autor também se refere aos instrumentos obstétricos, em especial ao fórceps, como uma arma do parteiro.

Esse vocabulário ainda utilizado no final do século XIX, sobre um processo histórico ocorrido 200 anos antes, é bastante adequado às imagens que cirurgiões, religiosos e funcionários públicos faziam a respeito da mortalidade materno-infantil, especialmente na França rural. Embora sejam escassos os dados, os registros de óbitos para algumas regiões da França, associados às primeiras estatísticas do Hôtel-Dieu, permitem afirmar que as denúncias não eram apenas resultado do preconceito contra as parteiras. ${ }^{11}$

Os tratados de partos multiplicaram-se durante o século XVIII, transformando-se em uma fonte valiosa para se entender como a produção do conhecimento a respeito da gravidez e do parto e a substituição da parteira pelo médico eram acontecimentos indissociáveis. Neles pode-se ler todo o processo de transformação do corpo feminino em um objeto de conhecimento, da mulher em paciente e, por fim, da parteira em auxiliar do médico.

As relações entre médicos e parteiras foram bastante estudadas e são bem conhecidas pela historiografia feminista. Geralmente, a questão gira em torno de acusações de incompetência, controle e usurpação de práticas da cultura feminina pela corporação médica. Contudo, esta questão não 
deve ser tratada no campo das oposições, nem se deve também alimentar uma visão romântica a respeito das parteiras. Médicos e parteiras podiam ser nocivos às parturientes, como também muito eficazes. Para se entender os interesses em jogo, é necessário analisar as condições socioculturais do momento de deflagração do conflito entre cirurgiões e parteiras.

Infelizmente, a maior disponibilidade de fontes testemunha apenas um dos lados da refrega. Desde a época de Rösslin, os médicos externavam opiniões desfavoráveis sobre as parteiras e esta atitude vai se manter quase inalterada até meados do século XIX. Poucos são os testemunhos de parteiras, mas eles existem. Algumas parteiras européias ficaram muito famosas por sua capacidade e perícia, publicando manuais de partos que foram tão ou mais importantes do que os manuais dos cirurgiões, ou então, deixaram registrada em diários a experiência de uma vida inteira dedicada à parturição.

O primeiro texto escrito por uma parteira foi Observations Diverses Sur la Sterelité, Accouchements et Maladies de Femmes et Enfants Nouveau-né, publicado em 1609 por Louise Bourgeois. O livro fez muito sucesso, sendo traduzido para o alemão e o holandês e muito citado pelos cirurgiões ingleses. Ela aprendeu o ofício com seu marido e com Paré, que foi seu mestre na arte, o que demonstra que muitas vezes parteiras e cirurgiões aprenderam uns com os outros. Tão importante quanto Louise Bourgeois foi a parteira alemã Justine Siegemund, que viveu no século XVII e também escreveu um livro expondo seus conhecimentos obstétricos. ${ }^{12}$

Esses livros mostram como algumas parteiras eram bastante experientes, tendo o mesmo nível de conhecimentos dos cirurgiões, senão até maior, além de informar sobre as estratégias de legitimação de seus trabalhos mediante as relações com os próprios cirurgiões, a clientela abonada e as autoridades religiosas.

Contudo, a maior parte delas não sabia ler e escrever, e mulheres como Louise Bourgeois e Justine atendiam uma clientela urbana e de alto poder aquisitivo. A prática das parteiras aldeãs e dos subúrbios pobres das cidades européias está perdida, como disse Gélis (1977). Pouco se sabe sobre elas, que atendiam a imensa maioria dos partos, a não ser que eram mulheres do povo cujo conhecimento vinha inteiramente da experiência, além de se cercarem de outros meios como a magia e a religião. Quando sabemos algo a seu respeito, são denúncias de imperícia e ignorância, relatadas não só pelos cirurgiões, mas também pelos manuais das parteiras qualificadas.

As fontes disponíveis mostram que não se pode falar das parteiras como se elas fizessem parte de uma mesma categoria social. Entre elas 
havia diferenças sociais e culturais importantes que as primeiras análises feministas não levaram em consideração. ${ }^{13}$ Segundo Shorter (1984), a questão não se restringe a saber se as parteiras eram mais ou menos incompetentes que os cirurgiões, mas sim o quanto elas estavam próximas dos conhecimentos disponíveis na época e se estavam habilitadas para atender emergências.

Desde a Idade Média, as parteiras de algumas regiões da Europa estavam organizadas em guildas e ficavam sob a supervisão de uma profissional mais velha e experiente responsável pelo controle das mais jovens e pela manutenção da qualidade dos serviços. Particularmente nas cidades alemãs, as parteiras tinham completa autonomia e eram muito qualificadas, mas nem todas eram membros das corporações e a grande maioria delas não vivia em cidades, mas sim no isolamento das aldeias e dos campos. Essas mulheres do povo eram, na maior parte, analfabetas e faziam as coisas por 'tentativa e erro', apoiadas na tradição. Geralmente, elas se saíam bem nos partos normais, mas nas emergências as coisas podiam fugir do controle e ficar muito ruins para as parturientes. Portanto, há que se ter clareza quanto à distinção entre as parteiras qualificadas e supervisionadas das cidades e as parteiras tradicionais do campo, as 'comadres'. Com certeza, as profissionais eram até mais qualificadas que os cirurgiões, entretanto, as críticas a respeito de seus perigosos procedimentos foram destinadas a elas, bem como às 'comadres' que atendiam as mulheres pobres.

As autoridades civis e religiosas não ficaram indiferentes às denúncias de imperícia das parteiras tradicionais. Desde o século XV as autoridades da Igreja já demonstravam preocupação com os aspectos morais e religiosos da prática das parteiras. Na verdade, o controle exercido pela Igreja fazia parte de uma atitude persecutória à cultura popular ante o universalismo da Igreja Católica e ao absolutismo do Estado Moderno, inteiramente antitéticos às práticas culturais que pudessem questionar ou se opor ao projeto de poder que começava a se estruturar e enrijecer a partir de então.

Desde o século XVII o controle das parteiras passou a ser exercido pelos médicos. É nesse momento que a cirurgia começou a ser mais reconhecida e respeitada, bem como se produziram cada vez mais manuais endereçados às parteiras, visando a transformá-las em divulgadoras do saber médico. A última fase de controle e supervisão deu-se no século XVIII com a disseminação das escolas de parteiras na Europa. 
A preocupação com a formação já era uma realidade para as parteiras qualificadas. Na metade do século XVIII, uma reconhecida parteira francesa, Madame Du Coudray, desenvolveu um curso para as parteiras do campo, formando mais de 5.000 delas com seu curso itinerante, baseado na demonstração com manequins de madeira. Por meio de cursos como esse, os conhecimentos dos manuais entraram no campo e nas regiões mais distantes dos centros urbanos; eram definidas informações não apenas sobre o parto, mas noções de higiene e cuidados com a puérpera e o recém-nascido.

Esses cursos práticos precederam o ensino oficial de partos e conviveram com esta última fase, quando então o Estado toma como sua a responsabilidade pelo ensino obstétrico. Gélis (1977) informa que os cursos e a criação de escolas de parteiras fazem parte da reação do Estado ao 'massacre dos inocentes', tão denunciado pelas autoridades provinciais, pelos religiosos e médicos. A mortalidade materno-infantil assombrava as consciências, e a necessidade de formar as parteiras foi defendida como parte de uma política natalista que se configurou a partir do século XVIII. ${ }^{14}$

Embora algumas parteiras e cirurgiões tenham trabalhado juntos e as profissionais tenham freqüentado cursos ministrados por cirurgiões, o conflito entre ambos se acirrou na disputa pela clientela, além do fato de que a entrada dos cirurgiões na cena do parto despertou reações moralistas. Apesar das críticas às 'comadres ignorantes', muitos homens e mulheres continuavam defendendo que o parto deveria ser conduzido pela parteira. A presença do cirurgião no momento do parto parecia, para muitos maridos, algo extremamente ofensivo para o pudor de suas esposas, como também havia uma certa desconfiança quanto à sinceridade das intenções dos cirurgiões, que podiam se aproveitar da situação para seduzir as mulheres. ${ }^{15}$

O mal-estar provocado pela presença do 'parteiro' foi sintetizado pela obra panfletária de Phillip Hecquet, publicada em 1708, com o título De l'Indécence aux Hommes d'Accoucher les Femmes. O autor recorreu à tradição das parteiras e usou argumentos religiosos para execrar o que ele e alguns de seus contemporâneos acreditavam ser uma imoralidade e uma indecência. ${ }^{16}$

Embora o atendimento dos parteiros nessa época fosse muito restrito à nobreza e às pessoas mais ricas das cidades, esta era uma novidade que ia cada vez mais se impondo entre as mulheres. As parteiras reagiram a esta invasão ao defender a qualidade de seu trabalho baseado na grande experiência que tinham. Outras, uma pequena parcela, deixaram por escrito suas opiniões a respeito dos cirurgiões. Entre estas se destaca Elizabeth Nihell, parteira inglesa contemporânea de Smellie, a quem endereçou suas críticas. 
Nihell defendia a arte obstétrica das parteiras, ressaltando o uso exclusivo das mãos, a paciência e a capacidade de julgar o melhor momento para intervir. Sua crítica principal era à intervenção com instrumentos obstétricos, que, em mãos apressadas e inábeis, podiam causar sofrimentos terríveis e danos irreparáveis. ${ }^{17}$ Ao fazer isso, Nihell não só alertava para os riscos de intervenções intempestivas, como também atacava o símbolo do poder dos cirurgiões parteiros: o fórceps. Além disso, pode-se perceber na crítica da parteira inglesa, um eco das reações mais gerais das classes populares ao uso de instrumentos e à experiência com os corpos humanos por parte dos cirurgiões. Quando Nihell escreveu, em 1771, os cirurgiões já estavam dominando a profissão em alguns segmentos sociais e haviam conseguido impor restrições às parteiras profissionais; primeiro, controlando a formação, e, por fim, dificultando o acesso às faculdades de medicina, aos conhecimentos e ao instrumental cirúrgico.

A invenção de instrumentos obstétricos como o fórceps deu-se paralelamente à entrada dos cirurgiões na cena do parto. O fórceps foi criado no século XVII pelos cirurgiões da família Chamberlen, na Inglaterra, e posteriormente aperfeiçoado por cirurgiões franceses e pelo inglês Smellie, o desafeto de Elizabeth Nihell. Embora fosse um invento importante na resolução de partos muito demorados, podia causar muito sofrimento para a mulher e mutilar a criança. $\mathrm{O}$ uso do fórceps em mãos inexperientes começou a gerar uma série de relatos de acidentes e alguns cirurgiões se opuseram ao uso freqüente deste e de outros instrumentos.

Dos dois lados do Canal da Mancha os cirurgiões dividiram-se entre aqueles que preferiam deixar o curso da natureza agir e os intervencionistas, para quem o uso dos instrumentos só valorizava a habilidade do cirurgião. Nihell e De la Motte, este último um famoso cirurgião parteiro contrário ao abuso dos instrumentos, perderam esta luta, pois apesar das reações moralistas e populares, foi a figura do cirurgião armado com seus instrumentos em luta contra os obstáculos do corpo que se impôs. Os cirurgiões iluministas divulgaram esta imagem, associando a prática obstétrica e o instrumental com a idéia de competência e superioridade em relação às parteiras. ${ }^{18}$

Além das demonstrações da habilidade armada pelos instrumentos, os cirurgiões divulgaram este novo campo de atividade profissional e de saber através dos livros. Após a segunda metade do século XVIII, houve uma grande produção de livros de obstetrícia, alguns extremamente complexos, com muita informação baseada na casuística e ilustrações cada 
vez mais realistas, como é o caso do trabalho de Hunter sobre o útero grávido anteriormente citado.

É evidente que o público para esses livros era pequeno, composto pelos cirurgiões, estudantes de medicina e pelas parteiras que freqüentavam escolas de parto; mas, na tradição iluminista, este saber, fruto da observação e da prática, era o símbolo de uma nova época, a Época das Luzes, que levaria à vitória da razão sobre a ignorância. O parteiro munido com seus instrumentos e com os tratados de obstetrícia se impôs sobre as parteiras como um homem que, além de conhecer o corpo feminino, representava a Ciência. A caricatura do sangrador vai se esvanecendo perante a imagem poderosa que se constrói de homens, como Baudelocque e Levret, na França, ou de Smellie e Hunter, na Inglaterra, à medida que a imagem do cirurgião competente passa a ser construída no processo de produção e institucionalização do saber médico.

Nesse processo, as parteiras formaram uma profissão de auxiliar do médico, este sim, o novo especialista em mulheres que surgia no século XIX. Com a divulgação dos cursos de partos na França, Inglaterra e Alemanha, as parteiras tornaram-se aliadas dos médicos, o que explica a boa convivência profissional entre ambos nas maternidades e o tom paternalista com que os médicos se referiam às suas auxiliares.

Cada vez mais presentes ao lado das parturientes, os médicos tornaram-se especialistas não só do parto, mas também da gravidez, do puerpério, da saúde e das doenças dos recém-nascidos, associando a experiência aos conhecimentos científicos produzidos nas principais faculdades de medicina européias; assim, formou-se um novo especialista no século XIX: o obstetra.

\section{A Ciência dos Partos: a obstetrícia científica do século XIX}

No antigo prédio localizado no Terreiro de Jesus, em Salvador, onde funcionou a Faculdade de Medicina da Bahia, encontram-se vários quadros de turmas de doutorandos, todos em madeira entalhada, com fotografias e homenagens. Alguns trazem gravuras com temas médicos, exaltando a arte de curar e a figura respeitável do médico. Em um desses quadros, uma jovem, esposa e mãe, encontra-se muito doente e abatida, sendo atendida por um médico idoso que, ajoelhado ao seu lado, toma-lhe o pulso. Ao lado do doutor e da doente estão o marido cabisbaixo e preocupado, os filhos 
ainda pequenos, uma mulher que parece ser a avó das crianças e uma serviçal. Todos os olhares se voltam para o conjunto médico-paciente, como que a esperar pela palavra do médico, cuja imagem representa autoridade, experiência a dedicação.

Essa gravura escolhida para compor um quadro de formatura dos jovens médicos baianos faz parte de um conjunto de representações pictóricas que foram produzidas a partir da segunda metade do século XIX na Europa, divulgando a imagem heróica e salvadora do médico. No Brasil, este gênero de pintura não se desenvolveu, mas na Europa e nos Estados Unidos há muitos quadros e gravuras do tipo, e é provável que a gravura escolhida pelos doutorandos baianos seja uma reprodução de algum quadro europeu. ${ }^{19}$

A pintura e a literatura do século XIX muito contribuíram para a divulgação da imagem moderna do médico: um homem respeitável, sábio, bom observador e, mais importante, confiável; alguém que podia entrar nos lares, conhecer os membros da família, tornar-se o confidente das mazelas e das misérias humanas, bem como ser uma espécie de educador dos corpos e dos sentimentos, um novo sacerdote, só que a serviço da ciência e da saúde.

A imagem do médico de família demorou quase um século para ser construída e dominar o imaginário a respeito do corpo, da saúde e das doenças, especialmente entre as classes mais altas e letradas. O médico de família tinha, além de suas credenciais profissionais que o habilitavam perante a clientela que podia pagar, as mesmas origens sociais e culturais de suas clientes, o que facilitou sua entrada nos recantos e segredos da intimidade familiar. No entanto, esta aproximação não foi uniforme e nem ocorreu ao mesmo tempo. Pode-se perceber melhor os efeitos do que é chamado de medicalização da sociedade em algumas camadas sociais, especialmente na burguesia, e em algumas regiões urbanas da França, Inglaterra e Estados Unidos. Mas, mesmo nestes países, vários grupos sociais e regiões mais afastadas das grandes cidades continuaram alheios à nova autoridade médica, mantendo seus costumes e recorrendo a outros profissionais da cura, como curandeiros, benzedeiros e parteiras nãoprofissionais. Países não-europeus como o Brasil, onde o ensino oficial da medicina só foi organizado no século XIX, são exemplos desta não uniformidade da medicalização da sociedade, onde a autoridade médica se impôs a uma pequena parcela da população - branca e endinheirada -, ficando a grande maioria a socorrer-se de outras práticas não regulamentadas, pelo menos até o início do século XX. 
Apesar dessas ressalvas, é inegável a importância social e cultural dos médicos na organização das sociedades modernas ao reivindicar para sua categoria profissional a autoridade, sustentada no conhecimento, a respeito de assuntos de interesse individual e coletivo; da ordem do privado e das políticas públicas.

Até o início do século XVIII o médico era um indivíduo que pertencia à elite, pouco afeito aos conhecimentos práticos (estes eram da alçada dos cirurgiões) e ao contato com os corpos doentes. Ainda presos à tradição escrita da medicina, os médicos ou físicos formulavam seus diagnósticos e terapêuticas baseados em analogias e na classificação das doenças, o que demonstra a formação excessivamente retórica e nada empírica dos médicos europeus. ${ }^{20}$

Por volta da segunda metade do século XVIII uma nova atitude começou a diferenciar o papel dos médicos. Trata-se de uma atitude fundamentalmente política, originada, em parte, da preocupação dos médicos com os alarmantes problemas de saúde pública, especialmente as epidemias que esporadicamente flagelavam as populações urbanas. Tal preocupação vem ao encontro de um crescente interesse dos estados modernos europeus pelas condições de saúde das populações, cada vez mais vistas como fontes das riquezas e do poder dos Estados e das nações. ${ }^{21}$

Rosen (1983) comenta como os médicos voltaram-se para os problemas de saúde pública visando a desenvolver ações controladoras, como a formação e a supervisão das parteiras, a regulamentação da profissão médica, obras de saneamento e a construção de hospitais. Desenvolveram igualmente uma série de regulamentos sobre o bem-viver das pessoas, incluindo os hábitos alimentares, o vestuário, o lazer, a higiene pessoal, a habitação, o ambiente de trabalho, a vida sexual, enfim, um conjunto bastante heterogêneo de regulamentações que foram incorporadas a um novo campo do saber e da prática médica que dominou o século XIX: a higiene.

A percepção de que o crescimento populacional e a riqueza das nações dependiam das boas condições de saúde foi determinante para o processo de profissionalização e legitimação do saber médico. Com a transformação dos problemas de saúde pública em assuntos administrativos dos Estados, o papel dos médicos passou a sofrer transformações - estes passaram a ser responsáveis não só pelo tratamento de indivíduos doentes como também pelas condições de saúde de toda a população. ${ }^{22}$

Percebe-se, portanto, uma ampliação considerável do campo da ação médica, antes restrita à nosologia e, doravante, cada vez mais extensiva e 
invasiva, já que seu objetivo tornara-se tão complexo com a medicina social. É justamente com a reorganização do campo da ação médica na segunda metade do século XVIII que se estabeleceram as condições necessárias para a entrada do médico no meio familiar. Mas, para que isso ocorresse, foi necessário vencer as resistências da autoridade paterna e o melhor caminho foi a verdadeira frente de batalha erguida contra a mortalidade infantil.

Donzelot (1986) comenta a respeito do florescimento de uma literatura médica a partir de 1760, voltada para a saúde das crianças. Afinada com as teorias econômicas e políticas da época a respeito do potencial econômico da população, a preocupação com a mortalidade infantil levou os médicos a coletar dados, estabelecer comparações, detectar as causas e propor políticas de saúde pública e de higiene familiar. ${ }^{23}$

Os médicos franceses foram os mais ativos nesta ação em direção à família burguesa. A questão problemática enfrentada pelos médicos era a aparente contradição entre as condições mais saudáveis de vida das crianças camponesas e a fragilidade das crianças burguesas das cidades que definhavam por causa da desatenção dos pais, ou melhor, das mães, e dos maus hábitos incutidos pelos criados que tinham mais contato com as crianças, segundo a interpretação dos médicos. O século XVIII foi palco de uma verdadeira batalha entre os médicos e aqueles que eles consideravam os maiores responsáveis pelos riscos à saúde infantil: os charlatões, as 'comadres sabichonas' e os criados.

Como parte desse discurso normativo e pedagógico estão a campanha em prol da amamentação e todo um conjunto de medidas higiênicas para a infância, reforçando os laços entre mães e filhos e entre os cônjuges no interior do espaço regenerado e saneado da família moderna. ${ }^{24}$

Textos médicos e leigos foram escritos especialmente para atingir as mulheres, almejando modificar-lhes os hábitos em relação ao cuidado dos filhos e transformá-las em clientes-confidentes, verdadeiras aliadas dos médicos na tarefa de moralizar as relações familiares, segundo um modelo prescrito pela higiene. A valorização da mulher como mãe foi, sem dúvida, uma estratégia bem-sucedida que contribuiu para a entrada do médico na vida privada, tornando-o uma espécie de conselheiro sobre vários aspectos da vida familiar. ${ }^{25}$

Ao tornar-se um aliado nos assuntos relativos aos filhos, o médico teve acesso a outros assuntos específicos das mulheres, como a gravidez, o parto, o puerpério e as queixas ginecológicas. A formação do obstetra, 
este especialista em partos, deve-se muito à experiência propiciada pela proximidade com as mulheres. No entanto, a constituição da obstetrícia como especialidade médica dependeu da conjunção de outros fatores que não apenas a transformação do status do médico, fatores estes que remetem para questões de ordem epistemológica que afetaram as formas de se conceber e de praticar a medicina.

Autores como Canguilhem (1995) e Foucault (1980b) abordaram as transformações epistemológicas que afetaram a medicina como conhecimento e prática no século XIX, especialmente Foucault, ao investigar o novo discurso médico fundado na experiência clínica. O autor aborda uma das questões centrais na relação entre a medicina clínica e as ciências biológicas - a soberania do olhar na investigação científica sobre o corpo humano - quando se propôs estudar a história dessa experiência baseada na visibilidade do corpo e na relação entre o visível e o enunciável.

A reorganização do conhecimento científico que aconteceu nas primeiras décadas do século XIX levou ao definitivo abandono das explicações especulativas sobre o corpo humano, transformando-o num cenário material e visível, um novo território cujas verdades eram acessíveis ao olhar atento do médico - que sabia reconhecer, em meio à confusão subjetiva da paciente, a linguagem dos sintomas - e ao olhar atento do cientista - que descobria as camadas do corpo, lançando um olhar em profundidade entre tecidos e órgãos, em direção ao núcleo da verdade.

No início do século XIX, especialmente na França, vê-se o surgimento do novo homem das ciências biológicas, que combinava o exercício da medicina com a pesquisa científica, empreendida nas salas de autópsias e nos laboratórios de anatomofisiologia. Alguns deles tiveram seus nomes definitivamente gravados na história da medicina moderna, como a tríade francesa de médicos-cientistas que são considerados os grandes nomes da fisiologia e da patologia: Xavier Bichat, François Magendie e Claude Bernard. ${ }^{26}$ A articulação entre a clínica e o laboratório foi a grande inovação destes médicos, com exceção de Bernard, que se dedicou exclusivamente à atividade científica.

A partir da década de 1830, com a introdução dos novos conhecimentos produzidos pelas ciências biológicas nos currículos das faculdades de medicina, bem como pelo crescente interesse dos professores pela medicina experimental, descortina-se um novo cenário no ensino e na prática da medicina, no qual se destaca o médico como intérprete dos 
sintomas dos corpos doentes, fortalecendo sua autoridade no decorrer do século graças à reorganização epistemológica da medicina, que, por sua vez, definiu o corpo como um objeto do seu domínio, um novo ponto de partida do saber e do exercício do poder. ${ }^{27}$

Essa importante mudança no campo do saber médico teve um impacto imediato na antiga arte dos partos. Os professores das faculdades de medicina que até então repetiam nas aulas os ensinamentos retirados dos velhos tratados de obstetrícia produzidos nos séculos anteriores - sem ter nenhum interesse pelo ensino da prática - foram sendo substituídos por médicos imbuídos da necessidade de mudanças radicais nesse campo da medicina. Para isso, atacaram em duas frentes: primeiro, na reestruturação do ensino; segundo, na constituição de uma especialidade com objeto e vocabulário próprios, e com acesso aos espaços hospitalares, que, por sua vez, foram adequados para atender às demandas médicas, reforma esta que resultou na criação das maternidades na segunda metade do século XIX.

Embora o ensino da arte dos partos fosse muito precário, alguns poucos cirurgiões ingleses e franceses vinham, desde meados do século XVIII, dando cursos para os estudantes de medicina e para as parteiras. No entanto, nem todos os alunos freqüentavam tais cursos, ficando a grande maioria apenas com informações vagas e exclusivamente teóricas, sendo bastante comum a existência de médicos que terminavam seus cursos sem nunca ter assistido a um único parto, a não ser aqueles partos fictícios praticados por professores em manequins de pano ou madeira. ${ }^{28}$

Essa situação começou a mudar primeiramente na Escócia e na Inglaterra, países precursores no ensino da obstetrícia, onde ministravam aulas os mais famosos e respeitados parteiros da época como Smellie e Hunter. ${ }^{29}$ Cabe salientar que, em relação ao continente, o ensino ministrado pelos médicos e cirurgiões escoceses e ingleses era bastante avançado para a época porque, além da preocupação com a formação prática nos hospitais, homens como Smellie e Hunter tinham conhecimentos aprofundados de anatomia e fisiologia da gravidez e do parto, produzindo livros e material didático como atlas anatômicos muito detalhados e ricamente ilustrados, com um realismo espantoso se considerarmos a precariedade dos instrumentos óticos e dos procedimentos de diagnóstico. ${ }^{30}$

Na França, o ensino da obstetrícia foi oficializado no início do século XIX, no período napoleônico, com a criação da Cadeira de Partos, Doenças das Mulheres Paridas e das Crianças Recém-Nascidas, ministrada pelos 
mais famosos cirurgiões franceses da época, entre eles Baudelocque, talvez o primeiro cirurgião que tenha se dedicado exclusivamente à obstetrícia, cujo tratado L'Art des Accouchements, publicado pela primeira vez em 1789, já alcançara a 50a edição em $1815 .^{31}$ A obstetrícia francesa tornou-se o modelo para todos os outros centros de ensino médico até o final do século XIX, quando então a Alemanha e a Inglaterra passaram a fornecer um novo modelo para os campos da obstetrícia e da ginecologia. O ensino ministrado pela Cadeira de Partos nas faculdades de medicina de Paris e de Montpellier foi reproduzido em outros países, entre eles o Brasil, onde a primeira Cadeira de Obstetrícia tinha exatamente o mesmo nome francês.

O ensino oficial da obstetrícia pode ser analisado pelo impacto das novas informações produzidas pelas ciências biológicas, pela reação política do governo francês à mortalidade materno-infantil, mas não se pode esquecer que a oficialização do ensino foi contemporânea às publicações médicas sobre a natureza feminina que vinham sendo produzidas desde meados do século XVIII. Ao estabelecer a natureza física da mulher como fundamento de seu papel na sociedade, os médicos defenderam a necessidade de um ensino voltado para a especificidade reprodutiva do sexo feminino, bem de acordo com o ideário rousseauísta difundido entre médicos, intelectuais e mulheres letradas que viam no exercício da maternidade a redenção moral do seu sexo. ${ }^{32}$

Na mesma época em que se organizou o ensino obstétrico, vários pesquisadores franceses e alemães dedicavam-se a compreender os mistérios da reprodução humana. Se ainda não era possível entender como ocorria a fecundação, os estudos anatomofisiológicos do embrião humano forneceram elementos importantes para o exercício da obstetrícia, em especial para o conhecimento do processo da gravidez.

A gravidez não era, até então, um assunto de domínio dos médicos parteiros, pois o que hoje conhecemos como atendimento pré-natal, que é o acompanhamento clínico da mulher grávida, era um conceito desconhecido até meados do século XIX. A gravidez, assim como a maioria dos partos, continuava a ser um assunto de mulheres, cercado por interdições e pudores que muito lentamente foram cedendo conforme o médico foi se tornando o responsável pela saúde dos membros da família.

Com o ensino oficializado, tornou-se imperativo para os médicos ampliar seu campo de investigação, afinal o bom termo de um parto dependia dos conhecimentos clínicos da parturiente. Dessa forma, começou a se constituir a obstetrícia científica, acompanhando um movimento 
circular de conhecimentos que foi do parto para a gravidez e desta para o período conhecido como puerpério, englobando o parto e o pós-parto, bem como o atendimento ao recém-nascido.

O interesse médico pelo binômio gravidez-parto resultou em outra importante inovação no ensino médico com a criação da Cadeira de Clínica Obstétrica ou Clínica de Partos, na Faculdade de Medicina de Paris na década de 1830, inovação esta que depois foi copiada por outros centros de ensino médico. As duas cadeiras, teórica e prática, completavam-se, dando aos estudantes de medicina a oportunidade de aprender nas aulas teóricas a fazer diagnósticos, a reconhecer anomalias e a proceder no momento do parto, enquanto nas aulas de clínica podiam observar os ensinamentos do professor, acompanhando o atendimento às grávidas e puérperas na enfermaria de partos.

No entanto, mesmo com essa inovação e com o esforço e a fama dos professores, percebe-se, pela leitura dos tratados publicados na época, que havia ainda muita resistência entre os próprios médicos quanto à necessidade de uma especialidade médica voltada para a gravidez e o parto. Também há referências quanto às dificuldades para atender demandas do ensino prático, principalmente na França, onde, apesar do atendimento prestado no Hôtel Dieu e no hospital Saint Louis em Paris, e em outras cidades como Montpellier, Marselha e Estrasburgo, efetivamente os alunos pouco aprendiam, ora por falta de orientação, ora pelos impedimentos colocados pelas parteiras e parturientes que consideravam indecente a exposição das mulheres aos estudantes. ${ }^{33}$

Um crítico a esse estado de coisas foi Velpeau, professor de clínica cirúrgica da Faculdade de Medicina de Paris, cujo tratado foi utilizado por várias décadas, tendo publicado outros trabalhos de obstetrícia e cirurgia na década de $1830 .{ }^{34}$ No prefácio do Traité Complet de l'Art des Accouchements, de 1835, o autor defende o caráter científico da obstetrícia, dizendo que a fisiologia era a sua base, o que contribuiu para destruir as imagens preconceituosas e vulgares do parteiro diante do médico hábil e instruído nos misteres das ciências. Explica que seu livro fora produzido a partir da leitura de outros médicos e de sua própria experiência atendendo partos na maternidade da cidade de Tours e sua clientela particular.

Refutando a opinião de leigos e de colegas de profissão que não davam muita importância à 'ciência dos partos' ${ }^{135}$ por acreditarem ser o parto um acontecimento simples, um assunto de mulheres, Velpeau explicava que os problemas de natureza obstétrica eram comuns e necessitavam da atenção 
médica especializada em anatomia, fisiologia, patologia, embriologia e cirurgia, conhecimentos estes que ele possuía. É interessante observar a construção do seu argumento em defesa da ciência dos partos. Como bom racionalista, Velpeau foi buscar na história a justificativa para sua ciência. Equacionando ciência com grau de civilização, o autor explicava que nos períodos remotos da história da humanidade, entre os povos bárbaros somente as mulheres atendiam às parturientes. Com o progresso da civilização, os cirurgiões passaram a atender os partos, o que o levou a concluir que a arte dos partos deveria acompanhar as transformações científicas, vindo a tornarse uma ciência produzida exclusivamente pelos médicos, que seriam assistidos por parteiras treinadas e submetidas à sua autoridade.

Como professor, Velpeau atacou veementemente os obstáculos ao ensino prático. Na época em que escreveu seu tratado, tomou como modelo o ensino médico da Inglaterra, onde os alunos tinham aulas práticas orientadas pelos professores. Apesar dos espaços hospitalares disponíveis na França, parece que as parteiras ainda tinham bastante autoridade para não permitir o acesso dos estudantes às salas de parto que ainda não estavam sob o controle dos professores de clínica obstétrica. Velpeau defendia a existência de uma clínica de fato, confiada a um professor, mas seu desejo maior era a construção de maternidades, espaços hospitalares exclusivos à clínica obstétrica, ao ensino e à pesquisa. Segundo o autor, somente com uma instituição desta natureza a França poderia recuperar "o brilho que teve sem perder o lugar de honra entre as nações científicas e liberais" (Velpeau, 1835: CV). Velpeau anunciou a direção que a nova especialidade tomou no decorrer do século XIX: a organização do ensino teórico e prático e a hospitalização do parto com a criação das maternidades.

Mesmo enfrentando resistências consideráveis, ${ }^{36}$ a ciência dos partos foi uma das primeiras especialidades médicas a se constituir, sendo definida como o conjunto de conhecimentos relativos à reprodução da espécie. Com esta definição, os obstetras circunscreveram o tema da reprodução aos fenômenos da gestação e da parturição, já que pouco ou quase nada se sabia sobre a concepção. Ou seja, foi para os fenômenos que ocorriam no corpo feminino que as atenções e os olhares dos estudiosos se direcionaram. Toda a grande produção do conhecimento obstétrico, divulgada em livros e artigos médicos, ocorrida durante o século XIX, tem como objeto o corpo feminino, que foi minuciosamente inquirido, observado e representado. 
A reprodução da espécie tornou-se um assunto de extrema importância para os médicos e, devido ao papel desempenhado pela mulher nesse processo, era necessário conhecê-la, bem como as transformações que ocorriam no seu corpo durante a gravidez e o parto. A perenidade do grupo, da raça, da espécie ou da sociedade - variações conceituais para a idéia da existência humana - dependia da capacidade do corpo feminino em gerar a vida, o que explica a universalidade de mitos e crenças sobre a gravidez. A obstetrícia científica apoderou-se deste processo ao transformar a gravidez e o parto em fenômenos essencialmente naturais, observáveis e passíveis de controle, rejeitando qualquer explicação sobrenatural a respeito da geração humana. O que ainda não se podia explicar, acreditavam os médicos, seria futuramente explicado com o progresso da Ciência.

Não se pode entender a constituição da obstetrícia sem acompanhar o engendramento de uma nova relação entre o saber médico e a representação do corpo feminino. Construir um saber sobre a gravidez e os partos naturais exigiu dos médicos a reorganização do método de investigação do corpo da mulher, fundado no que Foucault (1986) chamou de princípio da visibilidade obrigatória. O saber médico deixou de ser apenas uma interpretação dos sintomas ao estabelecer a relação entre o que era visto (os signos do corpo) e o que era enunciável no diagnóstico e na projeção futura do prognóstico. Dessa forma, o conhecimento da gravidez e do parto dependia da visibilidade do corpo feminino, que, por sua vez, exigiu o aperfeiçoamento técnico dos exames.

Os tratados de obstetrícia do século XIX descrevem os novos procedimentos médicos que combinavam conhecimentos anatômicos com o exame físico da mulher. Assim, a obstetrícia procurou colocar em prática a máxima do conhecimento científico de então - saber para agir -, construindo um saber institucionalizado a respeito do corpo da mulher e acessível apenas àqueles que pertenciam ao círculo de iniciados e que dominavam o vocabulário e as práticas profissionais. ${ }^{37}$

Muito embora os médicos das épocas anteriores tenham escrito sobre a mulher, a gravidez e, em especial, sobre os partos difíceis, o alcance daqueles saberes era muito restrito, tanto entre os médicos como entre a clientela feminina. A prática da medicina anterior ao século XIX tinha a concorrência de outros recursos curativos e, como foi comentado anteriormente, a obstetrícia ainda era uma prática exercida quase que exclusivamente pelas parteiras. Além disso, os conhecimentos científicos produzidos ao longo do século XVIII sobre a diferença sexual sobrepunham-se, com freqüência, a 
um imaginário eivado de crenças sobre os poderes secretos e maléficos dos corpos femininos.

A constituição da ciência obstétrica no século XIX significou uma alteração profunda tanto no que diz respeito ao estabelecimento das competências quanto no que diz respeito à construção de um saber específico sobre as capacidades reprodutivas das mulheres como até então não fora possível. Com a ciência obstétrica e a objetivação do corpo feminino, casos como o nascimento de sapos, coelhos e outras estranhezas produzidas pelo corpo feminino passaram a freqüentar as páginas do anedotário popular e das caricaturas, enquanto os tratados de obstetrícia tornavam-se a fonte autorizada a respeito desse corpo e dos mistérios da reprodução da espécie.

Embora apresentem algumas variações quanto à organização dos temas abordados, todos os tratados fazem o mesmo percurso analítico: descrição do corpo feminino, gravidez, parto normal, parto complicado, operações obstétricas, problemas puerperais e cuidados com o recémnascido. Grande parte dos conhecimentos disponíveis vinha das salas de autópsia que foram bastante importantes para entender o desenvolvimento fetal e o mecanismo do parto. No entanto, o aspecto preventivo da obstetrícia dependia da relação clínica com as mulheres, coisa que não podia ser feita com cadáveres, mas somente por meio de exame minucioso do corpo vivo.

O exame obstétrico não era totalmente uma inovação. Parteiras faziam o exame para diagnosticar a gravidez e o parto muito antes de os médicos se interessarem pelo assunto. A diferença está no objetivo e nos métodos. As parteiras respondiam às demandas de suas clientes para saber se estavam grávidas ou para ajudá-las no momento do parto, sendo o exame apenas uma decorrência do exercício profissional. Para os médicos, o exame era uma forma de saber construído pela articulação do olhar, do tato e da audição - sentidos que foram ampliados com a invenção dos instrumentos de diagnóstico.

Conhecer o corpo feminino foi o primeiro passo para a construção desse tipo de saber indiciário produzido pelo exame, e isto significava recortá-lo como individualidade e objetivá-lo no interior de um novo campo do saber que o tornasse inteligível; um corpo dócil, sujeito às manipulações, às análises, a ser utilizado e aperfeiçoado, de acordo com a definição de Foucault (1986). Nesta direção, a obstetrícia se constituiu como um saber anatômico, lançando um olhar em profundidade para o interior da pélvis 
feminina, dissecando o útero, os ovários, as trompas, os músculos e os ossos. Este conhecimento em profundidade teve um duplo significado: por um lado, definiu a feminilidade como algo visível e localizado na pélvis; por outro, tornou-se uma espécie de conhecimento projetivo a ser utilizado pelo médico no exame clínico.

O olhar médico volta-se igualmente para a superfície do corpo, principalmente para diagnosticar a gravidez. As dificuldades eram imensas, pois, além das dúvidas quanto a este tipo de diagnóstico, não era comum o médico realizar exames desde o início do processo, devido aos pudores femininos e dos próprios médicos. ${ }^{38}$

Figura 4 - Dr. William Clysson (Winthrop Chandler, 1780)

Posando, dr. Clysson mostra como, inicialmente, a relação entre o médico e a paciente era mediada por fortes impedimentos à visão, prevalecendo o princípio do "toque, mas não olhe" com a finalidade de preservar os pudores de ambos os lados.

Fonte: Lyons, 1987. (Ohio Historical Society, Campus Martius Museum, Marietta, Ohio)

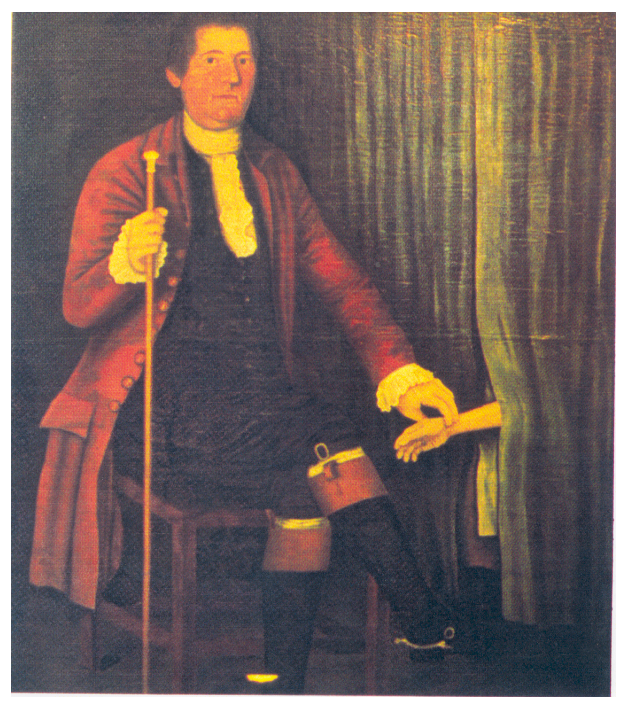

A Figura 4 mostra como o simples procedimento de tomar o pulso de uma paciente era cercado de interdições, o que certamente dificultava a formulação dos diagnósticos. Esta imagem também representa a linha de conduta dos médicos, anterior à medicina clínica, baseada no princípio 'toque, mas não olhe', que foi profundamente alterada ao longo do século XIX com a articulação entre o tato e o olhar.

A aceitação dos exames obstétricos deu-se com o trabalho de convencimento dos médicos junto às suas clientes, impondo lentamente 
sua autoridade ao associar a necessidade de ver com a idéia de prevenção e segurança para a mulher e seu filho. ${ }^{39}$ No entanto, a idéia de uma obstetrícia ocular não foi facilmente aceita por todos os médicos, pelo menos até a metade do século XIX. Isso se explica pelas origens da obstetrícia que esteve associada à idéia de arte, de ofício manual. Efetivamente, num parto natural, não há muito que fazer a não ser esperar o tempo da natureza. O papel da parteira ou do médico era aparar a criança, separá-la da mãe e prestar os cuidados subseqüentes. Nestes casos, as mãos eram os únicos instrumentos necessários. Para alguns médicos, o recurso do olhar era secundário já que sua arte dependia muito mais das mãos e da habilidade em saber usá-las nos exames e nos partos.

A exploração manual como método para estabelecer o diagnóstico da gravidez e do parto foi divulgada amplamente nos manuais e tratados de obstetrícia desde o século XVIII. Este método aparentemente simples passou a ser chamado de palpação abdominal e no início do século XIX era ensinado nas faculdades de medicina e praticado amplamente pelos médicos entre suas clientes. ${ }^{40}$ Com este procedimento, evitava-se o olhar direto sobre o corpo preservando-se, assim, os pudores femininos e dos próprios médicos.

Com a incorporação dos métodos da ciência experimental na obstetrícia, o princípio do 'toque, mas não olhe' foi considerado ultrapassado e um entrave ao desenvolvimento da especialidade, que tinha como objetivo ser a ciência dos partos. O aperfeiçoamento dos diagnósticos e o controle sobre o processo da gravidez e do parto dependiam de uma visão desimpedida do corpo feminino, inserindo-o num regime de visibilidade que ia dos níveis mais profundos do corpo até o nível da superfície corporal, um novo território que foi explorado e mapeado pela ciência obstétrica. Pela primeira vez na história da medicina, o corpo feminino tornava-se visível e inteligível.

Seguindo o modelo da anatomia patológica no qual o espaço corporal é descrito minuciosamente, a obstetrícia também procurou aplicar o mesmo rigor científico para conhecer seu objeto. Livros como o de Velpeau (1835) passaram a relacionar o texto minucioso e descritivo às imagens cada vez mais realistas das estruturas do corpo da mulher. Suas imagens são de observações retiradas da dissecação, em que a bacia feminina é analisada com precisão matemática e os órgãos genitais expostos detalhadamente. Contudo, essas imagens não são meras ilustrações do texto, mas descrições - elas ensinam a ver, integram o conhecimento e estabelecem uma relação entre o corpo-objeto e o olhar do sujeito-observador. 
A representação dos corpos de mulheres grávidas autopsiadas inseriu no campo visual do conhecimento o que até então era invisível e apenas imaginado. Na Figura 5, cujo título é Femme a Terme, vê-se a imagem de um corpo descoberto, revelado e exposto ao olhar na sua inquietante passividade. Nela, destaca-se o tema do desvelamento, que é tanto metafórico quanto real. Como metáfora, o desvelamento do corpo significa um procedimento para chegar ao âmago da verdade sendo com freqüência representado pela imagem da mulher descoberta. ${ }^{41}$ Como prática, o desvelamento faz parte de um novo direcionamento do olhar médico para o interior do corpo, proporcionado pela dissecação; começa pelo afastamento da roupa ou do pano que encobre o corpo materno, representado pelo seio e pelo ventre volumoso. Mas, o olhar vai mais fundo e outras camadas de tecido (orgânico) são afastadas para mostrar o interior do corpo com todos seus detalhes. ${ }^{42}$

Figura 5 - Femme a Terme

O olhar desimpedido do médico revela, pela autópsia, o interior do corpo grávido, integrando na mesma imagem conhecimentos anatômicos e obstétricos, inserindo no mesmo campo

visual o que até então era apenas imaginado.

Fonte: Velpeau, 1835. Paris: J.B.

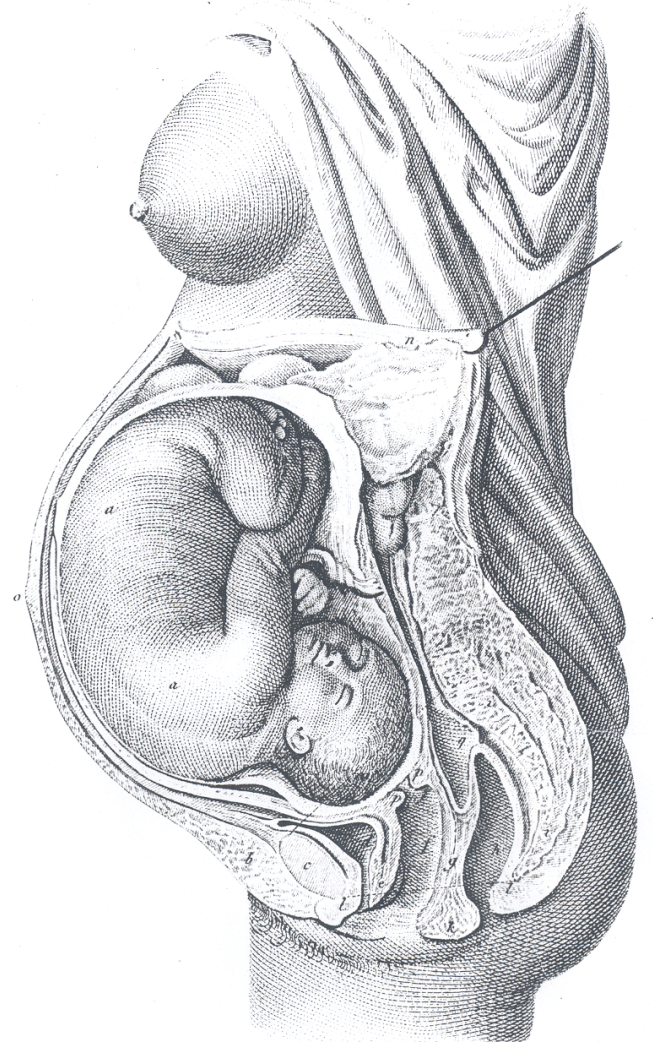


Essa imagem introduz outro tema que esteve cada vez mais associado às representações médicas do corpo feminino: o realismo. O objetivo da imagem é revelar a posição do feto e sua relação com as partes do corpo materno no final da gravidez. No entanto, o detalhe do pano que descobre o seio não dissecado estabelece um contraste com as estruturas anatômicas, criando no observador a convicção de que se trata de um corpo real, que a imagem recria o corpo tal como se apresenta no final da gravidez. ${ }^{43}$

Além da adição do pormenor, o realismo de imagens médicas como esta confirma o propósito da investigação científica em reproduzir com exatidão o real, com base na convicção de que somente o que é capturado pelo olhar pode ser conhecido. Dessa forma, quanto mais observado, analisado e descrito o corpo feminino, mais real ele parecia para os médicos, mais conhecido e controlado ele se tornava.

Mas não foram somente os corpos autopsiados os objetos do conhecimento obstétrico. Os exames em mulheres grávidas forneceram elementos até mais importantes para a obstetrícia do que a anatomia. O mesmo princípio da visibilidade obrigatória se aplicou ao mapeamento do corpo vivo examinado. Cada sinal foi devidamente observado, descrito e classificado, constituindo um arquivo de informações sobre a mulher no exercício de suas funções reprodutivas. A suspensão da menstruação, as alterações no volume e na pigmentação dos seios e as informações fornecidas pela própria mulher por meio da anamnese tinham valor relativo para os médicos. Na constituição da obstetrícia científica, as informações mais importantes eram aquelas fornecidas pelos métodos mais objetivos das mensurações pelvimétricas.

A pelvimetria foi uma técnica que começou a ser desenvolvida no século XVIII para conhecer os diâmetros da bacia, tendo em vista os problemas que os estreitamentos ósseos podiam trazer para o parto. As medidas podiam ser tomadas com as mãos, mas, na busca da precisão, foram inventados os pelvímetros, que passaram a fazer parte do instrumental obstétrico no século XIX. Como topógrafos, os obstetras passaram a medir as distâncias dos ossos da bacia, definindo padrões de normalidade e classificando as anomalias.

Nessa direção, os obstetras europeus nada deviam, em termos de rigor, de objetividade e de espírito criativo, aos seus congêneres de outras especialidades médicas que se constituíram na mesma época. Se recorrermos à história da medicina, veremos que especialidades como a obstetrícia, a cardiologia, a ginecologia, entre outras, definiram seus campos de saber 
ao mesmo tempo em que conseguiram transformar as doenças em entidades clínicas, isto é, fenômenos patológicos que podiam ser submetidos à análise mediante o recurso de instrumentos de medida e de observação dos corpos. A invenção de instrumentos de exame faz parte da experiência clínica em aperfeiçoar a análise dos dados obtidos com as medidas, em torná-los uma representação matemática da normalidade.

Desde o final do século XVIII a quantificação tornou-se uma prática cada vez mais generalizada nas ciências biomédicas. A craniologia talvez seja o melhor exemplo de aplicação das medidas e da estatística no conhecimento do corpo humano, estabelecendo os parâmetros para as comparações raciais e sexuais a partir das medidas do crânio e do volume do cérebro. ${ }^{4}$

Participando do mesmo ímpeto mensurativo dos corpos humanos, a obstetrícia criou a mulher pélvica, uma representação bastante apropriada não só pela ênfase dos estudos nesta região do corpo, mas também pelo significado que a pélvis teve na definição da feminilidade para o discurso médico. O fisiologista alemão Karl Burdach (apud Telles, 1930) definiu-a como o "laboratório da gestação", ${ }^{45}$ uma expressão que, com certeza, os obstetras do século XIX deviam concordar. Se a grande função natural da mulher era a maternidade, os médicos encontraram no "laboratório da gestação" ou, segundo a linguagem mais poética de Michelet, na "profunda taça de amor" (1985: 62), a nova e universal medida da feminilidade.

Levret foi o primeiro a fazer uma representação geométrica da pélvis feminina em 1761.46 No entanto, o exame pelvimétrico tornou-se um procedimento clínico largamente utilizado após a publicação do famoso tratado de Baudelocque, que se aprofundou nos estudos anatômicos da pélvis, criando o primeiro pelvímetro - o compasso de Baudelocque - que foi utilizado até o século XX.

Devido à forma da bacia e suas ligações com a coluna vertebral e outros ossos, os obstetras fizeram várias medidas, criando variedades de exames e de pelvímetros adequados a cada uma delas. O resultado de tantas medidas foi uma representação geométrica da pélvis, obtida pela exposição do corpo feminino em diferentes posições para que todos os diâmetros fossem estabelecidos. ${ }^{47}$

Os exames obstétricos, como a palpação abdominal e a pelvimetria, são procedimentos clínicos fundamentais para a transformação do corpo feminino em objeto do saber e alvo do poder, de acordo com Foucault (1986); observando as imagens dos exames nos livros de obstetrícia, vê-se com melhor clareza como se deu esta transformação. 
Figura 6 - Palpação abdominal

As mãos exploradoras do médico percorrem a superfície do abdômen grávido para certificarse da posição do feto.

Fonte: Depaul, 1876. Paris.

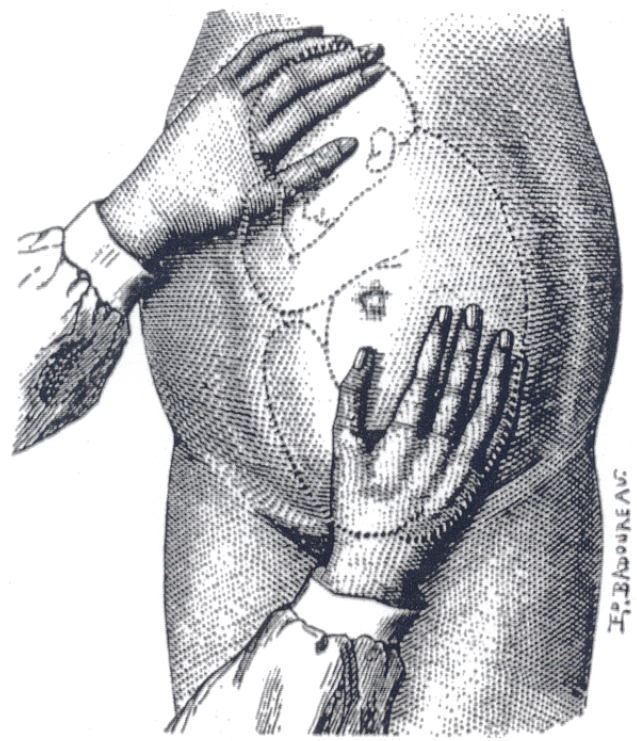

Figura 7 - Pelvímetro de Baudelocque

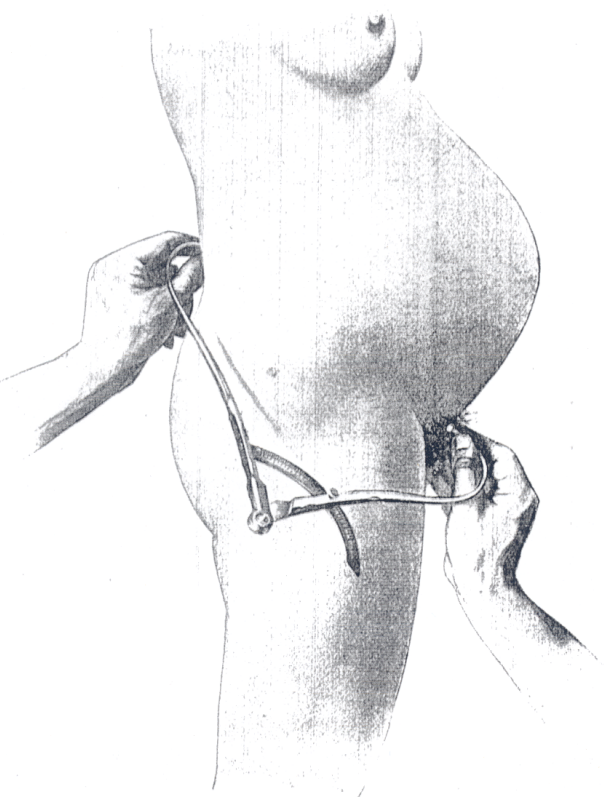

O pelvímetro foi um dos instrumentos criados pelos obstetras para obter as medidas da pélvis feminina com a finalidade de reconhecer viciações que pudessem comprometer o bom andamento do parto.

Fonte: $\quad$ Bumm, 1914. 
Tomando duas dessas imagens, uma da segunda metade do século XIX, outra do início do século XX, tem-se a mesma representação da relação de objeto estabelecida entre o médico-observador e o corpo examinado. Na Figura 6 tem-se a imagem da palpação abdominal para conhecer a posição do feto e na Figura 7 o exame pelvimétrico com o compasso de Baudelocque. Mais do que ensinar os exames, as imagens ensinam a ver o corpo como um objeto analisável, mensurável e passível de manipulações que só podem ser realizadas por quem o conhece. Ambas mostram quem é o objeto e quem é o sujeito do conhecimento. O objeto é passivo e ocupa a maior parte da imagem, sendo o centro da representação. O sujeito é ativo e só aparece no importante detalhe das 'mãos exploradoras'. ${ }^{48}$

Imagens como essas são representações do que Foucault (1986) chamou de corpo dócil, isto é, o corpo que pode ser submetido, utilizado, transformado e aperfeiçoado. Não podemos esquecer que essas imagens são representações de exames realizados em mulheres vivas - as pacientes uma categoria bem de acordo com o processo de objetivação. Tal observação é importante porque expõe a relação de força da representação: não é uma convenção que organiza a produção das imagens, mas o simples fato de que somente o médico podia observar, medir e representar o corpo feminino.

É por esse motivo que o número de publicações para uso didático aumenta consideravelmente na segunda metade do século XIX. O saber divulgado nos tratados de obstetrícia resultava das observações cada vez mais freqüentes e numerosas realizadas pelos médicos não só entre suas clientes particulares, mas em mulheres que procuravam atendimento nos hospitais, estes 'aparelhos de examinar', segundo expressão de Foucault. O resultado do incremento de observações pode ser constatado pela transformação dos livros de obstetrícia, verdadeiros guias do olhar médico. Cada assunto passou a ser detalhadamente representado por desenhos muito realistas ou, mais para o final do século, pelas fotografias. Nada escapa da rede visual que se arma sobre os corpos, a começar pelas superfícies, adentrando pelos tecidos, até a exposição da individualidade de cada corpo examinado, locus das patologias identificadas pelos médicos. Antes dos tratados médicos de obstetrícia, os corpos femininos nunca haviam sido expostos com tal realismo, nem mesmo na pintura. A mulher deixava de ser uma abstração ou um mistério ao ter seu corpo revelado pela Ciência, o que para os médicos significava o mesmo que conhecer sua totalidade.

Da mesma forma que o corpo grávido se prestava ao mapeamento, o momento do parto foi submetido ao exame minucioso dos médicos. ${ }^{49}$ Como 
ciência dos partos, o estudo do seu mecanismo foi de fundamental importância para a obstetrícia. O parto deixava de ser um acontecimento inesperado e misterioso para tornar-se um fenômeno singular, dividido em unidades de tempo e sujeito à quantificação. Vários estudos foram feitos sobre as posições fetais e sua relação com o corpo materno, o que exigiu tempo e determinação dos médicos para reconhecer todas as variações que podiam ocorrer.

A história da medicina refere-se aos obstetras da metade do século XIX como verdadeiros homens da Ciência, dedicados ao entendimento de fenômenos que exigiam habilidade, dedicação à pesquisa e compaixão pelas mulheres que sofriam no momento em que exerciam sua mais importante função.

Observando os tratados de obstetrícia produzidos na época, pode-se ver como o mecanismo do parto fisiológico ou patológico ocupa a maior parte dos estudos, que nunca eram inferiores a 700 páginas! É interessante observar que o número de mulheres que procuravam os médicos e hospitais para dar à luz começava a se ampliar principalmente numa época em que as parteiras ainda eram numerosas e a maioria dos partos ocorria em casa. No entanto, pode-se afirmar que a partir das décadas de 1820 e 1830 iniciouse um processo de transição do parto doméstico para o parto hospitalar em alguns países europeus, principalmente na França, na Inglaterra e na Alemanha, coincidindo com a grande produção do saber obstétrico. ${ }^{50}$

Como cientistas, os autores recorriam à casuística, este imenso arquivo de dados retirados da clínica, para sustentar empiricamente suas conclusões e afastar definitivamente a especialidade da especulação e das fantasias. O estudo dos partos passou a ser, portanto, um estudo científico dos diferentes movimentos do feto, ou, numa linguagem científica, um estudo da dinâmica destes movimentos.

Para agir, era necessário saber reconhecer cada momento do parto, das primeiras contrações até o nascimento da criança. Este intervalo de tempo, que podia ser bastante longo, foi minuciosamente estudado. O corpo da parturiente devia ser manipulado pelas mãos do médico para que fossem conhecidas as posições, o que exigia da mulher adotar certas posições e permanecer imóvel, mas nem sempre isso ocorria, pois muitas mulheres não aceitavam o toque vaginal e preferiam movimentar-se quando sentiam as contrações. Alguns médicos até aceitavam estes comportamentos, principalmente entre a clientela atendida em casa, mas a tendência foi convencer a parturiente que quanto mais ela colaborasse com o médico, deixando-se examinar, melhor seria o atendimento e mais seguros os resultados. ${ }^{51}$ 
Tomadas as medidas pélvicas, o próximo passo era conhecer a apresentação do feto, isto é, a parte do corpo que se apresentaria para sair do corpo materno. A maior parte das apresentações era pela cabeça, mas outras partes podiam se apresentar, o que significava um parto complicado, senão mortal, caso a mulher não tivesse ajuda, principalmente nas apresentações transversais, quando o feto vinha pela espádua.

Os obstetras dedicaram-se ao diagnóstico das apresentações e às técnicas para corrigi-las, fosse por meio das versões manuais, fosse com o uso de instrumentos ou pela cirurgia, embora este último recurso só fosse praticado em mulheres mortas até a década de 1870, quando novas técnicas cirúrgicas foram desenvolvidas evitando a morte da mulher por hemorragias. ${ }^{52}$

O conhecimento do mecanismo do parto teve grande impacto na extensão do controle médico sobre o corpo feminino. A obstetrícia tornarase um estudo preciso, quase matemático, ao transformar o corpo materno num espaço analisável, mensurável e passível de intervenção.

Figura 8 - Descida acima da pélvis e apresentação alta pelo ombro

A geometrização do corpo feminino como resultado do aprimoramento das técnicas do exame obstétrico.

Fonte: Fabre, 1910. Paris.

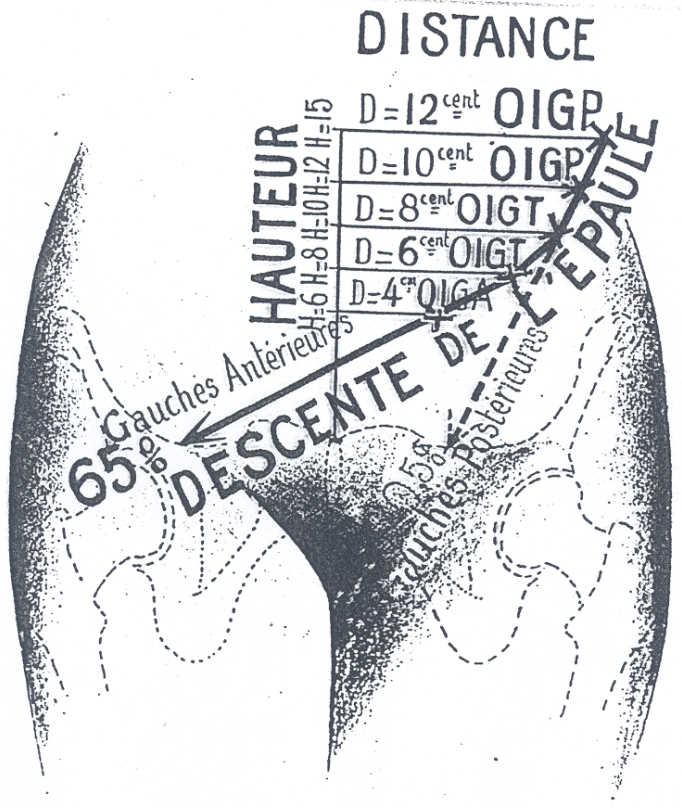


Observando a Figura 8, pode-se ver a pélvis feminina atravessada por medidas e vetores, integrando numa só imagem todo um conjunto de saberes produzidos durante o século XIX. Mais do que uma representação do corpo feminino, esta imagem é uma representação do olhar médico, um olhar de estrutura plurisensorial, como definiu Foucault (1980b). Os conhecimentos que estão integrados na imagem remetem para campos sensoriais diferentes, como o tato, a audição e a visão. Por trás de cada medida e sigla, há uma articulação de conhecimentos obtidos pela auscultação, pelo toque vaginal, pela palpação abdominal e pela anatomia da bacia, que é invisível, mas torna-se visível pela projeção dos conhecimentos anatômicos na superfície do corpo, como se pode ver pelo desenho pontilhado.

O estudo científico do parto produziu esta representação geométrica do corpo da mulher, totalmente visível e cada vez mais sujeito a intervenções sobre as quais ela não tinha conhecimento nem controle. A linguagem também não lhe era acessível - as dores tornaram-se 'pródromos'; a moleira passou a ser chamada 'occiput'; coroar a cabeça - um dos tempos do parto - passou a ser 'engajamento' na linguagem obstétrica, e assim por diante.

A intervenção no parto tornou-se mais freqüente no século XIX como conseqüência dos estudos anatomoclínicos. O instrumental obstétrico diversificou-se muito, sendo criados vários tipos de fórceps, sondas, agulhas, tesouras, ganchos e cefalotribos (instrumentos usados para a embriotomia), o que só reforçou ainda mais o controle médico sobre a parturição.

Figura 9 - Modelos de fórceps

O arsenal cirúrgico é o símbolo do poder do médico obstetra. Em mãos habilidosas o fórceps foi um dos mais importantes instrumentos obstétricos desde sua criação no século XVII.

Fonte: Bumm, 1914. Paris.
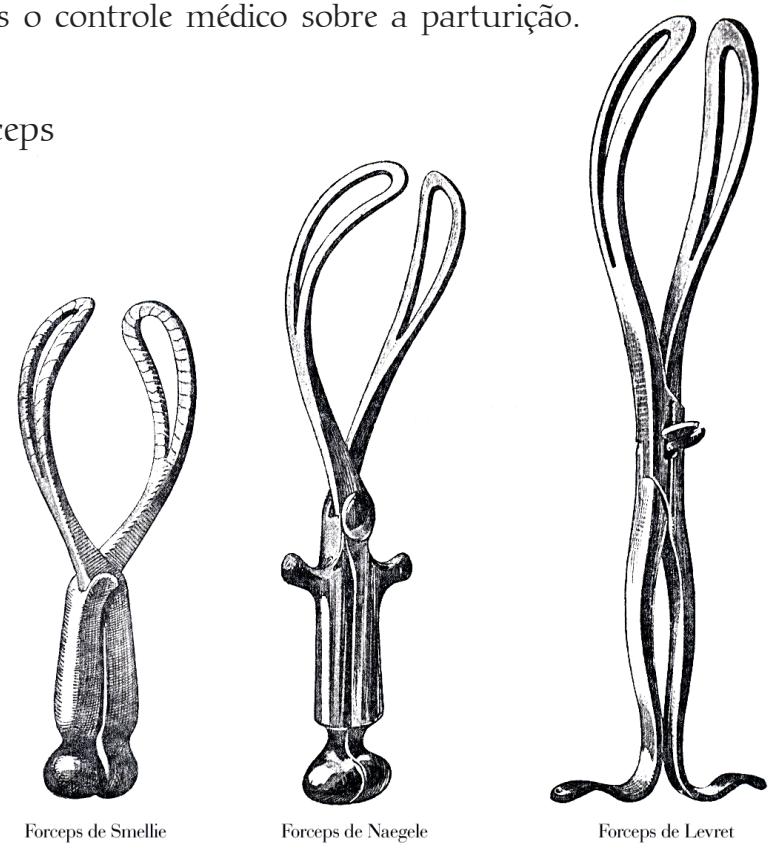
Os instrumentos obstétricos são reveladores de outra variante do biopoder: a crescente intervenção nos partos, nem sempre acompanhada de uma avaliação ponderada sobre a necessidade do uso dos fórceps, por exemplo, o instrumento-símbolo da ciência obstétrica. A Figura 9 mostra três tipos de fórceps: o de Smellie, de Naegele e de Levret. O primeiro é pequeno e só se presta para a extração simples da cabeça da criança, ou seja, revela como a obstetrícia inglesa e escocesa evitava excessos intervencionistas. Já o fórceps de Levret, o maior à direita, é o oposto. Tendo quase o dobro do tamanho do de Smellie, este instrumento era usado para vencer resistências maiores, isto é, quando a cabeça se encontrava presa mais acima, o que era adequado à prática mais intervencionista da escola obstétrica francesa. O fórceps de Naegele, obstetra alemão, apresentava dimensões intermediárias, que, segundo Ernest Bumm (1914), reunia as vantagens dos outros dois modelos.

Não se defende aqui uma atitude anticientífica, nem uma posição feminista nos moldes da década de 1970, que via na invenção e no aprimoramento do fórceps uma forma de usurpação masculina dos saberes femininos e a sujeição dos corpos a práticas punitivas. Não se pode negar que a aplicação correta do fórceps facilitou partos que poderiam acabar em tragédia. O enfoque aqui é sobre a natureza deste tipo de saber que teve, no mapeamento do corpo feminino e no desenvolvimento de tecnologias específicas, as condições essenciais para a formação de uma especialidade médica, bem como de uma autoridade para enunciar a verdade sobre seu objeto.

No final do século XIX, o parto hospitalar começou a se tornar uma prática cada vez mais aceita pelas mulheres, principalmente quando o sonho de Velpeau e de seus colegas tornou-se realidade com a criação das maternidades. Hospitais para mulheres e maternidades foram criados na Inglaterra, nos Estados Unidos, na França e na Alemanha durante a segunda metade do século XIX, atraindo um número maior de mulheres devido ao tipo de atendimento oferecido como o cuidado com a higiene, o uso da anestesia no parto e as operações obstétricas, que, quando bem realizadas, resolviam rapidamente partos complicados e muito dolorosos. ${ }^{53}$

Fechava-se, assim, um ciclo iniciado com os cirurgiões parteiros do século XVIII, munidos de alguns poucos instrumentos e vagos conhecimentos sobre o corpo feminino. O obstetra do final do século XIX reunia na mesma imagem o cientista, o homem culto e de princípios e o protetor da mulher. Se nos tratados de obstetrícia do início do século não 
há referências às relações entre o médico e a paciente, a não ser para descrever condutas que preservassem o pudor feminino, os textos produzidos no final do século XIX e início do XX são mais específicos a respeito do papel que os obstetras desempenhavam. Cresce a convicção de que o obstetra conhece a mulher, não só sua anatomia e fisiologia, mas sua alma, principalmente quando atormentada pelas dúvidas da gravidez e pelos receios quanto ao parto. Naegele (apud Magalhães, 1922a: 469) já antecipara o papel protetor do médico ao definir a obstetrícia como "a ciência de cuidar da mulher na parturição normal e socorrer a natureza quando se desviar deste caminho". ${ }^{54}$

A divulgação da imagem do médico protetor da mulher foi de grande importância para a legitimação do obstetra e para a aceitação das mulheres a dar à luz no hospital. Com a sofisticação dos exames de diagnóstico da gravidez no século $\mathrm{XX}$, a segurança dos procedimentos cirúrgicos e a mudança de ênfase para a saúde e o bem-estar do recém-nascido, os obstetras conseguiram ter controle não só do parto, mas do período gestacional, com o desenvolvimento do conceito de exame pré-natal.

Mas o significado da ciência obstétrica não se resume à conquista profissional dos médicos no atendimento aos partos e recém-nascidos. Os obstetras foram os primeiros a levar adiante o modelo biológico das diferenças sexuais estabelecido no século XVIII pelos anatomistas e fisiologistas. Seu foco de análise se fechou sobre as estruturas e os processos que eles consideravam ser a explicação para a natureza feminina e a justificação materialista dos papéis sociais das mulheres. Uma conseqüência importante desse processo de conhecimento foi a crescente intervenção com o uso de tecnologias médicas e farmacêuticas seguido pelo gerenciamento dos corpos femininos, cada vez mais passivos e alienados à medida que os saberes se especializaram e que a gravidez, o parto e o puerpério passaram a ser gerenciados pelo médico e, posteriormente, pela equipe hospitalar.

A ciência obstétrica constituiu-se tendo como objeto o corpo da mulher no exercício de suas funções reprodutivas, mas, no século XIX, uma outra especialidade médico-cirúrgica surgiu tendo o mesmo objeto, produzindo um saber específico sobre a mulher. Para isso, retomou o fio da especificidade sexual, procurando nos órgãos sexuais a resposta para sua definição e seus problemas, pois, como explicou o obstetra e ginecologista norte-americano Loomis (1941: 11), "doente ou com saúde a mulher é, afinal, a mulher". ${ }^{55}$ 
Herdeira de uma tradição intelectual e médica voltada para o estudo da alteridade feminina, a ginecologia se constituiu para estudar a natureza desta diferença e assim responder a uma velha questão que não cessava de ser colocada: o que é a mulher?

\section{Notas}

1 O quadro A Esperança II, de 1908, é muito diferente. A mulher está coberta com uma espécie de manto colorido, tendo apenas os seios nus. Seu rosto expressa tranqüilidade e está voltado para o próprio ventre, no recolhimento sereno da espera.

2 Sobre a reorganização das maternidades na Europa, especialmente na França do século XIX, ver Thebaud (1986).

3 Sobre o papel cultural das parteiras, ver Brack (1982).

4 Até meados do século XIX os médicos que exerciam esta especialidade eram chamados de médicos-parteiros ou sage-femmes en culottes (parteiras de calças), como eram conhecidos os cirurgiões franceses que faziam partos. Esta expressão é indicativa de como o parto era um assunto de mulheres para o qual nem a língua francesa tinha um substantivo masculino. A distinção entre a obstetrícia e a prática das parteiras só vai ocorrer a partir da segunda metade do século XIX. Ver Poovey (1987).

5 Os livros de história da medicina geralmente eram divididos por séculos, apresentando os médicos que mais se destacaram e suas contribuições para o desenvolvimento da medicina. Também era comum um capítulo histórico nos livros de obstetrícia do século XIX, apresentando breves comentários sobre as parteiras profissionais. Ver Renouard (1846) e Diepgen (1932).

6 A estrutura tripartite da medicina era regulamentada através das associações dos físicos, dos cirurgiões e dos boticários, mas na prática muitos cirurgiões e boticários atuavam como médicos, atendendo pessoas que não podiam arcar como os valores das consultas dos físicos, a elite formada pelas tradicionais universidades européias. Sobre o assunto, ver Moscucci (1993).

7 Essa é a análise de Laget (1977) e Shorter (1984). Se observarmos alguns frontispícios dos manuais de parto publicados no século XVI, veremos cenas em que as parteiras aparecem junto aos corpos mutilados de recém-nascidos ou então representações do parto como um evento coletivo, onde estavam várias pessoas, incluindo homens e crianças, além de animais. Ver também Speert (1973).

8 Ambroise Paré foi um dos primeiros cirurgiões parteiros do século XVI na França, reintroduzindo a versão podálica praticada pela medicina antiga e caída no esquecimento. Juntos, estes cirurgiões são considerados os 'pais' da obstetrícia moderna. Jacques Guilhemeau viveu na França no século XVI e publicou De la Grossesse et Accouchment des Femmes; François Mauriceau foi o grande nome da cirurgia e da obstetrícia do século XVII, junto com o holandês Hendrik van Deventer, publicando Traité des Maladies des Femmes Grosses et de Celles qui son Accouchées; William Smellie é considerado o grande nome da obstetrícia inglesa do século XVIII, publicando um Atlas anatômico ricamente ilustrado e seu Treatise on the Theory and Practice of Midwifery, em três volumes. Ver Speert (1973). 
9 Hunter, discípulo de Smellie, produziu um dos mais importantes e impressionantes trabalhos sobre o útero grávido: The Anatomy of the Human Gravid Uterus Exhibited in Figures. A obra foi escrita com extremo realismo, sendo Hunter o mais famoso parteiro de Londres na segunda metade do século XVIII. Sobre o assunto, ver Jordanova (1989). François Mauriceau atuou no Hôtel-Dieu fazendo milhares de observações e apresentando uma das primeiras estatísticas sobre a mortalidade materna, ver Laget (1977). Ver Gélis (1977: 927-957) e Laget (1977).

Sobre Justine, ver o artigo de Tatlock (1992). Cabe ressaltar o estilo do livro de Justine, construído na forma de um diálogo entre duas parteiras - a mestre e a aprendiz. Refiro-me especialmente aos trabalhos clássicos de Ehrenreich \& English (1973, 1979). A primeira escola de parteiras é a de Paris, de 1618, que funcionava no Hôtel-Dieu. No século XVIII, surgem várias escolas oficiais na Alemanha e na França e em 1770 as parteiras são admitidas na escola de cirurgia em Montpellier para assistir ao curso de partos. Ver Gélis (1977).

15 Os próprios médicos temiam por sua reputação, mas seu temor era que as mulheres se aproveitassem para tentar seduzi-los. Nos livros de ginecologia do século XIX e XX e nas teses médicas que abordam o exame ginecológico, há vários procedimentos e conselhos para que os médicos tomassem todas as precauções a fim de evitar o atentado ao pudor e as investidas das pacientes.

16 Sobre Hecquet e a reação moralista aos parteiros, ver Gélis (1977) e Laget (1977).

17 Sobre Nihell, ver Speert (1973) e Gélis (1977).

Gélis (1977: 956) comenta que o verbete 'parteiro' da Encyclopédie define a obstetrícia como uma atividade masculina associada ao uso do instrumental: "Armado do instrumento de Chamberlen, aperfeiçoado por Levret, na França, e por Smellie, na Inglaterra, a obstetrícia é uma ciência viril".

19 Sobre os quadros de temas médicos, ver Dottin-Orsini (1996).

20 Sobre a medicina clássica, ver Foucault (1980b).

21 Sobre o poder do Estado, ver Rosen (1983) e Foucault (1985).

2 Rosen (1983) explica que na França e na Alemanha os médicos envolveram-se diretamente com políticas públicas visando a conhecer os problemas sociais de saúde e propondo medidas profiláticas e terapêuticas, processo este conhecido como a constituição da medicina social.

23 Ver Donzelot (1986), especialmente o capítulo "A conservação das crianças".

24 Sobre as transformações afetivas nas relações entre mães e filhos e a constituição da família moderna, ver Ariès (1981), Badinter (1985) e Shorter (1985).

25 Sobre a literatura da conservação das crianças produzida por médicos, ver Donzelot (1986). Em língua portuguesa, também havia alguns títulos disponíveis desde meados do século XVIII, como se pode verificar no livro de Del Priore (1993).

26 Xavier Bichat, fundador da histologia, publicou Recherches sur la Vie et la Mort em 1800, dois anos antes de sua morte, sendo um dos primeiros investigadores das relações entre fisiologia e patologia. François Magendie foi um dos primeiros pesquisadores do sistema nervoso e professor de Claude Bernard. Este, por sua vez, dedicou-se inteiramente à pesquisa biológica, sendo considerado o fundador da fisiologia experimental, 
publicando, entre tantos trabalhos, Introduction à l'Etude de la Médicine Experimentale, em 1865, onde expõe seu método de pesquisa e defende o princípio da objetividade absoluta no trabalho científico. Claude Bernard era tido por seus contemporâneos como o exemplo de cientista, a quem só importava estabelecer a verdade dos fatos. Esta nova atitude ante os fenômenos naturais influenciou sobremaneira a cultura oitocentista, em especial a literatura, que encontrou nas ciências biológicas e na medicina seu modelo estético para representar a realidade. Sobre a fisiologia experimental, ver Canguilhem (1995). Sobre as relações entre a literatura e as ciências biológicas, ver Sussekind (1984).

27 Tomo como referência a análise desenvolvida por Foucault $(1980 b, 1986)$ a respeito da clínica e das técnicas de disciplina hospitalar.

${ }^{28}$ A falta de experiência dos alunos de medicina nos assuntos de obstetrícia e ginecologia foi motivo de várias queixas e reclamações dos professores e autores de livros de obstetrícia do século XIX. Como veremos, a situação era a mesma, senão pior, no Brasil, como relatou Dr. Fernando Magalhães, no seu trabalho de pesquisa histórica sobre a obstetrícia. Ver Magalhães (1922b).

29 Segundo Moscucci (1993), várias escolas privadas de obstetrícia surgiram nestes países na segunda metade do século XVIII, bem como a fundação de hospitais com enfermarias para atender às parturientes, o que facilitava a formação prática dos alunos e das parteiras. Algumas iniciativas nesse sentido foram tomadas no continente europeu, como na Dinamarca e em várias cidades alemãs a partir de 1751 e nos hospitais franceses. Ver Foucault (1980b) e Bumm (1914).

30 Ver Moscucci (1993).

31 Ver Knibiehler (1976).

32 É interessante observar como as mulheres de elite estiveram envolvidas nas campanhas para a fundação de maternidades e hospitais para mulheres, apoiando os médicos na arrecadação de fundos para estes estabelecimentos. No Brasil, a criação de maternidades e até mesmo a implementação de políticas de saúde materno-infantis não podem ser entendidas sem a participação das senhoras da sociedade locais, cujo movimento filantrópico foi de fundamental importância para a divulgação da necessidade deste tipo de atendimento às mulheres pobres. Ver Martins (1986). Esta observação também pode ser encontrada em Badinter (1985).

33 Vários são os autores que reclamam desses impedimentos, entre eles Depaul (1876) e Velpeau (1835). A resistência das mulheres aos exames realizados na frente dos estudantes foi o motivo de conflitos e até mesmo de abandono das enfermarias, o que fomentou a crítica destes e outros autores aos costumes que procuravam defender a moral das mulheres.

34 Velpeau representa muito bem o novo médico do século XIX, combinando sua profissão com a pesquisa científica. Desde 1825 publicou trabalhos de patologia, cirurgia e fisiologia, dedicando-se, na década de 1830, à embriologia e à obstetrícia. Além de seu Tratado, publicou Embryologie ou ovologie Humaine, em 1833, e Des Convulsions chez les Femmmes Pendant la Grossesse, Pendant le Travail et Après L'Accouchement, em 1834.

35 Essa é uma expressão cunhada pelo autor. Velpeau explica que desde 1823, quando começou a lecionar, usava o termo obstetrícia, como faziam os cirurgiões ingleses, mas não achava esta palavra adequada, já que derivava da palavra latina obstetrice, que significa parteira. Velpeau preferia usar a palavra de origem grega tocologia, como fez 
no título do livro, que significa estudo dos partos. Embora as palavras obstetrícia e obstetra se tenham tornado correntes, percebe-se a intenção de Velpeau em querer dissociar a especialidade dos partos praticada pelos médicos daquela praticada pelas parteiras, reforçando o caráter racional e científico da tocologia. Atualmente, os médicos se especializam em obstetrícia, mas alguns departamentos das escolas de medicina incorporaram a definição científica defendida por Velpeau ao denominarem-se departamentos de tocoginecologia, unindo a ciência dos partos à ciência da mulher.

36 Segundo o obstetra francês Charles Mauriac, na Inglaterra, cuja tradição obstétrica era notável, o establishment médico foi recalcitrante em relação à obstetrícia e à ginecologia. Comenta que em pleno século XIX o Colégio dos Médicos de Londres havia declarado publicamente que a arte dos partos era uma ocupação indigna para o homem educado. Ver prefácio do livro de West (1870).

37 Devido ao grande número de publicações deste gênero, foram selecionadas as obras que eram recorrentemente citadas pelos estudantes de medicina brasileiros e que faziam parte do acervo das bibliotecas das faculdades de medicina do Rio de Janeiro e Salvador; outro critério adotado foi a intercitação.

38 Jean Bologne (1990) comenta que a vergonha feminina em mostrar o corpo para o médico era ainda uma realidade difícil de contornar no século XIX, mas não eram só as mulheres que defendiam seus pudores, muitos médicos sentiam-se constrangidos ao ter de examinar as mulheres, o que levou alguns deles a defender a necessidade de mulheres médicas. Algumas ilustrações de exames médicos do século XIX abordam a questão dos pudores, pois mostram exames realizados em mulheres vestidas e sem contato visual com o médico.

39 No tratado de partos de Chailly-Honoré (1861), usado como obra didática por deliberação oficial do governo francês na década de 1840, há referências quanto à conduta que o obstetra deveria ter ao realizar os exames nas grávidas. O autor explica que freqüentemente as mulheres resistiam aos exames, especialmente ao toque ginecológico, mas que o médico deveria fazê-las perceber que tal procedimento era para conhecer o estado das coisas, a fim de assegurar o bem-estar da mãe e do filho.

40 Velpeau (1835) referiu-se à palpação abdominal no seu livro, e vários artigos médicos publicados na primeira metade do século divulgaram os benefícios deste procedimento. Ver em Lima (1909).

${ }^{41}$ A associação entre revelação do corpo feminino e conhecimento científico foi tema de diversas representações imagéticas na cultura oitocentista, conforme análise de Jordanova (1989).

42 É interessante observar as correspondências entre os saberes presentes nesta imagem. O responsável pela reprodução dos desenhos foi Ambroise Tardieu, um dos mais importantes legistas franceses do século XIX, professor da Faculdade de Medicina de Paris na mesma época em que Velpeau lecionou. Tardieu interessou-se também pela obstetrícia, tendo em vista suas interfaces com a medicina legal, escrevendo alguns trabalhos sobre o aborto e o infanticídio. Sobre a medicina legal, ver Darmon (1991).

43 Segundo Barthes (1984), os pormenores produzem um efeito de realidade e seu papel nas narrativas realistas é autenticar o real, como se dissessem 'somos o real'. O mesmo raciocínio é válido para as imagens, nas quais os pormenores criam a ilusão de realidade. Ver também Jordanova (1989). 
44 Darmon (1991) comenta que durante o século XIX os craniologistas e, posteriormente, os criminalistas, criaram diversos instrumentos de medida de diferentes partes do corpo, constituindo um conjunto fantástico de dados quantitativos que deveriam, supostamente, mostrar os desvios dos padrões da normalidade racial, sexual e social.

45 Burdach foi um dos fisiologistas envolvidos nas pesquisas sobre as diferenças sexuais na química do corpo, conforme analisado no Capítulo 1.

46 Levret foi também um inventor de instrumentos obstétricos, como o fórceps, que foi aperfeiçoado por ele. Ver Speert (1973).

47 Considerando as três partes da bacia (superior, escavação e inferior), os médicos chegaram a um total de 17 tipos diferentes de diâmetros pélvicos, cujas medidas serviram para estabelecer padrões de normalidade e classificações de tipos de pélvis. Ver Paraíso (1910).

48 Expressões como 'mãos exploradoras' ou 'dedos exploradores' eram muito usadas nas teses de obstetrícia e ginecologia, conforme pude constatar.

49 Depaul (1876), obstetra francês e professor da clínica de partos da Faculdade de Medicina de Paris, seguidor de um dos mais importantes obstetras franceses da primeira metade do século, que foi Dubois, explicou que das observações que fez durante 30 anos atendendo parturientes, ensinou seus alunos e reuniu num pequeno museu 'exemplares' patológicos e fisiológicos que favoreceriam os estudos, serviam como material didático e estavam à disposição de seus alunos como material de pesquisa para suas teses ou outros trabalhos acadêmicos. Ao analisar o significado dos hospitais e clínicas para mulheres criados no século XIX, Ornella Moscucci (1993) diz que estes espaços eram verdadeiras galerias de tipos femininos e museus vivos de patologia que forneceram oportunidades únicas para os médicos conhecerem as mulheres e suas doenças.

50 Tal afirmação é resultado da observação de algumas estatísticas divulgadas pelos autores de tratados obstétricos. Velpeau (1835) reproduz um quadro de atendimentos obstétricos da Maternidade de Bourg, cidade próxima a Lyon, onde 1.399 mulheres foram atendidas entre 1822 e 1828. James Simpson, famoso obstetra escocês, relatou que entre 1847 e 1850 havia atendido 1.519 partos, e Michaelis, obstetra alemão, desenvolveu seus estudos anatômicos da pélvis feminina observando 1.000 pacientes. Ver Também Simpson (1874) e Speert (1973).

51 Alguns autores referem-se ao comportamento das parturientes como um dos problemas que o obstetra teria de saber contornar, bem como as opiniões e exigências dos familiares, que foram sendo afastados da cena do parto conforme o médico foi impondo sua autoridade, ficando no máximo com o auxílio de uma parteira ou de alguma pessoa de confiança da parturiente. Sobre o rigor do método de observação do mecanismo do parto, Chantreuil, tradutor do livro de Simpson na França, comenta que Naegelé, obstetra alemão, cujo tratado foi traduzido para várias línguas, ficou oito horas consecutivas observando os movimentos da cabeça do feto num parto, sendo considerado o exemplo de investigador incansável e de espírito metódico. Ver Chailly-Honoré (1861) e Simpson (1874).

52 A cesariana só foi praticada com sucesso depois de 1878, com o método de Porro, cirurgião italiano que desenvolveu a técnica cirúrgica da amputação do útero para evitar a hemorragia. Ver Thorwald (s.d). 
53 A partir de 1860, os médicos começaram a preocupar-se com a questão da higiene hospitalar, especialmente nas maternidades, onde os princípios da anti-sepsia e isolamento de mulheres doentes foram colocados em prática graças aos esforços de Stephane Tarnier, um dos mais importantes obstetras da época que se dedicou ao estudo da febre puerperal. O uso do clorofórmio nos partos foi, sem dúvida, um atrativo para as mulheres. Ver Moscucci (1993) e Shorter (1984).

54 Palestra proferida aos alunos do curso de clínica obstétrica em 1916.

55 Loomis exerceu a medicina no início do século XX. 


\section{A ciêncía da Mulher}

Em nossos dias talvez não haja uma imagem tão respeitada como a do cirurgião. Com a crescente especialização da medicina ao longo do século $\mathrm{XX}$ e o desenvolvimento de um incrível aparato tecnológico que desvelou os espaços mais recônditos do corpo humano, a cirurgia tornou-se uma prática extremamente especializada e valorizada no meio acadêmico e no exercício da profissão. ${ }^{1}$ No entanto, quando os cirurgiões ainda ensaiavam suas incertas e perigosas ações nos corpos de pacientes aterrorizados com a dor, as mutilações e, não menos freqüente, a morte, pairava uma sombra de desconfiança sobre a capacidade destes profissionais e mesmo de suas intenções. Desde meados do século XVIII, quando, na Inglaterra, o ensino de anatomia, por parte dos cirurgiões, ampliou-se consideravelmente em diferentes instituições hospitalares e de ensino, cresceu a demanda por corpos e, assim sendo, a desconfiança das pessoas, como bem explicou Linebaugh (1975) ao tratar dos motins contra o uso dos corpos dos condenados à morte para a dissecação.

No século XIX, os cirurgiões começaram a se tornar mais respeitados aos olhos da clientela, particularmente na segunda metade do século, com a introdução dos anestésicos e os cuidados com a higiene hospitalar, além do aperfeiçoamento da formação dos médicos e cirurgiões com os estudos experimentais de anatomofisiologia produzidos nos laboratórios com o uso de cobaias animais. ${ }^{2} \mathrm{Na}$ história da medicina, entre os mais eminentes cirurgiões de meados do século XIX figuram aqueles que se dedicaram à cirurgia ginecológica. Moscucci (1993) relata como as cirurgias ginecológicas e mesmo os exames realizados com o espéculo causaram reações extremas, variando da confiança progressista às acusações de 
imoralidade e uso dos corpos femininos em experiências, como os médicos e cientistas faziam em animais.

O debate em torno de novas técnicas cirúrgicas dividia também os médicos. Embora não se possa falar de uma reação contra a cirurgia especificamente, nem todos os médicos recorriam à cirurgia ginecológica, preferindo as terapêuticas mais conservadoras. Entre os cirurgiões, a preocupação era com os excessos e com médicos despreparados para fazer diagnósticos de doenças ginecológicas que demandavam tratamento cirúrgico.

Em um de seus cursos sobre doenças de mulheres, o Dr. Charles West (1870), médico inglês que atendia no antigo hospital londrino SaintBarthélemy, alertava seus alunos para a degradação de alguns cirurgiões que se especializaram em 'curar a masturbação'. Relata, então, a história de uma senhora de 53 anos, sua conhecida, sofria de uma fístula rectovaginal que muitos sofrimentos lhe causava, impedindo-a de ter uma vida normal. Procurou um cirurgião, e este, sem dizer nenhuma palavra à mulher, nem ao seu marido, extirpou-lhe o clitóris. Passado o período de convalescença, a mulher descobriu que, além da cirurgia que fora procurar para resolver sua incômoda situação, outra havia sido feita. Ao indagar o cirurgião para saber por que procedera daquela forma, ouviu do mesmo que tomara tal decisão porque supôs que a mulher era dada à prática de um 'vício' do qual ela não conhecia nem o nome, nem a natureza.

Essa história foi publicada em 1856 depois de dez anos de magistério e clínica; nela, West, como cirurgião que era, critica veementemente os excessos de alguns de seus pares, especialmente no que se referia à 'cura' da masturbação, colocando em dúvida as idéias correntes a respeito dos males físicos e psíquicos que o 'vício' podia causar às mulheres e aos homens.

Na época em que West escreveu seu livro, a ginecologia começava a se tornar uma especialidade cirúrgica. Mesmo sendo uma prática médica bastante antiga, só recebeu o estatuto de especialidade na segunda metade do século XIX, quando foi definida como a 'ciência da mulher', baseada na observação, na técnica cirúrgica e na constatação da radical diferença sexual da mesma. Até meados do século XIX as mulheres não formavam uma categoria diferenciada de clientes. Quando grávidas ou por ocasião do parto, a maioria procurava os serviços das parteiras ou de um médico parteiro. Geralmente, era o médico da família ou aquele que havia realizado o parto que tratava dos outros problemas das mulheres, como as doenças ginecológicas. Assim, até a época em que West publicou suas lições 
predominava uma prática um tanto quanto indefinida em relação às mulheres, mesmo porque até então não havia ainda o que hoje conhecemos como especialidades, a não ser a obstetrícia e a medicina legal e mesmo assim só em algumas faculdades européias.

No entanto, a produção do discurso médico sobre a mulher era bastante significativa desde a segunda metade do século XVIII, conforme analisado anteriormente. Evidentemente tratava-se de um conjunto de textos de caráter prescritivo fundado em princípios morais. Com a ressignificação política da família, os corpos infantis e femininos passaram a ser o alvo das regulações e dos controles, o que levou muitos médicos a se interessarem pelas peculiaridades das doenças das mulheres. ${ }^{3}$

A aproximação entre médicos e mulheres foi de grande importância para definição de um novo campo da prática médica no século XIX voltado à especificidade da natureza feminina, uma noção muito em voga a partir de então, que parecia ter, para os médicos, uma complexidade que extrapolava sua função reprodutiva. Definia-se o perfil de uma categoria específica de paciente, cujas particularidades demandavam as atenções e os serviços de um profissional que visse a mulher como um todo e não apenas como grávida e parturiente. Os anatomistas e fisiologistas já haviam fornecido provas da radical diferença física entre os sexos, e esta diferença adquiria um significado especial para as mulheres, cujo sexo era percebido como fonte de problemas, de inquietações e, portanto, passível de regulações.

Portanto, a história que o Dr. West contou aos seus alunos, além de ser um alerta quanto aos limites éticos da profissão, é também a narrativa de uma especialidade cada vez mais voltada para o tratamento cirúrgico dos órgãos sexuais femininos. Tal orientação da especialidade é o corolário de uma longa tradição intelectual e médica a respeito da sexualidade feminina, construída a partir do desejo de conhecer e controlar sua diferença.

\section{A Caixa de Pandora: a sexualidade feminina no discurso médico}

É interessante observar como na história das idéias e dos saberes algumas noções ou definições parecem intocáveis, melhor dizendo, têm uma vitalidade histórica contínua, apesar das rupturas epistemológicas que ocorreram no campo das ciências naturais e humanas, especialmente neste nosso século. Ainda hoje prevalece a representação corpórea e 
sexualizada da mulher em oposição à representação cerebral e racionalizada do homem. Apesar de esta dicotomia não ser restrita aos espaços de produção do conhecimento científico, as dicotomias de gênero, fundadas na diferença sexual, têm uma história que se enraíza no processo de constituição dos saberes médico e científico sobre estas diferenças.

Na verdade, acostumamo-nos com a representação corpórea e sexualizada da mulher através do sutil mecanismo ideológico da naturalização. Evidentemente não se trata de negar as diferenças sexuais, nem a corporalidade, mas sim de questionar a naturalização destas representações e explicitar seu conteúdo ideológico. Expressões como "a mulher é o seu corpo" ou "tudo no corpo da mulher é sexualizado" não são (ou dificilmente seriam) traduzíveis para a definição da masculinidade, não porque sejam representações de fatos naturais, mas porque são representações de uma construção humana e histórica de relações sociais fundadas sobre a oposição e a assimetria entre os dois sexos biológicos. ${ }^{4}$

As frases anteriores e o seu significado mais amplo para a identidade feminina são a expressão do que Keller (1985) chamou de sistema sexogênero e que Lauretis (1994: 211) assim definiu:

As concepções culturais de masculino e feminino como duas categorias complementares, mas que se excluem naturalmente, nas quais todos os seres humanos são classificados, formam, dentro de cada cultura, um sistema de gênero, um sistema simbólico ou um sistema de significações que relacionam o sexo a conteúdos culturais de acordo com valores e hierarquias sociais.

Interessa-nos particularmente entender como o gênero foi equacionado com um dado biológico - o sexo - e como este passou a ter uma relação metonímica com a mulher.

A 'descoberta' do sexo como um fenômeno natural e sua circunscrição ao domínio do saber científico e médico foram de grande importância para a consolidação do sistema sexo-gênero, porque enraizaram na Natureza as hierarquias e as desigualdades que dividiam a espécie humana em duas partes opostas, dois sexos cujos corpos eram radicalmente marcados pela diferença. No entanto, a equação sexo-gênero não foi utilizada para definir o homem da mesma forma como o foi para a mulher. A palavra homem nunca teve a mesma conotação sexual, nem mesmo quando anatomistas e fisiologistas do século XVIII iniciaram suas investigações sobre as distinções físicas entre os dois sexos, como vimos. Muito pelo contrário, quase sempre, 
mesmo em nossos dias, o vocábulo homem significa humanidade, é sinônimo da espécie humana. Podemos dizer que no binômio sexo-gênero o homem foi dessexualizado, tornando-se um ideal, uma representação dos valores distintivos da espécie humana muito valorizada pelo ideário iluminista, como a razão, a inteligência e a moral. A antiga visão dualista que opunha corpo e mente ou carne e espírito foi reatualizada nos discursos médico e filosófico do século XVIII, articulando sexo e corpo à feminilidade em oposição à articulação razão e mente, predicativos da masculinidade.

Tais associações e disjunções não se teriam estruturado num sistema sexo-gênero sem a contribuição e a chancela da ciência e da medicina. Ambas reconheciam as diferenças sexuais, mas atribuíram à mulher a predominância do sexo, não só na materialidade física do corpo, mas como um verdadeiro estigma que marcava sua total existência. Era como se a mulher fosse um ser prisioneiro de seu próprio corpo; portanto, limitada em comparação ao seu companheiro de espécie, para quem o sexo e seus ditames só eram determinantes em alguns momentos de sua vida, especialmente quando era premente a reprodução, como acreditavam Rousseau e os médicos contemporâneos ao filósofo. Entende-se, assim, porque a palavra sexo foi, pelo menos até o final do século XIX, usada como sinônimo de mulher, uma associação que trouxe muitas conseqüências para as mulheres do passado e do presente. ${ }^{5}$

Uma dessas conseqüências é a imagem construída pelos médicos a respeito da organização do corpo feminino. Ao longo do século XIX, obstetras, ginecologistas e médicos legistas usaram os resultados de experiências anatomofisiológicas para fundamentar suas teorias sobre a organização nervosa do corpo feminino, em sistema de rede, ligando ovários e útero através de gânglios e nervos ao eixo cérebro-espinhal. ${ }^{6} \mathrm{O}$ problema reside nas interpretações ideológicas que foram dadas a tal organização. Os médicos estabeleceram que na mulher este sistema era instável, marcado pelo desequilíbrio e que, portanto, qualquer excitação periférica - sempre de origem sexual - poderia perturbar o frágil equilíbrio do sistema e causar problemas psíquicos que variavam de uma simples dor de cabeça chegando a estados melancólicos, manifestações histéricas e delírios que podiam levar as mulheres a cometerem atos contrários à sua vontade, como o infanticídio e o suicídio.

Essa imagem nervosa e instável do corpo feminino contribuiu para restringir a existência das mulheres a limites impostos pela lei biológica 
imanente a esta organização. Um ser predisposto mensalmente a doenças e perturbações mentais não podia se aventurar, como os homens, a querer exercer atividades físicas e intelectuais para as quais não tinha corpo nem cérebro adequados e preparados para receber os estímulos que tais atividades proporcionavam. Assim, os médicos juntaram-se aos ideólogos da domesticidade ao mesmo tempo em que chamaram para si a responsabilidade em prevenir e curar as manifestações mórbidas, mais variadas, da instável natureza feminina. ${ }^{7}$

A ginecologia se constituiu no século XIX tendo como referência essa imagem da mulher submetida ao império de seus órgãos genitais. Os médicos que advogavam a necessidade da especialidade não tinham uma visão limitada do que deveria ser este novo campo da medicina, isto é, uma especialidade em doenças de mulheres, mas ambicionavam construir um campo de conhecimentos totalizantes a respeito da feminilidade, como bem definiu Dr. Barnes (apud Moscucci, 1993), famoso obstetra e ginecologista inglês do século XIX, ao dizer que mais do que tratar das patologias femininas os ginecologistas deviam conhecer a natureza feminina, estudando cuidadosamente suas características morais e intelectuais. Barnes propunha os fundamentos de uma ciência e não simplesmente de uma patologia e uma terapêutica exclusiva às mulheres, ao defender um conhecimento que abrangesse a interação entre o corpo sexuado da mulher e seu comportamento. Se para os médicos renascentistas e iluministas o corpo da mulher e a natureza feminina estavam envoltos sob os véus do mistério, para os médicos do século XIX o olhar desimpedido sobre os órgãos sexuais femininos revelaria sua essência, sua verdade.

Tomados em conjunto, o que se observa é que os textos produzidos pelos médicos durante o século XIX a respeito da definição sexual da mulher revelam as ansiedades dos médicos diante das incertezas geradas pelo mais completo desconhecimento em relação à sexualidade feminina. Se, de um lado a aproximação entre médicos e mulheres favorecia as condições necessárias para o conhecimento da natureza da mulher; de outro, aumentava o mal-estar masculino em relação à sexualidade feminina, quase sempre equacionada ao excesso ou à ausência. ${ }^{8}$

Ao estudar as mulheres, os médicos criaram um paradoxo que marcou a produção do conhecimento sobre a sexualidade feminina até o século XX. Embora definissem a mulher pela sexualidade, muitos médicos defendiam a tese de que a normalidade era a ausência do desejo e a incapacidade de 
alcançar o prazer sexual. A mulher normal seria, portanto, anestesiada para o exercício de sua sexualidade, estando canalizada para a reprodução. Lombroso divulgou estas idéias ao dizer que "o amor feminino não é mais do que um aspecto secundário da maternidade e todos os sentimentos de afeto que ligam a mulher ao homem não nascem do impulso sexual, mas são instintos de sujeição e de devoção adquiridos por adaptação" (Lombroso \& Ferrero, 1923: 92). Numa linguagem pastoral, Stall (1907), autor de vários livros de orientação sexual que alcançaram vendagens superiores a um milhão de cópias nos Estados Unidos e na Europa, explica que a indiferença ou a aversão das esposas às demandas sexuais dos maridos era um sinal da sabedoria divina que não dotou a mulher da mesma paixão sexual que os homens, pois, se assim o fosse, estes seriam esgotados em seu poder reprodutivo, colocando em risco a continuidade da raça.

O paradoxo da sexualidade feminina tal como foi formulado no século XIX deve-se ao fato de que os médicos tomaram como modelo a sexualidade masculina genitalizada, mais especificamente associaram o desejo e o prazer sexual à experiência masculina da ereção e da ejaculação. Como as mulheres não apresentavam nenhum destes fenômenos, a conclusão mais plausível era o papel passivo da mulher no exercício normal da sexualidade. Na teoria, esta explicação aplacava as ansiedades, mas a diversidade das experiências sexuais femininas e as queixas que as mulheres acabavam deixando escapar para seus médicos não deixavam dúvidas de que algo não ia bem com as mulheres que pareciam inadequadas ao modelo da passividade sexual. ${ }^{9}$

O debate em torno da sexualidade feminina na segunda metade do século XIX se deu no terreno da patologia. Quanto mais os médicos pesquisavam os comportamentos femininos, mais se fortalecia a imagem hiperssexualizada da mulher - um processo que Foucault (1980a) denominou de histerização do corpo feminino. Esta formulação é bastante adequada para se pensar os dispositivos por meio dos quais a sexualidade feminina tornou-se um problema e o corpo da mulher um objeto que requeria intervenção médica, apesar da histeria ter sido associada com o mau funcionamento dos órgãos reprodutivos desde a época clássica da medicina grega.

A diferença apontada por Foucault a respeito do processo que ocorre no século XIX é que toda e qualquer doença feminina foi interpretada pelos médicos como tendo etiologia sexual, ou seja, a definição da feminilidade estava intrinsecamente associada à patologia e requeria intervenção médica. 
Wood (1973) comenta como as mulheres norte-americanas de camadas médias acreditavam que viviam doentes porque eram mulheres, ou seja, as queixas e os sintomas que descreviam eram sempre associados ao mau funcionamento dos seus órgãos sexuais.

Mas a sexualidade feminina não foi abordada unicamente pelo conjunto múltiplo de sintomas histéricos. Na segunda metade do século XIX, os médicos voltaram-se para a questão do desejo sexual feminino, aqui relacionado à noção de desvio, não só patológico, mas moral. Os médicos incluíam as mulheres no conjunto dos pervertidos, homens libertinos e crianças que se dedicavam à busca do prazer sexual pela masturbação. A verdadeira guerra que se travou contra o onanismo no século XIX foi originalmente contra os homens e integrou o processo de pedagogização do sexo infantil, de acordo com Foucault (1980a). Mas, a partir do momento em que a sexualidade feminina passou a ser problematizada pelos médicos, alguns se dedicaram a esquadrinhar esta prática entre as mulheres, algo que até então não era muito difundido no âmbito da medicina.

A preocupação com o que faziam as mulheres quando estavam sozinhas levou muitos médicos a escreverem sobre a masturbação, entre eles o Dr. Pouillet, autor de um tratado sobre o assunto, que alcançara a sétima edição em 1897. Da mesma forma que Parent-Duchatelet tornouse uma autoridade médica a respeito da prostituição, o livro de Pouillet foi, para os médicos e estudantes de medicina do final do século XIX, uma referência obrigatória sobre a masturbação feminina, principalmente devido à extensão e aos detalhes de sua obra. ${ }^{10}$

Como o exercício da sexualidade feminina só era admissível na companhia do homem e preferencialmente no casamento, a idéia de uma sexualidade sem limites e sem regras era insuportável para a moralidade da época, reforçada pelos argumentos médicos. Como parte da cruzada moralista e higienizadora, médicos como Pouillet procuraram alertar outros médicos, os pais e educadores para os males terríveis que julgavam ser desencadeados pela prática do 'vício solitário'.

É com esse objetivo que Pouillet (1897) justifica a ação médica num terreno que, até então, acreditava-se ser da moral, pois a masturbação ameaçava o corpo, a inteligência e a própria raça, o que exigia a intervenção médica. Nesta cruzada havia uma lacuna a preencher, segundo o autor, pois muito se falava a respeito da prática da masturbação entre os homens, mas quase nada se sabia sobre a 'paixão manual' entre as mulheres. Pouillet então 
escreveu seu livro com o objetivo de preencher esta lacuna e solucionar o problema, dizendo que, ao contrário do que se acreditava, a mulher era mais dedicada à manipulação devido à sensibilidade característica de seus órgãos genitais e à fragilidade de sua vontade, que a impedia de resistir às causas externas que levavam ao 'vício'.

Pouillet (1897) comenta que os médicos sabiam do problema, mas que ninguém havia tratado cientificamente do mesmo, talvez por uma "delicadeza mórbida e incompreensível da Medicina" (1987: 13). Cientificamente, então, o autor define seu objeto:

O onanismo entre as mulheres é um ato contra a natureza, feito com o auxílio de um órgão vivo, de um instrumento qualquer ou de movimentos especiais, parciais ou generalizados, com o objetivo de provocar o espasmo venéreo, que pode ser solitário ou executado com outras pessoas. (1897: 20)

A divisão dos capítulos acompanha a seqüência apontada no subtítulo deste livro: as formas, as causas, os sinais, as conseqüências e o tratamento. Ao tratar das formas, o autor segue a configuração anatômica dos órgãos genitais, concluindo que a depravação das masturbadoras podia chegar a tal ponto que inventavam manobras novas em partes do corpo, que, pela definição médica da sexualidade, não eram inteligíveis a não ser como expressão da 'engenhosidade mórbida' das 'infelizes delirantes' que se entregavam à busca incessante do prazer sexual. ${ }^{11}$

As causas são muito variáveis e numerosas, demandando um longo capítulo para discorrer sobre o assunto. Como um conhecedor dos estudos anatomofisiológicos, Pouillet enfatiza as causas físicas da masturbação, como pruridos, inflamações, doenças útero-ovarianas, extrema sensibilidade nervosa das mulheres, afecções encefálicas e loucura. Até o final do século XIX prevaleceu a tese de que a histeria e a ninfomania tinham uma causa física, fosse no útero, nos ovários, ou nas complexas redes nervosas que ligavam os órgãos sexuais a outros como o cérebro.

Mas havia ainda as causas sociais, intelectuais e morais. Este é o outro aspecto do desvio patológico da sexualidade feminina, segundo Pouillet. Ele condenava os exercícios físicos prolongados para as mulheres, como a dança, a equitação e o ciclismo. Seguindo uma tendência já consolidada pelo discurso de cunho moral, era contrário à leitura de romances, a que assistissem certas peças de teatro e à observação de pinturas e esculturas de nus que pudessem excitar a imaginação. Já entre as causas sociais, criticou as condições de vida das mulheres ricas, cuja ociosidade podia ser nociva para a saúde 
física e moral. As mulheres pobres eram, segundo sua análise, mais afetadas pelo vício porque viviam em ambientes mais promíscuos e estavam mais expostas a causas externas. Pouillet refere-se especialmente às costureiras que trabalhavam com máquinas movidas a pedal. Há uma passagem muito interessante que revela tanto o recorte social deste tipo de análise quanto o voyeurismo do autor, que, ao visitar uma fábrica de roupas, percebeu, em meio aos ruídos de centenas de máquinas, um mais acentuado que vinha de uma máquina operada por uma jovem de 18 anos. A descrição que Pouillet faz em seguida é de um espasmo sexual, provocado pelo movimento das pernas da costureira, levando-o a concluir que aquele tipo de máquina era prejudicial à saúde das operárias, não pelo excesso de trabalho ou pela insalubridade das fábricas, mas porque era uma causa da masturbação.

O capítulo dos sinais é um exemplo da extensão da definição patológica da sexualidade feminina, bem como da importância do olhar médico treinado para reconhecer os sinais. Praticamente, qualquer sintoma físico ou comportamental cabia dentro do mapeamento semiológico de Pouillet. A cor da tez, o emagrecimento, a maneira de andar, tremores, suores, sufocamentos, taquicardia, dores de cabeça, gastralgia, sonhos voluptuosos ou pesadelos terríveis, e tantos outros sinais eram indicativos da masturbação. Da mesma forma, uma tristeza inexplicável ou a inaptidão para o trabalho, o amor pela solidão, a preguiça, a mentira, abraços e carícias exageradas entre jovens mulheres, enfim, "um certo aspecto, um não sei quê mais fácil de perceber do que de explicar por palavras" (1897: 87-88) eram os sinais morais e intelectuais do vício genital entre as mulheres. Se associado a estes sinais o médico percebesse alterações nos órgãos genitais, não devia ter mais dúvida quanto ao diagnóstico. A amplitude dos sinais era tamanha que Pouillet chegou a dizer que perante uma doença sobre a qual o médico não tinha certeza quanto à causa, no que se refere à mulher, devia suspeitar das "manobras ilícitas" (1897: 88) de sua paciente e dirigir a investigação para este assunto, sem se deixar intimidar por ela.

Se os sinais eram tão diversos, as doenças provocadas pela masturbação cabiam num tratado de patologia. Pouillet lista um número impressionante de doenças, flacidez e descoloração da mucosa genital, passando por metrites agudas, tuberculose, anemia, chegando à epilepsia, a histeria e a idiotia. Sua conclusão é que, "todo o corpo [da masturbadora] parece sofrer de uma decadência precoce" (1897: 172). 
Nesse sentido, Pouillet constrói uma representação da mulher onanista muito semelhante a outra imagem feminina dos discursos masculinos da época: a prostituta. Em ambas, a sexualidade é vista como sendo desregrada e improdutiva. A onanista não compartilha seu corpo na comunhão sexual reprodutiva ao buscar unicamente satisfazer seus desejos, sendo, portanto, esta conduta considerada uma anomalia. A prostituta, por sua vez, era a representação do desregramento feminino, fonte de contágios e de dissipação das energias masculinas, símbolo da sexualidade estéril por nada produzir a não ser dinheiro. Dentro da visão funcional da sexualidade, os corpos da onanista e da prostituta foram transformados em símbolos de decadência e de degeneração; corpo fértil somente de doenças, como diziam os médicos. Somente no desvio homens e mulheres eram equiparados numa condição patológica igualitária, pois os homens masturbadores e os homossexuais eram vistos pelos médicos como criaturas fracas de corpo e de caráter, dominados pelos impulsos mais primitivos da Natureza, tal qual as mulheres.

Um corpo débil e doente precisava ser tratado. Pouillet recomendava um tratamento preventivo, seguindo as prescrições higienistas quanto aos cuidados com a alimentação, o vestuário, a educação e a vigilância dos comportamentos das crianças. Caso o mal já estivesse instalado, o médico recomendava a vigilância extrema ou o uso de certos medicamentos com propriedades sedativas. Se estas medidas não fossem eficazes, era necessário passar para uma terapêutica mais drástica, como o uso de aparelhos ou vestimentas que impedissem a manipulação, ou então, em casos mais extremos, a clitoridectomia. Embora este procedimento não tenha tido muitos adeptos, alguns médicos fizeram esta cirurgia mutiladora tanto em mulheres casadas como em jovens e meninas, conforme narrou o Dr. West (1870).

Pouillet afirma que recorria a esta operação para remediar a grande lubricidade das mulheres, considerando o procedimento absolutamente correto, pois, segundo sua interpretação, a clitoridectomia não significava a perda da sensibilidade erótica, tendo em vista os relatos da masturbação vaginal e uterina apresentada por ele no livro. Embora fosse adepto desta cirurgia, Pouillet vinha também desenvolvendo um tratamento químico para crianças e jovens mulheres: a cauterização com nitrato de prata sobre a superfície da vulva e do clitóris. Segundo o autor, este procedimento era eficaz porque produzia dor cada vez que a mulher se tocasse.

Terapias violentas e mutiladoras como essas não eram comuns e nem foram exclusivas às mulheres; afinal, os homens também foram alvo da 
cruzada antionanista no século XIX e igualmente submetidos ao uso de mecanismos de contenção corporal, de substâncias químicas e de eletroterapia.

O que torna o livro de Pouillet emblemático no discurso médico a respeito da sexualidade feminina é a assimetria desmesurada entre a representação da mulher normal e a da mulher doente ou perversa. O que ambas têm em comum é a centralidade do corpo, seja no exercício da sexualidade normal, seja no desvio patológico da histérica ou da masturbadora. Contudo, há um abismo entre as duas, pois a definição de normal tem limites muito restritos e, como mostrou Pouillet, qualquer sintoma físico ou comportamento inadequado caía na ampla rede nosográfica descrita no livro.

Pode-se concluir que a histerização do corpo da mulher propiciou a constituição de um corpo de especialistas na diversidade das patologias então consideradas inerentes à natureza feminina. O campo parecia ser muito promissor para os médicos; afinal, se as mulheres eram doentes por natureza, formavam um grupo de pacientes bastante numeroso e complexo. A abertura da caixa de Pandora, antes de trazer desgraças e destruição, trouxe novos conhecimentos, propiciou a constituição de mais um campo do saber e de aplicação do poder na superfície deste corpo tão saturado de sexualidade, situado no limiar da normalidade e da patologia. A especificidade da natureza feminina está, portanto, na origem da constituição desta nova especialidade médica que se consolidou nas faculdades de medicina, em associações médicas e na clínica: a ginecologia.

\section{Ginecologia: a medicina do sexo feminino}

As doenças de mulheres eram conhecidas e esporadicamente tratadas por médicos desde a época de Hipócrates. Dificuldades para engravidar e problemas menstruais levavam as mulheres a procurar a ajuda tanto de médicos quanto de parteiras e curandeiros antes da organização de uma especialidade médica que tratasse destes problemas. No entanto, as doenças de origem obstétrica e ginecológica foram, até meados do século XVIII, pouco conhecidas e quase sempre associadas a patologias uterinas ou a desequilíbrios humorais. Os tratamentos disponíveis não eram muitos e de eficácia duvidosa, como as fumigações, as sangrias, o uso de ervas e substâncias minerais e, como parte de medicina popular, havia o recurso à magia e aos encantamentos. 
Da mesma forma que a obstetrícia era praticada pelas parteiras e os cirurgiões, as doenças de mulheres integravam uma prática dividida entre poucos médicos, as parteiras e um grande número de leigos. Esta situação explica por que até meados do século XIX predominava no ambiente médico uma atitude de desconfiança e desprezo por 'especialidades' de cura, geralmente associadas ao charlatanismo devido à predominância de leigos em assuntos como impotência e doenças de mulheres. ${ }^{12}$

Os poucos médicos que tratavam das doenças de mulheres eram, em geral, cirurgiões parteiros, o que explica porque a ginecologia foi uma espécie de apêndice da obstetrícia até a segunda metade do século XIX. ${ }^{13}$ São raros os textos médicos que tratam das doenças femininas se comparados com a profusão de tratados de obstetrícia que aparecem entre os séculos XVIII e XIX. Como pouco se sabia a respeito de problemas ovarianos, do câncer de útero ou sobre a menstruação, as tentativas de explicar as doenças ou as disfunções geralmente recaíam sobre os fatores morais, com ênfase na etiologia sexual. Os médicos acreditavam que havia simpatias entre alguns órgãos, mesmo que distantes, como se pode observar na definição do médico brasileiro Cândido Brandão de Souza Barros (1840: 5): "Simpatia é a relação que existe entre as ações de dois ou mais órgãos, mais ou menos remotos e que estabelece entre eles uma sorte de associação, por meio da qual a vitalidade de uns se acha modificada pelo estado mórbido ou fisiológico dos outros".

Essa teoria fundamentava as etiologias morais ou sexuais para as doenças de mulheres bem como os tratamentos indicados. A presença de corrimentos vaginais podia ser interpretada como um sinal da excitação nervosa decorrente da leitura de romances ou então da prática da masturbação. Doenças uterinas e ovarianas encontravam explicação ora nos excessos sexuais, ora na abstinência, bem como se procurava no comportamento e no temperamento das mulheres as causas para suas mazelas ginecológicas. Os tratamentos variavam entre prescrições de regras de higiene, terapias localizadas e regras comportamentais. Sangrias, dietas rigorosas e o uso de purgantes eram as terapias mais utilizadas, mas também prescreviam-se escalda-pés, aplicação de sanguessugas nos órgãos genitais e de ventosas nos seios, proibição de leitura de romances e do consumo de café e de bebidas alcoólicas. Evidentemente, tais prescrições não tinham eficácia e, na maioria das vezes, acabavam contribuindo para o agravamento das doenças. Pode-se entender por que poucas mulheres procuravam os médicos, preferindo as práticas curativas leigas que não causavam tanto sofrimento e não eram tão restritivas. 
Essa situação descrita nos livros de história da medicina como sendo a época heróica do exercício profissional, prevaleceu até a segunda metade do século XIX. A partir de então, vários centros importantes de ensino médico, localizados na Inglaterra, Escócia, França, Alemanha e Estados Unidos, deflagraram pesquisas e desenvolveram técnicas cirúrgicas que revolucionaram a prática conservadora da ginecologia. Uma explicação plausível para esta alteração de rumos pode ser a competição entre os médicos e o estabelecimento de competências. Como os médicos parteiros também tratavam de doenças ginecológicas, os cirurgiões passaram a condenar o que para eles era uma ingerência no seu campo. Portanto, a constituição da ginecologia não pode ser dissociada das disputas profissionais, embora estas não tenham ocorrido em todos os lugares, mesmo porque muitos obstetras adeptos da cirurgia acabavam tratando de doenças ginecológicas, como aconteceu no Brasil, onde não houve conflitos entre os especialistas, sendo regra que o mesmo profissional exercesse as duas especialidades.

Já as leituras feministas sobre a cirurgia ginecológica apontam para seu caráter punitivo tendo em vista alguns relatos médicos sobre o árduo e longo processo para desenvolver uma técnica cirúrgica. Esses relatos foram apressadamente interpretados pelas historiadoras como evidência de uma visão culturalmente hostil às mulheres, 'cobaias' dos mais famosos cirurgiões da época, como James Sims, que desenvolveu a técnica cirúrgica para as fístulas vesicovaginais depois de muitas tentativas fracassadas. Esta análise tem seus fundamentos, pois toda a constituição de um novo campo do saber envolve, necessariamente, relações de força, afinal não foi mera coincidência que a ginecologia moderna tornou-se uma prática quase que exclusivamente masculina. No entanto, não se pode subestimar os problemas que as mulheres do passado sofreram e os esforços sinceros que muitos cirurgiões fizeram a fim de ajudá-las a ter uma vida normal. Muitos cistos ovarianos eram tão grandes que não podiam ser puncionados, exigindo uma intervenção cirúrgica. Tumores uterinos e fístulas vesicovaginais causavam dores terríveis, dificultando muito a vida das mulheres.

Cronologicamente, a cirurgia ginecológica começou a ser praticada com mais freqüência entre as décadas de 1860 e 1870, e no final do século cirurgiões de vários países, entre eles o Brasil, já dominavam bem as técnicas cirúrgicas. No último quartel do século XIX, a ginecologia adquiriu estatuto próprio, separando-se da obstetrícia, embora ainda muito integradas na prática e no ensino, como explicou Dr. Ernest Bumm (1914: 14): 
As duas ciências se completam e é por isso que hoje elas são objeto de um ensino paralelo e simultâneo. É por isso que a antiga maternidade se tornou a moderna clínica de mulheres, na qual se tratam de todos os processos fisiológicos e patológicos relativos aos órgãos genitais femininos.

Da mesma forma que a obstetrícia, a constituição da ginecologia exigiu uma transformação nos métodos de investigação do corpo feminino, inserindo-o num regime de visibilidade obrigatória por meio do exame e da cirurgia. Com estas transformações, produziu-se um saber específico que esquadrinhou o corpo, direcionando o olhar da superfície para o interior, num processo crescente de intervenção e objetivação. Os tratados de ginecologia são, portanto, representações destas transformações no campo dos saberes ao mesmo tempo em que nos informam sobre as realidades corporais das mulheres do passado.

De uma forma geral, os livros escritos após a década de 1860 apresentam uma divisão de capítulos que são indicativos da construção deste saber. Mais do que a obstetrícia, a ginecologia precisou aperfeiçoar a conjugação dos sentidos do olhar e do tato, principalmente do olhar, para observar alterações dos órgãos internos e também para realizar aplicações medicamentosas. Se boa parte do conhecimento ginecológico foi informada pela sala de autópsias e pelo laboratório de patologia, foi o exame realizado nas pacientes que forneceu a maior parte das informações que permitiram aos médicos estabelecer os padrões de normalidade e os níveis de patologia.

Contudo, o aperfeiçoamento dos métodos visuais da ginecologia não pode ser entendido somente como parte do progresso ou avanço do conhecimento. Há que se situar a objetivação do corpo feminino tendo como referência o contexto sociocultural no qual este conhecimento adquiriu sentido. Mais ou menos na mesma época em que a ginecologia começava a ser praticada como especialidade médica, pesquisas sobre o funcionamento dos órgãos sexuais femininos e seu papel na reprodução estavam começando a abalar antigas crenças e teorias a respeito da sexualidade feminina. Estudos no campo da fisiologia da menstruação pareciam confirmar a correlação entre a mulher e a Natureza que os médicos e cientistas iluministas já haviam apontado. ${ }^{14}$

Marcia Pointon (1986) explica que os estudos sobre os segredos da geração da vida são indicativos de um verdadeiro fascínio pela configuração interna do corpo feminino, tendo em vista que na época pouco se sabia da participação feminina na fecundação. Estas incertezas a respeito da fertilidade 
levaram médicos e fisiologistas a procurar no interior do corpo feminino as respostas sobre a ovulação, a fecundação, enfim, a origem da vida, tornando seu interior visível e inteligível.

Divulga-se, na mesma época, séries de pranchas anatômicas dos órgãos sexuais femininos com pormenores detalhados. A visão de algumas destas pranchas levou Michelet (1995) a expressar sua attendrissement religieux ao que ele chamou de retrato interior do corpo feminino, uma visão que inspirou a seguinte descrição: "Oh, doce, sagrado, divino mistério" (Aron, 1980: 157). ${ }^{15}$

Nesse sentido, é importante destacar o vocabulário usado pelos médicos. Verbos como penetrar, observar, domar e olhar foram reveladores da imagem que os médicos tinham do corpo feminino como um território a descobrir, mas também de si mesmos, como agentes deste processo de conhecimento-descobrimento. Este vocabulário foi interpretado pelas feministas como expressão do voyeurismo médico, admitido pelos próprios, como explica Dr. Montgomery (1997: 31): “Confesso que há um certo voyeurismo em todos nós, ginecologistas. Somos autorizados a olhar, vasculhar e tocar no corpo da mulher. Este voyeurismo ultrapassa o corpo. Entramos, também nos segredos mais íntimos da alma feminina".

Autoras como Ludmilla Jordanova (1989), Elaine Showalter (1993) e Marcia Pointon (1986) lembram que a produção do conhecimento médicocientífico sobre o corpo feminino no século XIX é inseparável da produção do imaginário sobre a mulher em outros domínios da cultura. De acordo com Showalter (1993), a análise da literatura médica, da ficção e da pintura do século XIX mostra como se tornou comum o tema da abertura do corpo da mulher e a sua transformação num caso a ser estudado e explicado. Na época em que a ginecologia começava a se tornar uma especialidade, a representação do corpo feminino era, portanto, a expressão de um desejo mais generalizado de conhecer seus mistérios e, nessa direção, os ginecologistas procuraram revelá-los à luz da ciência ocular. Como disse Dr. Murphy (apud Moscuscci, 1993: 31), ginecologista inglês, "a ginecologia moderna podou da genitália feminina os seus mistérios ao examiná-la com o toque e a visão, atacando com sucesso as suas doenças com o auxílio do bisturi e das tesouras" (1993: 110). ${ }^{16}$

Vejamos, então, como o corpo feminino foi inserido no campo visual do conhecimento médico. Vamos analisar inicialmente os livros de ginecologia e suas representações deste corpo, já que por meio deles este conhecimento 
foi comunicado para outros médicos, para os estudantes e para o público masculino leigo, como Michelet (1995), para quem os médicos eram os mais habilitados a emitir verdades sobre as mulheres.

Se comparadas com os livros dos séculos anteriores, as publicações médicas do século XIX se distinguem primeiramente pelo caráter experimental, pela sustentação dos argumentos em observações seriadas - as estatísticas médicas -, pela preocupação em estabelecer comparações e criar modelos explicativos consistentes até que uma nova teoria os suplantasse. Em contrapartida, diferem bastante de seus antecessores pelo estatuto privilegiado do olhar, expresso pelas imagens em números cada vez maiores a partir da segunda metade deste século. Quanto mais especializada se tornava a ginecologia, mais realista eram as representações do corpo feminino e mais limitado era o uso dos livros para um público de iniciados: os médicos e os homens cultos.

Escritos para este público, os livros de ginecologia têm um caráter secreto, confidencial, como se fossem uma extensão do segredo médico para as páginas impressas. Da mesma forma que a sexualidade feminina devia ser restrita à intimidade do casamento, sua representação dava um caráter privado para aqueles livros. A preocupação com o uso dos livros fez com que o Dr. Puillet comentasse, no prefácio do seu livro sobre masturbação, que não tem imagens, ter alterado o título para Onanismo por ser esta uma palavra que poucas pessoas conheciam o significado, afastando os curiosos do tema real do livro.

Os médicos temiam que os segredos que só eles conheciam acabassem se tornando públicos e contribuíssem para o despertar da volúpia através da observação das imagens. Talvez estes livros tivessem realmente outros usos, como lembra Ercília Nogueira Cobra (1996: 109-110), escritora brasileira do início do século XX:

Era eu menina. Estava no colégio. Colégio de freiras, tudo quanto há de mais severo a respeito das sensações carnais. (...) Uma das minhas camaradas, que pela estatura reduzida estava ainda na classe das pequenas, deliciava-me a mim e a umas três ou quatro amigas, no raconto de coisas vistas nas férias, na biblioteca do seu irmão médico. E o que mais divertia a pequena taluda eram os livros de obstetrícia, onde se trata do capítulo Partos. Estes livros abundantemente ilustrados, que faziam a sua delícia a avaliar pelos pormenores com que descrevia as gravuras, quer-me parecer eram seus livros de cabeceira.

Em suas memórias de colegial, Ercília Cobra destaca a abundância de imagens que despertara o interesse de sua colega indiscreta cujo acesso aos livros só foi possível porque seu irmão era médico. Sua colega, como o 
jovem monge do livro O Nome da Rosa, de Umberto Eco, atrevera-se a entrar numa biblioteca privada e ter acesso aos conhecimentos destinados aos doutores. Era esta intromissão leiga que os médicos-autores temiam, pois os assuntos tratados e as imagens expostas não eram de domínio público, mas do colégio de iniciados nos segredos da natureza feminina.

Diferentemente dos livros renascentistas ou mesmo de alguns exemplares dos séculos XVII e XVIII, os livros de ginecologia do século XIX não recorriam a nenhuma alegoria, a nenhum simbolismo. Suas imagens são muito realistas, reveladoras de um olhar desimpedido de convenções artísticas ou de pudores. Nesse sentido, eles são fruto da produção cultural oitocentista, essencialmente visual.

O que chocava nos livros era a perspectiva adotada; imagens da genitália feminina que não são normalmente visíveis nem pelas próprias mulheres, especialmente numa época em que, tanto na vida privada do lar, quanto na vida pública de saraus, bailes, passeios, teatros e cultos religiosos, a regra era a extrema segregação sexual no vestuário, acompanhada da reclusão dos corpos em roupas cada vez mais discretas e fechadas. No que tocava ao corpo, a regra era a ignorância, a contenção e o ocultamento. ${ }^{17}$

Ao contrário, nos livros a regra é a visibilidade, o desvelamento do corpo em detalhes cada vez mais minuciosos, conforme a especialidade foi se legitimando no ambiente acadêmico. Portanto, quanto mais científica se tornava a ginecologia, mais objetivos os textos e mais realistas as imagens apresentadas para acentuar o caráter neutro da ciência da mulher.

No entanto, se inseridas no conjunto da produção cultural oitocentista, no qual proliferam imagens diversificadas do corpo feminino, observa-se que as imagens científicas se revestem de um significado peculiar aos olhos dos seus observadores privilegiados. Se as artes plásticas desvelavam os corpos de ninfas, banhistas, dançarinas e de jovens mulheres num inocente piquenique (lembremos da tela Déjuneur sur l'herbe - tela pintada por Edouard Manet em 1863, exposta no salão dos recusados no mesmo ano), contribuindo para o conhecimento carnal, como disse Peter Gay (1988), este desvelamento revelava a beleza e a sensualidade dos contornos pintados ou esculpidos, verdadeiros estimulantes para a imaginação. Já as imagens médicas do corpo feminino não deviam servir para estes exercícios eróticos visuais; ao contrário, eram objetivações da sexualidade feminina, localizada nos órgãos genitais, que, de tão detalhados e despidos de qualquer simbolismo, tinham de ficar distantes do público 
leigo, a fim de mantê-las sobre a rubrica da seriedade deserotizante da ciência ginecológica.

Essa aura de segredo envolvendo os livros de ginecologia e obstetrícia contribuiu para a construção da imagem do médico como o 'guardião' dos segredos da feminilidade, o homem da ciência que podia explicar a mulher porque a conhecia no seu próprio território, já mapeado pela topografia ginecológica. Para os homens cultos do século XIX, o médico era o mais indicado para proteger a mulher de sua instável natureza, pois, pensava-se, então, que ele havia descoberto sua verdade: a mulher era o seu corpo e sobre este se dirigiam os olhares e as práticas.

A produção dessas representações se deu por meio de dois importantes procedimentos: o exame visual e a intervenção cirúrgica, repetindo a mesma trajetória da dissecação, ou seja, da superfície para o interior do corpo.

Vimos como os obstetras enfrentaram o problema da resistência das parturientes em se expor aos exames e como cederam ante os argumentos médicos em favor do bem-estar da mãe e do bebê. Já os ginecologistas enfrentaram o problema do pudor feminino sem ter argumentos tão convincentes, pois a idéia de se expor a um exame ginecológico era insuportável para a maioria das mulheres, segundo os autores dos livros de ginecologia. Nas suas lições sobre o exame ginecológico, o Dr. West (1870: 12) explicava aos alunos que este era muito penoso para as mulheres:

A mulher reage com grande sensibilidade às impressões penosas e sente-se profundamente atormentada e humilhada diante da perspectiva de um exame, embora ela compreenda a necessidade de fazê-lo, mas ela julgará com um tipo de perspicácia mórbida cada um dos seus (dos médicos) atos. A maior circunspeç̧ão não lhes preservará de uma acusação imerecida.

Para West, todo o cuidado era pouco para evitar ofender a mulher e dar a impressão de que a ginecologia era uma especialidade incompatível com as boas maneiras de um homem culto. A aceitação dos exames por parte das mulheres deve-se ao paciente trabalho de convencimento e de aceitação da autoridade dos médicos. Da mesma forma que o obstetra passou a ser aceito na cena do parto, o ginecologista conseguiu, aos poucos, conquistar a confiança das mulheres.

De acordo com Jean Pierre Peter (1981), este processo começou na burguesia, para quem o médico era um semelhante, um modelo, uma autoridade que passou a ser tão respeitada pela mulher quanto a figura do marido. Essa conquista se deve também à habilidade dos médicos em expor 
suas idéias, procurando convencer, através do uso de uma linguagem acessível, atitudes corteses e paciência em explicar seus procedimentos, como se pode perceber nesta passagem a respeito do exame ginecológico:

Se através de sua atitude você mostra que o exame não tem nada de insólito; se você permanece calmo, sério e digno; se após ter tomado o pulso, auscultado o pulmão e o coração, apalpado o ventre você pede naturalmente que é necessário fazer o toque vaginal, a mulher nem pensará em negar ao médico o exame, mesmo sendo um homem, ela se abandonará sem reservas a todas as explorações que ele julgar úteis. (Leblond, 1878: 2)

Apesar da anamnese ser parte essencial da experiência clínica, os livros de ginecologia trazem poucas informações sobre o interrogatório, o que é indicativo de como o relato da paciente é apenas o ponto de partida para a investigação propriamente dita, que tinha como objetivo tornar inteligível o conjunto 'desconexo' das informações da paciente. Desta forma, recorremos a um autor brasileiro, Dr. José Adeodato de Souza, professor de ginecologia da Faculdade de Medicina da Bahia no início do século XX, cujo questionário foi reproduzido por seus alunos nas teses de doutoramento e por ele mesmo no livro Propedêutica Gynecológica (1929).

Para o Dr. Adeodato, a anamnese era apenas uma fase do exame, de importância relativa, dependendo do "grão de capacidade intellectual" das mulheres e da "excessibilidade do pudor feminino" (Ramos, 1918: 6-7). As perguntas dirigidas às pacientes deviam ser formuladas com destreza, para evitar indiscrições que pudessem afetar os sentimentos e o pudor; como explica seu aluno Haroldo Ramos (1918: 5),

muito do sucesso da anamnese dependia da conduta do ginecologista: o ginecologista nunca perderá em ser minudente; ele deverá agir com toda a prudência, tato, critério e autoridade, revestindo-se ao mesmo tempo de uma educação psíquica especial a fim de bem conduzir-se na sua tão elevada quão nobre profissão.

De acordo com o questionário ginecológico do Dr. Adeodato de Souza, podemos observar as duas fases do exame; a anamnese e o exame físico e ginecológico propriamente dito.

- Exame subjetivo ou interrogatório: de que se queixa a doente; idade; estado sexual (virgem, nulípara, multípara); menstruação; corrimentos; dores; perturbações uretrovesicais; perturbações anoretais; antecedentes pessoais (partos e abortamentos, moléstias conjugais, molétias de infância); antecedentes hereditários; funções gerais (psiconervosa, 
digestiva, circulatória, respiratória, urinária, febre, calafrios, emagrecimento); evolução da moléstia.

- Exame objetivo: inspeção geral; pulso e temperatura; percussão e auscultação; aparelho respiratório; aparelho circulatório; aparelho nervoso; exame do abdomen (fígado, baço, rins, intestinos, apêndice, tumores); exame das mamas (inspeção e apalpação); exame dos órgãos genitais externos (inspeção e apalpação); exame dos órgãos genitais externos (toque, inspeção especular, exames complementares). (adaptado de Souza, 1929: 310-311).

Ao comentar a primeira fase, o doutorando Ramos, seguindo as orientações de seu mestre, volta a sublinhar a importância da atitude do médico diante da mulher. Embora saliente que muitas vezes as mulheres narram histórias enfadonhas trazendo para o interrogatório informações inúteis, o médico devia ser paciente e atencioso. Explica que, além de bom ouvinte, o médico devia familiarizar-se com a linguagem de certas pacientes que muitas vezes "atiram-nos em verdadeiros labirintos de frases ambíguas que não traduzem a realidade dos fatos" (Ramos, 1918: 8).

A preocupação com a qualidade do relato da mulher está presente em outros autores, como o famoso obstetra brasileiro do início do século XX, Dr. Fernando Magalhães (1933). Falando como perito, ele diz que, para a anamnese ser proveitosa, deve ser "impertinente, severa, inquisitorial" (1933: 32). A rigidez exigida pelo Dr. Magalhães deve-se ao fato, por ele mesmo esclarecido, de que a paciente podia sonegar informações que porventura considerasse colocar a descoberto algum comportamento sexual socialmente condenável. Portanto, mesmo sendo a anamnese uma fase indispensável do exame, seu valor era reduzido em relação ao exame físico, pois dependia do testemunho da mulher e, como alertava o Dr. Magalhães, havia um velho axioma clínico que não podia ser esquecido: as mulheres enganam.

Essas observações são esclarecedoras do estatuto dos sentidos na construção do saber clínico. Todo o conjunto de procedimentos que leva ao diagnóstico se fundamenta na relação entre olhar e o relato. Como vimos, o relato da paciente depende de muitas variáveis subjetivas (capacidade intelectual, receio em expor segredos íntimos, pudor, vocabulário confuso), portanto, a audição do médico nesta fase do exame se presta para começar a construir a rede semiológica que o levará ao enunciado do diagnóstico. A fase mais importante, que o Dr. Adeodato de Souza (1929) qualificou como exame objetivo, foi minuciosamente discutida nos livros de ginecologia. 
Pode-se afirmar que as informações obtidas desta fase constituem, strito sensu, o saber ginecológico.

O exame objetivo não mais depende da mulher. Ela é, a partir de então, paciente, no sentido original desta palavra, ou seja, a pessoa que sofre ou é objeto de uma ação sobre seu corpo praticada por um agente, que, munido do saber e dos instrumentos que só ele conhece e pode manejar, toca, ausculta e olha, dando início à jornada do conhecimento que vai da superfície do corpo ao interior da genitália feminina, o locus de sua essência, mas também de suas patologias. Nessa direção, os livros de ginecologia são verdadeiros arquivos de descrição dos exames objetivos, do arsenal de instrumentos criados e de suas aplicações, das patologias e das intervenções realizadas nos corpos femininos.

A técnica do exame começava pela palpação abdominal com a mulher deitada de costas e vestida, pois o contato da mão do médico com a pele da paciente devia ser evitado. O Dr. West (1870) explicava aos alunos que só em raras ocasiões se aplicava a mão sobre a pele e que o médico devia iniciar uma conversa com a paciente para desviar a sua atenção do exame.

A exploração manual tinha continuidade com o toque vaginal. Quando ainda predominava na medicina o princípio do 'toque, mas não olhe', este exame era realizado com a mulher em pé ou deitada, vestida e sem contato visual com o médico, que, por sua vez, cercava-se de cuidados ao realizar o toque, não descobrindo o corpo da paciente, que, completamente vestida, cobria o rosto para evitar o contato visual com o respeitável senhor que a examinava. No entanto, com a necessidade da exploração do corpo através do olhar, foi necessário mudar esta cena, adaptando a posição da mulher para o exame e criando novos instrumentos que ampliassem o campo visual do médico.

A posição ginecológica conhecida atualmente só foi aceita entre os próprios médicos em situações muito específicas, quando o diagnóstico pelo toque se mostrava infrutífero. Foram desenvolvidas poltronas especiais para o exame visual que, quando abertas, se transformavam em plataformas elevadas com pedais para sustentar os pés, permitindo ao médico a utilização de instrumentos de exame e até mesmo a realização de pequenas operações.

Para fazer a exploração visual foram desenvolvidos instrumentos que eram a extensão da mão e do olho do médico. Ao longo do século XIX, os ginecologistas criaram uma grande diversidade de instrumentos, mas o 
mais famoso deles é o espéculo, que permite ao médico observar o colo do útero. O espéculo foi um instrumento utilizado na Antiguidade para aplicar medicamentos no interior do canal vaginal e existem ilustrações nos antigos tratados de partos em que eram denominados speculum matricis. Até o início do século XIX não era um instrumento de exame visual e pouco empregado na prática. Foi o médico francês Récamier que, em 1821, transformou o espéculo para que fosse usado na exploração visual do útero, sendo, em seguida, várias vezes modificado pelos ginecologistas que o adaptaram aos diversos procedimentos e às necessidades dos exames. ${ }^{18}$

Apesar do interesse dos médicos e da disponibilidade de vários tipos de espéculos, o exame com este instrumento gerou reações entre os próprios médicos e, na Inglaterra em especial, entre ativistas dos direitos das mulheres e algumas médicas. ${ }^{19}$ A polêmica em torno do uso do espéculo é, por um lado, a expressão dos pudores femininos e dos médicos que ainda não estavam convencidos da necessidade de olhar os genitais, confiando somente no tato. Por outro lado, a questão envolvia também divergências quanto às terapêuticas ginecológicas utilizadas na metade do século XIX. Cirurgiões ingleses e especialmente norte-americanos estavam convencidos de que as doenças ginecológicas, com exceção do câncer e cistos ovarianos, decorriam de um processo inflamatório no útero. Tal explicação era a base de Teoria de Bennet, ${ }^{20}$ que teve larga aceitação, apesar das severas críticas que suscitou, especialmente por parte do Dr. West e de alguns cirurgiões franceses como Mauriac e Leblond.

Com a divulgação do espéculo como instrumento de exame a partir da década de 1840, muitos seguidores de Bennet passaram a utilizar o espéculo para fazer tratamentos antiinflamatórios no colo do útero, como cauterizações com o calor e agentes corrosivos, além das amputações: "A Teoria de Bennet não resistiu, mas as cauterizações do colo dela derivada resistiram mais tempo" (West, 1870: 5). Segundo Mauriac (apud West, 1870), muitos médicos inexperientes produziram doenças nas mulheres ou agravaram as lesões que deveriam ser curadas. Para este autor, foi o uso do espéculo que, manejado pelos cirurgiões, particularmente, propiciou pesquisas mais audaciosas e métodos mais agressivos como amputações e cauterizações.

O Dr. West não rejeitava o uso do espéculo para fazer exames, mas era cauteloso, salientando a eficácia do toque, que criava menos embaraço para as mulheres, já que podia ser feito sem a exposição do corpo e com a mulher em pé. Quando o exame manual era insuficiente, ele recomendava 
a exploração visual do útero com o espéculo. Explica que a mulher devia ficar na posição ginecológica, "mas a indecência da posição é uma objeção tão séria que, com exceção de situações particulares, é preferível introduzir o espéculo com a mulher deitada de lado" (West, 1870: 21).

Para West e outros cirurgiões ginecologistas, a questão sobre o uso do espéculo não derivava de algum malefício que o instrumento pudesse causar, muito menos das intenções desonestas dos médicos, mas sim dos abusos terapêuticos que a facilidade de acesso ao útero podia propiciar.

Contudo, a prática dos exames ginecológicos não foi aceita facilmente. A bibliografia que aborda as relações entre médicos e pacientes no alvorecer da medicina clínica mostra como as mulheres nem sempre eram 'pacientes', recusando-se aos exames com instrumentos, já que este procedimento, além de ser mais invasivo e exigir maior exposição do corpo, reavivava antigos receios de ser usada para experiências científicas. ${ }^{21}$

Percebe-se, pelo relato dos médicos, que os exames ginecológicos sofreram restrições devido a impedimentos de ordem moral, pois não podemos deixar de levar em conta as dificuldades da época no contato das mulheres com seus próprios corpos, cercados de tabus, restrições e cobertos com muita roupa. Portanto, pode-se imaginar a dificuldade em expor os órgãos genitais mesmo que fosse num ambiente deserotizado e com a presença de terceiros.

O Dr. West (1870) comenta que na sua prática hospitalar observara que a sensibilidade aos exames era maior entre as mulheres de classes sociais mais elevadas, exigindo delicadeza por parte do médico. Certamente o Dr. West não defenderia atitudes menos dignas ou descortesia para com as mulheres do povo que procuravam os hospitais londrinos, mas esta observação mostra a preocupação dos médicos em não ferir suscetibilidades de classe, especialmente numa época em que os médicos procuravam criar uma imagem respeitável para a profissão e ampliar a clientela entre as mulheres da burguesia.

Além do espéculo, um verdadeiro arsenal foi inventado e aperfeiçoado para a execução dos exames uterinos e cirurgias, composto por vários tipos de pinças, tesouras, histerômetros, sondas, dilatadores, enfim, um amplo conjunto de instrumentos que foram necessários à medida que o nível de intervenção no corpo da mulher se aprofundou. A cirurgia ginecológica foi o passo seguinte na senda do conhecimento ginecológico. 
Segundo os médicos, os problemas menstruais e as doenças sexualmente transmissíveis eram a origem da maior parte das queixas das mulheres, no entanto, quatro grandes problemas pareciam desafiar qualquer terapêutica: os tumores ovarianos, o câncer, o prolapso do útero e as fístulas vesicovaginais. A história oficial da ginecologia é, na verdade, narrada a partir das técnicas desenvolvidas pelos cirurgiões que se dedicaram a estes males: Ephraim McDowell, Charles Clay, Charles Péan, Wilhelm Freund e James Marion Sims.

Embora esses nomes sejam os mais destacados, a cirurgia ginecológica começou a ser largamente praticada na segunda metade do século XIX, tanto que muitos médicos passaram a questionar a transformação da ginecologia numa especialidade cirúrgica e a criticar abertamente os excessos. Este debate revela como os médicos estavam longe de constituir uma categoria homogênea quanto à definição de suas atribuições, às teorias que fundamentavam suas práticas e à conduta profissional. Revela também as diferenças entre as escolas, dividindo médicos norte-americanos, ingleses e franceses.

Nos três países a ginecologia encaminhou-se para a cirurgia, mas nos Estados Unidos e na Inglaterra esta tendência foi mais acentuada. Médicos como West e seu colega francês Mauriac engrossavam o coro dos críticos ao intervencionismo cirúrgico na especialidade que estava perdendo sua característica preventiva. Pregando a moderação, Mauriac (apud West, 1870: 9) exortou seus colegas para o que ele considerava uma questão de ordem:

A escola ginecológica americana, recentemente importada por nós, parece nos colocar na via das tentativas aventureiras. Parecem ter a palavra audácia como divisa. Mas nem sempre a audácia é bem-sucedida; ela não justifica certas práticas que não serão aceitas, eu espero, na França, apesar do fervor. Faço menção aos novos métodos terapêuticos, como exemplo, no tratamento da dismenorréia e da esterilidade, empregados por James M. Sims. Depois dele, toda a dismenorréia é mecânica, isto é, deve-se a um processo mórbido que tem por resultado a obstrução do canal cervical. Tal visão das coisas leva, logicamente, a um tratamento cirúrgico. (...) Há que se utilizar desta escola o que há de bom mas sem desprezar as grandes tradições patogênicas e terapêuticas da ginecologia francesa. ${ }^{22}$

Essa passagem é bastante representativa dos debates que ocorreram entre as escolas de ginecologia e entre os próprios médicos nos seus países de origem. É importante ressaltar que entre as décadas de 1840 e 1890 foram fundados vários hospitais, enfermarias e dispensários especializados em tratar doenças de mulheres, locais que propiciaram as condições 
adequadas para a prática ginecológica e o desenvolvimento de pesquisas e técnicas como a cirurgia, por exemplo. ${ }^{23}$ Os resultados obtidos desta experiência clínica foram divulgados amplamente no ambiente da medicina devido à organização dos ginecologistas em associações e ao crescente número de publicações especializadas nos dois continentes. Dessa forma, o debate sobre a propriedade ou não das cirurgias ginecológicas tinha todas as condições materiais e intelectuais para ocorrer, expondo as idéias médicas a respeito do seu objeto de estudo e as divisões internas da profissão.

Boa parte das discussões que ocorreram entre 1870 e 1890 foi motivada pela ovariotomia. Resumidamente, esta cirurgia foi desenvolvida para tratar de tumores ovarianos, mas no período em questão foi largamente utilizada para tratar de outras doenças. Tendo em vista a amplitude da definição patológica da sexualidade feminina - lembremo-nos do livro de Pouillet (1897) - e de uma bem consolidada tradição que localizava as doenças femininas no útero, não foi estranho aplicar o mesmo raciocínio para o papel dos ovários na definição de saúde ou de doença para as mulheres. Assim, muitas delas ficaram sem seus ovários na fase de expansão da cirurgia ginecológica, tanto que há vários relatos de operaçoes deste tipo e de histerectomias e clitoridectomias realizadas para curar a ninfomania, a masturbação e doenças mentais. ${ }^{24}$

Além do questionamento da eficácia deste tratamento, os médicos que se opunham aos excessos intervencionistas levantaram questões morais, pois a remoção dos ovários tocava no delicado tema da sexualidade feminina cujos desdobramentos podiam ter significados sociais importantes. O principal alvo da crítica de médicos ingleses e franceses foi a chamada operação de Battey, conhecida também como operação de Hegar, que era a remoção de ovários normais para curar várias patologias com etiologia sexual. A ooforectomia ou ovariotomia bilateral passou a ser chamada por seus detratores de castração da mulher e suscitou reações iradas de cirurgiões importantes como Spencer Wells e a famosa Dra. Elizabeth Blackwell, bem como das feministas que viam na 'castração' uma ameaça à integridade física e moral das mulheres. ${ }^{25}$

Esses discursos alertavam para as conseqüências que a esterilidade acarretaria não só para a mulher individualmente, mas para a sociedade, tendo em vista o papel de reprodutora da espécie tão exaltado pelos discursos masculinos da época e igualmente pelas feministas, que viam na maternidade a fonte da superioridade espiritual e moral das mulheres. A ovariotomia 
indiscriminada chocava-se, portanto, com a ideologia da domesticidade na qual a maternidade era um dos principais pilares, mas também levantava o problema da definição da feminilidade. Fosse definida pelo útero ou pelos ovários, a retirada de um destes órgãos significava, para o pensamento materialista dos médicos, a perda da feminilidade, o que parece ser paradoxal, afinal os cirurgiões que defendiam a ooforectomia procuravam adequar o comportamento de suas pacientes aos padrões morais da época.

Não cabe aqui avaliar os benefícios ou malefícios desta ou de outras cirurgias ginecológicas, mas sim entender sua importância e seu significado no contexto da formação de um novo campo do saber médico-científico sobre o corpo feminino. Por um lado, as discussões sobre ovariotomia e uso do espéculo são indicativas das diferentes visões que dividiam a profissão no que diz respeito aos limites éticos das relações entre médicos e pacientes e da predominância da cirurgia sobre a profilaxia. Pode-se argumentar que estes debates também estavam presentes em outros campos do exercício da medicina, como é o caso da obstetrícia, em que intervencionistas e nãointervencionistas disputavam entre si para impor suas idéias junto a seus pares. No entanto, a cirurgia ginecológica alcançara tal nível de intervenção com a ooforectomia que o debate tingira-se de fortes tons ideológicos, ultrapassando as fronteiras da profissão e da técnica ao questionar seus efeitos sobre o papel social das mulheres.

O sistema sexo-gênero foi consolidado sobre a estreita relação entre a anatomia e a identidade de gênero, e a 'castração' de mulheres criava um desequilíbrio no sistema. A antiga definição latina tão citada nos textos médicos mulier propter uterum condita est ( a mulher é seu útero) foi atualizada para o século XIX para propter solum ovarium mulier est id quod est, (a mulher é tão-somente o seu ovário) reforçando a idéia de que a mulher era o que era por causa dos seus órgãos reprodutivos. Sem os ovários, ela não podia cumprir sua função natural e social de reprodutora da espécie, portanto, tornava-se assexuada, no sentido dado a este termo na época, ou seja, a sexualidade feminina era inseparável da função reprodutiva. A ooforectomia criava uma outra representação da mulher que não cabia no sistema sexogênero, se tomarmos a definição de mulher dada pelo médico psiquiatra e cavaleiro da Legião de Honra, Dr. Berthier (1874: 235):

A mulher, como indica a etimologia (foemina vem de foetare, que quer dizer engendrar) é uma criatura que engendra. Do ponto de vista fisiológico é a depositária dos germes de sua espécie, alma da reprodução, fonte fecunda 
de onde resultam as gerações humanas. Seu papel é imenso e todo seu mecanismo concorre para este fim. Seus órgãos sexuais, para os quais parecem convergir os outros, são a razão e a base de toda a sua estrutura.

Sob esse ponto de vista, médicos, feministas, religiosos e outros partícipes de diferentes matizes ideológicas convergiam no debate sobre a cirurgia ginecológica, pois todos os discursos compartilhavam a mesma certeza de que a mulher é definida pelo seu corpo. Paradoxalmente, a ooforectomia tornava as mulheres mais femininas por extirpar um dos comportamentos inadequados ao sexo feminino. No entanto, a 'castração' causava mal-estar para seus opositores porque tocava no pilar estável das diferenças sexuais assentadas pela ciência. Remover os ovários - o locus da feminilidade - não significava criar mulheres mais 'masculinas'? A ciência sexual e a medicina da mulher formularam discursos para regulamentar a segregação sexual e o estatuto inferior das mulheres na sociedade burguesa tomando como princípio a evidência das diferenças sexuais. Para muitos dos envolvidos na questão, os médicos não tinham o direito de remover ovários saudáveis, produzindo mulheres estéreis e inúteis numa estrutura ideológica armada sobre os papéis 'naturais' de gênero.

Em contrapartida, a cirurgia ginecológica suscitou o debate sobre as relações entre saber-poder que, se não foram assim formuladas na época, foram percebidas como parte das relações assimétricas entre médicos e mulheres-pacientes. O debate em torno do uso do espéculo já havia antecipado esta questão, mas foi a cirurgia ginecológica que despertou críticas de fundo mais político do que científico. A maior parte das denúncias de exploração sexual ou do controle dos médicos sobre as mulheres veio de médicas e de profissionais que não eram cirurgiões ou que praticavam uma medicina não-ortodoxa.

Nos Estados Unidos, a discussão sobre o controle dos corpos femininos era muito mais acirrada do que na Europa. Wood (1973) comenta que as terapias alternativas como a homeopatia e a hidroterapia eram bastante utilizadas por médicas no tratamento de suas clientes. Segundo Elizabeth Phelps (apud Wood, 1973: 52), uma escritora muito popular no período pós-guerra civil, "as mulheres não precisam ser prisioneiras em corpos doentes esperando pela chegada do seu salvador, o homem; pelo contrário, a mulher pode curar a si mesma, apoiar seu próprio sexo e, cuidando de outras mulheres, dar a elas uma nova forma de auto-estima".

Mesmo com alguns discursos abertamente anticientíficos - o que é importante ressaltar destas vozes dissonantes é a compreensão que se tinha, 
na época, um campo do saber sobre o corpo feminino que envolvia muito mais do que a fria técnica e o comprometimento com o avanço da ciência e da medicina; estava em jogo também, o desejo de controlar, por meio de tratamentos que transformavam as mulheres em pacientes, uma categoria social que surge com a medicina clínica do século XIX e que resume muito bem a relação de objetivação do conhecimento e da prática médica.

Apesar das reações, o processo já não tinha mais volta e no final do século XIX a cirurgia ginecológica estava consolidada nos dois continentes e a clínica disseminada pelos hospitais de mulheres e enfermarias. No início do século XX, a ginecologia se havia tornado uma especialidade reconhecida e as publicações da área em nada ficavam a dever aos outros ramos da cirurgia. Em menos de um século as antigas práticas a respeito das doenças de mulheres deram lugar a um campo do saber sobre o corpo feminino muito mais abrangente, bem definido e estruturado. Como ciência da mulher, a ginecologia racionalizou as idéias a respeito da natureza feminina ao transformar o corpo num objeto analisável, mensurável e sujeito às mais diferentes práticas de objetivação. Como medicina da mulher, ginecologia e obstetrícia concluíram o projeto da naturalização das diferenças sexuais que vinha sendo elaborado desde o século XVIII ao encerrar a mulher no seu corpo, justificando a necessidade de um campo do saber, de uma nova ciência que estabelecesse a verdade sobre a alteridade feminina.

Com a medicina da mulher, constituiu-se um amplo e bem documentado arquivo de informações nos países europeus e americanos, ampliado e renovado com as novas instituições de ensino e de atendimento hospitalar criados no final do século XIX e início do século XX. Os centros de ensino e pesquisa europeus formaram também médicos do continente americano, entre eles vários brasileiros que foram estudar nas universidades portuguesas, francesas, inglesas e alemãs, sendo que alguns deles fizeram viagens de pesquisa visitando várias clínicas particulares e freqüentando cursos de médicos famosos como Ernest Bumm, Depaul e Spencer Wells, entre outros.

Trazendo as mais novas informações produzidas na Europa ou desenvolvendo por conta própria novos conhecimentos e técnicas no campo da obstetrícia e da ginecologia, os médicos brasileiros envolveram-se com a produção do saber sobre a mulher, deixando um grande arquivo documental sobre o tema disposto nas bibliotecas das faculdades de medicina, nas publicações médicas e nas centenas de páginas de registros hospitalares um arquivo que abriga a história da constituição da obstetrícia e da 
ginecologia no Brasil e das representações sobre a mulher produzidas pelo discurso médico e científico.

\section{Notas}

1 Cassel (1996) comenta sobre o que poderíamos chamar de um ranking médico no qual os psiquiatras ocupam a posição mais inferior enquanto os cirurgiões posicionam-se nas categorias superiores da profissão devido à proverbial intrepidez no contato mais íntimo com o corpo humano.

2 Apesar disso, na Inglaterra e nos Estados Unidos surgiram grupos ativistas contrários à prática da vivissecção, que é o uso de animais vivos em experiências médicas. Ver Moscucci (1993) e French (1975).

3 A respeito da literatura médica sobre a família moderna, tomo como referência Donzelot (1986), Foucault (1985) e Joseph (1977).

4 As expressões foram citadas, respectivamente, por dois médicos ginecologistas: Montgomery (1997: 53) e Soucasaux (1993: 8-9).

5 Illich (1983) explica que o vocábulo francês le sexe era restrito à segregação das mulheres.

6 Ver em Baptista (1909: 19-20)

7 Sobre a tradição médica anterior ao século XIX, seu vocabulário, práticas e imagens a respeito da natureza instável do corpo feminino, ver Del Priore (1993), especialmente a quarta parte do livro intitulada "O olhar da medicina".

8 A respeito das opiniões médicas sobre a sexualidade e o desejo feminino, ver Degler (1974), Gay (1988) e Cott (1978).

9 Sobre o modelo androcêntrico da sexualidade, ver Maines (1999).

10 Nas teses médicas produzidas no Brasil que tratam da sexualidade feminina, Pouillet é, ao lado de Tissot, citação obrigatória. Tissot foi o autor de um célebre tratado sobre a masturbação, Onania, publicado pela primeira vez em 1760, cuja influência se manteve até o início do século XX.

11 Na sua tipologia, Pouillet (1897: 34) refere-se à masturbação vagino-uterina que seria pouco conhecida pelos franceses, mas muito praticada pelas mulheres ociosas do Japão, da China e pelas odaliscas que viviam no gineceu oriental. O autor explica tal recorte racial pela influência do clima quente, abundância de alimentos afrodisíacos, vida sedentária e reclusa, ou seja, "estas mulheres não têm outro objetivo a não ser gozar." No século XIX, era bastante aceita a idéia de que as mulheres não-européias e as mulheres brancas pobres eram mais promíscuas sexualmente. Ver em Stepan (1994) e Degler (1974).

12 Sobre a prática da medicina por leigos, ver Moscucci (1993) e Ehrenreich \& English (1973).

13 Sobre a crítica ao exercício integrado da obstetrícia e da ginecologia, ver Soucasaux (1990).

14 Refiro-me especialmente ao trabalho de Pouchet - naturalista que estudou o fenômeno da ovulação e autor do livro Théorie Positive de l'Ovulation Spontanée et de la Fécondation des Mamifères et de l'Espéce Humaine, publicado em 1847 - e ao famoso tratato de emenologia de Adam Raciborski, Traité de la Menstruation, de 1868. Ambos foram lidos 
e citados não só pelos médicos, mas também por escritores, entre eles Michelet, um dos divulgadores para o público leigo das teorias de Pouchet e Raciborski no livro O Amor, de 1859. Sobre a teoria da ovulação espontânea, ver Laqueur (1992).

15 Essa passagem foi escrita pelo autor no seu diário em 1849 e citada por Aron.

16 A metáfora da poda é bastante reveladora de como a ginecologia estava, realmente, de acordo com o tema da descoberta da mulher, presente em outros discursos da época, segundo Showalter (1993).

17 Ver em Hobsbawm (1997).

18 Leblond (1878) refere-se a onze tipos diferentes de espéculos em seu livro, cada um devidamente nominado pelo ginecologista que o desenvolveu, como o espéculo de Sims, de Fergusson, de Ricord e tantos outros que surgiram ao longo do século XIX.

19 Sobre o debate em torno do uso do espéculo nas mulheres, ver Moscucci (1993).

20 Na verdade, Henri Bennet não formulou uma teoria, mas revisou e divulgou as idéias de Broussais para quem as doenças consistem "no excesso ou falta de excitação dos diversos tecidos abaixo ou acima do grau que constitui o estado normal" (Canguilhem, 1995: 28). Henri Bennet utilizou esta idéia para explicar as patologias uterinas, ou seja, segundo sua interpretação das idéias de Broussais, todos os problemas uterinos tinham como causa a inflamação do colo do útero.

21 Segundo Moscucci (1993), as críticas de Elizabeth Blackwell, médica feminista e antivivisseccionista, associavam os exames e as cirurgias ginecológicas às experiências com animais. Para esta médica, a crueldade dos médicos com os animais explicava sua determinação em submeter as mulheres a exames vaginais "degradantes". Moscucci comenta que era comum no final do século XIX analogias entre o vivisseccionismo e a ginecologia: "as mulheres e animais compartilhavam o mesmo destino como vítimas do materialismo dos médicos" (1993: 124).

22 Prefácio do livro de West, por Charles Mauriac. A dismenorréia é a dor intensa durante o período menstrual e, segundo Malcom Montgomery, é o fenômeno de maior significado psicológico: "Partindo-se do fato de que a menstruação representa a expressão de 'ser mulher', esta dor pode ser compreendida como a recusa do papel feminino. É a 'dor de ser mulher' resultante de uma representação negativa que se teve deste papel" (Montgomery, 1997: 59).

23 Moscucci (1993: 75) informa que só em Londres foram fundadas 88 destas instituições. Sobre os hospitais de mulheres nos Estados Unidos, ver Flack (1951) e Walsh (1982).

24 A prática de cirurgias ginecológicas em mulheres internadas em asilos para doentes mentais foi analisada por Mitchinson (1985).

25 O Dr. Spencer Wells foi um dos mais famosos cirurgiões da Inglaterra e um praticante da ovariotomia com o objetivo de tratar exclusivamente de problemas ovarianos. A Dra. Eizabeth Blackwell foi a primeira médica formada nos Estados Unidos e uma defensora da entrada de mulheres na carreira médica. Fundou e organizou a primeira instituição hospitalar com uma equipe médica composta só por mulheres, o New York Infirmary for Indigent Women and Children, e também foi professora de ginecologia na London School of Medicine for Women entre 1875 e 1907. Sobre suas críticas à prática ginecológica pelos médicos, ver Morantz-Sanchez (1985) e Wood (1973). 


\section{A obstetrícía e a Ginecología no Brasil}

No Museu da Academia Nacional de Medicina localizado no Rio de Janeiro e no hall do Salão da Congregação do Memorial da Faculdade de Medicina da Bahia existem duas reproduções de um tema que a partir do final do século XIX ganhou significativa expressão: trata-se da imagem heróica e salvadora do médico moderno. As representações em questão são, respectivamente, uma escultura em bronze intitulada "A luta do médico contra a morte", de autor desconhecido, e um desenho colorido escolhido para ser a ilustração de um quadro de formandos da Faculdade de Medicina da Bahia. Em ambas há três figuras. Dominando a cena, está o médico vestido com um jaleco, em pé, com uma das mãos afastando a representação da morte na figura do esqueleto, que, insidiosamente, agarra-se ao corpo nu de uma mulher jovem, semidesfalecida, mas com forças ainda para procurar a proteção do médico que a ampara com a outra mão.

Esse conjunto de grande expressividade plástica foi bastante divulgado nas primeiras décadas do século XX, principalmente na forma de esculturas de pequenas dimensões, usadas como peças decorativas nos consultórios médicos ou, como preferiram os jovens médicos baianos, para compor um quadro de formatura. Este uso é ainda mais significativo, tendo em vista que a imagem foi escolhida para simbolizar a profissão que em breve esses médicos começariam a exercer e para a qual foram preparados pelos mestres cujas fotografias ladeiam a imagem formando um conjunto maior onde passado e presente convergem para o simbolismo central da figura.

Embora o autor e a época desta imagem nos sejam desconhecidos, cabe ressaltar os elementos simbólicos que foram escolhidos para dar sentido a ela e, assim, entender por que foi aceita e reproduzida no meio médico. 
Em primeiro lugar, a imagem opera com um topos muito bem consolidado na nossa cultura intelectual, que é a dicotomia. Tanto na forma de escultura, quanto na gravura há uma nítida polarização entre natureza e cultura, vida e morte, masculino e feminino.

A força da imagem vem da sua capacidade de integrar elementos simbólicos profundamente arraigados no imaginário coletivo com a nova representação do médico como defensor da vida e inimigo da morte sorrateira. A vida ameaçada é representada pelo corpo nu da mulher, uma antiga alegoria da Natureza transformada em objeto da ação e da proteção do médico. Como a imagem foi construída a partir das dicotomias, somente a representação do corpo feminino podia simbolizar ao mesmo tempo a Natureza, a vida ameaçada e o objeto do conhecimento médico. Assim, o resultado foi uma bem articulada representação na qual o novo e o antigo não se opõem, antes, complementam-se para criar um novo sentido e expressar uma nova visão do médico e da prática da medicina. ${ }^{1}$

Como representação, há ainda um segundo aspecto importante a ressaltar que é a relação entre o médico e a mulher. Além do simbolismo, a imagem alude a uma relação de fato entre o médico e a paciente que vinha se tornando uma realidade desde meados do século XIX, quando os médicos aproximaram-se das mulheres como especialistas em assuntos relativos à natureza feminina ou como conselheiros quanto ao casamento, à educação dos filhos e à organização da vida familiar. A transformação do médico em conselheiro familiar com autoridade para expressar suas idéias e prescrever condutas só se deu através da aliança estabelecida com a mulher, personagem central tanto para a entrada das idéias médicas e científicas no meio familiar quanto para a construção da reputação e da fama dos médicos. Dessa forma, a imagem do médico protetor da mulher também expressa o crescente interesse médico-científico pela natureza feminina e as doenças de mulheres, interesse este que resultou na constituição de especialidades médicas voltadas para a especificidade do sexo feminino: a obstetrícia e a ginecologia.

O tema do médico protetor da mulher era, portanto, bastante familiar para os doutorandos baianos e adequado para representar sua futura profissão. Além disso, não se pode subestimar a reputação de alguns médicos obstetras e ginecologistas que foram mestres nas faculdades mais antigas de medicina do Brasil, contribuindo para a divulgação das duas especialidades e para a formação de vários médicos parteiros e ginecologistas. 
Apesar de o ensino e a prática da obstetrícia e da ginecologia terem sido muito precários até a década de 1870, as duas especialidades tiveram seus defensores na figura de alguns dos mais famosos médicos de Salvador e do Rio de Janeiro, responsáveis pela organização destas especialidades e pela produção de um conhecimento que atendesse às necessidades impostas pelas condições culturais e materiais em que exerciam a medicina. Informados das novidades oriundas dos principais centros europeus, os obstetras e ginecologistas brasileiros procuraram constituir uma medicina da mulher sintonizada com as teorias e a tecnologia disponível, bem como produziram seus próprios conhecimentos a partir da experiência obtida na clínica particular ou nos hospitais. Não seria improvável que os jovens doutorandos vissem no médico da imagem citada a representação de muitos dos antigos mestres que defendiam o ensino da obstetrícia e da ginecologia porque, por suas características físicas, mentais e morais, a mulher era, para eles, uma criatura que merecia atenção privilegiada do médico, o único que realmente conhecia os mistérios de sua intrincada natureza.

A medicina da mulher teve seus defensores no Brasil, apesar das dificuldades materiais e institucionais, vindo a ser, no início do século XX, um campo da medicina reconhecido tanto pela categoria quanto pela clientela, que começava a procurar os serviços de obstetras e ginecologistas com maior freqüência. Com o ensino voltado para a prática e o consequente surgimento de espaços hospitalares específicos para o exercício da clínica e da cirurgia obstétrico-ginecológica, bem como de espaços institucionais para o intercâmbio de idéias - como foram as associações, os congressos de especialistas e as publicações médicas, que contavam com nomes de expressão não só na área médica e científica, mas também na política -, a obstetrícia e a ginecologia no Brasil deixaram de ser áreas de improvisação e de conhecimentos puramente teóricos. Embora as idéias sobre a mulher fossem divulgadas amplamente em outras áreas, como a higiene, a medicina legal e a psiquiatria, foram a obstetrícia e a ginecologia as duas especialidades autorizadas a falar sobre a mulher, a fornecer dados, a formular teorias e a estabelecer verdades sobre seu objeto.

A produção dos saberes sobre o corpo feminino pelos obstetras e ginecologistas brasileiros constitui uma ampla documentação através da qual é possível acompanhar a institucionalização do saber e as principais motivações dos médicos ao defender uma medicina voltada para a mulher no exercício de suas funções reprodutivas, já que estas eram a base natural 
e biológica de suas funções sociais. A produção dos saberes da medicina da mulher fornece evidências dos principais procedimentos por meio dos quais reduziram-se a subjetividade e as diferenças das mulheres a um conjunto de sintomas pré-fixados pelo saber médico; da transformação das mulheres em objetos de análise devido à determinação do aparelho reprodutivo sobre suas vidas e, por fim, da construção de uma representação naturalizada da mulher, que ora a qualifica como mãe e esposa, o lado positivo do seu destino natural, ora a desqualifica como a mulher doente, o lado negativo de uma natureza limítrofe entre a fisiologia e a patologia.

Tal qual o médico da imagem do quadro dos doutorandos baianos, nossos obstetras e ginecologistas pensavam sinceramente estar defendendo a mulher não só dos perigos e brutalidades, mas de si mesma, de sua própria natureza instável, sujeita a crises periódicas, objeto da atenção e do saber médico, exercendo, assim, um papel político ao equacionar o bom desempenho do corpo feminino a questões mais amplas como a boa formação do povo e da raça brasileira.

\section{O Ensino da Obstetrícia e da Ginecologia no Brasil}

As origens do ensino da obstetrícia estão ligadas às condições que propiciaram a criação do ensino médico no Brasil no início do século XIX. Contudo, a rigor, o ensino das disciplinas separadas só ocorreu no final do século, na década de 1880, prevalecendo, até então, unicamente o ensino da arte obstétrica, que englobava situações como a gravidez, o parto, o puerpério, as doenças dos recém-nascidos e algumas doenças ginecológicas, seguindo a mesma orientação dos centros europeus, que até meados do século não haviam separado as duas especialidades.

Oficialmente, o ensino médico no Brasil começou com a criação da Escola de Cirurgia na Bahia em 1808, como parte das ações empreendidas por D. João VI ao transferir-se com sua corte, dando início a uma série de alterações administrativas, econômicas e culturais que mudaram as feições da distante colônia. Entre tantas carências, a falta de médicos para atender às populações era um problema concreto que gerou muitas solicitações, algumas datadas do século XVII, enviadas a Portugal a fim de prover as localidades de médicos e cirurgiões. No entanto, durante todo o período colonial, as populações sofreram com a falta de médicos, contando somente com a prática da medicina popular, que concorria com os poucos esculápios habilitados e disponíveis. ${ }^{2}$ 
Se as dificuldades eram tamanhas no que diz respeito ao atendimento médico, não houve nenhuma possibilidade de formação de físicos e cirurgiões na colônia. Todo o ensino médico era centralizado em Portugal, bem como a fiscalização e a emissão de licenças para o exercício da medicina ou para a manipulação de remédios e drogas por parte dos boticários. Os interessados nas artes médicas e farmacêuticas deviam estudar por conta própria e provar seus conhecimentos junto às autoridades reais a fim a exercer sua profissão, ou então contar com a fortuna de suas famílias para realizar estudos de medicina em Coimbra. Mesmo assim, não havia muito interesse por parte dos médicos e cirurgiões formados em vir para o Brasil, devido às condições de trabalho pouco atrativas e à baixa remuneração oferecida pelas autoridades coloniais.

Há que se relevar também o acanhado ambiente cultural da colônia, nada propício ao desenvolvimento de sociedades ou academias científicas ou até mesmo de salões literários, como se deu na Europa entre os séculos XVII e XVIII. ${ }^{3}$ Algumas tentativas de dinamizar o meio cultural ocorreram durante todo o século XVIII, embora não se levasse a frente algum projeto, nem se conseguisse estabelecer um ambiente intelectual duradouro. Entre estas tentativas estão as diversas academias de cultivo às letras fundadas no Rio de Janeiro e na Bahia, como a Academia Brasílica dos Esquecidos e a Academia dos Seletos, a primeira de 1724 e a segunda de 1752, cuja duração não passou de um ano. Talvez a experiência mais duradoura tenha sido patrocinada pelo governo colonial, quando o vice-rei D. Luiz de Almeida de Mello e Silva, criou a Academia de Ciência e História Natural em 1772, com o objetivo de desenvolver estudos e propiciar discussões sobre assuntos como física, química, história natural, agricultura e também as artes médicocirúrgicas e farmacêuticas. Esta academia durou até 1779, não havendo registros posteriores sobre outro espaço do gênero. ${ }^{4}$

Apesar dos esforços das elites intelectuais, a efetivação de um meio cultural mais dinâmico e voltado para as necessidades do país foi sistematicamente barrada pelas objeções das autoridades da metrópole, que não viam com bons olhos uma certa autonomia intelectual na colônia, mesmo que fosse mediante a criação de um curso para instruir cirurgiões em lições básicas de anatomia.

Tal quadro só começou a ser alterado, portanto, quando D. João VI transferiu-se para o Brasil. Atendendo sugestões de seu cirurgião-mor, José Correia Picanço, o monarca ordenou a organização da primeira 
instituição de ensino médico-cirúrgico na Bahia e alguns meses mais tarde no Rio de Janeiro. Segundo informações do Dr. Moreira de Azevedo (1867), Picanço era natural de Pernambuco, tendo estudado cirurgia em Lisboa e Paris, vindo a tornar-se professor de anatomia e cirurgia na Universidade de Coimbra, primeiro cirurgião da casa real e cirurgião-mor do reino. Ele foi incumbido de elaborar o regimento da escola e contratar mestres que deveriam ensinar anatomia, cirurgia e a arte obstétrica. Azevedo explica que o curso de cirurgia se fazia necessário para instruir cirurgiões que tinham parcos conhecimentos de anatomia, fisiologia e medicina prática, condenando o estado em que tal prática se encontrava na colônia:

De feito mui limitado deviam ser os conhecimentos dos antigos cirurgiões e médicos que não cursavam aulas e só praticavam nos hospitais, o que não podia ser profícuo nem vantajoso, não tendo eles ciência para apreciarem convenientemente os fatos e observarem os fenômenos, sintomas e alterações mórbidas; não passavam de simples enfermeiros e cirurgiões empíricos e muitos, sem haverem percorrido as salas de enfermarias, apresentando atestados graciosos ao cirurgião-mor, obtinham, após um exame ligeiro e irregular, carta para exercitar a arte da cirurgia. (Azevedo, 1867: 400-401)

Embora a arte obstétrica estivesse contemplada no esboço inicial da Escola de Cirurgia, não há registros a respeito do seu ensino na Bahia até 1818, quando o plano de estudos da Escola foi reformulado. Já no Rio de Janeiro, foi nomeado para ser professor da matéria o Dr. Joaquim da Rocha Mazarém, cirurgião-parteiro que, posteriormente, tornou-se catedrático de obstetrícia em Lisboa, tendo publicado livros sobre o assunto que demonstram sua orientação para o exercício da especialidade baseado na observação metódica e numa atitude científica. Segundo a pesquisadora portuguesa Margarida Ribeiro (1990), Mazarém foi o primeiro obstetra português a produzir obras de caráter científico distintas das obras anteriores da medicina tradicional e empírica.

$\mathrm{Na}$ primeira fase da implantação do ensino médico o aprendizado das técnicas cirúrgicas e da arte obstétrica ocorria no último ano do curso. Segundo Moreira de Azevedo (1867), o ensino da cirurgia e da obstetrícia foi prejudicado porque, tanto Correia Picanço quanto outros cirurgiões portugueses fizeram oposição às duas escolas, não permitindo o funcionamento normal do quarto e quinto anos, impedindo que se conferissem os diplomas para os médicos e cirurgiões no Brasil. Além dessas dificuldades, mesmo contando com professores de reconhecida competência, 
como Mazarém, o ensino da obstetrícia era bastante precário tendo em vista a falta de instalações adequadas, livros e material didático, o que tornava as aulas uma monocórdia leitura de tratados e compêndios, não tendo os alunos nenhum aprendizado prático, pois as aulas, que deveriam funcionar nos hospitais da Santa Casa de Misericórdia de Salvador e do Rio de Janeiro, não ocorreram devido à ausência de enfermarias para grávidas e puérperas.

Na sua pesquisa histórica sobre a obstetrícia no Brasil, o Dr. Fernando Magalhães (1922b) comenta que no Rio de Janeiro o ensino da arte obstétrica vinha ocorrendo, mesmo com deficiências, desde a nomeação de Mazarém, sendo que alguns professores tentaram iniciar mudanças, procurando tornar o curso mais adequado ao ensino da ciência obstétrica produzido na França e na Inglaterra, como se pode perceber pela solicitação do Dr. Manoel da Silveira Rodrigues, professor de partos em 1823, formado em Edimburgo e com experiência em hospitais londrinos e parisienses, pedindo ao governo que adquirisse para o curso "um fórceps de Levret, um compasso de Baudelocque, uma alavanca, dois ganchos, um fura crânios, um esqueleto e um manequim com feto" (Magalhães, 1922b: 63).

A ausência desses instrumentos, já bastante comuns na prática da obstetrícia, e do material didático, 14 anos após a criação das escolas, é bastante reveladora das precárias condições do ensino da obstetrícia e do descompasso entre a prática da medicina da mulher no Brasil e aquela exercida nos centros europeus. Este quadro foi alterado a partir do último quartel do século XIX, quando os médicos obstetras e ginecologistas brasileiros começaram a desenvolver instrumentos e técnicas cirúrgicas próprias, como é o caso dos doutores Werneck de Almeida e Fernando Magalhães.

Apesar da constatação da importância da disciplina, as condições de ensino não se alteraram em relação à época das escolas cirúrgicas. Todos os autores contemporâneos, bem como os memorialistas que analisaram o período anterior à década de 1870, são unânimes em apontar as fragilidades de um ensino de obstetrícia eminentemente teórico. As memórias históricas da Faculdade de Medicina da Bahia trazem algumas informações sobre as dificuldades enfrentadas pelos professores e alunos de forma geral e em especial no ensino da obstetrícia; conforme o Dr. Rodrigues Silva: "A prática de partos consistia em manobras exercidas sobre um manequim ridículo, que mais provocava risos do que prestava-se a aprendizagem séria" (Rodrigues Silva apud Adeodato Filho, 1967: 26). 
De acordo com os críticos, aquele estado de coisas permitia que os alunos saíssem do curso sabendo fazer apenas partos teóricos, isso em uma época em que, na Europa, os métodos clínicos já estavam sendo colocados em prática nos hospitais e no atendimento privado, conforme vimos no segundo capítulo.

Alguma esperança de transformação foi alentada com a Reforma da Instrução Superior do Império, de 1854, normatizando o funcionamento das cátedras, exigindo maior empenho dos professores e ampliando o currículo, mas, no que diz respeito à obstetrícia, as coisas não mudavam. Segundo testemunhos da época, permaneciam a mesma cadeira de partos sem o ensino prático, embora, no exercício da medicina, os professores das duas faculdades começassem a colocar em prática as mais recentes inovações da obstetrícia científica, como o uso do clorofórmio nos partos, a aplicação de diferentes tipos de fórceps e a realização de operações obstétricas, como a versão e a craniotomia. Na verdade, o que se percebe pela leitura das críticas ao ensino é que havia uma experiência clínica razoavelmente bem conduzida pelos médicos mais renomados da época, enquanto a formação dos estudantes de medicina continuava fundamentada na leitura dos tratados franceses de obstetrícia.

Autores como Fernando Magalhães (1922b) e José Adeodato Filho (1967), que escreveram livros de abordagem histórica da obstetrícia no Brasil, concordam que grande parte do problema teria sido contornado se houvesse maior empenho do Governo Imperial com a instrução de nível superior, doando verbas para a construção de laboratórios e para a aquisição de novos livros. Mas, havia também, segundo estes autores, impedimentos colocados pelos administradores dos hospitais mantidos pelas Santas Casas de Salvador e do Rio de Janeiro. Desde a época da criação das Escolas Cirúrgicas estava previsto que os professores deviam levar seus alunos para aulas práticas junto aos doentes internados nos hospitais de caridade. Estes apresentavam condições muito precárias para o atendimento dos doentes, a começar pelas péssimas instalações, a sujeira e a superlotação. Os hospitais de caridade eram a única opção para as pessoas pobres ou cidadãos de classes inferiores, como os definiu Russell-Wood (1981), homens e mulheres negros e indivíduos brancos sem posses, estrangeiros, marinheiros e soldados.

Com todos os seus problemas, os hospitais de caridade tentavam socorrer os desassistidos, mesmo que fosse para ampará-los na hora da morte, já que não havia muitos meios para debelar as doenças. Os hospitais 
eram divididos em algumas enfermarias, geralmente muito pobres e pouco asseadas, tendo alguns toscos catres, poucos colchões ou somente esteiras, locais estes onde deviam ser ministradas as aulas práticas. Havia uma enfermaria para as mulheres que não era para atendimento obstétrico especificamente, mas todos os tipos de doenças, como a febre amarela, a tuberculose, as doenças venéreas e gastrointestinais e os problemas de pele. Em meados do século XIX, as mulheres brasileiras não procuravam os hospitais para dar à luz, tanto que em uma análise dos livros de registros de entradas e saídas de pacientes do Hospital da Santa Casas de Salvador, entre 1852 e 1853, encontram-se apenas três casos relacionados à obstetrícia e somente um parto, realizado na liberta Guilhermina, de 20 anos. ${ }^{5}$

A situação era um pouco diferente no Rio de Janeiro, onde desde 1847 funcionava no Hospital de Caridade da Santa Casa uma enfermaria de partos para atender mulheres pobres, ficando sob os cuidados das irmãs de caridade. Embora fosse adequada para o ensino médico, os provedores e as irmãs da Santa Casa puseram forte resistência à entrada dos alunos na enfermaria. O impasse gerado pela administração do hospital parece ter sido motivado por algum incidente sério ocorrido logo após a Reforma de 1854 envolvendo os estudantes de medicina e o mordomo da Santa Casa, que teria levado o Governo Imperial a intervir no caso. Sem entrar em detalhes sobre o que teria acontecido, Fernando Magalhães (1922b) considera que o fato desencadeou a resolução do hospital em não consentir a existência de uma clínica obstétrica, muito menos com a franquia dos alunos à enfermaria de partos.

A resistência dos provedores e a exposição de seus motivos estão registrados na intensa correspondência entre eles, os diretores da Faculdade de Medicina do Rio de Janeiro e o ministro de Estado. Há vários ofícios dos diretores da faculdade pedindo a intervenção do governo para que se fizesse cumprir o Decreto 1.764 , de 1856, que previa o ensino clínico nas enfermarias da Santa Casa, não só de obstetrícia, mas de anatomia, fisiologia e clínica médica, repetidamente negado pelos provedores. Em um desses ofícios, o provedor expõe ao ministro os motivos pelos quais ele e seus antecessores negaram os pedidos da Faculdade de Medicina do Rio de Janeiro:

Uma longa e dolorosa experiência leva a Santa Casa a pensar que se franquearem-se enfermarias de mulheres aos alunos de clínica cirúrgica como se lhes franqueam as dos homens, hão de provir à disciplina e à moralidade do estabelecimento males incalculáveis e esse exemplo, apoiado nos fatos, 
tem sido e será sempre a causa principal de não aderir a Provedoria, apesar dos seus bons desejos, às solicitações anuais dos diferentes diretores da Faculdade de Medicina da Corte. Acresce, Excelentíssimo Senhor, que na parte do Hospital destinada às mulheres, não há os cômodos precisos para o ensino da clínica.(...) Quando houver hospitais por conta do governo que se ponham à disposição do estudo das aulas de clínica, não sei se o provedor permitirá que se franqueem igualmente aos mancebos que estudarem cirurgia as enfermarias de homens como de mulheres. A Santa Casa de Misericórdia da Corte não pode admitir no seu hospital semelhante igualdade e espera que V. Exa. faça justiça às suas intenções. ${ }^{6}$

Embora o ofício mencione problemas que teriam ocorrido com a entrada dos alunos na enfermaria de mulheres, percebe-se que a resistência estava mais relacionada à necessidade em se manter a segregação sexual, questão que não pode ser subestimada para os padrões morais da época. No Hospital de Caridade de Salvador também havia a mesma preocupação, embora os provedores permitissem as aulas nas enfermarias de mulheres.

A forte noção de que as esferas de atuação de ambos os sexos deviam ser rigidamente distintas tinha, entre seus fundamentos, um sólido componente moral, pois temia-se que a ordem - fosse religiosa ou, como é o caso, hospitalar - pudesse ser abalada caso homens e mulheres convivessem no mesmo espaço sem uma estrita vigilância. Não se pode subestimar também o fato de que pesavam sobre o parto e as doenças femininas um estigma social que só começou a ser enfrentado pelos médicos quando a questão foi tratada no âmbito da necessidade do ensino prático para uma melhor e mais completa formação profissional.

Outro aspecto importante desta polêmica que por tanto tempo obstou o ensino prático da obstetrícia e da ginecologia no Rio de Janeiro foi a reação de autoridades civis e religiosas à criação de estabelecimentos hospitalares específicos para o atendimento obstétrico. Autores como Gélis (1977), Laget (1977) e Shorter (1984) comentam que esta reação às maternidades também ocorreu na Europa porque as primeiras enfermarias de partos criadas nos mais antigos hospitais eram verdadeiras casas de morte, sendo mal afamadas até meados do século XIX. No Brasil, esta reação a uma simples enfermaria de partos deve ser entendida como expressão dos preconceitos das autoridades e também das irmãs de caridade contra as mães solteiras, na sua maioria mulheres negras ou brancas pobres. Temia-se que um estabelecimento com esta finalidade incentivasse a maternidade fora do casamento. Ao tratar desta questão, Souza (1998) 
refere-se a um documento no qual o diretor da faculdade atribuía à madre superiora da Santa Casa a crença de que a enfermaria seria freqüentada por prostitutas. Provavelmente, o diretor não estava exagerando na sua denúncia, pois em uma ata da Santa Casa há referência aos serviços que a enfermaria de partos prestava às mulheres pobres e casadas. ${ }^{7}$

A questão do ensino prático da obstetrícia só começou a encontrar solução após a Reforma Sabóia, de 1882, que ampliou o currículo dos cursos de medicina, criando novas disciplinas com finalidade clínica, entre elas a clínica obstétrica e ginecológica. A antiga Cadeira de Partos foi substituída pela Cadeira de Obstetrícia, de caráter mais teórico, enquanto a nova Cadeira de Clínica deveria propiciar aos alunos a experiência junto às grávidas e puérperas, bem como às questões relativas às doenças ginecológicas. ${ }^{8}$

Cientes da necessidade do ensino prático e amparados pela legislação, o autor da reforma e diretor da faculdade, Dr. Sabóia; famoso professor de clínica médica, Dr. Torres Homem; o professor de medicina legal, Dr. Agostinho de Souza Lima; e o professor de anatomia, Dr. José Pereira Guimarães, assinaram o ofício enviado à Santa Casa, acordando os termos do funcionamento das clínicas no hospital. Após rebater as críticas quanto à presença dos alunos nas enfermarias, defenderam a necessidade da clínica obstétrica em especial, dizendo que as parturientes não ficariam expostas aos alunos, com exceção daqueles que estivessem sob a orientação do professor ou de seu assistente. Por fim, apelavam ao bom senso dos administradores, defendendo o ensino da obstetrícia:

Se até hoje estávamos privados do ensino destas clínicas, se até agora, para exercer conscienciosamente a arte de partos era preciso que um médico brasileiro, rico ou pobre, fosse à Europa, certamente não dávamos prova de bom senso; e não tínhamos motivo senão para nos envergonharmos. E quantas vítimas não se contaram em nosso imenso país, quantos filhos não se acharam na orfandade e na miséria por terem perdido aquele que lhes deu o ser, nas mãos de médicos ignorantes ou que saindo de nossas faculdades foram chamados para prestarem os socorros da arte a uma parturiente, quando eles aqui nunca assistiram a um parto. ${ }^{9}$

Mesmo com esta reforma, a clínica obstétrica e ginecológica não funcionou imediatamente, sendo utilizada para este fim a Casa de Saúde Nossa Senhora da Ajuda. Há referências quanto às condições da enfermaria de partos da Santa Casa no final da década de 1880, quando o Dr. Érico Coelho, professor concursado para a cadeira, comentou que as instalações 
eram precárias, funcionando numa "imunda enfermaria conhecida pela alcunha de maternidade da Faculdade" (Magalhães, 1922b: 86).

Já em Salvador os alunos não precisaram esperar tanto tempo para começar as aulas práticas de obstetrícia. Embora pudessem freqüentar as enfermarias do Hospital da Santa Casa, pouco lá havia para se observar, pois, como vimos, o hospital não contava com uma enfermaria de partos. Foi somente em 1875 que as coisas começaram a mudar, quando foi transferido da Cadeira de Anatomia para a Cadeira de Partos o Dr. Adriano Alves de Lima Gordilho, futuro Barão de Itapoan.

Fernando Magalhães (1922b) comenta que o fato de ter sido necessária uma transferência e não um concurso demonstra como os professores anteriores a Gordilho não haviam conseguido fazer discípulos capazes de assumir uma cátedra. Acrescente-se ao comentário de Magalhães que, possivelmente, tal situação se devesse ao desprestígio da obstetrícia entre os próprios médicos, algo que foi recorrentemente criticado pelos seus defensores como exemplo da miopia intelectual de seus colegas e falta de sensibilidade para com as mulheres grávidas e parturientes.

Magalhães (1922b) e José Adeodato Filho (1967) não economizaram elogios ao Barão de Itapoan. Cirurgião formado na Europa e com experiência na arte obstétrica tinha grande clientela em Salvador e muito prestígio. Logo que assumiu a cátedra, o provedor da Santa Casa ofereceu-lhe um espaço no hospital para a clínica obstétrica, iniciando-se o ensino prático. Pelo que informa Magalhães, o médico baiano era tão famoso em Salvador quanto reconhecido por seus pares na Corte, onde estavam os médicos parteiros mais respeitados. Apesar da fama e do reconhecimento do Barão, houve reações da população soteropolitana à enfermaria de partos, bem como das próprias parturientes, que receavam permanecer no hospital. Os médicos atribuíram esta reação à precariedade das instalações, ao instrumental antigo e à resistência das poucas mulheres que procuravam o atendimento para servir de objeto às funções letivas.

É interessante notar que não era só a péssima fama do hospital da Santa Casa que afastava as mulheres, mas a situação de expor-se aos alunos nas aulas de clínica obstétrica. Este comportamento foi observado também nos hospitais de mulheres e maternidades européias e norteamericanas, nas quais a maior parte das pacientes era de mulheres pobres, das classes trabalhadoras e imigrantes que não se submeteram facilmente aos protocolos hospitalares nem aceitaram sem resistências a transformação 
de seus partos em casos descritos pelos professores e observados pelos estudantes. Entretanto, parece que a aceitação das mulheres em dar à luz nos hospitais de Salvador e do Rio de Janeiro esteve relacionada à melhoria das instalações e do atendimento, bem como à divulgação dos serviços obstétricos prestados pelos médicos e parteiras diplomadas que passaram a integrar as equipes obstétricas dos hospitais.

Esse parece ter sido o motivo que levou as mulheres a procurar o novo hospital construído e inaugurado em 1883 em Salvador. O Hospital foi projetado segundo as novas orientações arquitetônicas e científicas que estavam em voga na Europa desde o final do século XVIII, visando a transformar os hospitais em 'máquina de curar' e não casas de morte. ${ }^{10}$ Com 600 leitos distribuídos em várias enfermarias bem ventiladas e com corredores amplos, o hospital não lembrava em nada o velho Hospital de Caridade. Nele, logo começaram a funcionar as clínicas obstétricas e ginecológicas sob a direção do catedrático Dr. Climério de Oliveira, que substituiu o Barão de Itapoan. Em uma carta citada por Adeodato Filho (1967), o professor Climério comenta que o curso de partos estava se desenvolvendo satisfatoriamente sendo bem freqüentado pelos alunos, e que o número de mulheres atendidas estava se ampliando.

Assim, somente no final do século XIX os estudantes de medicina começaram a ter um ensino de obstetrícia voltado para a clínica, aprendendo a realizar exames, a reconhecer as posições e apresentações do feto, a utilizar o instrumental obstétrico e a fazer cirurgias. Mesmo não sendo o ideal, o sistema de enfermarias proporcionou aos estudantes as condições para observar o corpo feminino e saber agir tanto nos partos naturais quanto nas distocias. Somente no século XX as faculdades de medicina passaram a ter um espaço adequado ao ensino das clínicas obstétrica e ginecológica, quando começaram a ser construídas as primeiras maternidades no Brasil. Até então, o ensino teórico foi mais privilegiado e com ele difunfiu-se, entre os estudantes e futuros médicos, boa parte do conhecimento das duas especialidades produzido na Europa e propagado pelos alunos nas suas teses de conclusão de curso.

Apesar de todas as dificuldades enfrentadas desde a criação das faculdades de medicina, o nível dos conhecimentos teóricos adquiridos não era muito defasado em relação ao que se produzia nos principais centros do ensino médico fora do Brasil. Embora as queixas dos memorialistas fossem constantes, o acervo das bibliotecas das duas faculdades foi 
melhorando após as reformas de 1854 e 1882, contando com alguns dos títulos mais importantes de todos os campos da medicina e das ciências biológicas publicados no século XIX. ${ }^{11}$

As teses médicas são, portanto, um conjunto de documentos que informam sobre as principais doutrinas e conceitos divulgados pelos professores, livros e periódicos disponíveis. Fornecem também um quadro razoável das idéias e representações sobre a mulher, já que, conforme vimos, até o final do século XIX os estudantes pouco ou nada conheciam do corpo feminino, embora este desconhecimento não os tenha impedido de produzir um saber sobre a mulher e o seu corpo, mesmo que fosse, na verdade, uma reprodução do que liam ou ouviam durante os cursos e não uma reflexão fundada na observação.

Era bastante comum entre os autores das teses uma citação de La Bruyère "Muito se deve exigir do indivíduo que por lucro e interesse lança mão da pena para se fazer autor, porém aquele que vai cumprir um dever, de que não pode eximir, é digno de complacência pelas suas faltas". Com este pedido antecipado de benevolência à banca examinadora e aos futuros leitores, muitos doutorandos expressaram seu desagrado com a obrigatoriedade de escrever a tese para obter o grau de doutor em medicina. Desde a criação das faculdades de medicina em 1832 os estudantes tinham de apresentar uma tese versando sobre um assunto médico de livre escolha que poderia ser escrito em português ou latim, cuja impressão era custeada pelo autor. Segundo o estudo que Marcos Augusto Pessoa Ribeiro (1997) realizou a respeito da Faculdade de Medicina da Bahia, a obrigatoriedade das teses aliada a outros problemas de formação e de relacionamento entre alunos e professores acabou por levar a um processo de decadência das mesmas, apontado e criticado pelos memorialistas.

Tendo em vista todas as dificuldades materiais e culturais da época, as congregações das duas faculdades idealizaram as teses como uma forma de avaliar o nível dos conhecimentos adquiridos durante o curso e também para criar um ambiente científico, semelhante ao que ocorria na França, onde os alunos também tinham de defender teses de conclusão de curso. Contudo, as coisas não correram exatamente como previam os idealizadores e, já a partir de meados do século XIX, o nível das teses deixava muito a desejar. Ainda de acordo com Ribeiro (1997), a decadência se deu pela falta de experiência dos alunos, que não conseguiam desenvolver trabalhos originais, e pela negligência dos professores, que acabaram por facilitar as 
defesas não sendo criteriosos na atribuição dos méritos e distinções. Tal situação é visível nas teses, sendo a maioria um conjunto de citações sem envolvimento crítico ou pelo menos posicionamento dos autores.

No entanto, nem todas as teses eram ruins. Percebe-se mesmo o esforço sincero de muito doutorandos em desenvolver seus temas com uma certa originalidade, até mesmo tomando cuidados como apresentar bibliografia completa e observações clínicas, ou então emitir opiniões sustentadas em teorias e na experiência adquirida junto aos professores nas enfermarias de mulheres ou de partos. Alguns até se esmeraram no estilo, produzindo textos de cunho mais literário do que científico, embora este pendor pelas letras não fosse muito comum. Há um certo padrão na forma de apresentação, pelo menos nas teses mais antigas, começando pelas longas dedicatórias e pelos agradecimentos. Como observou Dinorah Castro (1973), as dedicatórias expressavam sentimentos de parentesco e amizade, sendo escritas numa linguagem rebuscada e lírica, bem ao gosto da época. Um bom exemplo do cuidado com as dedicatórias pode ser visto na tese do Dr. Miguel Couto dos Santos Junior (1878) que, em oito páginas, cita 59 pessoas a quem prestou seus agradecimentos, extensivos aos primos, primas, sobrinhos e familiares dos homenageados.

Em seguida às dedicatórias, geralmente havia uma breve introdução e a tese propriamente dita, geralmente dividida em dois ou três capítulos. Por fim, o autor apresentava uma série de proposições relacionando o tema a cada uma das cadeiras cursadas. O conteúdo das teses é muito desigual, sendo algumas extremamente vagas e repetitivas, quando não meras reproduções dos autores que serviram como referência. Há alguns que se mostraram preocupados com o conteúdo de suas teses, não tanto para o caráter científico da mesma, mas para que ela tivesse utilidade para os futuros leitores. Poucos, no entanto, tiveram a ousadia e a coragem de expressar suas opiniões como o Dr. Pedro Araújo (1883: 3) que usou como epígrafe uma frase própria: "Esta these foi escripta por mim: pudessem todos os médicos passados e futuros escrever o mesmo no frontispício de que chamam sua these". Araújo tocava num ponto sensível da obrigatoriedade das teses que era a falta de originalidade e de posicionamento dos autores, o que o levou a defender o caráter facultativo das mesmas.

Teses como a do Dr. Araújo são exceções, pois ele teve o trabalho de fazer uma longa lista dos livros que consultou, assinalando-os para explicar se eram ou não reprodução total ou parcial de outras obras. Assim, preocupou-se em mostrar seu método de pesquisa e seus critérios: 
Apresentei esta lista de livros para que cada um possa verificar com toda cautela e paciência as fontes onde bebi. Creio que depois reconhecerá o meu esforço e a lealdade com que procedi. Não tive em mira outro fim, nos melhores livros encontrei parágrafos inteiros extraídos de outros. (1883: 3)

Apesar dos problemas apontados pelos memorialistas e mesmo por doutorandos como Araújo, algumas teses conseguiram tratar satisfatoriamente dos temas propostos e são estas que nos forneceram elementos para conhecer o nível das informações obstétricas e ginecológicas no Brasil do século passado, bem como as idéias que circulavam no meio acadêmico a respeito da mulher. ${ }^{12}$

Tendo em vista a diversidade de temas e o grande número de teses produzidas, adotou-se o critério cronobiológico com o qual os médicos dividiram as fases da vida das mulheres. Da puberdade à menopausa temse, portanto, o arco da existência feminina marcada pela função reprodutiva. Descrita através dos fenômenos fisiopatológicos, esta existência parece ter estimulado os jovens doutorandos a escrever e a endossar a frase de Moreau de la Sarthe também muito usada como epígrafe: "L'époque la plus intéressante de la vie de la femme est celle de ses souffranges et de ses dangers" (a época mais interessante da vida da mulher é aquela de seus sofrimentos e perigos).

Esta época 'interessante' estimulou pesquisas e investigações, resultando na produção de um saber sobre o corpo feminino que também instigou os jovens doutores brasileiros que escreveram teses sobre a mulher movidos pelo interesse que sua existência particular suscitava:

Nascida fraca e sensível, destinada pela natureza a nos dar a existência e a no-la conservar por cuidados ternos e vigilantes, a mulher, essa companheira fiel do homem, merece o mais vivo interesse e apresenta um vasto campo de meditações aos médicos e aos filósofos. Que objeto mais digno de nossa atenção do que a série de mudanças físicas, morais e psicológicas que acompanham a mulher em todas as épocas de sua existência? (Barros, 1840: 3)

\section{Um Corpo em Mutação: o tempo dos mênstruos}

É bastante significativo o número de teses médicas sobre a mulher produzido no século XIX, particularmente após a implantação do ensino clínico da obstetrícia e da ginecologia. Os estudantes de medicina seguiam uma orientação presente nas publicações que tinham acesso, não somente 
aquelas que apresentavam as novidades no campo da medicina, mas também publicações filosóficas, sociológicas e literárias que igualmente elegeram a mulher como seu objeto de reflexão. Sintonizados com o que estava sendo discutido nos meios científico e intelectual fora do Brasil, os estudantes de medicina também contribuíram para este grande circunlóquio a respeito da natureza feminina e de suas diferenças.

Quase todas as teses analisadas trazem uma justificativa científica sobre a escolha do tema, embora ressaltem a necessidade de estudar a mulher por se tratar de um assunto com desdobramentos sociais importantes devido ao papel desta como reprodutora da espécie e educadora dos filhos e futuros cidadãos. Há também o que se pode chamar de justificativa política de gênero, fundada na relação de objetivação entre um ser fraco e dependente - a mulher - e o sujeito do conhecimento, responsável por estabelecer um discurso verdadeiro sobre seu objeto, julgando, com isso, nada mais fazer do que exercer o papel de protetor.

Uma questão central para os autores das teses é a definição da mulher, algo que, para eles, parecia não estar muito claro. Apesar dos esforços dos médicos e cientistas, a mulher parecia escapar das definições, como expressou Pedro Araújo (1883: 7) numa passagem que resume bem as idéias de sua época:

Predestinada desde toda a eternidade para os misteriosos desígnios da Providência, a mulher não tem podido nem pode deixar de ser, em todos os tempos e em todos os países, um objeto sempre atraente sempre novo para fixar a atenção e cativar o espírito. Desde Eva, a primeira, até a última Eva, todas as comparações ter-se-ão esgotado, as mais complexas e as mais extravagantes teorias terão sido imaginadas e discutidas, e a mulher, sempre a mesma, haverá permanecido sem uma definição que satisfaça ao amante, ao poeta, ao filósofo, ao naturalista, ao fisiologista, ao médico, ao homem enfim.

É interessante observar como o autor conseguiu expressar a insatisfação que motivou a produção do saber sobre a mulher no século XIX. Embora contassem com um grande conjunto de textos dos mais diferentes campos da produção cultural, a mulher permanecia enigmática, como se toda aquela produção ainda não conseguisse alcançar um significado satisfatório, totalizante, como reclamava Araújo.

Muitas definições procuraram fixar a mulher, mas foram as explicações médico-biológicas da época as que maior impacto tiveram na construção das representações sociais. É provável que a seqüência 
apresentada por Araújo (1883) não tenha sido ocasional - do amante ao médico -, mas sim intencional, apontando para uma evolução das definições mais subjetivas para as mais objetivas. Foram os médicos que, apoiados nas pesquisas biológicas sobre a ovulação e a reprodução, construíram uma definição da mulher sustentada no seu ciclo de vida reprodutiva. Ao estabelecer as idades do corpo feminino, os médicos pensaram estar construindo uma definição materialista, fenomenológica da mulher, para a qual não houve paralelo com o homem. De acordo com o autor, naturalistas, fisiologistas e médicos acreditavam que, com uma abordagem materialista, estariam prestes a desvendar os mistérios da feminilidade. Vejamos, então, como se deu este processo investigativo analisando os conhecimentos produzidos nas teses médicas.

Embora o interesse pela mulher estivesse disseminado nas teses de higiene, psiquiatria e medicina legal, a discussão em torno das idades do corpo feminino se deu particularmente nos campos da obstetrícia e da ginecologia, afinal eram as duas especialidades com autoridade legítima para discorrer a respeito do assunto. ${ }^{13}$ Para os ginecologistas em especial, a primeira questão a ser resolvida era saber quando a mulher começava a ser diferente do homem, ou seja, quando começava a ser mulher. Essa questão pode parecer, para os dias de hoje, algo um tanto quanto bizantino, mas não o era para os médicos do século XIX. Conhecer as transformações do corpo feminino que tornavam a mulher apta para a reprodução era um importante passo não só na construção do conhecimento como também na argumentação médica sobre assuntos como a idade adequada para o casamento e a maternidade, questões que não deixam de ter sua validade nos nossos dias. ${ }^{14}$

Para os ginecologistas, a criança do sexo feminino tornava-se mulher quando se iniciava o processo acentuado de diferenciação sexual em relação ao homem, fase denominada de puberdade. Embora meninos e meninas passem igualmente por uma série de mudanças físicas e comportamentais durante a puberdade, não há menção nos livros e teses a respeito do momento em que o menino passava a ser homem. Tem-se a impressão de que somente a mulher se diferenciava, daí a necessidade de conhecer em detalhes todas as transformações que resultavam na diferença sexual feminina.

O que não se pode perder de vista é a relação explícita, neste caso, do que Afonso Romano de Sant'Anna (1984) qualificou como o poder lingüístico dos homens, ao analisar a poesia sobre o desejo masculino. 
No que se refere à medicina da mulher, essa relação de poder se instaura na assimetria existente entre uma escrita prolífica e um corpo silencioso, tal qual aparece nas imagens científicas. De acordo com a ideologia de gênero, a mulher, sendo mais fraca e menos provida de razão, não podia se representar (tanto política quanto cientificamente), necessitando, portanto, de uma voz autorizada para fazê-lo.

Observando o relato desse processo nas teses, percebe-se como a diferenciação sexual torna-se, no discurso, um processo exclusivamente feminino. Se durante a infância as diferenças entre meninos e meninas estão restritas aos órgãos sexuais, a puberdade é narrada como um momento em que o corpo feminino começa a sofrer transformações que o distinguem radicalmente. Nenhuma palavra foi mencionada, mesmo com finalidade comparativa, para as transformações nos corpos masculinos, já que estes não sofriam as mesmas determinações dos órgãos sexuais, afinal eram seres cerebrais. Somente os pervertidos e os desviantes que não se adequavam à normatização dos papéis masculinos caíam nas redes dos saberes médicos, como os homossexuais e os masturbadores. ${ }^{15}$

Foi para essas transformações, então, que os ginecologistas se voltaram. A princípio, a puberdade na mulher foi definida como uma fase de mudanças nos órgãos reprodutivos que a capacitavam para a vida reprodutiva, marcada pelo aparecimento da menstruação. Contudo, esta definição tradicional, repetida inúmeras vezes nas teses, levantava um problema de natureza legal e cultural, que era a idade do casamento. Os médicos salientavam que a capacidade reprodutiva não significava maturidade para conceber, ou seja, a puberdade não era sinônimo de nubilidade.

A respeito desse assunto os médicos não economizaram palavras. O autor mais citado e reconhecido como autoridade sobre o assunto foi Adam Raciborski, as teses que trataram da puberdade na mulher são unânimes no seu reconhecimento. Raciborski escreveu um famoso tratado sobre a menstruação em 1868, que permaneceu como referência obrigatória até o início do século XX. Foi professor da Faculdade de Medicina de Paris e publicou vários trabalhos a respeito da menstruação desde a década de 1840 , vindo a ser considerado como uma das mais respeitadas autoridades também sobre a ovulação. Na introdução do seu tratado, alerta seus colegas de profissão para uma questão de grande importância para as famílias, a idade do casamento das jovens, questão esta que os tratados de higiene não vinham abordando de maneira satisfatória, segundo o autor. Aponta 
então para as perguntas mais freqüentes que os pais das moças faziam, entre elas, a idade ideal para casá-las, se o casamento podia ocorrer antes do aparecimento da menstruação e se haveria algum estado mórbido para o qual o casamento seria uma indicação terapêutica.

Para o autor, tais questões não eram preocupantes apenas para as famílias, que deviam ser bem orientadas pelos médicos, mas também tornaram-se objetos de incessantes meditações dos economistas, moralistas e médicos:

Os primeiros vêem esta questão do ponto de vista da população e dos meios de subsistência; os moralistas levam em consideração os costumes, enquanto os médicos analisam a questão sob o ponto de vista dos interesses higiênicos e em particular sobre a constituição e o vigor dos povos. (Raciborski, 1868: 322)

Raciborski mostra-se contrário aos casamentos precoces, defendendo que a melhor idade para a mulher se casar devia ser entre os vinte e os vinte e cinco anos. Essa mudança no pensamento médico deve-se à experiência que adquiriram como médicos-parteiros, observando os efeitos danosos da gravidez em mulheres muito jovens. Para ele, as condições físicas que possibilitavam a concepção não eram suficientes:

A verdadeira maturidade, denominada nubilidade, difere da puberdade (...). As relações sexuais prematuras são perigosas tanto para a espécie humana quanto para os animais e plantas; elas não são prejudiciais só para os reprodutores, mas também para os produtos daquelas relações. (1868: 326)

O autor mostra-se bastante cauteloso quanto às outras questões. Embora não fosse um polemista, suas idéias apontavam para a necessidade de o médico conhecer cada caso particularmente, evitando teorias muito generalizantes e sem fundamento clínico, como a idéia bastante antiga de que o casamento era o melhor remédio para a histeria. O renomado médico mostra-se bastante cético também quanto aos propalados benefícios do casamento mesmo reconhecendo toda uma tradição médica que defendia tal medida. Raciborski foi um dos primeiros autores a separar os conceitos de puberdade e nubilidade, defendendo a idéia de que as mulheres deveriam, antes de se casar, ter uma certa experiência de vida e conhecer melhor o mundo e as pessoas, qualidades que ele considerava preciosas para que pudessem ser felizes no casamento. 
Suas idéias foram bem aceitas no meio acadêmico brasileiro, como se pode ver pelas citações nas teses. Alguns apenas contentaram-se em citá-lo; outros, mais críticos, como o jovem Dr. Afrânio Jorge (1905), partiram de suas idéias para condenar os legisladores brasileiros que estabeleceram a puberdade de como a idade para o casamento, fixada em 12 anos para as mulheres. Afrânio Jorge explica que os legisladores adotaram como critério o aparecimento da menstruação. Para ele, tal critério fundado em um fenômeno exclusivamente fisiológico não era adequado, pois, sendo o aparelho genital feminino tão complexo precisava de um certo tempo para completar sua formação a fim de adquirir vigor e perfeição. Mesmo que o casamento tivesse como finalidade a procriação, disse Afrânio Jorge, a mulher não era apenas uma reprodutora, mas esposa e mãe, e, para cumprir essas funções sociais, devia ter maturidade física e emocional.

Outro crítico foi Dr. Manuel Ramalho (1906), lembrando que o casamento não era uma simples armadilha, como teria dito Schopenhauer (1900), mas um importante fator de higiene e moral, base da família e da pátria. O médico cita várias estatísticas de mortalidade feminina produzidas em países europeus para reforçar sua tese contrária ao casamento de mulheres muito jovens. Além dos inconvenientes para a saúde das mulheres, Ramalho lembra que as uniões precoces eram, em última instância, inconvenientes para a raça, defendendo a necessidade de exames médicos para os nubentes e de aconselhamento às famílias:

Felizmente o tempo do inconsciente já se vai passando, a luz da ciência já se vai difundindo pelos desvãos da família, a educação pudibunda e mística já vai cedendo lugar à racional prática.(...) Ao lado da inclinação natural que arrasta os dois seres que se completam, a fisiologia, ou antes a higiene, deveria dar seu veredito sobre se desta união a família será enriquecida com uma progênie forte e sã ou se, pelo contrário, será aumentada de mais um tuberculoso, epiléptico ou histérico. (Ramalho, 1906: 34)

Com essas idéias, Ramalho antecipava algumas teses defendidas posteriormente pela doutrinação eugenista que teve muitos seguidores no Brasil. Mas o que é mais importante ressaltar no discurso de Ramalho é a defesa de um papel mais ativo do médico em assuntos que até então eram exclusivamente da esfera familiar. O discurso médico sobre a idade ideal para a mulher se casar é mais uma evidência do lento e progressivo processo de intervenção dos médicos em vários espaços e situações que se tornaram alvos desse tipo de saber. Através da literatura e de obras de cunho histórico e 
sociológico, sabe-se que as decisões sobre o casamento, especialmente nas classes mais abastadas, eram tomadas pelos pais, sem se levar em consideração a idade da moça, mas tão-somente sua capacidade em produzir filhos. Médicos como Afrânio Jorge e Manuel Ramalho começaram a criticar esse monopólio familiar e a exercer sobre as famílias uma certa pressão amparada pela autoridade do seu saber, a fim de dissuadir os pais dessa prática que, certamente, devia causar muitos problemas para jovens recém-saídas da infância.

A preocupação dos médicos com a higidez dos corpos é decorrente de uma mudança na auto-representação desses profissionais. Se até meados do século XIX seu papel se restringia a atender aos doentes, a reconhecer os males pelos seus sinais e a providenciar os meios terapêuticos, a partir de então passaram a defender uma inserção social mais ampla, justificando-a com discursos médico-políticos nos quais os corpos não são apenas expressão da criação divina, mas instrumentos, superfícies para a aplicação de diferentes forças que os tornavam úteis, de acordo com a sua natureza. É essa mudança que explica a 'construção' de diferentes corporalidades: dos trabalhadores, das crianças, dos loucos, dos negros e das mulheres.

O ponto de partida do conhecimento médico foi a puberdade, definida como uma fase da vida das mulheres marcada por grandes transformações físicas e emocionais, sendo, por este motivo, estudada minuciosamente. Como expressou o Dr. Francisco Carvalho (1914: 10), "é a época da vida feminina que mais tem sido cantada pelos poetas e que tem despertado a atenção dos ginecologistas".

Não muito distantes dos poetas, os médicos esmeravam-se para descrever essa fase usando metáforas poéticas. A mulher-flor das poesias também está presente nas teses médicas: "Chegada a puberdade, a moçoila é comparada, na frase de um grande poeta, à flor em botão que recebe as últimas gotas do orvalho matutino para poder desabrochar. A natureza como que dá os últimos aperfeiçoamentos ao material estético por ela acumulado"(Carvalho, 1914: 10).

Essas metáforas revelam como a púbere despertou sentimentos contraditórios nos médicos. Por um lado ela fascina, pois tudo nela lembra o frescor da juventude e a beleza, movida por uma energia que ainda é bastante infantil na sua expressão. Por outro lado, causa temores e receios, pois a extensão das transformações que se dão no corpo e no espírito da jovem mulher eram vistas como predisponentes a estados mórbidos que podiam levar a comportamentos desviantes e até mesmo à loucura. Como 
um ser liminar, a púbere ainda não era uma mulher, mas já deixara de ser uma criança. Os médicos fazem, então, um verdadeiro inventário, mapeando seu corpo nos mínimos detalhes, bem como descrevem todas as transformações que essa mudança física operava no comportamento.

Usava-se muito a palavra metamorfose para definir as mudanças registradas no inventário médico do corpo feminino: "A rapariga sai transformada desta crise: a modesta crisálida de ontem transformou-se na mimosa borboleta de hoje, como muito bem disse o poeta." (Ribeiro, 1907: 45). Geralmente, o inventário era realizado de fora do corpo para o seu interior e deste para o que os médicos chamavam de alterações no psiquismo.

Da superfície corporal nada escapava ao olhar investigador. A pigmentação mais acentuada em algumas partes do corpo, o aumento de pêlos nas axilas e na região pubiana, o aumento das secreções sebáceas e sudoríparas responsáveis pelo que foi chamado de odor di femina, eram alguns dos sinais indicativos da metamorfose do corpo feminino. Há uma certa unanimidade quanto à apreciação estética dessas alterações, em especial a distribuição do tecido adiposo nos quadris e aumento do volume dos seios, considerado por alguns autores como o ornato mais nobre do sexo feminino.

Mas a observação detalhada e minuciosa direcionava-se para os órgãos genitais e a menstruação, o que é bastante coerente com a visão que os médicos tinham a respeito da mulher como reprodutora. Referindo-se a essas transformações, o Dr. Pedro Soares (1913: 8) diz que as novas formas do corpo feminino parecem "adivinhar logo o papel que a mulher é destinada a representar como ser, [daí que] é em torno dos órgãos mais diretamente associados à reprodução que se agrupam as principais modificações." Soares refere-se à simpatia entre útero, ovários e mamas, bem como às alterações na genitália feminina, todas detalhadamente descritas pelos autores que abordaram o tema da puberdade.

Geralmente os órgãos genitais externos eram comparados a pétalas de flores, sendo descritos em detalhes anatômicos, como o tamanho do clitóris, a forma e a espessura do hímen. Da mesma forma, a vagina, o útero e os ovários foram descritos obedecendo aos critérios anatomofisiológicos de forma e função. Para resumir todo esse conjunto de transformações, os autores das teses usaram uma descrição que foi elaborada pelo Dr. Berthier (1874: 235236), autor de um livro conhecido e citado pelos brasileiros sobre as patologias mentais relacionadas à menstruação: 
[Com a puberdade] a bacia se amplia, o monte de Vênus escurece, os lábios, que Lineu comparou a pétalas de flores, desabrocham, e as paredes da vagina se umidificam com um líquido que exprime seu grau de sensibilidade. Ao mesmo tempo o tórax se apruma, as glândulas mamárias aumentam de tamanho, os seios se arredondam e se projetam e o contorno do corpo tem formas graciosas como se fosse a última pincelada da natureza. Enfim, a fisionomia se anima, os olhos, de infantis, se transformam em expressivos e cheios de atrativos.

Descrições anatomopoéticas como essa evidenciam não só o fascínio que o corpo feminino exercia não apenas entre os poetas, escritores e amantes da tão propalada beleza feminina, mas igualmente a necessidade de os médicos recorrerem a um vocabulário bastante erotizado, estranho à sisudez e à objetividade da Ciência, como se apenas esse tipo de linguagem metafórica conseguisse representar as transformações físicas que tornavam a mulher um ser reprodutivo e sexualmente atrativo.

No entanto, essas transformações nem sempre resultavam no belo e hígido corpo da mulher reprodutora. Conforme analisamos no capítulo anterior, a medicina e a biologia haviam encerrado a mulher nas cadeias de uma lei biológica segundo a qual os órgãos sexuais estabeleciam uma forte e inescapável relação de simpatia com o sistema nervoso, em especial com o cérebro. Essa relação explica o que os autores definiam como transformações psíquicas ou morais por ocasião da puberdade. Tais transformações podiam ser mais ou menos vagas e temporárias - até que a crisálida se transformasse em borboleta - ou permanecer na forma de patologias mentais, geralmente associadas à menstruação, denominadas hebefrenias. As transformações físicas comentadas eram, portanto, interpretadas como a fonte das alterações psíquicas e intelectuais que os médicos viam como inerentes à puberdade nas mulheres. A descrição dessa fase aponta para estados de melancolia, crises de choro, desejos vagos, mudanças de conduta, enfim, manifestações do que foi chamado de puberdade do espírito.

Esse momento despertou apreensões nos médicos, levando-os a prescrever regras de conduta para as jovens moças, alertando suas famílias para o risco que elas corriam em um momento de tamanha fragilidade físicoemocional, estando sujeitas a 'quedas fáceis' se influenciadas por um ambiente nocivo ou por más companhias: "Nas pensões, nos conventos, nos liceus, companheiras mais adiantadas iniciam [a adolescente] e se encarregam desta educação especial. Entregue a si mesma, às suas reflexões, muitas vezes ela é 
levada a pensamentos maus e a atos repreensíveis. A menina ingênua tornase uma moça precoce" (Soares, 1913: 15). A citação, embora econômica nas palavras, mostra a preocupação dos médicos com a sexualidade feminina, que deveria ser controlada até o momento adequado do casamento. Há muitas referências nas teses a respeito da educação moral das adolescentes, justamente para prevenir a precocidade sexual.

De todas as transformações ocorridas no corpo feminino nenhuma despertou tanto a atenção e estimulou a pena dos médicos quanto a menstruação. Foi objeto de teses de ginecologia, obstetrícia, higiene, fisiologia, medicina legal e psiquiatria, por se tratar de um fenômeno que, segundo a visão médica, colocava a mulher no limiar da fisiologia e da patologia durante toda a sua vida reprodutiva. Tomando-se o conjunto das teses e dos livros que influenciaram os seus autores, percebe-se a tendência em se dar maior ênfase às patologias menstruais do que ao fenômeno fisiológico em si, pois era papel dos médicos conhecer os entraves que porventura obstassem o destino natural da mulher. A menstruação era, portanto, mais um sinal da instabilidade da natureza feminina, confirmador da tese que a mulher não tinha controle sobre si, pelo menos não como os homens, pois sua razão e seus sentimentos estavam na dependência de um fenômeno que podia ser patológico.

A questão era tão instigante que mesmo aqueles que não eram médicos se debruçaram sobre ela, como é o caso de Michelet, que tratou da questão da menstruação nos seus livros O Amor, de 1858 e A Mulher, de 1859, trazendo para o público leigo informações restritas ao círculo médicocientífico. No livro A Mulher, Michelet abusou das metáforas para a falar das metamorfoses que se davam no corpo da jovem, entre elas a menstruação.

Ela acabava de fazer catorze anos em maio. Eram as primeiras rosas. A primavera, após algumas chuvas, daí em diante bela e firme, ostentava todas as suas pompas. Também ela tivera um pequeno momento tempestuoso, de febre e alguns sofrimentos. Saía pela primeira vez, um pouco fraca ainda, um pouco pálida. (...) Ela não era muito alta; mas seu corpo mudara, ficara graciosamente esguio. Tendo-se deitada criança, em poucos dias, levantara-se mocinha. Mais ligeira e contudo menos ágil, já não merecia o nome que lhe dava a mãe: Meu passarinho! minha borboleta! (1995: 110)

Autores como Pouchet, Raciborski e Bischoff foram os primeiros a tratar da menstruação como uma função relacionada à atividade dos ovários e do útero; abandonaram por completo as teorias antigas e criaram um novo campo de estudos médico-científicos: a emenologia. Raciborski (1868) 
conta que quando iniciou seus estudos de emenologia em 1839 havia pouca documentação sobre o assunto, o que o levou a solicitar aos seus colegas de outros países que elaborassem estatísticas e coletassem o maior número possível de informações clínicas.

Foi com base em ampla pesquisa realizada em países tão diferentes, como França, Suécia, Polônia, Rússia e alguns países da Ásia, que Raciborski, elaborou sua teoria da menstruação trabalhando com uma série de variáveis, construindo assim, sua opinião acerca do assunto.

No Brasil, pode-se perceber, devido às freqüentes citações encontradas nas teses, que as faculdades de medicina adotaram o livro de Raciborski. Pode-se mesmo dizer que todas as teses que trataram do assunto seguem a mesma orientação do autor: discussão sobre a menarca, definição da menstruação, higiene da puberdade, patologia da menstruação e terapêuticas.

A menarca foi um dos assuntos mais pesquisados por Raciborski, que não fixou uma idade para a primeira menstruação, mas salientou que diferentes variáveis exerciam sua influência, como o clima, temperatura média, a posição social e a raça. Os quadros estatísticos apresentados pelo autor, elaborados a partir de dezenas de milhares de observações reforçam o determinismo de algumas conclusões posteriores ao seu trabalho. Uma delas é a correlação entre climas quentes e úmidos e a precocidade sexual das mulheres. Sabe-se que esta correlação foi muito utilizada nos estudos racialistas do século XIX, que também se referiam à facilidade que as mulheres provenientes de países tropicais tinham para dar à luz.

O Dr. Afrânio Jorge (1905) criticou abertamente o determinismo geográfico e climático dos pesquisadores europeus e suas afirmações de que, na América do Sul, na África e Ásia, a menarca ocorria entre oito e dez anos, havendo mães de família com até treze anos de idade. O autor diz que aqueles que assim pensavam desconheciam o assunto, já que no Brasil não havia tal precocidade sexual entre as meninas. O médico ainda lamentou a ausência de estudos específicos sobre a idade da menarca no Brasil, mas, com base em uma 'estatística modesta' que realizou na Bahia, pôde afirmar que a média era de 12 anos e 13 dias; isto quer dizer que o determinismo de algumas explicações não foi aceito passivamente pelos médicos que percebiam a complexidade da questão. ${ }^{16}$

Estabelecida a menstruação, os autores trataram de definir o fenômeno, estudando-o primeiro sob o ponto de vista da fisiologia. Como um quadro, o corpo feminino retrata as alterações provocadas pela 
menstruação, como dores, tumefações, calores, tristeza, enfim, um conjunto de sintomas denominados de molímen menstrual. Na sua busca pela precisão, os autores mediam a quantidade de sangue eliminado pela menstruação, bem como investigavam a sua composição química. Mas grande parte dos estudos sobre a menstruação refere-se à higiene e à prescrição de condutas adequadas para evitar estados mórbidos.

Os médicos são unânimes na prescrição de cuidados higiênicos para a jovem. Raciborski (1868) comenta que o médico deveria exercer junto às famílias o papel de conselheiro a respeito da manutenção da saúde e agir junto às mães, principalmente as que teriam maior ascendência sobre as filhas. Quase todas as teses referem-se à influência negativa que a vida mundana teria sobre a adolescente. Assim, criticam os excessos de estudos para as moças, pois o esforço intelectual podia colocar em risco a sua saúde.

Em uma das teses mais interessantes Afrânio Augusto de Araujo Jorge diz que a educação intelectual não atraía os homens, mas "o rosto rosado de uma face bela, a elegância de um porte esbelto, que desperta esta simpatia que inclina o homem à mulher" (1905: 14). Araújo Jorge não era contra a educação das mulheres, mas ao que ele e seus contemporâneos consideravam excessos. A instrução das mulheres devia ser na medida exata para torná-las boas mães e não para concorrer com os homens em exames e concursos.

Condenava-se também com rigor a leitura de romances, citando-se com freqüência uma frase de Tissot, segundo a qual uma menina que lesse um romance aos 11 anos teria ataques de nervos aos 20. Da mesma forma, os médicos não viam com bons olhos as diversões noturnas como o teatro e os bailes. O primeiro podia impressionar demais o espírito das moças, além de ser um ambiente por demais carregado de emanações que prejudicavam a respiração. Os bailes eram vistos como nocivos por ocorrerem tarde da noite e por produzirem igualmente excitações nas impressionáveis raparigas.

Outra atividade muito condenada nas teses foi a música, embora o século XIX tenha sido a época da divulgação do seu ensino entre as classes médias e altas, principalmente o piano; esta manifestação artística era vista como uma distração para as moças, a música tornava-se para algumas uma verdadeira paixão, que, se exercida continuamente, podia excitar demasiadamente as jovens e levá-las a estados mórbidos. O Dr. Ramalho (1906) conta que uma jovem do high life baiano teve uma crise histérica depois de ouvir uma valsa executada por um violinista italiano. Esse fato, disse o autor, era 
um exemplo de como as jovens eram impressionáveis, sendo conhecidos casos em que se apaixonaram por professores de canto e de piano.

Todas essas prescrições higiênicas são indicativas da concepção liminar da adolescente e, em última instância, da mulher. Apontam para os estritos limites da normalidade e o quanto a própria natureza feminina seria responsável pelos desvios e manifestações mórbidas. De acordo com o Dr. Ramalho, todos os alertas médicos evidenciavam a necessidade de extremos cuidados com as jovens numa fase "em que sua alma qual chapa fotográfica não revelada, pode impressionar-se ao mais tênue raio de luz" (1906: 19).

Muitas páginas foram escritas sobre as boas normas higiênicas para a adolescente. Cuidados com a qualidade da alimentação, com a prática moderada de exercícios físicos e com o vestuário eram repetidos constantemente nas teses. Tem-se, desse modo, um amplo conjunto de interdições e de prescrições cujo objetivo era preservar a frágil saúde da adolescente. No entanto, todo o cuidado era pouco em se tratando da instabilidade do corpo feminino, como se pode observar pela grande atenção que mereceu a patologia da menstruação. Nesse sentido, cabe questionar até que ponto os especialistas da mulher estavam reproduzindo, sob a chancela da Ciência, antigas representações do corpo feminino, especialmente aquelas associadas às interdições e aos cuidados que a menstruação exigia.

Idéias que relacionavam purgação do sangue menstrual à impureza e à incapacidade tiveram e ainda hoje têm incrível vitalidade e aceitação, tanto nos textos médicos quanto na cultura popular. O que aqui se defende é que mesmo com os estudos fisiológicos sobre a ovulação nos mamíferos em curso desde meados do século XIX, a força das representações sobre a 'mulher que sangra' se impunha nos discursos médicos, ao mesmo tempo em que era operacional na manutenção e no reforço das relações assimétricas de gênero, associando a diferença 'debilitante' das mulheres à incapacidade de atuar nos mesmos espaços que os homens.

São essas considerações que explicam por que, mesmo sendo definida como um fenômeno fisiológico, a menstruação foi abordada com maior ênfase sob o ponto de vista da patologia. Fundamentados nas pesquisas anatomofisiológicas da ciência experimental, os médicos tinham como verdade inquestionável que as transformações nos órgãos genitais eram de tal magnitude que, pela ação simpática entre eles e o cérebro, podiam desencadear vários tipos de doenças mentais. Constrói-se uma imagem 
completamente instável do corpo feminino, como se estivesse sempre em eminência mórbida.

O famoso legista francês Tardieu declarou que o período menstrual marcado ou não por problemas específicos, como a amenorréia ou a dismenorréia, desempenhava um papel importante no desenvolvimento de neuroses e da loucura. Para aqueles que não acreditavam nas neuropatias menstruais, Tardieu (apud Berthier, 1874) respondia com 250 casos por ele mesmo observados, sendo um defensor convicto da teoria da organização nervosa do corpo feminino e das simpatias entre os órgãos genitais e o cérebro:

Efetivamente do nascimento à morte, a mulher percorre o círculo completo de suas obrigações e se encontra a cada dia submetida a uma grande quantidade de impressões e acidentes. De um lado o temperamento nervoso que a predispõe às reações do cérebro sobre a matriz; de outro lado, as atribuições da matriz regulando as reações sobre o cérebro, de tal forma que o cérebro e a matriz repercutem continuamente seus problemas e suas desgraças. $(1874: 11)^{17}$

Essa citação demonstra de forma inequívoca como os médicos negavam às mulheres qualquer possibilidade de intervenção ou de manifestação da subjetividade, já que nada havia de ser feito contra as leis da Natureza, visto que ela dividiu a espécie humana em dois gêneros desiguais; o feminino, aprisionado nas cadeias do corpo, no circuito neurorreprodutivo ininterrupto de ações reflexas; o masculino, definido pela racionalidade.

O que salientamos dessa discussão a respeito do papel debilitante da menstruação na vida das mulheres é o determinismo do discurso médico ao fundar na Natureza específica dos dois sexos diferenças comportamentais e até mesmo identitárias. Dessa forma, as mulheres não podiam escapar de seu destino biológico, cíclico e 'sangrento', enquanto seus companheiros de espécie, por não dependerem da ação de seus órgãos reprodutivos, podiam dar asas à racionalidade, escolher, individualizar-se, enfim, usar o corpo como instrumento de transcendência. Para as mulheres, portanto, só restava a imanência de seus corpos instáveis e saturados de sexualidade.

A menstruação foi vista como um importante fator de desequilíbrio do instável sistema nervoso da mulher e responsável por uma série de patologias mentais. ${ }^{18} \mathrm{O}$ inventário dessas doenças é muito extenso, o que despertou o interesse dos médicos legistas sobre as desordens nervosas relacionadas à menstruação. A tese defendida pelos legistas era de que muitas 
mulheres que cometiam crimes não podiam ser consideradas responsáveis pelo ato devido às desordens psíquicas provocadas pela menstruação. Em todo caso de crime praticado por mulher, o legista devia conhecer o estado menstrual e saber se o crime coincidia ou não com a menstruação.

Por fim, muito próxima às manifestações mórbidas, mas sem ser considerada como um fenômeno patológico, estava a menopausa, chamada de enfer des femmes por Raciborski (1868). Embora despertasse cuidados por parte dos médicos, a menopausa não mereceu a mesma atenção, nem o mesmo número de páginas nas teses e livros que a puberdade e as doenças causadas pela menstruação. Geralmente, descrevia-se rapidamente as transformações físicas que acompanhavam o desaparecimento da função reprodutiva. Os autores referem-se à menopausa como um momento de tranqüilidade e de sabedoria para as mulheres:

Na idade crítica a natureza parecendo transladar para o cérebro esta vitalidade que o sistema uterino era então a sede, a mulher, e aqui nos referimos àquela que recebeu uma certa educação, ou uma educação esmerada, torna-se notável pela profundeza de suas vistas e a justeza do seu parecer. (Moura, 1914: 45)

Os médicos criticavam as mulheres que não sabiam envelhecer com sabedoria, porque tornavam-se amarguradas diante da perda de seus atrativos físicos. Segundo Raciborski (1868), as mulheres deviam direcionar suas idéias e atividades para as obras de caridade e de beneficência, bem empregando seu tempo livre.

Ao término de seu ciclo reprodutivo, a mulher era comparada a um homem disfarçado; afinal, sua principal função chegara ao fim, liberando-a dos encargos e perigos a que foi exposta durante toda sua vida. Certamente, esta é a explicação para a economia de palavras a respeito da menopausa, a não ser quando apresentava manifestações mórbidas, como o alcoolismo, por exemplo. O interesse médico pelo corpo feminino restringira-se ao período em que a mulher exercia sua função reprodutiva e passava por várias transformações, como a puberdade, a gravidez e o parto chegando até o seu epílogo com a menopausa.

Se pela definição médica do sexo feminino a mulher era assim concebida por causa da menstruação e da maternidade, como definir a mulher que deixara de menstruar, já tendo criado seus filhos? Ao cessar o tempo dos mênstruos, que nova mutação ocorreria no corpo feminino? Os médicos não responderam a essas perguntas, deixando espaço para que 
outros o fizessem, como Michelet (1995), para quem a mulher madura, desincumbida das exigências do seu sexo, adquiria um bem precioso para as mulheres: a liberdade. Michelet (1995) diz que a mulher madura ou mesmo idosa podia desfrutar a liberdade de estabelecer novas relações de amizade, pensar ou falar com independência e originalidade. A metamorfose final que ocorria com a chegada da menopausa era, segundo o autor, a transformação da mulher nela mesma, pela primeira vez em sua vida. Citando uma bela frase de Madame de Sévigné, Michelet (1995: 278) encerra suas reflexões sobre a mulher madura: "Juventude e primavera são apenas o verde, e sempre o verde; nós, porém, as pessoas do outono, somos de todas as cores".

Certamente, Michelet estava se referindo a uma parcela muito reduzida de mulheres, pertencentes à mesma classe de Mme de Sévigné e não às camponesas e trabalhadoras manuais cujas condições de vida não eram nada propícias a conversações inteligentes ou alargamento dos horizontes. De qualquer forma, o autor reproduziu idéias e valores a respeito da menopausa que foram retiradas da leitura de tratados de emenologia, como o de Raciborski, por exemplo.

Refletindo sobre os conhecimentos divulgados pelas teses médicas, pode-se suspeitar ou até mesmo afirmar que os autores pouco conheciam o objeto de seus estudos. Muitas das teses não tinham nenhuma sustentação clínica e quando havia era de segunda mão, por assim dizer. Geralmente, tratava-se de citações de experiências de outros médicos, retiradas dos livros usados como fonte ou então a transcrição das observações que os professores comentavam nas aulas. Tendo em vista essa situação, o que se pode concluir é que os jovens recém-formados em medicina saíam com uma boa bagagem de idéias sobre o que imaginavam ser a mulher, esta categoria universal que não nasceu da costela de Adão, mas do discurso médico-científico produzido nos séculos XVIII e XIX.

\section{Notas}

1 Para uma discussão a respeito das alegorias femininas na cultura ocidental, ver o excelente livro de Warner (2000).

2 Sobre as relações conflituosas entre leigos e médicos no período colonial, ver M. M. Ribeiro (1997).

3 Sobre as sociedades científicas européias, ver Coser (1968). 
Livros de Matrícula dos doentes que entraram, saíram e faleceram no Hospital da Casa da Santa Misericórdia. 1847-1853. Arquivo da Santa Casa de Misericórdia de Salvador.

$6 \quad$ IS $^{3} 9$ Ofício da Provedoria da Santa Casa ao Ministro de Estado. 8-5-1872. Ministério do Império - Santa Casa de Misericórdia. Arquivo Nacional.

7 Ata da Sessão da Mesa e Junta da Santa Casa de Misericórdia do Rio de Janeiro, 2-41883. IS ${ }^{3} 9$ Ministério do Império. Arquivo Nacional.

8 Logo após a Reforma Sabóia, quando a clínica obstétrica e ginecológica começou a funcionar no Hospital da Santa Casa, o movimento de pacientes era bastante significativo, tendo em vista a precariedade do hospital. Entre 1883 e 1884 foram atendidas no consultório ginecológico 2.467 mulheres e aviadas 4.919 receitas. Relatório da Santa Casa de Misericórdia. Hospital Geral. Arquivo Nacional.

9 Ofício da Faculdade de Medicina do Rio de Janeiro, 01-03-1883. Ministério do Império. Arquivo Nacional.

10 Sobre as concepções que orientaram a reforma hospitalar na Europa, ver Foucault (1985). O hospital Santa Isabel funciona no mesmo prédio, no bairro de Nazaré.

${ }^{11}$ Ver em Lobo (1982). Há que se salientar que o acervo da biblioteca da Faculdade de Medicina do Rio de Janeiro (FMRJ) contava com um número superior de volumes do que a biblioteca da Faculdade de Medicina da Bahia (FMBA), de acordo com a pesquisa realizada por Ribeiro (1997).

12 Fabíola Rohden (2001) fez um levantamento das teses da Faculdade de Medicina do Rio de Janeiro (FMRS) selecionando 1.593 títulos referentes à sexualidade e à reprodução. Deste total, destacam-se as teses sobre gravidez, parto e puerpério, além daquelas que tratam dos órgãos reprodutivos femininos, o que é um indício de como a obstetrícia e a ginecologia despertavam o interesse dos estudantes de medicina em meados do século XIX.

13 Um trabalho pioneiro com esse tipo de documentação é o de Nunes (1983).

14 Refiro-me ao aumento significativo da gravidez na adolescência que vem se tornando um assunto de interesse multidisciplinar não só no Brasil, mas em alguns países mais desenvolvidos, como é o caso da Inglaterra, com altos índices de gravidez precoce.

15 Analisando as teses de higiene, percebe-se que o discurso médico a respeito do corpo masculino restringe-se aos controles para evitar os excessos sexuais e o desperdício da energia masculina através da masturbação. O interesse médico pelo púbere era mais direcionado para o controle de si mesmo, para a definição de padrões comportamentais que adestrassem o corpo para o trabalho e para o exercício racional e econômico da sexualidade. Sobre esta questão, ver Baker-Banfield (1972) e Gay (1988).

16 De acordo com Laslett (1971), a idade da menarca varia no tempo, de classe para classe e de lugar para lugar. Há também que se considerar o papel da nutrição que deve ter colaborado significativamente para as variações.

17 A declaração de Tardieu foi usada por Berthier (1874) como epígrafe no seu livro.

18 A respeito dos discursos médicos sobre a menstruação, ver Showalter \& Showalter (1994). 


\section{O Médico de senhoras e a clinica de Mulheres}

Corria o ano de 1897 e o jovem Afrânio Peixoto acabara de defender a tese Epilepsia e Crime com a qual obtivera o título de doutor pela Faculdade de Medicina da Bahia, vindo a tornar-se um dos nomes de maior prestígio da medicina legal do século XX. Antes de enveredar pela pesquisa e pelo ensino universitário, Peixoto tentou dedicar-se à clínica, deixando Salvador para começar a exercer sua profissão na pequena cidade de Canavieiras, na região cacaueira. No relato que faz desta experiência, conta que sua orgulhosa mãe o presenteou com um conjunto de diferentes instrumentos cirúrgicos vindos da Europa, entre eles alguns instrumentos obstétricos e ginecológicos. Mal podia imaginar a sua mãe que aquele presente levaria Peixoto a mudar o rumo de sua vida profissional, deixando de ser médico interiorano para ser o cientista renomado na capital federal.

Recém-chegado a Canavieiras, espalhou-se a notícia de que o jovem doutor tinha muitos aparelhos de curar, ampliando-se a clientela, até que então ocorreu um chamado para atender a uma parturiente:

Certa noite fui acordado para socorrer uma pobre senhora em trabalho de parto, visto que sabiam que eu tinha um fórceps moderno, recém-chegado da Europa. Foi com a morte na alma que me vesti para sair, a caixa do fórceps debaixo do braço. Sabia das minhas responsabilidades quanto à esterilização, mas como esterilizar um fórceps em casa humílima tendo apenas água fervendo? Depois, como aplicá-lo sem perigo, eu que apenas me recordava da regra mnemônica que, em boa hora, me fizera reter o meu professor Climério de Oliveira. Fui pelo caminho repetindo isso. Ao chegar a uma pobre casa de Birundiba, encontrei uma pobre mulher exausta de soprar numa garrafa, fazendo esforços inúteis. Foi preciso pô-la em repouso, dar-lhe algo a beber para reanimar, esterilizar o meu fórceps e, milagre da natureza! Antes da minha intervenção, nascia a criança. Medo 
do instrumental? Ou a confiança, da ignorância, na presumida ciência? Eu de fato afirmara que tudo ia correr bem, logo que ela descansasse. No dia seguinte eu era um herói em Canavieiras, havendo estreado, diziam, o meu fórceps, com plenos resultados. O terror da responsabilidade nessa noite foi de tal ordem, que resolvi não ser clínico, não aventurar a vida dos outros à minha incapacidade. Peguei de todo o instrumental, ofereci a um insipiente hospital de Canavieiras e decidi-me a não fazer clínica aí, onde eu seria forçado a exercitar todo o meu aparelho cirúrgico. Que carnificina. (Peixoto apud Ribeiro, 1950: 31-32)

Essa incrível experiência de um dos mais respeitados professores e cientistas brasileiros é interessante sob vários aspectos. Pode-se perceber a reação positiva das pessoas à chegada de um jovem médico munido com instrumentos cirúrgicos modernos, comportamento este que revela uma mudança de atitude em relação à confiança nos médicos e nas suas artes de curar. Contudo, o que é mais instigante no relato de Peixoto é a sua sinceridade em admitir não estar preparado para exercer a clínica médica, constatação a que chegou a partir do atendimento a uma parturiente. Esta admissão de incapacidade é muito rara de ser encontrada, mesmo em casos de denúncia de negligência ou imperícia médica, os médicos eram muito cuidadosos no uso de palavras que podiam colocar em suspeição a formação do profissional em questão. Ao enfrentar um parto, Peixoto admitiu as falhas de sua formação, não se deixando levar pela presunção de que bem armado com fórceps, ganchos, basiotribos e outros instrumentos podia se tornar um parteiro da noite para o dia.

\section{O Médico de Senhoras: um novo campo da prática médica}

O caso de como o Dr. Afrânio Peixoto desistiu da clínica demonstra muito bem as condições do ensino da obstetrícia no Brasil, conforme analisamos anteriormente. Embora Peixoto tivesse realizado seus estudos em uma época em que já havia o ensino clínico das duas especialidades, a obstetrícia e a ginecologia, há que se questionar sua eficácia, tendo em vista a referência que faz à regra mnemônica do Dr. Climério, um recurso didático, deste que foi um dos mais importantes obstetras baianos do século XIX, usado para que os alunos memorizassem a aplicação do fórceps e para aprender os tempos do trabalho de parto. ${ }^{1}$ Provavelmente, Peixoto não assistira a nenhum parto, ou pelo menos não um parto que necessitasse de intervenção com fórceps, o que explica o seu 'terror da responsabilidade' pela vida alheia. 
O retrato expõe com uma certa dramaticidade a realidade que a maioria dos médicos recém-formados enfrentava ao voltar para suas cidades ou, como foi o caso do Dr. Peixoto, ao começar a profissão em uma pequena cidade do interior: o despreparo devido à falta de experiência clínica, especialmente nas áreas de obstetrícia e ginecologia. Mais de meio século de ensino médico no Brasil e os defeitos na formação ainda se faziam presentes, muito mais nos casos obstétricos que mereciam intervenção médica. Infelizmente, não temos como avaliar com mais precisão os danos causados tanto por médicos mal preparados quanto pelas parteiras não diplomadas - que eram a maioria -, mas podemos ter uma idéia da dimensão do problema tendo em vista as críticas que vieram a público na época e posteriormente, em avaliações de cunho histórico.

Fernando Magalhães (1922b) não poupou críticas ao passado das duas especialidades no Brasil, lembrando que poucos foram os médicos habilitados e interessados em exercer a obstetrícia até meados do século XIX. Segundo o autor, isto se deu porque aqueles que fizeram seus estudos em Portugal vinham com muitas falhas em sua formação, pois a obstetrícia permaneceu por muito tempo ainda presa às práticas e teorias tradicionais na medicina portuguesa, prevalecendo a autoridade dos textos antigos em detrimento da experiência clínica. ${ }^{2}$ Mesmo aqueles que estudaram em centros de reconhecido desenvolvimento obstétrico, como a faculdade de Medicina de Paris ou de Edimburgo, não se tornaram parteiros famosos. No seu relato, Magalhães (1922b) apresenta um quadro desolador da obstetrícia brasileira do século XIX, criticando os médicos por sua falta de interesse e despreparo e as parteiras pela ignorância.

Certamente, Magalhães não levou em consideração que até o momento em que os médicos começaram a se preocupar com o ensino e a prática da obstetrícia, o atendimento às grávidas e parturientes, aos recém-nascidos e às doenças ginecológicas era feito pelas parteiras e que estas não compunham uma categoria homogênea de 'mulheres velhas e paupérrimas', incultas e supersticiosas. De acordo com Maria Lúcia de Mello Souza (1998), havia tipos diferentes de parteiras com níveis de conhecimento variados sobre o parto, sendo a maior parte delas habilitadas para assistir as parturientes, o que explica o reconhecimento por parte da clientela e o longo período de tempo que muitas delas exerceram o ofício. ${ }^{3}$

Para o Dr. Fernando Magalhães e outros médicos que se juntaram a ele nas suas críticas, a história da obstetrícia não se confundia com a milenar prática das parteiras. A história que os médicos sancionavam era da evolução 
do conhecimento científico, da tecnologia e da cirurgia conduzidos pela racionalidade dos 'pais da obstetrícia' e seus seguidores nos espaços exclusivos das faculdades de medicina, onde poucas parteiras puderam entrar e somente como discípulas dos médicos. Magalhães e seus colegas não se opunham ao ofício das parteiras; ao contrário, seguindo uma orientação européia, defendiam a necessidade de parteiras bem informadas na ciência obstétrica para atender os partos naturais e saber reconhecer os problemas contanto que não agissem por conta própria e chamassem o médico caso fosse necessário. Em seu livro, Magalhães (1922b) refere-se a algumas representantes cultas e dignas do ofício das parteiras, como a famosa Mme. Durocher, a quem ele reconhece a competência e a generosidade.

Apesar da fama que tantas parteiras tiveram, dos constantes agradecimentos que recebiam e do número significativo de anúncios de seus serviços nos jornais da época, como bem analisou Souza (1998), a maioria foi estigmatizada pelo discurso médico como representante da ignorância e do atraso, sendo colocada à margem da história da obstetrícia. Assim, entende-se por que o Dr. Fernando Magalhães, historiador oficial da obstetrícia no Brasil, só conseguia ver, no período anterior à medicalização do parto, uma época de descaso dos médicos e atraso das parteiras.

Mas, por que motivo os médicos não se mostraram interessados pelos partos e pelas doenças ginecológicas? Embora no Brasil não tenhamos testemunhos de uma reação negativa à entrada dos médicos na cena do parto, como ocorreu na França, há referências à desimportância dada ao atendimento obstétrico, herança da medicina portuguesa e de uma tradição bem consolidada no meio médico. Esta indiferença foi bem observada por um médico bastante influente na Corte, Dr. José Francisco Sigaud, defensor do ensino prático de partos para médicos e parteiras. Em seu artigo sobre a questão, publicado em 1835, o Dr. Sigaud comenta que havia uma idéia bastante generalizada entre os próprios médicos de que entre os povos primitivos e nos climas quentes, os partos transcorriam normalmente, sem a necessidade de alguém para intervir a não ser uma parteira para aparar a criança. A formulação desta idéia é contemporânea à expansão colonial européia e às narrativas dos viajantes a respeito dos povos primitivos e seus costumes. Segundo os primeiros etnógrafos da modernidade, as mulheres negras ou indígenas tinham muita facilidade em dar à luz e quase sempre o faziam sozinhas, voltando logo em seguida às suas atividades. Esses relatos instigaram alguns médicos a desenvolver 
o que podemos chamar de uma obstetrícia antropológica, voltada para o inventário dos costumes obstétricos dos povos não-europeus, divulgandoos através de livros ricamente ilustrados.

Os defensores da ciência obstétrica não se cansaram de rebater essas idéias questionando o valor das observações dos viajantes e demonstrando com suas experiências pessoais a existência de casos que exigiam a atuação de um médico treinado em obstetrícia. Dr. Sigaud (1835) era um destes defensores e rejeitava a suposição dos médicos brasileiros de que as escravas e as índias pariam sem necessitar de ajuda. O problema, segundo Sigaud, estava na falta de divulgação dos 'casos funestos', diferentemente do que ocorria na Europa, onde os casos obstétricos complicados eram publicados na imprensa. Esta seria a explicação para a crença de que em uma cidade de clima quente como o Rio de Janeiro não ocorriam partos difíceis. Sigaud rejeitava inteiramente o que para ele era tão-somente uma crença, sem nenhuma sustentação em fatos, nem em estatísticas, e cita suas próprias experiências, contando ter observado jovens escravas com diâmetros pequenos da bacia cuja parturição foi penosa, pois haviam engravidado muito jovens. Comenta ainda ter visto diversos casos complicados e até fatais para as mulheres e os recém-nascidos, como hemorragias, convulsões, peritonite e rupturas de útero, o que o levou a defender a urgência de uma clínica de partos na Corte.

Mesmo sem contar com estatísticas, há relatos médicos sobre níveis alarmantes de mortalidade materna, atribuídos ao descaso dos médicos, à precariedade do ensino obstétrico e à ação das parteiras não diplomadas, chamadas também de 'comadres' e 'curiosas'. Certamente, havia algum exagero em afirmações como as do Dr. Nunes Garcia (apud Magalhães 1922b: 128), ao dizer que "na classe das mortes por parto esta cidade e mesmo o Brasil todo exorbita as demais nações do mundo". Contudo, não se pode subestimar esses relatos que, somados às observações dos viajantes europeus que passaram pelo Brasil no século XIX, apresentam um quadro bastante inquietante quanto à mortalidade materna.

Informado pelos viajantes, Gilberto Freyre (1992: 346) refere-se aos casamentos precoces de meninas-moças, as "iaiás das casas grandes", que, aos treze anos, ou até mesmo aos doze, já eram encaminhadas para o casamento. Segundo Freyre, muitas dessas meninas não sobreviviam ao primeiro parto, apesar dos rogos à Nossa Senhora do Bom Parto e, certamente, dos esforços das parteiras, que pouco podiam fazer para salvar 
meninas cujos corpos não estavam suficientemente desenvolvidos para suportar os encargos físicos de uma gestação e os riscos da parturição.

Se tomarmos como referência os estudos demográficos sobre a mortalidade feminina na Europa e nos Estados Unidos, veremos que, em relação aos homens, os índices mantiveram-se mais elevados até a década de 70 do século XIX, sendo a tuberculose a primeira causa da mortalidade feminina. As mortes relacionadas aos partos aumentaram significativamente nos países onde as mulheres passaram a ser atendidas nos hospitais e maternidades, devido à infecção puerperal, apesar dos esforços médicos empreendidos após a década de 70 daquele século para debelar este verdadeiro flagelo. As pesquisas mostram que a queda da mortalidade materna só começou a ocorrer após a Primeira Guerra Mundial. ${ }^{4}$

No Brasil, os atendimentos obstétricos foram majoritariamente domiciliares até o final do século XIX, não se verificando a epidemia de infeç̧ão puerperal que ocorreu nos hospitais europeus. Portanto, há que se considerar os partos difíceis, as hemorragias e a eclâmpsia como complicações puerperais para as quais os médicos e muitas parteiras não estavam preparados e que, conseqüentemente, devem ter contribuído para o aumento da mortalidade materna, conforme denunciado pelos relatos da época.

Outro aspecto a ressaltar do tom dos discursos adotados pelos críticos é o impacto psicológico da morte causada pelo parto. Autores como Laget (1977) e Shorter (1984) concordam que, comparativamente, o número de partos difíceis era muito menor do que o de partos naturais, e a possibilidade concreta de um parto assim resultar na morte da mãe e quiçá da criança gerava uma forte impressão coletiva de medo e fatalidade. Portanto, mesmo que a mortalidade materna no Brasil não diferisse muito do que ocorria em outros países talvez até fosse menor para o período anterior a 1870, quando a intervenção médica era mais rara e, conseqüentemente, os riscos de infecção menores o impacto era considerável, gerando acusações e arruinando reputações.

Tal estado de desinteresse não parece ter se alterado pelo menos até a década de 50 do século XIX. A partir de então, alguns médicos começaram a se dedicar mais à obstetrícia, mesmo que ainda não fosse uma atividade lucrativa, afinal, a clientela era bastante fiel às parteiras. ${ }^{5}$ Médicos como o Dr. Feijó, Dr. Sabóia, Dr. Rodrigo de Bivar, a parteira Mme. Durocher e outros tantos passaram a divulgar conhecimentos, opiniões e observações clínicas nas publicações médicas que surgiram no Brasil como a Revista Médica Fluminense (1835-1841) e os Anais Brasilienses de Medicina (1850-1885), 
publicação oficial da Academia Imperial de Medicina, onde também se davam os debates a respeito de questões clínicas, científicas e profissionais.

Começava-se a ter um ambiente propício ao desenvolvimento da obstetrícia, como se pode ver pelo aumento no número de teses de conclusão dos cursos de medicina a partir da década de 50 do século XIX, bem como de outras publicações de caráter didático como O Médico da Primeira Infância e o Conselheiro da Mulher Grávida (Magalhães, 1922b: 240), de Antônio Ferreira Pinto, publicados em 1859, e o Manual da Parteira ou Pequena Compilação de Conselhos na Arte de Partejar (1922b: 240), de Joaquim Antônio Alves Ribeiro, publicados na província do Ceará em 1861.6 As críticas ao descaso dos médicos e das autoridades com a mortalidade materno-infantil e a defesa de um ensino clínico de partos são contemporâneos à formulação de discursos médicos, na sua maioria, mas também jurídicos e literários, a respeito da família e dos papéis de gênero.

Como bem observou Jurandir Freire Costa (1979), já na metade do século XIX percebe-se um clima intelectual influenciado pelas publicações européias contrário à reclusão das mulheres da elite e à vida desregrada das mulheres do povo. A preocupação com a gravidez e o parto integra, portanto, uma nova visão a respeito da mulher, cujo corpo devia ser fértil e saudável a fim de cumprir a função materna, revestida de um novo simbolismo político. Ou seja, o que os médicos do século XIX pretendiam inculcar nos corpos e mentes das mulheres era que sua natureza não estava somente à disposição de interesses egoístas ou particularistas, como a transmissão do sangue e do nome da família, mas de valores muito mais importantes e coletivos, como a raça, o vigor de um povo, o sangue de uma nação. Assim, médicos e outros intelectuais do final do século XIX procuraram transformar a maternidade em uma função política de extrema importância para ser abandonada às mãos de leigos.

Além da ampliação do debate médico sobre a obstetrícia, as inovações clínicas e cirúrgicas introduzidas pela ciência francesa e inglesa já eram bem conhecidas pelos médicos brasileiros, afinal, alguns deles estudaram na França, outros empreenderam viagens de pesquisa ao exterior ou então tiveram acesso aos conhecimentos através dos livros e periódicos estrangeiros adquiridos pelas bibliotecas das faculdades do Rio de Janeiro e da Bahia. ${ }^{7}$

Outra evidência bastante importante sobre o crescente interesse médico pela obstetrícia e a ginecologia foi o aumento do número de clínicas privadas para atender a parturientes e doenças de senhoras. Os jornais que já traziam 
anúncios dos serviços prestados por parteiras começaram a publicar anúncios de clínicas mantidas por médicos, como o Dr. Chomet, o Dr. França e o Dr. Eiras, voltadas para o atendimento de pessoas com algum recurso; também atendiam as escravas que os senhores enviavam para dar à luz a fim de garantir seu investimento, conforme interpretação de Magalhães. Provavelmente Magalhães estivesse certo, afinal, desde o início do século já havia uma orientação nesse sentido, ou seja, de que os senhores deviam cuidar melhor das escravas grávidas e dos seus filhos recém-nascidos tendo em vista proteger não apenas a saúde e o bem-estar das escravas, mas, igualmente, os seus próprios interesses.

Além das clínicas mantidas por médicos e parteiras, alguns médicos, reconhecidos pela perícia com que atendiam as parturientes e pelo saber que demonstravam, passaram a ser chamados pelas mulheres mais ricas a fim de atendê-las nos seus partos realizados em casa, o que contribuiu para a divulgação da prática e a construção da fama de médicos como o Dr. Luiz da Cunha Feijó, catedrático da Cadeira de Partos da Faculdade de Medicina do Rio de Janeiro (FMRJ) e parteiro da Princesa Isabel, que teve uma grande clientela na Corte entre as décadas de 1850 e 1870.

Embora a maioria das mulheres continuasse a chamar as parteiras para atendê-las no momento de dar à luz, também no Brasil deu-se o mesmo movimento em direção aos médicos-parteiros, cuja clientela era inicialmente bastante diferenciada. Feijó atendia tanto as mulheres muito pobres na enfermaria de partos da Santa Casa, como as esposas de Ministros do Império e a própria filha do Imperador. O mesmo se dava com outros médicos parteiros, que, ao longo da segunda metade do século XIX, adquiriram fama e foram conquistando clientela. No entanto, o costume de chamar o médico para atendimento domiciliar permaneceu restrito às elites e às camadas médias urbanas até o século XX, quando os obstetras brasileiros começaram uma verdadeira campanha de convencimento sobre as vantagens e a segurança do parto hospitalar em relação ao domiciliar. Até então, os médicos-parteiros atendiam somente mulheres sem nenhum recurso, na Santa Casa e depois nas maternidades, ou as senhoras brancas endinheiradas que podiam pagar o atendimento exclusivo junto ao seu leito.

Apesar das restrições, alguns médicos parteiros da metade do século XIX tornaram-se referência para seus alunos, sendo constantemente citados nas teses pela experiência clínica e pelas opiniões a respeito de pontos polêmicos, como o uso de anestésico no parto, a aplicação do fórceps ou as cirurgias obstétricas, o que demonstra como estavam informados do 
conhecimento obstétrico produzido no exterior, procurando, dentro do possível, colocá-lo em prática no atendimento às mulheres.

Os obstetras mais destacados na clínica e no ensino atuaram também na política. Alguns conquistaram títulos de nobreza, como o baiano Dr. Adriano Alves de Lima Gordilho, Barão de Itapoan, e o Dr. Luiz da Cunha Feijó, Visconde de Santa Isabel. Outros foram deputados e senadores, e o Dr. Francisco Werneck de Almeida, primeiro ginecologista brasileiro, foi prefeito do Rio de Janeiro entre 1895 e 1897. As biografias dos mais destacados obstetras e ginecologistas brasileiros que atuaram após 1870 apontam para alguns traços em comum, como a origem social, sendo a maioria deles oriundos de famílias ricas ou de segmentos médios urbanos concentrados no comércio e no serviço público. Outra característica comum foi a inclinação para a pesquisa científica, ou seja, muitos desses médicos participaram ativamente de sociedades e associações científicas e profissionais no Brasil e também no exterior, produzindo algumas obras de grande aceitação e fundamentação clínica adquirida em hospitais brasileiros e estrangeiros. ${ }^{8}$

Tomando como referência a contínua ação dos médicos especialistas no corpo feminino e o aumento de publicações, especialmente das teses de doutoramento, percebe-se que o quadro da prática obstétrica e ginecológica nas últimas três décadas do século XIX havia mudado bastante em relação àquele tão criticado por Fernando Magalhães, ele mesmo formado na última década do século, tendo convivido com os mais famosos médicos de senhoras do Rio de Janeiro. Sem dúvida, contribuiu muito para esta mudança a edificação de um ambiente intelectual propício aos debates e à exposição das idéias, que contava com as associações médicas e as publicações, como a Gazeta Médica da Bahia e o Brazil Médico, e também os congressos, nos quais nossos obstetras e ginecologistas tinham a oportunidade de ouvir e de trocar experiências.

A atuação de médicos, como Werneck de Almeida, Rodrigues dos Santos, Rodrigues Lima, Oliveira Araújo, Climério de Oliveira, Fernando Magalhães, e parteiras, como Madame Durocher, que participou ativamente dos debates científicos, foi decisiva para a constituição da obstetrícia e da ginecologia no Brasil. Aqui, instituiu-se a prática de uma clínica que em nada diferia daquela praticada na França, Inglaterra ou na Alemanha, apesar da carência dos hospitais e da ausência de uma política de saúde voltada para a assistência materno-infantil. 
Se observarmos a bibliografia consultada e analisada por Fernando Magalhães (1922b), num total de 1.793 títulos, englobando livros, artigos, ensaios e teses, especialmente estas últimas, pode-se estabelecer a cronologia da constituição das duas especialidades e acompanhar as doutrinas seguidas e a evolução da prática da clínica obstétrica e ginecológica no Brasil. Os debates sobre temas polêmicos e a divulgação das observações clínicas presentes nesta vasta produção são indicativos não só da evolução das duas especialidades no Brasil, mas principalmente da construção do saber sobre o corpo feminino e das representações médicas a respeito da mulher.

\section{A Ciência da Mulher no Brasil: práticas e representações}

A produção do conhecimento obstétrico-ginecológico no Brasil não se deu unicamente nas faculdades de medicina ou por meio da publicação de livros e teses. Boa parte dos conhecimentos foi divulgada nas associações médicas e nos periódicos especializados e alguns casos mais polêmicos chegaram a freqüentar as páginas da imprensa diária, para desaprovação de alguns médicos, que não viam com bons olhos a transformação de casos clínicos em notícias ao alcance dos não-iniciados.

Apesar das dificuldades para se constituir a medicina da mulher no Brasil, temas comuns às duas especialidades acabaram por propiciar debates e mesmo por gerar polêmicas representativas do pensamento médico da época a respeito da profissão, de questões éticas e morais, das relações entre médicos e pacientes e, principalmente, das idéias a respeito de seu objeto comum: as mulheres. De acordo com a análise de José Leopoldo Antunes (1999), os debates que extrapolaram o meio médico e acadêmico são mais do que testemunhos da história do pensamento médico, constituindo um conjunto de textos exemplares do grau de intervenção médica na sociedade. Para o caso da obstetrícia e da ginecologia esta afirmação é bastante procedente. As questões polêmicas que envolveram os médicos são reveladoras da constituição de espaços e publicações que possibilitaram a emergência dos debates, dos saberes, da autoridade médica e das divergências entre os médicos. Essas polêmicas também fornecem informações sobre o grau de intervenção nos corpos femininos e sua transformação em 'casos', em 'peças' passíveis de observação, descrição, análise e comparação, origem e destino do saber médico. 
A divulgação dos conhecimentos e dos casos polêmicos foi incentivada com a criação de publicações especializadas, como vimos anteriormente, no entanto, somente em 1907 as especialidades de obstetrícia e ginecologia conquistaram um espaço exclusivo de produção e divulgação de conhecimentos, exposição de idéias, defesa de posições a respeito de doutrinas e debates de temas polêmicos. Trata-se da Revista de Ginecologia e Obstetrícia do Rio de Janeiro (RGO) idealizada pelo Dr. Alberto Ribeiro de Oliveira Motta, que se tornou posteriormente o órgão oficial da Sociedade de Obstetrícia e de Ginecologia do Brasil, fundada em 1921, com sede no Rio de Janeiro.

A revista surgiu com o objetivo de promover as duas especialidades no Brasil, bem como de incentivar o desenvolvimento da pediatria, que foi incorporada ao nome da revista em 1919. Geralmente havia dois ou três artigos tratando de temas relativos à clínica e à cirurgia, resenhas e a seção Petit Revue com resumos em francês dos artigos publicados para informar seu conteúdo aos leitores estrangeiros. Sete anos depois de sua criação, a lista de colaboradores da RGO já contava com 37 especialistas entre brasileiros e estrangeiros, o que demonstra como esta publicação se tornou um importante e respeitado veículo de divulgação do saber obstétrico e ginecológico na América do Sul. Durante a década de 20 do século passado, quando a assistência obstétrica começou a ser prestada nas maternidades, a revista passou a publicar o Registro da Clínica Obstétrica da Faculdade de Medicina do Rio de Janeiro, divulgando todos os atendimentos e procedimentos médico-cirúrgicos, bem como informações detalhadas a respeito das parturientes.

No entanto, casos polêmicos envolvendo a ginecologia e a obstetrícia já tinham mobilizado os médicos e a opinião pública em épocas anteriores, como foi o primeiro parto da Princesa Isabel, atendida pelo Dr. Feijó, cujo feto foi craniotomizado. Este parto malogrado alcançou notoriedade com a circulação de um folheto assinado por Carolino dos Santos, pseudônimo do Dr. Nunes Garcia, médico parteiro que acusou o Dr. Feijó e seus assistentes de imperícia. O trauma vivido pela princesa deve ter sido de tal magnitude que no seu segundo parto foi chamado o obstetra francês Dr. Depaul para atendê-la, o que gerou reações entre os médicos brasileiros, para quem a chegada de um médico estrangeiro foi sentida como uma afronta. O Dr. Fernando Magalhães (1922b) conta que, após usar o fórceps em um parto difícil, mas bem-sucedido, Depaul foi requisitado para atender 
outras mulheres, ganhando bastante dinheiro durante sua permanência na Corte, para desagrado dos médicos da terra.

Embora esse caso tenha gerado reações e trocas de acusações, pois, afinal, envolveu um médico com a reputação do Dr. Feijó, o caso que mais polêmica suscitou ocorreu em Salvador em 1878 e ficou conhecido como 'Questão Braga'. Geralmente associado à medicina legal por tratar-se de um caso de perícia, é uma amostra das relações entre os saberes das especialidades, das divergências médicas e, principalmente, da objetivação do corpo feminino pelo saber médico. A Questão Braga foi, na verdade, um grande escândalo que chegou às páginas dos jornais, sendo comentada tanto por especialistas quanto por pessoas leigas, mas atentas aos escândalos envolvendo famílias ricas.

Em uma avaliação posterior ao caso, o legista Afrânio Peixoto comenta que situações como a que ocorreu em Salvador deviam servir de lição para os médicos, que precisavam evitar a emissão de laudos àqueles que não fossem legistas a fim de não incorrer em erros como incorreram os médicos baianos: "Os peritos - homens de grande valor, mas não médicos legistas - erraram, porque não souberam ver, não souberam dizer o que viram e nomearam e classificaram mal, dando um resultado errôneo e insanável à perícia" (Peixoto, 1946: 63). Vejamos o que os médicos baianos não souberam ver, nominar e classificar.

Em 30 de novembro de 1878, o professor substituto da Faculdade de Medicina da Bahia e parteiro, Dr. José Pedro de Sousa Braga, com 33 anos de idade, casou-se com a jovem Cândida Augusta Ferreira, de 18 anos, filha do rico comerciante Manuel Alves Ferreira. Para espanto dos seus sogros, no dia seguinte à noite de núpcias, Dr. Braga foi entregar a esposa de volta aos seus pais, pois descobrira que ela não era mais virgem, fato este que consistia no 'erro essencial de pessoa', uma situação que tornava legítimo ao marido pedir a anulação do casamento. A família de Cândida chamou dois médicos para examiná-la, sendo um deles o Barão de Itapoan, professor de partos da Faculdade de Medicina. Ambos atestaram que o defloramento ocorrera recentemente, o que levou a família requerer junto ao chefe da polícia um exame médico-legal para provar a honestidade de Cândida. Foi composta uma comissão com cinco médicos, responsáveis pelo exame e pelo laudo que confirmava ter ocorrido o defloramento na noite de núpcias.

O Dr. Braga foi questionado pelo chefe de polícia a respeito de suas acusações, ao que respondeu dizendo haver suspeitado da esposa devido a 
alguns sinais como a flacidez dos seios em uma moça de 18 anos e o estado dos órgãos genitais externos, que, segundo sua apreciação, não eram próprios ao estado de uma 'vulva virginal'. Em seguida, o 'marido' procurou fazer exames, como o toque vaginal, concluindo que não havia a presença de hímen. Após o exame médico nupcial, consumou o ato e obteve a confissão da esposa de que tivera encontros amorosos antes do casamento.

Insatisfeito com o resultado da perícia que inocentava sua esposa, o Dr. Braga enviou o laudo para seis especialistas fora da Bahia, sendo eles: o Dr. Souza Lima, catedrático de medicina legal, e o Dr. Luiz da Cunha Feijó Filho, catedrático de obstetrícia, ambos do Rio de Janeiro; o Dr. Filipe Simões e o Dr. Lourenço de Almeida Azevedo, respectivamente professores de medicina legal e de obstetrícia da Universidade de Coimbra; o legista Paul Brouardel e o obstetra já conhecido pelos brasileiros, Dr. Depaul, ambos da Faculdade de Medicina de Paris. Devido ao uso de um termo inadequado pelos peritos baianos, os pareceres encomendados pelo Dr. Braga foram de conclusão que o defloramento era antigo (Peixoto, 1946).

A reputação de Cândida parece ter sido restabelecida, pois o laudo dos médicos baianos foi favorável a ela e, segundo Dinorah Castro (1996), pesava sobre o Dr. Braga a suspeita de ter agido de má-fé, movido por interesses econômicos, ficando a opinião pública contra ele.

O que sobressai dessa história em que se misturaram elementos de violência, reputações em jogo, conhecimentos médicos e a fria técnica dos exames periciais é a transformação de Cândida em um corpo passivo, examinável, reduzida aos detalhes minuciosos de seus órgãos genitais. O que mais impressiona é que o exame começou na própria noite de núpcias com o Dr. Braga agindo como médico e marido ao mesmo tempo, comportamento este que foi severamente condenado pela avaliação do Dr. Afrânio Peixoto, para quem as observações do Dr. Braga depunham contra ele como médico e como homem, por ter agido como agiu, expondo seu desconhecimento do corpo feminino e sua leviandade ao expor a questão da forma como o fez. Muito embora este caso tenha sido o mais comentado, não era incomum, segundo Peixoto, sendo até numerosos, o que exigia a intervenção de médicos legistas e não de obstetras pouco informados sobre detalhes do corpo feminino como a diversidade de tipos de hímens. ${ }^{9}$

Outro aspecto importante a salientar é a esfera das competências. Legistas e obstetras disputaram para estabelecer a verdade sobre o mesmo campo de fenômenos, expondo diferentes métodos de investigação. Na época 
em que se deu a 'Questão Braga', a medicina legal estava começando a se constituir como especialidade no Brasil. Com a 'Questão Braga', obstetras e legistas trabalharam juntos, como se pode observar pela composição das comissões, mas as conclusões foram diferentes, apontando para divergências a respeito dos métodos de observação e críticas, especialmente dos europeus, quanto à terminologia usada pelos médicos baianos. Embora os obstetras pudessem atuar como peritos, a questão que começava a ser formulada com o episódio foi que deveriam fazê-lo a partir das teorias e dos métodos da medicina legal.

De qualquer forma, este caso mostra como a medicina legal também foi outra especialidade que teve no corpo feminino um dos seus objetos privilegiados, especialmente no que se refere à sexualidade, ao tratar de assuntos como estupro, defloramento, aborto, infanticídio e os efeitos psíquicos da menstruação. Para as mulheres envolvidas em processos sobre tais questões, o laudo do legista tinha uma importância considerável; afinal, era o testemunho do olhar objetivo e científico que decidia sobre a reputação das mulheres, desempenhando um importante papel de mediador autorizado nos conflitos de gênero arbitrados pela justiça.

Outro caso rumoroso que envolveu os obstetras e ginecologistas brasileiros foi a discussão em torno da esterilização da mulher que teve origem na divulgação, nos jornais do Rio de Janeiro em 1893, de um 'processo secreto' mediante o qual o ginecologista italiano Abel Parente garantia excelentes resultados. ${ }^{10}$

Os anúncios geraram uma reação imediata por parte dos médicos obstetras e ginecologistas que iniciaram uma verdadeira campanha contra o médico italiano e o seu invento, por intermédio das associações médicas, resultando num inquérito policial. Os mais importantes e respeitados especialistas brasileiros vieram a público externar sua rejeição à idéia de uma cirurgia que esterilizasse as mulheres, começando pelo Dr. José Rodrigues dos Santos (1893), que escreveu uma monografia sobre o assunto, apresentada à Academia Nacional de Medicina, cujo título foi formulado como uma pergunta: Scientificamente é Possível a Esterilização da Mulher? $\mathrm{O}$ autor responde negativamente à questão, dizendo: "Perante a natureza, perante a moral, perante a sciencia e às minhas convicções, declaro que não há um só meio capaz de conseguir este fim sem atentar contra os costumes e a moralidade pública, ou sem criar estados mórbidos". 
Para Rodrigues dos Santos, o recurso a uma cirurgia esterilizadora era algo inaceitável, pois a medicina não podia privar a mulher dos órgãos que a natureza havia lhe dado para exercer uma função ao mesmo tempo natural, moral e social. Como exemplo dos abusos da cirurgia ginecológica, Rodrigues dos Santos (1893) cita o caso de um médico inglês que realizou várias clitoridectomias por acreditar estar curando a histeria. Da mesma forma, Rodrigues dos Santos condenava com veemência a esterilização, pois acreditava que a ciência teria seus fins desviados para outros misteres, chocando-se contra a moral e os bons costumes, ao degradar a mulher, a família e a sociedade.

Esta era também a opinião de seus colegas que se envolveram no caso do Dr. Abel Parente, entre eles o Dr. Werneck de Almeida, um dos médicos ouvidos no inquérito. ${ }^{11}$ Seu depoimento é uma síntese do pensamento médico da época a respeito de temas como o exercício da medicina, a ética e as regras que deveriam pautar a publicação dos conhecimentos médicos. Werneck começou seu depoimento desqualificando o médico inventor, dizendo que nada de sério nem de científico havia no seu processo, apenas interesses pecuniários.

Uma prova incontestável da má-fé de Parente era o caráter secreto de seu invento, furtando-se à crítica e ao debate com seus pares. Para Werneck e seus colegas, o processo esterilizador não tinha outro objetivo a não ser a contracepção, e este era o alvo principal de suas críticas. Do corpo feminino para o corpo da pátria, os médicos envolvidos na polêmica logo alertaram para a ameaça da depopulação. Werneck de Almeida admitia que a cirurgia esterilizadora talvez fosse uma opção para os países com excesso de população, onde a fome e todos os tipos de problemas de saúde atingiam as classes pobres, mas não para um país como o Brasil,

país novo e despovoado, em que a vida é fácil (...). Sem base, nem fundamento científico, tal descoberta é um ataque direto às leis mais comezinhas do decoro e da dignidade profissional, um atentado contra a moralidade e o futuro do nosso país e um crime de lesa-humanidade. ${ }^{12}$

Werneck de Almeida pediu pareceres de médicos estrangeiros de reconhecida fama a respeito do caso, os quais se opuseram veementemente, engrossando o coro dos médicos brasileiros que acusaram Parente de imoral e charlatão. Apesar das reações e da dimensão escandalosa que o caso teve, o inquérito foi encerrado a pedido do Diretor do Instituto Sanitário Federal, Dr. Francisco de Castro, um dos defensores de Abel Parente. 
Em 1901, o assunto volta a movimentar o meio médico do Rio de Janeiro e a freqüentar as páginas dos jornais, tornando-se novamente um caso de polícia, mas desta vez motivado pela denúncia de que o 'invento' do Dr. Parente teria levado uma mulher à loucura. Desta vez, o médico foi condenado, mas devido a vários recursos, acabou por não cumprir a pena de 15 dias de reclusão, pois o crime prescrevera, o que levou o Dr. Barata Ribeiro a expressar, em discurso na Academia Nacional de Medicina, o desagrado da classe médica, que lamentava "ver a família brasileira abandonada à petulância obscena dos exploradores (apud Magalhães, 1922b: 160).

Apesar da condenação e do escândalo, o tema da esterilização da mulher não saiu de cena, pois em 1902, um ano após a condenação de Parente, Alberto R. de Oliveira Motta apresentou como tese de doutoramento o trabalho Prophylaxia anti-concepcional de Kehrer e Dührssen (apud Magalhães, 1922b), no qual defendia a processo esterilizador de Parente. A congregação rejeitou a tese e em 1903 Oliveira Motta escreveu a tese O keleno em obstetrícia (apud Magalhães, 1922b), conseguindo, finalmente, obter o título de doutor em medicina. Este episódio é ainda mais interessante do que o caso do Dr. Parente se levarmos em consideração que quatro anos depois Oliveira Motta fundava a RGO - na qual foi publicado o artigo de Hugo Werneck, criticando-o como 'defensor do esterilizador' e, o que é mais irônico, em 1908 assumia a vaga do Dr. Werneck de Almeida - o mais aguerrido opositor de Abel Parente e da esterilização da mulher para fins contraceptivos - na Academia Nacional de Medicina. ${ }^{13}$

O assunto continuou sendo abordado ocasionalmente em teses médicas nas quais a questão adquiriu um tom cada vez mais ideológico, ficando em segundo plano considerações a respeito dos efeitos de uma cirurgia irreversível para a saúde física e psicológica das mulheres. Na época em que o debate em torno do método de Abel Parente começou, a reação dos médicos foi direcionada ao comportamento considerado anti-profissional do médico, que anunciou pela imprensa um método contraceptivo e não o expôs nos espaços exclusivos que haviam para estes fins. Era uma atitude que contrariava a ética profissional, baseada na discrição e na partilha de conhecimentos e novas terapêuticas, fosse através de congressos ou conferências, fosse nas publicações especializadas. Mesmo assim já se percebe o argumento político, baseado no valor da população como riqueza da nação, que fundamentava a rejeição aos métodos contraceptivos. 
Esse argumento passou a ser mais importante no discurso médico à medida que se acirravam as discussões e as diferenças entre os neomalthusianos e os eugenistas no início do século XX, envolvendo médicos, filantropos, religiosos e cientistas de diferentes países. Os neomalthusianos defendiam a divulgação de métodos contraceptivos como forma eficaz de combater o excesso populacional e a pobreza; já os eugenistas tinham uma visão diferenciada desta questão, defendendo uma limitação seletiva do crescimento populacional, temendo que a contracepção entre as classes médias e altas se tornasse um fator de deterioração da raça. O discurso eugenista foi particularmente sensível na Inglaterra e na França, onde motivações de ordem política e social levaram os médicos a adotar uma postura contrária aos métodos contraceptivos generalizados para todas as classes sociais. ${ }^{14}$

Entende-se melhor, portanto, porque o Dr. Werneck de Almeida qualificou a cirurgia esterilizadora de atentado contra o futuro do país e crime de lesa-humanidade, praticamente não se referindo ao significado da cirurgia para as mulheres. Ele temia que procedimentos como esse acabassem por se generalizar, escapando do controle do establishment médico, tornando a contracepção e o aborto práticas disseminadas entre a população feminina.

À medida que o século XX avançava e a doutrina eugenista atraía defensores no Brasil, o tom dos discursos foi mudando, incorporando à problemática da depopulação a questão racial e social. Para os médicos, não havia sentido algum aderir a teorias neomalthusianas em um país de vasta extensão territorial e com as decantadas riquezas do Brasil. Alguns, como o Dr. Gastão Guimarães, mostravam-se céticos com a política imigratória do governo brasileiro, temendo uma futura desagregação territorial. Guimarães mostrou-se um natalista deliberado ao defender a idéia de que antes de incentivar a vinda de estrangeiros, o governo devia incentivar o crescimento populacional.

Nós pensamos que o governo deveria instituir prêmios, recompensas para os nacionais que tivessem um certo número de filhos, de modo que, ao lado das beneficências produzidas por uma imigração bem orientada e bem cuidada, os nossos casais pudessem concorrer muito para o aumento da população do nosso país. (Guimarães, 1912: 38)

Mas o alvo das censuras não eram somente o governo e nem os 'esterilizadores', como Abel Parente, mas também as mulheres. Teses como a de Guimarães e principalmente as que tratavam da higiene na gravidez 
atacavam duramente as mulheres que não queriam ter filhos ou que procuravam obstar a Natureza tendo poucos filhos. Nada era mais condenável, com exceção do aborto, do que evitar a gravidez, impedir o nascimento dos filhos, opor obstáculos ao exercício constante da maternidade, a não ser que a mulher tivesse uma saúde muito frágil.

Guimarães dá como exemplo positivo os pobres e negros da Bahia com o objetivo de elogiar suas famílias prolíficas, reavivando uma crença bastante generalizada de que os filhos são a alegria dos pobres:

Eles sentem um orgulho natural e ilimitado quando reparam e reflexionam sobre a [sua] fecundidade que classificam de bendita e de consoladora. Trabalham, duplicam as forças, curvam-se sob o peso de um trabalho rude e fadigante, envelhecem rapidamente, mas bendizem sempre aquela filharada alegre e sadia que será seu eterno tesouro, a sua eterna alegria. Da simplicidade e da naturalidade de suas práticas amorosas nascem filhos robustos e sadios, portadores de uma saúde potente, fruidores de um bem estar absoluto. (Guimarães, 1912: 32)

Essa visão idílica da pobreza prolífica e saudável era parte fundamental de um discurso construído sobre a oposição entre o estado natural dos negros e dos pobres e os males da civilização que seduziam especialmente as mulheres brancas e de posses, vaidosas e egoístas, que não queriam engravidar nem - crime maior - amamentar, para não deformar seus corpos. Em uma inversão do discurso médico, os pobres e negros deviam servir de exemplo para as classes brancas e ricas do Brasil que não queriam ou não se empenhavam suficientemente em ter filhos.

Esse discurso procurava disseminar, desde meados do século XIX, a ideologia da maternidade, valorizando a mulher-mãe, dedicando-se a estudar seu corpo e o processo do parto, produzindo o que poderíamos chamar de uma pastoral moderna, consolidada na Ciência, mas com o aval da religião. Esta ideologia transformou a maternidade em um dever não só para com a família, mas para com o Estado, para esta família extensa e sentimental que é a pátria. Os médicos acenavam com promessas de felicidade, de realização pessoal na criação dos filhos e de elevação moral da mulher, algo que tanto o romantismo quanto o positivismo sancionaram ao idealizar a maternidade e entronizar a mãe no altar do lar. ${ }^{15}$

Dessa forma, o apelo que Guimarães fez às mulheres na conclusão de sua tese é representativo desta construção ideológica da maternidade e procura mostrar que as transformações do corpo materno não deviam ser 
recebidas como se fossem o anúncio do fim da juventude e da beleza, mas sim os sinais de um outro tipo de beleza e de felicidade que só as mulheres que passavam pela experiência da maternidade podiam conhecer e usufruir:

Procriai mulheres, porque a vossa beleza ressurgirá no corpo de vossos filhos; os vossos cabelos irão novamente aureolar as vossas frontes; as vossas perdidas curvas reaparecerão; os vossos sorrisos serão alegres; os vossos olhos se encherão de uma luz mais pura e mais penetrante; o sangue destruirá o roxo de vossas olheiras; o colorido desmanchará as manchas de vossas faces; os vossos ventres se retrairão; tudo desaparecerá e então sereis as mesmas mulheres mais respeitadas ainda, porque embalareis em vossos braços o petiz sorridente e vivo, enquanto as vossas almas se embalarão dentro de vós mesmas. (Guimarães, 1912: 46)

É interessante observar o uso narrativo que o autor faz dos tributos que a Natureza cobra do corpo das mulheres para que elas sejam mães. Tanto o autor quanto seus colegas de profissão sabiam que nem sempre a gravidez era um processo tranqüilo e que, geralmente, produzia transformações que afetavam bastante a beleza e que podiam ser irreversíveis, como também sabiam as mulheres. O discurso médico reconhece estes problemas (acúmulo de gordura, olheiras, manchas), só que reforça a transitoriedade dos mesmos e a promessa de uma nova beleza e de uma nova dignidade: a beleza da Madona, tão reproduzida pelas imagens da 'Virgem com o Menino', desse modo, a educação das mulheres estava voltada desde a infância para a sua futura missão.

Os médicos cumpriram um novo papel no conjunto bastante heterogêneo de discursos que louvavam a maternidade e a mulher-mãe. O lado 'positivo' da natureza feminina era exaltado tanto por homens cultos, como é o caso dos médicos, quanto pelas próprias mulheres que defendiam os direitos civis, como mostra Anna Davin (1978), ao analisar a participação feminina em sociedades de voluntários para educar as mulheres das classes trabalhadoras a bem exercer suas funções maternas no início do século XX na Inglaterra. Portanto, a elevação moral da mulhermãe e a exaltação da beleza do corpo materno são elementos do mesmo mecanismo ideológico acionado ao longo do século XIX, no qual as engrenagens de gênero eram fundamentais para o funcionamento de uma sociedade baseada na divisão sexual do trabalho.

Os médicos brasileiros estavam convictos do seu papel de orientadores e protetores das mulheres para que elas cumprissem sua função natural e social. Assim, procuraram conhecer o corpo feminino e suas transformações, 
ampliando paulatinamente sua intervenção durante a gravidez até conseguirem conquistar a confiança das mulheres, transformando o parto, durante a primeira metade do século XX, em um evento hospitalar.

O início desta incursão pelo corpo feminino deu-se com os estudos sobre a gravidez. Durante o século XIX e inícios do XX foram muito numerosas as teses médicas que trataram deste tema, especialmente dos métodos de diagnóstico, por tratar-se de um ponto obscuro da clínica obstétrica, tendo em vista a falta de prática dos médicos e as dificuldades para diferenciar estados gravídicos iniciais de outros problemas de natureza ginecológica.

A necessidade de desenvolver métodos seguros de diagnóstico da gravidez não atendia somente ao desejo das mulheres casadas em querer saber se realmente haviam engravidado, mas tinham implicações maiores, como a elaboração de laudos periciais em processos de defloramento, acusação de adultério ou de averiguação da responsabilidade de mulheres acusadas de crimes. Portanto, o estabelecimento do diagnóstico da gravidez tinha implicações sociais e morais que exigiam dos médicos muita responsabilidade e conhecimento das técnicas de investigação do corpo feminino.

Observando o conjunto de teses que abordam o assunto, percebe-se que as dificuldades levantadas pelos autores são, na sua maioria, colocadas pelas mulheres. Como definiu Fernando Magalhães (1933: 24) no seu livro sobre as relações entre a obstetrícia e a lei, "a prenhez acusa, justifica e absolve", ou seja, em se tratando de um assunto com tantas implicações como a gravidez, o médico devia cercar-se de cuidados para não ser enganado pelas informações prestadas pelas mulheres, pois o diagnóstico poderia denunciar um comportamento condenável ou frustrar o desejo acalentado de ser mãe.

Como vimos anteriormente, o Dr. Magalhães alertava os médicos para o fato de que as mulheres enganavam e se deixavam enganar. Entre estas estavam as mulheres que desejavam muito ser mães e relatavam aos médicos ou às parteiras todos os sintomas da gravidez e outras que teriam cometido algum 'coito ilícito e incompleto' e, de tanto temer a gravidez, acreditavam estar grávidas também desenvolvendo os sintomas. Por fim, na classificação das 'enganadas' estavam as neuropatas, mulheres que sofriam algum tipo de tumor - que por inexperiência do médico fora diagnosticado como gravidez - e passaram a desenvolver os sintomas. Já aquelas que enganavam tinham interesses inconfessáveis, ora para esconder uma gravidez indesejada, ora para simulá-la com finalidade de imputar a paternidade a alguém, ou mesmo para interromper a gravidez, simulando uma doença ginecológica. 
Diante de tantas dificuldades colocadas pelas mulheres, como os médicos deviam agir? Em primeiro lugar, procurando estabelecer a verdade, procurá-la em meio à confusão subjetiva das pacientes. Em segundo lugar, seguir métodos clínicos desenvolvidos pelas autoridades médicas obstétricas, baseados na investigação minuciosa dos sinais, pela combinação do tato e do olhar, pelo menos até que novos métodos fossem desenvolvidos, como os exames laboratoriais.

O estabelecimento do diagnóstico da gravidez aproximou obstetras e legistas, especialmente no que diz respeito ao princípio investigativo. Magalhães (1933) comenta que o obstetra forense devia se basear no princípio visum et repertum, ou seja, no olhar médico e no relato da pessoa examinada. No entanto, tendo em vista que as mulheres "enganam, enganam-se e são enganadas" (Magalhães, 1933: 36), o médico devia se apoiar mais no visum do que no repertum. O clínico tinha de seguir o mesmo conselho e se fiar mais na informação obtida pelo exame físico. Este era dividido em dois momentos: a inspeção do corpo e o exame ginecológico, que seguia exatamente as orientações dos tratados de obstetrícia.

Estabelecido o diagnóstico, fosse pelo médico ou pela parteira, dificilmente havia um acompanhamento da gestação, pois, na época, não existia o conceito de pré-natal, e as mulheres só procuravam a parteira ou o médico no momento de dar à luz. Entretanto, já no final do século XIX percebe-se uma alteração nos discursos médicos, com a recomendação de que as mulheres deviam submeter-se a exames médicos com certa freqüência durante toda a gestação. Com esta recomendação, os médicos procuravam não só se certificar quanto às condições do parto, mas convencer as mulheres a aceitar as regras por eles estabelecidas sobre o que era melhor para elas e os bebês, iniciando-se, assim, o processo de medicalização da gravidez, do parto e do puerpério.

Boa parte desta verdadeira pedagogia da maternidade não saiu do papel, pois a mudança de comportamento em relação à gravidez e ao parto não ocorreu como os médicos desejavam porque a maior parte das mulheres brasileiras dificilmente podia seguir à risca as prescrições que os médicos recomendavam. As teses tinham como modelo as mulheres brancas ricas ou de classe média que podiam se dar ao luxo de seguir dietas especiais, fazer repouso e mesmo pagar consultas médicas. Foi para elas que os médicos se voltaram, tentando convencê-las de que seus conselhos, se seguidos, podiam resultar em uma gestação mais tranqüila, em um parto controlado e em um bebê saudável, evidenciando o efeito da classe social 
na percepção dos médicos a respeito de suas pacientes. De uma forma geral, se tomadas em conjunto, nas obras de obstetrícia e de higiene há uma categoria universal - a Mulher -, mas ao lidar com a normatização das condutas, ao prescrever cuidados e tratamentos, seus autores têm como referência as condições de vida das mulheres burguesas.

As teses de higiene na gravidez são exemplares da mudança do discurso médico em relação às grávidas e ao papel dos médicos no que devia ser uma 'vigilância científica' das mulheres de todas as classes sociais, segundo expressão encontrada numa destas teses (Ferreira, 1906). Algumas se restringiam às regras de higiene, mas já havia, no início do século XX, uma orientação eugênica no tratamento do assunto, justificando a intervenção médica com finalidade preventiva para evitar a degeneração da raça e o enfraquecimento da pátria. Também percebe-se um crescente interesse pelo feto, pois até então a mulher era o objeto exclusivo da obstetrícia. O discurso eugenista dos obstetras do início do século XX chamava cada vez mais a atenção para a saúde do feto, vindo a ser um importante elemento na defesa da assistência médico-hospitalar às mulheres.

As teses e os artigos produzidos a respeito do parto revelam como a obstetrícia no Brasil e também a ginecologia foram conservadoras. Esta palavra tem aqui o sentido de preservar, em oposição aos excessos intervencionistas. Embora se conhecessem e empregassem os métodos intervencionistas, como o fórceps, as versões, as embriotomias e, por fim, a cesariana, os obstetras brasileiros mostraram-se cautelosos no momento de intervir, sendo muito criticados aqueles que abusavam da força e de práticas mutiladoras, como a craniotomia em feto vivo, prática cruel e extremamente traumatizante para a mulher, ainda realizada no final do século XIX.

O nível dos conhecimentos sobre o parto revela atualização dos autores das teses a respeito do assunto, mesmo que fosse somente na teoria. Pelas referências à prática dos médicos, todas as inovações da ciência obstétrica produzidas ao longo do século XIX foram imediatamente adotadas no Brasil, como o clorofórmio, por exemplo, introduzido como anestésico no parto em 1848 pelo Dr. Rodrigo de Bivar, parteiro do Hospital da Santa Casa do Rio de Janeiro. Enquanto na Inglaterra e na França a anestesia obstétrica encontrou forte oposição por parte dos médicos e dos religiosos, no Brasil, os testemunhos apontam para uma crescente aceitação, tanto por parte dos médicos quanto das parturientes, que pediam para serem cloroformizadas. 
Em sua tese sobre o assunto, o Dr. José Cordeiro (1876: 1) explica que o uso de anestésicos no parto tornara-se imprescindível e "uma das práticas mais sublimes da obstetrícia", devido às transformações sofridas pelo corpo da mulher civilizada. Seu argumento baseia-se na crença de que as fêmeas animais e as mulheres dos povos primitivos não tinham partos dolorosos porque as primeiras viviam no estado da natureza e as segundas muito próximas a este estado. Já as mulheres das sociedades modernas sentiam dores terríveis no parto devido a vários fatores como a vida sedentária, o luxo e os maus hábitos higiênicos que as afastavam da natureza, predispondo-as a partos dolorosos. Cita como exemplo desta dicotomia as diferenças entre as mulheres da Corte e as das províncias, dizendo que entre as primeiras o parto era excessivamente doloroso, a convalescença longa e o abalo nervoso considerável, enquanto as mulheres que viviam longe do burburinho e das fortes impressões da Corte se restabeleciam rápido e o parto não era laborioso.

Discussões como essa eram bastante comuns entre os obstetras, apontando para os efeitos perniciosos da civilização para o corpo feminino, o que reforçava seu discurso normativo sobre a gravidez e o parto. Quanto à intervenção no momento do parto, os médicos brasileiros lançaram mão do instrumental obstétrico disponível na época, mas os professores alertavam seus alunos para os riscos do excesso intervencionista. Entre eles destaca-se Fernando Magalhães, considerado o nome mais importante da obstetrícia brasileira das primeiras décadas do século XX.

Em aula de encerramento de curso, proferida em 1916, Magalhães conseguiu expor aos doutorandos um verdadeiro programa de clínica, resumindo as principais linhas da escola obstétrica brasileira. Seu princípio era 'nem o máximo, nem o mínimo', ou seja, o obstetra não devia agir precipitadamente, prejudicando o curso normal da natureza, nem eximirse de agir, deixando de corrigir a natureza quando esta se desviasse de seu caminho. Para Magalhães, o bom obstetra tinha de saber esperar para agir, ter boa cultura, saber observar e ser disciplinado. Nada era mais condenável do que o uso da força, já que o próprio parto era um exercício de forças naturais que agiam para que o feto se desvencilhasse do corpo materno. $\mathrm{Na}$ sua explicação de como devia agir um bom parteiro, ele condenava o uso indiscriminado de drogas para acelerar o parto, mas seu principal alvo de críticas foi o uso da força instrumental ou operatória. Nesse sentido, a obstetrícia brasileira se diferenciava de algumas escolas mais 
intervencionistas que pregavam o uso do fórceps em qualquer situação de distocia, o que quase sempre resultava em lesões muitas vezes irreversíveis para o feto e em muito sofrimento para a parturiente.

Os obstetras brasileiros não parecem ter seguido a linha intervencionista sem críticas, como demonstra a seguinte passagem da aula de Magalhães:

Esta obstetrícia que se exibe pelo máximo de trabalho penoso e contundente, que deixa de si a lembrança da ruína, que se resolve no esforço desmedido e traumatizante, que mutila os atributos da feminilidade, que arranca do útero o feto ferido e deformado, prejudicando a doente, não pode ser representativa do préstimo profissional, rústico e primitivo se só puder valer pela depredação. (Magalhães, 1922a: 468)

Essa posição cautelosa e comedida defendida pelo médico mais representativo da obstetrícia moderna brasileira pode ser a explicação para a tolerância dos médicos com as parteiras no Brasil. Magalhães chegou a afirmar que o exercício leigo da obstetrícia era menos pernicioso do que a "ação exorbitante ou incapaz do diplomado" (Magalhães, 1933: 9), desde que as parteiras se limitassem a consolar as parturientes e a exercer uma vigilância cautelosa, sem intervir, nem receitar. Nos países onde a obstetrícia desenvolveu-se reconhecidamente como intervencionista, geralmente a luta contra as parteiras foi mais encarniçada, como é o caso dos Estados Unidos (Ehrenreich \& English, 1973).

O conjunto das teses médicas que tratam do parto natural ou do laborioso demonstra uma atitude que poderíamos definir como 'expectação armada', ou seja, os instrumentos e as técnicas que permitiam intervir em partos complicados e de risco eram conhecidos e razoavelmente colocados em prática. Mas não houve, por parte das duas mais antigas escolas de obstetrícia do país, uma orientação intervencionista, fundada exclusivamente na crença da supremacia da tecnologia e da destreza do obstetra ou cirurgião. De acordo com Fernando Magalhães, o obstetra devia abandonar o uso da força em favor do sentimento humanitário, resgatando as origens da obstetrícia, como um ofício manual e de exercício da paciência e da sabedoria: "Só o aforismo da arte vencedora contra a força repudiada poderá garantir a vossa tranquilidade" (Magalhães, 1922a: 472).

Esta orientação não significava, contudo, que o médico desconhecesse as operações obstétricas e a cirurgia, em especial a cesariana. Magalhães foi um dos maiores divulgadores desta cirurgia no Brasil, desenvolvendo 
métodos próprios para realizá-la. Considerada por muito tempo como uma solução para salvar apenas a criança, sendo realizada em mulheres mortas, a cesariana foi reabilitada no final do século XIX graças aos métodos antisépticos e ao desenvolvimento de técnicas que afastavam a terrível ameaça de morte por hemorragia.

No entanto, alguns testemunhos indicam que a cesariana demorou para se vulgarizar na prática cirúrgica dos obstetras brasileiros, especialmente nas cidades do interior. O filho do Dr. Werneck de Almeida, Hugo Werneck, também obstetra e ginecologista, comenta que apesar dos sucessos da cesariana, a embriotomia era ainda muito praticada no país no início do século XX. Tal fato se dava devido à carência das clínicas e dos hospitais que não tinham instalações adequadas, nem auxiliares treinados para realizar uma operação como a cesariana.

Hugo Werneck aponta para o que ele e seus colegas consideravam um problema mais grave do que a prática leiga das parteiras: o exercício da medicina por médicos 'enciclopédicos', que não tinham formação adequada, nem educação cirúrgica em obstetrícia. Da mesma forma que Magalhães, ele defendia uma orientação racional para a cirurgia obstétrica, fundada em critérios rigorosos para evitar colocar a mulher em situações de risco que podiam ser contornadas com métodos mais conservadores, como a episiotomia ou a sinfisiotomia, embora esta última pudesse deixar seqüelas muito dolorosas para a mulher.

De uma forma geral, os médicos de senhoras no Brasil não foram adeptos da chamada medicina heróica ou, como preferem as autoras feministas, do uso de terapias punitivas. Pelo contrário, o que se percebe é que, na prática, a atitude dos médicos brasileiros em relação às mulheres foi pautada pelo comedimento, não havendo espaço para a divulgação de práticas condenáveis, como a clitoridectomia, tratamentos químicos, contenção de movimentos ou dietas rigorosas que mais serviam para debilitar e dobrar a vontade das mulheres do que para produzir a cura de doenças 'encontradas' pelos médicos. Provavelmente isto se deva ao fato de que a misoginia no Brasil nunca foi tão forte quanto nos Estados Unidos, onde os médicos tiveram um importante papel na condenação dos direitos civis para as mulheres, bem como na experimentação de terapêuticas mais agressivas. Os médicos brasileiros conheciam e defendiam as principais teorias que relegavam as mulheres à condição de cidadãs de segunda categoria, devido à determinação do corpo sobre o comportamento. No entanto, há uma diferença muito 
grande entre aceitar os princípios segregacionistas de gênero e ser um misógino, tanto na reação a qualquer princípio igualitário quanto na adoção de práticas médicas punitivas. Neste sentido, os médicos obstetras e

ginecologistas brasileiros se pautaram por uma ética humanista, estando mais próximos de algumas correntes médicas francesas e inglesas avessas ao intervencionismo excessivo.

A produção do conhecimento sobre o corpo feminino no Brasil se acentuou a partir do momento em que foram criadas instituições médicohospitalares que forneceram as condições necessárias para o exercício da clínica e da cirurgia, para o ensino prático e, posteriormente, para o desenvolvimento de pesquisas científicas. Com a campanha movida em favor da assistência social à maternidade e a construção de espaços hospitalares específicos para o atendimento obstétrico e ginecológico, iniciou-se efetivamente o processo de medicalização do corpo feminino no Brasil.

\section{As Maternidades e a Assistência Médica às Mulheres}

Nas últimas duas décadas do século XIX, o meio médico europeu foi tomado pela discussão a respeito do atendimento hospitalar e da assistência filantrópica às mulheres pobres durante a gravidez, o momento do parto e o puerpério. Desde o final do século XVIII, alguns hospitais haviam reservado enfermarias ou mesmo criado maternidades com esta finalidade, mas estes espaços não gozavam de boa fama e eram vistos pelas mulheres como o último recurso. Criados em uma época em que a obstetrícia ensaiava seus primeiros passos em direção à especialidade, nestes hospitais não havia nenhum tipo de cuidado diferenciado com as parturientes, sendo as mesmas colocadas próximas a outros doentes ou a mulheres que haviam dado à luz e agonizavam de febre puerperal. Michelet (1995: 310) refere-se a estes locais como 'casas lúgubres', impregnadas de miasmas que tantas vidas maternas colhiam:

Sempre entrei aterrorizado nesses velhos e sombrios conventos que servem de hospitais hoje. Por mais que a limpeza das camas, dos soalhos, dos tetos seja admirável, é das paredes que tenho medo. Nelas sinto a alma dos mortos, a passagem de tantas gerações desaparecidas.

Para Michelet, a reforma hospitalar na França devia começar atendendo primeiramente as mulheres que estavam mais suscetíveis aos contágios, sendo arrebatadas em massa pelas febres no momento de dar à 
luz. Como grande admirador dos médicos, Michelet antevia novos tempos, melhores e mais humanos para o atendimento às mulheres, com a descentralização hospitalar, que começara a ocorrer por volta da década de 1850, e a assistência médica a domićlio defendida por alguns médicos.

Mesmo com a criação de espaços exclusivos para o atendimento às puérperas, a mortalidade mantinha-se elevada, permanecendo a mesma imagem negativa das maternidades como 'casas de morte', ainda por algumas décadas, até que métodos simples, como a higiene das mãos dos médicos com água, escova e sabão e o isolamento das mulheres, fossem adotados nas maternidades.

Quando a ameaça da febre puerperal começou a ser afastada no fim do século XIX, iniciou-se uma verdadeira campanha em favor do atendimento médico às classes pobres, especialmente às mães e aos recémnascidos, tendo em vista as altas taxas de mortalidade infantil denunciadas pelos médicos. Crescia a conviç̧ão de que as crianças podiam ser salvas se o atendimento médico adequado começasse antes do nascimento, com a puericultura intra-uterina.

As reformas nas maternidades européias, o atendimento médico domiciliar e a construção de hospitais pediátricos fazem parte, por um lado, de um conjunto de medidas oficiais para combater a mortalidade materna e infantil e, por outro, marcam o início de uma nova etapa na intervenção médica sobre os processo da gravidez e do parto, em que a maternidade passa a ser o espaço mais adequado e seguro para a mulher dar à luz e a criança receber os primeiros cuidados.

Enquanto na Europa a discussão era direcionada para a construção desses estabelecimentos hospitalares; no Brasil, a questão foi abordada esporadicamente por poucos interessados no assunto. Somente no início do século XX a discussão sobre a proteção à maternidade e a infância passou a envolver maior número de médicos e a adotar um tom mais político-ideológico. A Revista de Ginecologia e Obstetrícia do Rio de Janeiro publicou parte desta discussão em suas páginas iniciais, divulgando as idéias de alguns dos mais influentes médicos obstetras, ginecologistas e pediatras da época a respeito da assistência médica às mães e às crianças recém-nascidas.

Logo nos primeiros números da revista foram reproduzidas as comunicações do Dr. Jaime Silvado e do Dr. Alberto de Oliveira Motta, apresentadas em congressos médicos a respeito da puericultura no Brasil. 
Em ambos critica-se com veemência o descaso das autoridades com a infância e a maternidade dos mais pobres, verificado pela ausência de uma política de assistência pública e pela carência de hospitais e ambulatórios bem equipados. ${ }^{16}$

A discussão a respeito da criação das maternidades nos dois artigos é decorrente de um problema considerado mais urgente não só para o indivíduo, mas para o país: a atenção à infância. Desde meados do século XIX, a educação e a saúde da criança eram objeto de preocupação dos médicos higienistas que condenavam as práticas dos pais, das amas e dos preceptores, apontando-as como responsáveis pelas altas taxas de mortalidade infantil, pela debilidade dos corpos e a lassidão moral. ${ }^{17}$ Várias teses médicas e memórias sobre a higiene da infância e estudos a respeito das causas da mortalidade foram produzidas na segunda metade do século, todas atribuindo responsabilidades aos pais e pregando uma nova orientação na criação dos filhos, pautada, evidentemente, pelos princípios higiênicos, e conduzida pelos médicos mediante o aconselhamento familiar, a formulação de regulamentos e prescrições de condutas.

$\mathrm{O}$ discurso médico sobre a infância, produzido no início do século XX, tinha, portanto, uma razoável fundamentação em princípios e informaçoes que foi ampliada com a discussão em torno do valor da infância não só para as famílias, mas para a pátria. Aprimora-se o conceito de criação de crianças, ou da puericultura, entendido como o conjunto de medidas adotadas para aumentar a natalidade, como a higiene no casamento, a prevenção de doenças infantis e um grande número de regras higiênicas no cuidado com a criança, referentes à habitação, à alimentação, ao vestuário, aos cuidados corporais, aos exercícios físicos e à educação.

Como a puericultura devia ser iniciada antes do nascimento da criança, cabia ao ginecologista e ao obstetra desempenhar o papel de puericultores, prevendo e tratando doenças que podiam impedir o exercício da maternidade ou que viessem atingir a saúde do feto. Nos artigos de Silvado e Motta havia uma grande preocupação com o feto, com sua formação e bem-estar no corpo materno, algo que até então não era comum nos escritos médicos.

Como obstetra, o médico praticava a puericultura intra-uterina, acompanhando a evolução da gestação, medindo, auscultando, apalpando, enfim, colocando em prática o olhar e o tato investigador. Silvado e Motta insistem na individualidade do feto e na importância dos exames periódicos nas grávidas para prevenir doenças que viessem a colocar em risco a saúde 
da mãe, como a albuminuria gravídica, ou a saúde do feto, evitando abortos ou nascimentos prematuros em uma época em que pouco se podia fazer para mantê-los vivos.

Se até então as prescrições dos obstetras eram normas de pouco alcance, a não ser entre as mulheres que confiavam em seus médicos particulares, o que era uma parcela bem pequena da sociedade brasileira do século XIX, a partir do início do século XX os médicos perceberam que os seus conselhos quanto à saúde e ao bem-estar das mulheres e das crianças não surtiriam efeito se o seu público-alvo não fosse ampliado consideravelmente. Os médicos não podiam mais contornar as diferenças sociais, afinal, elas tornaram-se um empecilho às suas reformas em prol da construção de um povo saudável e preparado para conduzir o futuro da nação. Suas prédicas higienistas chocavam-se com a realidade das mulheres pobres que precisavam trabalhar para viver e não tinham meios para pagar um médico, procurando assim os serviços das parteiras ou comadres. A solução para o problema estava, segundo Silvado e Motta, na organização de uma Assistência Pública mantida pelo governo responsável pela criação de maternidades, ambulatórios, distribuição de enxovais e o pagamento de indenização para as trabalhadoras no período que se ausentassem do trabalho. Este discurso assistencialista começou a encontrar um número significativo de adeptos, especialmente entre os médicos mais famosos da época, principais defensores de uma obstetrícia social, voltada para a disseminação dos preceitos higiênicos e científicos entre a população mais pobre dos principais centros urbanos brasileiros.

Em uma época em que os direitos dos trabalhadores eram assunto de polícia, aventar a possibilidade de uma compensação às mulheres operárias para que elas pudessem se afastar do trabalho temporariamente era algo bastante ousado e que não se concretizou. Os médicos chegaram a referir-se à insensibilidade dos patrões, mas a crítica maior foi endereçada ao governo, cuja atuação na saúde pública era considerada irresponsável.

O Dr. Silvado atribuía à prefeitura da capital federal o dever de criar um serviço de atendimento médico domiciliar e uma maternidade modelo, pois as instalações das duas enfermarias de parto do Hospital da Caridade estavam, segundo sua avaliação, abaixo da crítica. A insistência dos médicos resultou na fundação da Maternidade das Laranjeiras em 1904, cujo número de leitos era ainda pequeno, e na organização de um serviço de assistência domiciliar prestado pelo Instituto de Proteção e Assistência à Infância, 
numa espécie de ambulatório que o Dr. Silvado denominou 'Dispensário Moncorvo', em homenagem a um dos iniciadores da pediatria no Brasil.

Todavia, este serviço atendia a um pequeno número de mulheres, tendo em vista suas limitações de pessoal. Cabia ao governo prover a população feminina de atendimento obstétrico e ginecológico, seguindo o modelo dos países europeus, que, na virada do século XIX, já contavam com uma rede hospitalar razoável e um conjunto de instituições de caridade públicas e privadas cujo objetivo era amparar e educar as mães pobres. ${ }^{18}$

Contudo, o governo brasileiro não reagia como os médicos desejavam, o que gerava páginas de censura pela ausência de visão dos governantes a respeito da necessidade de políticas de gerenciamento da saúde da população. A situação criticada pelos médicos no início do século XX resultava de um longo período de descaso das autoridades com a saúde pública de uma forma geral, e, em particular, com o atendimento prestado à população nos precários hospitais que existiam desde os tempos coloniais.

$O$ atendimento obstétrico no Brasil foi incipiente até o começo do século XX, apesar de algumas poucas tentativas para reverter a situação. Na mesma época em que Stéphane Tarnier fazia seus estudos sobre a febre puerperal na Maternidade Lariboisière em Paris, observando as pacientes ou fazendo autópsias, as pobres e desequipadas enfermarias dos hospitais de caridade da Bahia e do Rio de Janeiro acolhiam no mesmo espaço diferentes tipos de doentes, entre eles algumas poucas parturientes.

Pode-se ter alguma idéia das condições de saúde das mulheres que procuravam aqueles hospitais através dos livros de matrícula dos doentes, nos quais eram registrados o nome, a idade, a cor, o estado civil e a profissão, bem como o diagnóstico, e se a paciente havia deixado o hospital viva ou morta. De acordo com Johildo Athayde (1975), os diagnósticos não eram muito confiáveis, pois mais descreviam os sintomas do que as doenças, além de abusarem de termos muito vagos.

Esse problema da documentação foi observado no registro das doentes da enfermaria de mulheres onde podem ser lidos vários diagnósticos como 'maluca', 'bêbada', 'desinteria', 'inválida', 'jatos', 'dor no joelho', entre outros do mesmo tipo. Das 31 mulheres que entraram na enfermaria do Hospital da Santa Casa de Misericórdia de Salvador no mês de outubro de 1852, nenhuma apresentou diagnóstico obstétrico e somente um diagnóstico ginecológico, o que demonstra como as enfermarias de mulheres não eram procuradas pelas parturientes servindo como último recurso para 
mulheres como Jesuina Rosa de Lima, 62 anos, parda, solteira, mendiga, diagnosticada como 'maluca'. ${ }^{19}$

Segundo Fernando Magalhães (1922b), as enfermarias de partos criadas no século XIX não alteraram muito as condições precárias do atendimento hospitalar de forma geral, sendo realizadas cirurgias em camas improvisadas e não havendo isolamento das parturientes. Esta situação parece ter perdurado até o começo do século XX, com a criação das maternidades.

$\mathrm{O}$ atendimento obstétrico e ginecológico era realizado no Brasil de acordo com a origem social e racial das mulheres. Aquelas que podiam pagar e estavam cercadas de atenções familiares eram atendidas geralmente em casa pelo médico de família ou por uma parteira de confiança. As mulheres pobres, mas que ainda tinham algum recurso, também recorriam às parteiras. Somente as mulheres que viviam na mais completa miséria e abandono procuravam as enfermarias dos hospitais.

Foi para atender às mulheres que podiam pagar e aos donos de escravas que se multiplicaram, no Rio de Janeiro, algumas clínicas privadas e pequenas maternidades administradas por médicos e parteiras que anunciavam seus serviços nos jornais. Segundo Fernando Magalhães, as primeiras casas de saúde que prestaram serviços obstétricos e ginecológicos foram criadas em 1850 - Casa de Saúde do Sacco do Alferes e da Gamboa -, mas até a época das maternidades ainda havia anúncios de clínicas privadas conforme se pode ver nos jornais e almanaques e também na Revista de Ginecologia e Obstetrícia.

Até o final do século XIX não houve nenhuma iniciativa visando ao amparo à maternidade das mulheres pobres que continuavam desassistidas, especialmente se os partos fossem complicados, com exceção de um projeto de lei apresentado por José Bonifácio em 1822, regulamentando o trabalho das escravas grávidas e puérperas que nunca entrou em vigor (Magalhães, 1922b).

Em 1877, o Dr. José Rodrigues dos Santos enviou à Câmara Municipal do Rio de Janeiro uma solicitação bem argumentada para que se criasse uma maternidade custeada pelos cofres públicos. Rodrigues dos Santos havia retornado de suas viagens de estudos pela Europa onde observara o funcionamento das maternidades e o aumento de seu número, principalmente na França.

A exposição foi bem redigida, iniciando com considerações a respeito da importância da maternidade para a sociedade e dos cuidados que a mulher grávida merecia. Referindo-se aos 'países cultos da velha Europa', o autor 
salienta como os governantes custeavam hospitais-maternidade para as mulheres que não podiam pagar. Diz que tais edifícios específicos para atender parturientes não deviam ser vistos como um luxo, mas como uma necessidade rigorosa, "um auxílio indispensável para que [as mulheres] possam preencher uma função - a reprodução da espécie - rodeadas daqueles cuidados e abrigos indispensáveis que entre nós só é privilégio das mais abastadas". ${ }^{20}$

Ciente das condições em que davam à luz as mulheres muito pobres, Rodrigues dos Santos apela para a generosidade dos vereadores, lembrando que ele mesmo testemunhara seus sofrimentos, o que o levou a tomar a iniciativa e a solicitar que a Câmara criasse e custeasse uma maternidade municipal para atender também a mulheres que não pudessem pagar. Além da solicitação, há um esboço de um regulamento da maternidade, no qual o médico enumera sua finalidade e as condições de admissão.

Apesar das palavras de urgência do médico, a Câmara só se pronunciou em 1880, instituindo a Maternidade Municipal de Santa Isabel. Responsável pela elaboração do Regulamento Interno, Rodrigues dos Santos trata de sua finalidade no Artigo $2^{\mathrm{o}}$ :

Seu fim é especialmente dar proteção às mulheres pobres, que sem poderem recorrer às maternidades particulares nem quiserem recorrer a da Santa Casa de Misericórdia. Também poderá receber mulheres grávidas pensionistas quer na sala comum, quer nos quartos particulares. ${ }^{21}$

Como a maternidade não tinha uma sede própria, teve de funcionar na Casa de Saúde Nossa Senhora da Ajuda nos seus dois anos de existência. Pelos relatórios enviados à Câmara, pode-se perceber a insatisfação de Rodrigues dos Santos, nomeado diretor, com a situação precária do funcionamento da maternidade em uma enfermaria daquela casa de saúde, o que estava longe do ideal. Mesmo assim, o movimento no ano de 1881 foi significativo: 62 parturientes. ${ }^{22}$

O mapa do movimento de partos demonstra a orientação de um médico informado pelos princípios da obstetrícia científica. Ao invés de diagnósticos imprecisos e vagos, o que se vê é o registro minucioso e objetivo das parturientes. Cada uma foi apresentada pelo nome, idade, nacionalidade, cor, condição, estado civil e seu histórico obstétrico. As primeiras mulheres atendidas na Maternidade Santa Isabel eram, na sua maioria, pardas, solteiras e estavam concentradas na faixa dos 17 aos 28 anos, sendo mais de $60 \%$ delas escrava. ${ }^{23}$ 
Apesar da falta de interesse dos vereadores, Rodrigues dos Santos elaborou o segundo relatório com detalhes dos atendimentos prestados, comentando que a febre puerperal fizera poucas vítimas na maternidade devido aos cuidados com a desinfecção. Informa que o movimento continuava muito expressivo e só não era maior devido à reação das mulheres ao funcionamento do curso prático de obstetrícia para alguns alunos da Faculdade de Medicina.

Embora cumprisse sua função atendendo mulheres pobres e tivesse boa aceitação, a maternidade deixou de funcionar em 1882 por falta de recursos. O assunto só voltou a público quando o catedrático de obstetrícia, Dr. Érico Coelho, passou a defender a necessidade de se construir uma maternidade municipal. Alguns meses antes da proclamação da República, o Ministério do Império aprovou um orçamento para a construção da Maternidade Santa Isabel, que ficaria sob a responsabilidade do diretor da Faculdade de Medicina do Rio de Janeiro. Essa nova maternidade, além de prestar atendimento às mulheres pobres, deveria proporcionar o ensino prático para os estudantes de medicina, afinal, este ainda deixava muito a desejar, nos moldes como era realizado na enfermaria do Hospital da Santa Casa. O governo destinou a verba de 30 mil réis para a construção do prédio na praia da Lapa, sendo designado o engenheiro Paulo Freitas para fazer a planta (Figura 9).

Essa planta é uma excelente representação das novas orientações da obstetrícia científica, tendo em vista que reúne, no mesmo espaço, a assistência social, a clínica e o ensino. Ao contrário das enfermarias dos hospitais de caridade onde conviviam doentes com diferentes tipos de enfermidades em um sistema de aglomeramento, a proposta apresentada pelos professores da Faculdade de Medicina do Rio de Janeiro (FMRJ) se fundamentava em um princípio de organização do espaço hospitalar totalmente diferente; além disso, era um hospital de mulheres - uma concepção já em execução na Inglaterra desde o final do século XVIII e na França desde a metade do século XIX. Os médicos brasileiros procuraram convencer as autoridades de que as especificidades do corpo feminino tanto no exercício normal de suas funções quanto na manifestação de suas patologias exigiam um espaço individualizado no qual as mulheres não corressem o risco de se verem expostas a outros elementos patogênicos.

Um aspecto importante nesta planta é a hierarquia dos espaços. Seu princípio organizador é, seguindo a análise de Foucault (1985), a intervenção 
sobre o doente - desde a entrada do prédio, onde se dá a triagem na portaria e na sala de consultas, bem como no primeiro registro de entrada de pacientes no centro burocrático do hospital que é a secretaria. Após o diagnóstico, a paciente é encaminhada para as respectivas enfermarias de ginecologia ou de obstetrícia, aguardando o momento do parto.

A hierarquia também está presente na distribuição dos espaços para a equipe médico-hospitalar. Há salas para os professores, assistentes, enfermeiras e parteiras. A previsão de salas de aula, de um centro cirúrgico localizado em um anfiteatro, biblioteca e laboratório revela a concepção de hospital-escola que seus organizadores pretendiam colocar em prática. Portanto, o hospital deixava de ser um espaço exclusivamente de cura para tornar-se um espaço múltiplo: de cura, formação e transmissão do saber médico (Foucault, 1985).

O plano, no entanto, não saiu do papel. O atendimento continuou sendo realizado da mesma forma nas enfermarias do Hospital da Santa Casa, para a indignação dos médicos, até que em 1904 é inaugurada a Maternidade das Laranjeiras, posteriormente incorporada ao patrimônio da Faculdade de Medicina.

Mesmo instalada em um prédio que foi reformado, a organização da maternidade seguiu os mesmos princípios esboçados na planta da malograda Maternidade Santa Isabel. Com dois pavimentos, abrigava um ambulatório para exames e curativos, uma biblioteca para o uso das enfermeiras e dos estudantes, enfermarias para o atendimento obstétrico, salas de cirurgia, de esterilização, bem como um gabinete anatomopatológico e um museu, além das instalações sanitárias, da cozinha, da lavanderia e um desinfectório. ${ }^{24}$

A Maternidade das Laranjeiras foi considerada na época como um exemplo de organização e de aplicação dos preceitos científicos da obstetrícia e da ginecologia. Como local de ensino também ganhou destaque, principalmente depois que o Dr. Fernando Magalhães assumiu a Cadeira de Clínica Obstétrica como professor substituto. Como resultado de sua atividade docente nas dependências da maternidade, seus alunos apresentaram 40 trabalhos no VIII Congresso Médico-Brasileiro realizado em São Paulo, reunidos num volume com 567 páginas, tratando de vários aspectos da clínica obstétrica e apresentando uma grande quantidade de observações e dados estatísticos sobre o movimento da Maternidade das Laranjeiras. ${ }^{25}$ 
Figura 9 - Maternidade de Santa Isabel

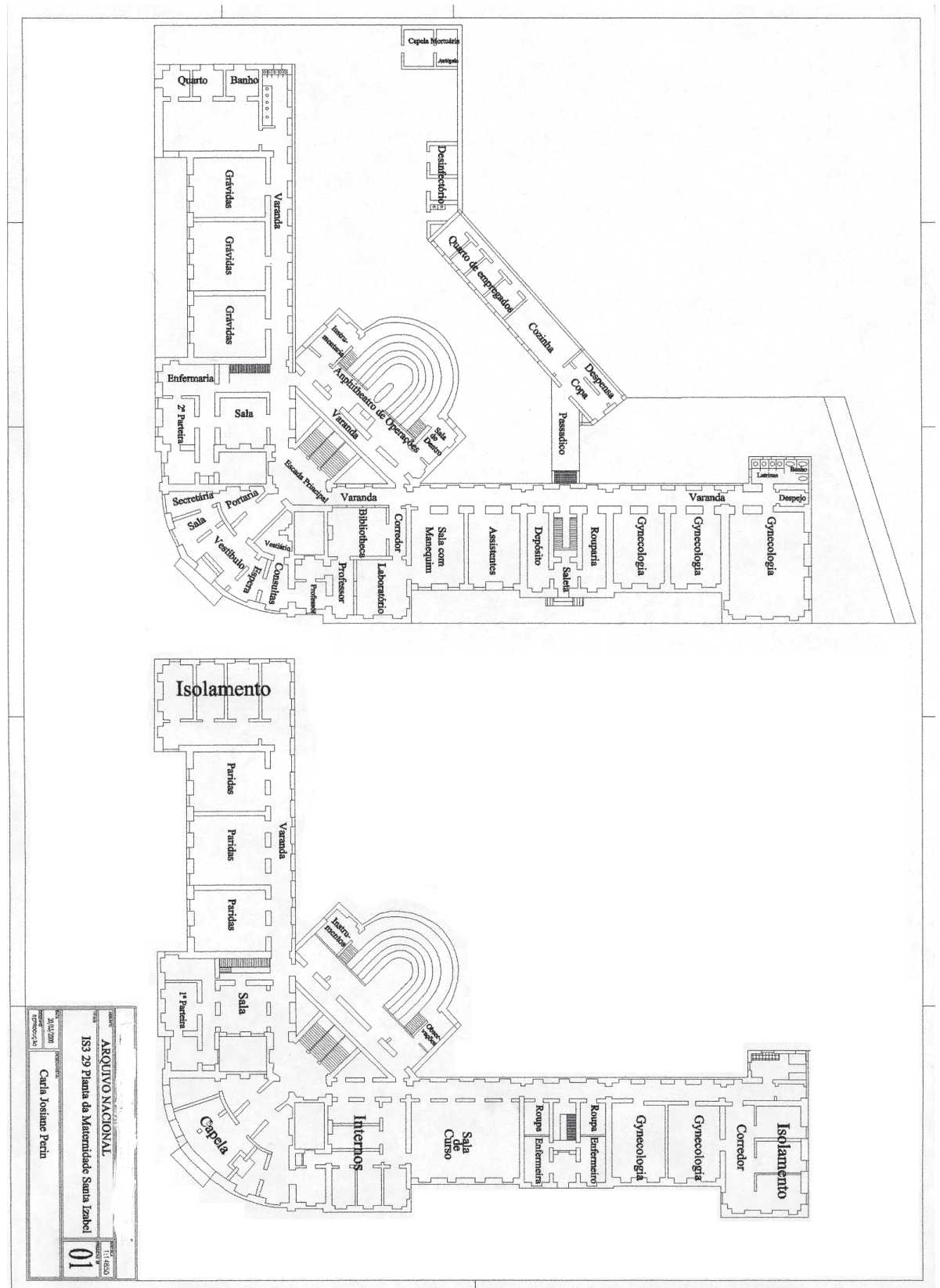

Representação das novas orientações da obstetrícia científica, o hospital maternidade devia reunir no mesmo espaço a clínica, o ensino e a assistência social.

Fonte: Arquivo Nacional. IS 29 - Obras do Ministério do Império. 
A articulação entre assistência, clínica e ensino foi razoavelmente realizada nesta maternidade, como se pode observar pelos registros divulgados na RGO, na qual freqüentemente eram publicados artigos resultantes da experiência obtida na clínica. Também divulgavam as estatísticas referentes aos procedimentos mais usuais, como a aplicação de fórceps, as versões e a operação cesariana que só começou a ser praticada com mais segurança a partir de 1915 devido ao processo desenvolvido por Fernando Magalhães que diminuiu a mortalidade por infecção.

No entanto, a maternidade tinha poucos leitos e ao longo de pouco mais de uma década os problemas começaram a surgir. Fernando Magalhães atribuiu as dificuldades ao descaso administrativo e ao afastamento dos princípios científicos que nortearam seus fundadores. Sua insatisfação era principalmente com o despreparo dos alunos e a falta de condições para atender as mulheres. O médico relata que vira bebês envoltos em jornal e que nada de efetivo se fazia para diminuir a mortalidade infantil. Em avaliação da assistência materna no Brasil, Magalhães (1922b: 233) não se furtou em fazer críticas: "Quanto à Maternidade das Laranjeiras, com que tristeza dela não falarão os que por ali tenham passado. Em matéria de assistência obstétrica, na capital da República, os cem anos de independência foram improdutivos".

Insatisfeito com as condições das Laranjeiras, Magalhães passou a defender vigorosamente a necessidade de se construir mais maternidades no Rio de Janeiro, pequenas, bem equipadas e que de fato cumprissem as três finalidades de assistência social, clínica e ensino. Além das maternidades, Magalhães lamentava a ausência de uma legislação que regulamentasse o trabalho da mulher grávida. Em conferência pronunciada na Associação Brasileira dos Estudantes em 1913, ele lançou sua campanha em favor da assistência materna, alertando os estudantes para as péssimas condições nas quais as mulheres pobres viviam a gravidez e o parto:

Nada de organizado existe entre nós capaz de proporcionar à mulher necessitada uma pouco de proteção. A proteção à mulher grávida ainda é, entre nós, uma aspiração: urge executá-la com um vasto programa de defesa da maternidade. Cumpre legislar sobre o trabalho, impondo o repouso antes e após o parto. (...) Imprescindível e inadiável é a criação do serviço de assistência à mulher-mãe, desde já representada pela construção de maternidades em pontos diversos do Rio de Janeiro. (Magalhães apud Magalhães, 1944: 19) 
Magalhães e outros médicos que também trataram deste assunto não se limitavam a exigir das autoridades a construção de maternidades, afinal a estrutura física de um hospital não garantia um bom atendimento, conforme vimos. Na verdade, aqueles médicos estavam começando a esboçar uma política de saúde materno-infantil que abrangesse qualidade de serviços médicos, assistência social, amparo da lei às mulheres grávidas e puérperas, instrução às mães sobre como bem cuidar dos seus filhos, colocando em prática a puericultura extra-uterina e, por fim, a formação de médicos, parteiras e enfermeiras.

A formulação dessa política iniciou-se em torno da construção das maternidades e devido à necessidade de uma legislação que protegesse a mulher trabalhadora, prevendo um período de repouso antes e após o parto. Estas questões vinham sendo debatidas na Europa especialmente por Pinard \& Wallich (1896), discípulos de Tarnier, que observaram as condições de trabalho das operárias grávidas e produziram um conjunto razoável de informações sobre os efeitos nocivos do trabalho exaustivo para as mulheres e os fetos. O impacto dessas pesquisas foi tal que, no Congresso de Obstetrícia, Ginecologia e Pediatria realizado em Nantes em 1901, decidiu-se por uma resolução na qual se defendia o direito das mulheres grávidas a receber cuidados especiais no final da gravidez e no primeiro mês após o parto, responsabilizando os governos para que assegurassem a regulamentação do trabalho das mulheres. ${ }^{26}$

No Brasil, esta discussão também agitava o meio médico, particularmente depois da publicação da tese do Dr. Eurico da Costa, Protę̧ão à Mulher Grávida Antes e Depois do Parto, na qual recomendava um período de 90 dias de repouso, e dos artigos de Oliveira Motta e Silvado sobre a puericultura. Contudo, o trabalho mais completo sobre o assunto foi a tese do Dr. Faustino de Castro, que mereceu publicação na íntegra na RGO.27 Seu trabalho versava sobre a necessidade de uma legislação que garantisse períodos de licença para as professoras por motivo de parto e puerpério e também sobre as faltas justificadas devido à menstruação.

Faustino Castro expõe em sua tese as idéias correntes no início do século XX sobre o trabalho feminino, antes condenado pelos médicos. Mesmo demonstrando reconhecer os direitos das mulheres a exercerem outras funções, o médico lamenta que a função reprodutiva não pudesse ser exercida pelas mulheres sem preocupações com a vida material, daí seu interesse pela regulamentação do trabalho e pela proteção à mulher grávida. 
De acordo com as opiniões médicas, Castro acreditava que as maternidades, os ambulatórios e as obras assistenciais e de caridade eram necessários para amenizar os problemas das trabalhadoras, mas, em sua opinião, se os homens recebessem melhores salários talvez nem houvesse necessidade de obras ou de leis: "Todo o homem que aufere o quanto baste para a sua manutenção e a dos seus tem o primordial dever, humano orgulho de entregar a esposa exclusivamente aos labores maternos, aos cuidados da sua prole".

Embora não pudessem reformar a sociedade do trabalho, tendo de procurar soluções para amenizar os efeitos da modernização, os médicos continuavam presos aos antigos modelos dos papéis de gênero, em que homens e mulheres tinham funções muito definidas e complementares. Se as mulheres pobres não se ajustavam à representação da mulher-mãe e dona de casa, cabia aos reformadores sociais adequar às realidades vividas pelas mulheres, proporcionando as condições mínimas para que cumprissem a função materna. Dessa forma, todas as medidas propostas e efetivadas, como a construção das maternidades, as obras assistenciais e principalmente a discussão sobre a legislação, devem ser entendidas como expressão das relações de classe e de gênero e como contribuição para a construção do discurso médico sobre a assistência materno-infantil no Brasil.

O acirramento das relações de trabalho no país no começo do século XX acompanhado de um notável crescimento urbano e da problematização da 'questão da mulher' pelos médicos e intelectuais proporcionaram as condições necessárias para a divulgação do ideário reformista da assistência médica, resultando na construção de maternidades em várias cidades brasileiras a partir da primeira década do século XX, como Salvador, Recife, Belo Horizonte, Fortaleza e Curitiba.

No Rio de Janeiro, Dr. Fernando Magalhães pôs em prática suas idéias a respeito da assistência materno-infantil, fundando a Maternidade PróMatre, que logo passou a servir de modelo para outras instituições similares. Graças ao seu empenho junto com Carlos Chagas durante a epidemia da gripe espanhola que assolou o Rio de Janeiro em 1918 e à amizade que tinha com o então presidente Wenceslau Braz, Fernando Magalhães conseguiu transformar um casarão onde passou a funcionar um hospital de emergência na maternidade que até os dias de hoje funciona na Rua Venezuela, nas proximidades da Praça Mauá. 
O objetivo de Magalhães não se esgotava na construção de mais uma maternidade, mas sim na de um espaço que fornecesse atendimento médico, assistência social e ensino; ele procurou a ajuda de mulheres da elite local, de famílias ricas e influentes, que pudessem auxiliá-lo na aquisição de recursos e na organização do trabalho filantrópico junto às mães e seu filhos.

Em 1918, Fernando Magalhães, Stella de Carvalho Guerra Durval e mais 14 senhoras da sociedade carioca criaram a Associação Pró-Matre, com finalidade assistencial visando a "proteger a mulher desamparada e a criança desvalida sem distinção de credos religiosos ou posição social". ${ }^{28}$

A função das senhoras da sociedade era angariar fundos para manter o hospital e a creche, que funcionava num anexo. Em 1919, o hospital foi inaugurado, inicialmente com 40 leitos distribuídos nas enfermarias de obstetrícia e ginecologia, consultórios, sala de partos e de cirurgias. Stella Durval comenta que pelos consultórios da Pró-Matre que prestavam atendimento gratuito passavam em média 162 mulheres por semana, logo nos primeiros meses em que começou a funcionar. ${ }^{29}$

Ao mesmo tempo em que criara uma maternidade-modelo na região portuária da cidade, Magalhães criou pequenos ambulatórios ligados à Pró-Matre em vários bairros do Rio de Janeiro. Dessa forma, ampliava-se o número de mulheres atendidas pela maternidade, algo que vinha ao encontro do ideal de Fernando Magalhães - expandir o atendimento obstétrico-ginecológico, chegando até as mulheres que viviam em bairros muito distantes.

Pode-se ter uma idéia do que era a organização científica da Pró-Matre através dos livros de observações clínicas. Estes livros não eram somente um registro de entrada e saída de pacientes, mas um histórico completo das condições clínicas e de todos os procedimentos realizados pelo médico e pelas enfermeiras. Cada paciente tinha seus dados pessoais e clínicos anotados em nove páginas. Na primeira, registravam-se os dados pessoais e da anamnese, como a idade da menarca, uma tabela como o traçado menstrual, o histórico de gestações, abortos, partos e puerpério. Na segunda página, havia o registro do exame físico geral; na terceira, o exame ginecológico e na quarta página, os dados obtidos com a pelvimetria externa e interna. A quinta página referia-se ao puerpério, comentando as condições de higiene da mulher, se houve infecção, as características do parto, o exame das mamas e um quadro relatando os dias em que a puérpera permaneceu no hospital. Caso ocorresse um quadro infeccioso, este era registrado na sexta página. A sétima 
e a oitava página eram reservadas para o registro dos dados sobre o recémnascido, com informações bastante detalhadas. A última página registrava o trabalho de parto, desde as contrações uterinas até os exames, a posição e a apresentação do feto e o tipo de parto.

Diferentemente das mulheres que foram atendidas na Maternidade Santa Isabel, na sua maioria solteiras e escravas, as mulheres que procuraram a Pró-Matre eram casadas e trabalhavam como costureiras, cozinheiras, lavadeiras, entre outras profissões voltadas para a prestação de serviços domésticos, ou seja, a clientela que Fernando Magalhães tinha em mente desde a época em que começou a defender a assistência materno-infantil.

A mesma preocupação com a assistência à mulher grávida e puérpera moveu o Dr. Climério de Oliveira a lançar uma campanha para a construção de uma maternidade em Salvador, inaugurada em 1910. Climério era professor de clínica obstétrica na Faculdade de Medicina da Bahia e foi um dos obstetras mais prestigiados em Salvador depois do Barão de Itapoan. Apesar dos esforços do Barão, as condições da enfermaria de partos do Hospital Santa Isabel não eram muito boas, o que afastava as mulheres. No ano de 1886, apenas 15 mulheres foram atendidas, e na época em que a maternidade foi criada, a enfermaria não chegava a realizar cem partos por ano. ${ }^{30}$

No que diz respeito às obras de assistência e filantropia, Salvador contava com algumas instituições desde o início do século, como o Instituto de Proteção e Assistência à Infância, fundado em 1903, o Dispensário Infantil e o Protetorado do Berço, todos visando à assistência infantil (Ferreira, 1906). Faltava, contudo, uma maternidade organizada segundo os princípios da obstetrícia científica. Climério de Oliveira juntou-se ao Comitê das Senhoras da Sociedade Baiana para arrecadar fundos para a obra.

Inaugurada em 1910, a maternidade recebeu, posteriormente, o nome de Climério de Oliveira, que foi seu diretor até 1914, ano em que se aposentou. O prédio que até hoje abriga a maternidade foi projetado para ter um pavimento dividido em quatro pavilhões, com enfermarias, consultórios, salas de parto e de cirurgia, instalações sanitárias, cozinha e lavanderia, ou seja, todas as instalações necessárias para a clínica e o ensino. Climério foi muito cuidadoso com os registros das pacientes feitos em livros especialmente destinados para o assento dos dados pessoais e clínicos, organizados da mesma maneira como foram os livros de registro da Pró-Matre, apresentando como diferença apenas a informação a respeito da cor das mulheres. A clientela da Maternidade Climério de Oliveira era 
composta por mulheres que também trabalhavam prestando serviços de doméstica, lavadeira, costureira, cozinheira, engomadeira, entre outros, mas eram, na maioria, solteiras e negras. ${ }^{31}$ Este perfil sociorracial demonstra que a clientela era composta pela população feminina negra e pobre que passou a encontrar na maternidade um socorro gratuito e mais eficiente.

$\mathrm{O}$ fato de a maioria das mulheres ser solteira indica como o discurso de proteção à maternidade abandonada começou a surtir efeito, atraindo cada vez mais um número maior de mulheres que viam na maternidade um abrigo para dar à luz e um refúgio do preconceito, como bem observou o médico curitibano Vitor Ferreira do Amaral, também fundador da Maternidade de Curitiba:

[A Maternidade] não podia deixar de esculpir em seu lema a obra humanitária da assistência médico social às mulheres grávidas, inclusive as mães solteiras, vítimas da fragilidade humana, mais dignas de comiseração do que do impiedoso ferrete com que as convenções sociais lhes costumam estigmatizar. (...) A Maternidade serve por vezes de refúgio ou abrigo, quando elas têm a desdita de se verem despedidas por seus patrões, que não as querem mais, ou repudiadas por seus pais ou responsáveis. ${ }^{32}$

A campanha dos médicos para a construção de maternidades no Brasil e a organização da assistência médica e social levantam algumas dúvidas quanto à periodização do processo de hospitalização do parto. Comumente aceita-se que esse processo tenha ocorrido a partir de 1960; no entanto, o que se observa pela documentação hospitalar é que as mulheres começaram a procurar as maternidades desde as primeiras décadas do século XX. Qual a explicação para a mudança do parto doméstico para o parto hospitalar? Possivelmente, não exista uma só explicação, mas um conjunto de circunstâncias que favoreceram a mudança.

Em primeiro lugar, não se podem desprezar as péssimas condições de muitos partos domésticos que eram atendidos por parteiras despreparadas para casos mais complicados. Há muitos testemunhos sobre estas situações, tanto de médicos como de parteiras diplomadas. A existência de um espaço no qual as mulheres fossem bem atendidas, recebidas nos consultórios pelos médicos, encaminhadas para salas de parto modernas e bem equipadas, sendo assistidas por parteiras bem informadas, certamente foi bem recebida pelas mulheres. Além disso, partos muito difíceis, que podiam colocar em risco a vida da mãe e da criança, passaram a ser resolvidos mais seguramente com a cesariana praticada nas maternidades. A mortalidade feminina foi 
significativamente reduzida com a anti-sepsia e o uso de novos medicamentos e técnicas que evitavam a infecção puerperal. Este era um dado que também não devia passar despercebido pelas mulheres.

Em contrapartida, não se pode esquecer do empenho dos médicos em divulgar junto aos seus pares, aos políticos e à população feminina o quadro preocupante da mortalidade infantil e a necessidade de se atuar mais na prevenção, começando pela atenção à saúde e ao bem-estar do feto e do recém-nascido. O discurso de proteção à mulher pobre e desamparada caiu em solo fértil, como se pode observar pelo perfil sociorracial das primeiras pacientes das maternidades brasileiras. Um outro aspecto importante a salientar é que os médicos brasileiros não foram tão rígidos e exigentes com as mulheres como ocorreu em hospitais estrangeiros, em que geralmente as diferenças culturais acabavam por gerar conflitos entre médicos e pacientes. Nos registros hospitalares, dificilmente se vê alguma referência à expulsão de pacientes por mau comportamento ou de abandono de tratamento, provavelmente porque os médicos brasileiros procuravam convencer as mulheres a ter seus filhos com assistência médico-hospitalar usando argumentos humanitários e filantrópicos.

Dessa forma, atualizados no conhecimento científico e formulando um discurso moralizador a respeito da maternidade e da proteção à mulhermãe, os médicos contribuíram para a aceitação do parto hospitalar. Iniciando o convencimento junto às mulheres pobres, os médicos só conseguiram ampliar a hospitalização e incutir o hábito das consultas antes do parto quando convenceram as mulheres de classe média e as mais ricas de que o hospital-maternidade era seguro e fornecia acomodações particulares e confortáveis para elas. Mas isso não ocorreu sem a formulação paralela de uma política oficial de saúde materno-infantil, desencadeada somente após a década de 30 do último século.

Na passagem para o século XX, já estava constituída a medicina da mulher no Brasil, apesar das dificuldades impostas pela precariedade do ensino e das instituições hospitalares que não eram adequadas para a clínica obstétrica e ginecológica. Especialistas em saúde da mulher e em sua especificidade sexual, os ginecologistas e obstetras brasileiros estavam mais preocupados com a formação dos médicos e com as condições de saúde das mulheres do que em produzir algum tipo de síntese a respeito da natureza feminina, como fizeram muitos de seus colegas estrangeiros. 
Como veremos no próximo capítulo, a chamada 'questão da mulher' instigou alguns espíritos menos avessos às polêmicas, resultando num conjunto pequeno, mas vigoroso, do pensamento médico e intelectual a respeito do assunto. Embora os discursos fossem direcionados a um pequeno número de leitores, são reveladores não só das idéias sobre a mulher, mas também da apropriação de teorias e doutrinas sobre as diferenças sexuais e da interpretação que deram a elas, formulando um discurso próprio a respeito da natureza feminina e do papel social da mulher.

\section{Notas}

1 'O Processo mnemônico para a aplicação do fórceps' era uma espécie de regra para memorização que o Dr. Climério de Oliveira ensinava para os alunos e está reproduzido na galeria dos retratos dos professores falecidos. Ele descreve cada passo para aplicar o fórceps, recomendando, como regra absoluta, a máxima prudência e delicadeza. Memorial de Medicina Brasileira da Universidade Federal da Bahia - Terreiro de Jesus - Galeria dos Retratos dos Professores Falecidos (1808-1842).

2 Boa parte dos livros de obstetrícia portugueses produzidos antes do século XIX são exemplos da sobreposição de conhecimentos eruditos do sistema hipocrático-galênico, dos primeiros tratados de partos do século XVI, da astrologia, de fórmulas mágicas e de receitas populares. A interação entre erudição, magia e cultura popular na medicina portuguesa permaneceu mesmo no século XIX com a publicação da Luz de Comadres ou Parteiras, de 1826, cujas prescrições para atender as parturientes envolviam beberagens com vinho, mel, raízes e plantas, infusões com pedras, o uso de preparados de origem animal, além das ventosas e friç̧ões com óleos. Sobre as matrizes filosóficas da medicina portuguesa, ver Bellini (1991); sobre os tratados de partos portugueses, ver Ribeiro (1990).

3 Ver Souza (1998: 37-56).

4 Ver Imfoh (1981), Shorter (1984) e Knibiehler (apud Duby \& Perrot, 1994).

5 Magalhães (1922b: 136) comenta que por essa época os médicos não auferiam lucros no atendimento aos partos. Um parteiro famoso da corte, como o Dr. Luiz da Cunha Feijó, Visconde de Santa Isabel, conseguia ganhar até 9 contos em um ano de melhor clientela. Segundo Magalhães, este era um dos motivos que levava os médicos a não exercer somente uma especialidade, praticando o que chamamos de clínica geral.

6 Ver Santos Filho (1991) e Magalhães (1922b).

7 Em seu artigo sobre o acervo da Biblioteca da Faculdade de Medicina do Rio de Janeiro (FMRJ), Lobo (1982) lista diversos volumes, todos em francês, de várias áreas, entre elas a obstetrícia e as doenças de crianças. Segundo seus dados, o acervo continha 3.423 volumes passando a ter 13.834 em 1883, entre os títulos produzidos na França, Inglaterra, Alemanha, Itália, Espanha e Estados Unidos. 
8 Os dados biográficos de médicos obstetras e ginecologistas foram obtidos nas pastas respectivas de cada médico arquivadas na Academia Nacional de Medicina, na Biblioteca Municipal do Rio de Janeiro e no Memorial da Faculdade de Medicina da Bahia - Galeria dos Retratos dos Professores Falecidos.

9 Afrânio Peixoto (1946: 44-49) refere-se especialmente aos hímens complacentes que foram a causa de muitos erros de julgamento por parte dos maridos e dos próprios médicos. Em matéria de hímens, o Dr. Peixoto foi um expert, tendo observado mais de 2.000 deles no Serviço Médico Legal, permitindo-lhe elaborar sua própria classificação de hímens.

10 Uma análise detalhada do Caso Abel Parente pode ser vista no quarto capítulo do livro de Rohden (2001).

11 O debate e as opiniões dos médicos foram divulgados pela RGO (ago.-dez., 1908). $\mathrm{O}$ artigo do Dr. Hugo Furquim Werneck, "Processo secreto de esterilização da mulher: documentos para sua história", foi publicado pela RGO (ago.-dez., 1908: 3).

12 Ver Werneck, "Processo secreto de esterilização da mulher: documentos para sua história", foi publicado pela RGO (ago.-dez., 1908: 3).

13 Oliveira Motta publicou a tese rejeitada em 1902 com o título "A esterilização da mulher: these recusada pela Faculdade de Medicina", o que demonstra sua disposição em não se curvar ao establishment médico, embora tenha se tornado um membro ativo do mesmo, vindo a ser vice-presidente da Sociedade de Obstetrícia e Ginecologia do Brasil na época em que foi fundada por Fernando Magalhães.

14 Ver Davin (1978).

15 Sobre o discurso positivista no Brasil a respeito da mulher, ver Trindade (1992).

16 Ver Jaime Silvado: Contribuição à puericultura no Rio de Janeiro. Revista de Gynecologia e Obstetrícia do Rio de Janeiro (ano I, n.2, set., 1907) e Alberto R. de Oliveira Motta. Subsídio para a puericultura nacional (ano I, n.5, dez., 1907).

17 Ver Capítulo 5 de Costa (1979).

18 Ver Davin (1978) e Thebaud (1986).

19 Livro 19o de matrícula dos doentes que entraram, saíram e faleceram no Hospital da Santa Casa de Misericórdia de Salvador (1847-1853).

20 Exposição dirigida à Câmara Municipal pelo Dr. José Rodrigues dos Santos sobre a criação da Maternidade, apresentando o esboço de um regulamento. Arquivo Geral da Cidade do Rio de Janeiro, 14 jan. 1877 - Códice 46-2-32.

21 Regulamento Interno para a Maternidade instituída pela Ilustríssima Câmara Municipal. Arquivo Nacional, 28 abr., 1880 - IS 9 - Manuscrito, Caixa 951. Império Saúde Pública.

2 Em termos comparativos, a enfermaria de partos do Hospital Santa Isabel de Salvador havia recebido 15 parturientes no ano de 1886. Relatório da Santa Casa de Misericórdia de Salvador, 1886, p. 29.

23 Mapa demonstrativo do movimento de partos na Maternidade Municipal de abril a dezembro de 1881. Arquivo Geral da Cidade do Rio de Janeiro - Códice 46-2-32.

24 A Maternidade do Rio de Janeiro. Renascença: Revista Mensal de Letras, Sciencias e Artes (ano I, n.1, mar., 1904). 
25 A Maternidade do Rio de Janeiro no VIII Congresso Médico-Brasileiro de 1918. Em 1894, foi fundada a Maternidade de São Paulo, cujo objetivo também era atender mulheres pobres, tendo como diretora a médica Dr. Marie Rennotte. Esta maternidade e outras que foram criadas no começo do século XX não fazem parte deste estudo porque optou-se pela organização da assistência materna nas cidades do Rio de Janeiro e de Salvador, onde teve início o ensino médico no Brasil. As informações sobre a Maternidade de São Paulo foram gentilmente cedidas por Maria Lucia Mott (1999).

26 Ver RGO (ano I, n.5, dez., 1907).

27 Castro, Faustino de. "Proteção legal à professora grávida". RGO (ano XIII, n.3, mar., 1919).

28 Estatutos Pró-Matre. Rio de Janeiro: Oficinas Gráficas do Jornal do Brasil, 1948.

29 Boletim da Pró-Matre (ano I, n. 2-3, maio, 1919). O movimento de pacientes na PróMatre era bastante grande. Segundo o boletim de janeiro de 1940, 21 anos após o início de suas atividades, haviam nascido 25.000 crianças na maternidade.

30 Relatórios da Santa Casa de Misericórdia de Salvador (1886-1921).

31 Registro Clínico da Maternidade Climério de Oliveira. Livro n. 2.

32 Maternidade Vitor do Amaral. Revista Médica do Paraná, 1932. 


\section{A Mulher no Discurso Médico e Intelectual Brasileíro}

Em seu livro sobre as afinidades eletivas entre a medicina e a literatura, Moacyr Scliar (1996) aborda um aspecto fundamental na formação dos médicos do século XIX: a cultura literária e humanista. Os médicos de então não eram somente versados na cultura científica, nem restritos à esfera da saúde e das doenças. Muitos deles dominavam vários idiomas, liam latim e grego, conheciam clássicos da literatura e da filosofia, interessavam-se por história e geografia, bem como cultivavam as artes. ${ }^{1}$

Essa educação ampla e variada contribuiu para que muitos destes médicos opinassem sobre diferentes assuntos e tivessem uma atuação mais diversificada, participando de sociedades culturais e da vida política, como se pode ver pelas biografias de um grande número de médicos do século XIX e da primeira metade do século XX. Como observou João Reis (1998), a cultura científica e humanista dos médicos contribuiu para seu reconhecimento e prestígio em uma época em que as elites eram pouco afeitas às ilustrações do espírito; estes médicos constituíam, junto aos bacharéis em direito, a elite pensante do país, ou conforme expressão do autor, a 'vanguarda civilizatória' do Brasil.

A crença na missão 'civilizadora' dos médicos levou-os a formular um projeto de reorganização da sociedade, visando a produzir indivíduos saudáveis no corpo e no espírito, capazes de efetuar transformações não apenas em suas vidas particulares, mas no destino do país. Para cumprir esta missão elaboraram um discurso reformista sobre as principais instituições que, segundo sua interpretação, eram responsáveis por graves erros e vícios na formação do povo brasileiro, a começar pela família, alcançando as escolas, hospitais, quartéis, prisões, mercados, cemitérios, 
enfim, milhares de espaços públicos e privados que deviam seguir as normas da reforma higienista. ${ }^{2}$

Desse projeto de intervenção médica na sociedade resultou um número expressivo de textos, a maioria de caráter normativo e escritos em um estilo acadêmico, objetivo e direto. Fazem parte desta coleção, os textos sobre a família, o casamento e a mulher, constituindo o saber sobre a sexualidade, a infância e o corpo feminino. Apesar do caráter ideológico, os textos que abordaram estes assuntos são mais descritivos do que analíticos, procurando construir sínteses de conhecimentos autorizados pela ciência ao invés de expor pontos de vista, conforme pudemos observar nas teses médicas a respeito da mulher. Isto não significa que os nossos médicos ilustrados se omitissem a respeito de questões polêmicas, como a chamada 'questão da mulher', que tantas penas fez correr no século XIX. Alguns se dedicaram a escrever sobre a mulher para o público leigo, deixando de lado a fria e restrita linguagem da ciência, recorrendo a um estilo mais livre, ensaístico ou até mesmo literário, através do qual podiam expressar suas opiniões e valores morais e, por que não dizer, suas ansiedades.

De acordo com Scliar (1996), quando o texto médico não é mais suficiente para conter a humana ansiedade do seu autor frente às vicissitudes da vida e à inevitabilidade da morte, resta ao médico recorrer a outra forma de expressão escrita: a ficção ou a poesia. Para alguns médicos que escreveram sobre a mulher, a forma e as convenções do texto científico nem sempre conseguiam aplacar a curiosidade ou conter suas idéias e opiniões pessoais, fazendo-os escrever ensaios, discursos e mesmo literatura. Embora não sejam numerosos os exemplos, são bastante emblemáticos do pensamento médico e intelectual a respeito da mulher e de seu papel na sociedade, um assunto que estimulou alguns dos mais destacados representantes da nossa elite intelectual entre o final do século XIX e inícios do XX.

Um desses autores foi Afrânio Peixoto. Como médico legista, uma de suas áreas de pesquisa foi a sexualidade, especialmente a feminina, realizando estudos sobre o defloramento e o estupro, além de sua experiência adquirida no Serviço Médico Legal, criado em 1907, do qual foi diretor e onde teve a oportunidade de observar o corpo de milhares de mulheres. ${ }^{3}$ Embora fosse um convicto defensor do método científico, teve de recorrer à forma literária para refletir mais livremente sobre seu objeto. Todos os seus livros são sobre a mulher, "o eixo de sua visão de mundo" 
(Peixoto apud Mota, Lopes \& Cóser, 1994: 160), como observou um comentarista de seus trabalhos. ${ }^{4}$

Liberado das amarras do texto científico, Afrânio Peixoto pôde expressar o que pensava a respeito das mulheres e das relações de gênero, revelando-se um misógino, sem a acidez de um Schopenhauer (1900) ou de um Weininger, mas reforçando representações já consolidadas na tradição literária e intelectual do final do século XIX, como a mulher fatal, por exemplo. Esta teve várias formas, sendo uma delas a esfinge, título do livro publicado por Peixoto em 1911, que foi bem recebido pela crítica e pelos leitores.

Neste romance lêem-se algumas das principais críticas que os médicos reformistas faziam à sociedade mundana, com sua artificialidade, bem como aos seus diversos tipos humanos. Além da vida social da elite, marcada por festas, chás, jantares e temporadas de verão em Petrópolis, Peixoto não poupou críticas ao regime republicano e aos seus políticos, questionando a cultura política brasileira marcada pelos interesses pessoais. Mas a crítica social e política não é o tema central do livro. O livro trata do dilema do homem que pode se perder pela paixão de uma mulher, dilema este antecipado pelo autor na epígrafe: "Na estrada de Tebas, Édipo encontrou a Esfinge, que lhe propôs um enigma tremendo. Se o não decifrasse, seria devorado como os outros. Decifrou-o, e foi o mais desgraçado dos homens" (Peixoto, 1947).

Para o autor, a esfinge moderna é uma mulher bela, educada, refinada, enigmática, afeita aos jogos da sedução, com o objetivo de caçar um marido, tal como a personagem Lúcia, paixão do escultor Paulo, homem jovem e sensível, educado, avesso ao mundo frívolo da sociedade carioca, onde Lúcia circulava com desenvoltura e sucesso. Seu amigo e conselheiro, o sábio médico Dr. Lisboa, alter ego de Peixoto, explica a Paulo que existem duas espécies de homens: aqueles destinados à reprodução - "são bonitos, férteis, pouco inteligentes, muito sentimentais; muitas maneiras e poucas idéias; as mulheres os adivinham imediatamente, gostam deles, com este faro instintivo de que são dotadas as abelhas (...) só procuram as flores que têm mel (...) destinam-se ao casamento" - e aqueles responsáveis pelas grandes transformações humanas - "feios ou bonitos, débeis, fortes, doentes (...) não importa, têm nervos, idéias, ilusões; trabalham e sonham. Mudam dia a dia a condição animal dos outros homens, fazem indústria, ciência, arte, moral, sempre perturbados pelos primeiros, mas sempre vitoriosos" (1947: 175). 
Paulo pertencia a esta segunda espécie de homens, e o Dr. Lisboa, vendo-o perdido de amor pela enigmática Lúcia, aconselhou-o:

Entenda bem. És um artista, completamente, em toda a profundeza da expressão. Virá a tua felicidade da perfeição a que atingires na tua arte (...). Porque és moço, um pouco de seiva primaveril te dá a ilusão do amor, que não bastará para a tua alegria. Encontraria aí decepções contínuas porque não poderias conciliar esses úteis interesses da espécie - casamento, mulher, filhos, criados, casa, doenças, posições, festas, prazeres - com as nobres necessidades de teu espírito, que aspira à manifestação de sua grandeza. Se tentares, serás vencido: um escultor de talento de menos, um desgraçado pai de família de mais. Porque serás desgraçado. (1947: 176)

Dr.Lisboa/Peixoto faz eco de uma tradição misógina bastante antiga e consolidada, na qual os homens afeitos ao cultivo das artes e do espírito deviam abster-se do contato com as mulheres, deixando a paixão e o casamento para aqueles que, pela falta de talento e de gênio, podiam desincumbir-se dos 'interesses da espécie'. Apesar de todos os reveses que Paulo sofreu por Lúcia, não deu ouvidos ao velho médico e casou-se com ela. Por fim, o médico conta a um amigo poeta que Paulo tornara-se um escultor de encomendas de bustos, túmulos e figuras decorativas, para sustentar a mulher, cumprindo o vaticínio: "um grande artista a menos, um pobre pai de família a mais" (1947: 378). Com essa frase, o autor encerra o livro e sela o destino de seu personagem, um homem talentoso e diferente de seus contemporâneos, mas ao mesmo tempo semelhante, por se deixar envolver pelas redes de artimanhas da mulher sedutora.

Nesse sentido, o livro de Peixoto é um alerta para os homens, um aviso sobre os perigos da paixão e representa as mulheres como criaturas frívolas, interesseiras, enigmáticas e maldosas, capazes de todos os artifícios para enredar homens incautos como o personagem Paulo, destinado a viver uma vida medíocre por causa da mulher.

Embora não se tenha desenvolvido uma literatura misógina no Brasil nos moldes da européia, romances como A Esfinge podem ser considerados representativos das idéias correntes no meio intelectual brasileiro a respeito da mulher e das relações entre homens e mulheres, grande parte delas idéias produzidas e divulgadas pelos médicos, através de textos científicos ou literários, como os de Afrânio Peixoto. Infelizmente são poucos os médicos que se lançaram à escrita literária, enquanto o contrário era mais comum, ou seja, escritores que recorriam aos textos científicos e médicos como modelos para o texto literário. ${ }^{5}$ No entanto, se tomados como 
exemplares de escrita masculina, tanto o texto literário quanto o científico são complementares, constituintes de uma mesma economia discursiva do gênero que tem na transformação do corpo feminino o objeto de análise, sua meta, seu alvo, seu projeto de poder. Ambos os discursos têm o mesmo fundamento, ou seja, partem da clivagem sujeito/objeto, e a mesma estratégia de produção do saber ao enquadrar o corpo feminino nos limites da narrativa literário-científica, tornando-o inteligível e supostamente 'adequado' à realidade.

Os textos científicos que vimos são discursos sobre a diferença sexual feminina, produzidos a partir da decodificação dos circuitos neuroreprodutivos, espécie de base física indelével responsável pela unificação das mulheres na categoria universal: Mulher. Esses textos não ficaram restritos ao mundo dos cientistas e dos médicos, mas serviram para confirmar inferioridades ou formular novas desigualdades, conforme analisamos no primeiro capítulo, sendo apropriados por outros intelectuais envolvidos com a questão da mulher. Nesse sentido, quando observamos estes outros discursos, percebemos como as mesmas ambigüidades detectadas no discurso científico são reproduzidas, fazendo com que os autores permaneçam divididos quanto à definição de sua companheira de espécie, bem como às suas atribuições e papéis sociais. Como um fantasma, a mulher parece atormentar a imaginação masculina, ora como mãe acolhedora, ora como fonte sedutora do mal, levando-a ao apaziguador terreno da racionalidade a fim de resolver esta ansiedade. Deste conjunto de textos, selecionamos alguns que abordassem as principais teorias e discutissem as idéias da época sobre a mulher, não havendo uma seleção por importância do autor, mas sim pelo tratamento do tema.

$\mathrm{Na}$ primeira parte deste capítulo discutiremos a ideologia da maternidade e a representação da mulher-mãe, presentes no discurso médico sobre a educação feminina. Este foi o argumento que levou alguns médicos a escrever livros de caráter pedagógico, procurando influenciar na formação das mulheres. Também foi a educação feminina o tema que levou um dos nossos intelectuais mais autênticos do século XIX, Tobias Barreto, a produzir um discurso extremamente perspicaz, não somente sobre o assunto, mas a respeito das teorias em voga que defendiam a tese da inferioridade da mulher. Não sendo médico, mas conhecendo o debate e os argumentos científicos, Barreto (1977) produziu um dos mais interessantes textos críticos a respeito daquelas teorias, sendo um defensor da educação superior 
para as mulheres numa época em que a maior parte das autoridades médicas e dos cientistas refutava esta possibilidade, aceitando a educação feminina apenas com fins pragmáticos, ou seja, para ser uma boa mãe e esposa.

$\mathrm{Na}$ segunda parte do capítulo, analisaremos o livro $A$ Mulher e a Sociogenia, do Dr. Tito Livio de Castro (1893), talvez o melhor exemplar do conhecimento científico sobre gênero produzido no Brasil no final do século XIX. Embora seu livro tenha sido escrito numa linguagem científica, era acessível para um público culto mais diversificado. Além de ser um livro que expõe as principais formulações teóricas evolucionistas sobre o sexo e a função da mulher, é também um libelo a favor da educação feminina, pois embora o autor acreditasse na inferioridade cerebral do sexo feminino, sua crença na evolução o fazia defender a educação com fins evolutivos para a espécie.

Tem-se, assim, um quadro sintético, mas bastante representativo das principais idéias e teorias sobre a mulher no meio médico e intelectual brasileiro no final do século XIX. Estas idéias e representações informam não somente sobre os autores e seu percurso intelectual, mas sobre a importância que a questão da mulher adquiriu naquele meio, bem como as propostas dos envolvidos no debate a respeito da melhor forma de amenizar os problemas sociais decorrentes das assimetrias entre os sexos. Avessos aos discursos mais misóginos de seus congêneres europeus e norte-americanos, os médicos e intelectuais brasileiros preferiram adaptar as teorias e as idéias a respeito da alteridade feminina às particularidades da realidade social $e$ cultural brasileira, procurando, ao mesmo tempo, definir a mulher e estabelecer sua função na sociedade, como a 'formadora de homens'.

Nesse sentido, discursos produzidos por médicos e intelectuais brasileiros tinham como objetivo, em primeiro lugar, situar-se no debate mais amplo sobre a questão da mulher em curso nos centros europeus e norte-americanos e, em segundo lugar, formular uma síntese sobre o tema, procurando adequar as duas principais correntes sobre a questão: aquela que mesmo reconhecendo a inferioridade física e mental das mulheres acreditava no poder transformador da evolução, defendendo a educação para elas como uma força evolutiva; e aquela, cujos principais expoentes são Schopenhauer e Weininger, que negava às mulheres qualquer forma de superação de suas 'deficiências', verdadeiras ameaças à integridade física e moral dos homens, ou esfinges, como as definiu Afrânio Peixoto. 


\section{A Formadora de Homens: a ideologia da maternidade e a educação feminina}

Os médicos brasileiros de meados do século XIX tiveram um destacado papel na formulação de projetos com a finalidade de intervir numa organização social que lhes parecia imprópria e inadequada aos seus padrões de civilização. Portadores do conhecimento científico, estavam convictos de seu papel junto às autoridades imperiais visando a transformar as principais instituições e os indivíduos em agentes de uma nova ordem social, fundada nos princípios da higiene e nos interesses econômicos e políticos do jovem Estado brasileiro.

A bibliografia que tratou das relações entre a medicina e o Estado no Brasil é unânime em apontar o caráter político dos projetos de intervenção na sociedade, muito embora não se possa falar de um projeto unitário, já que as propostas, as teorias e os modelos eram diferenciados, quando não antagônicos. De qualquer forma, sendo assessores, consultores ou mesmo críticos do Estado e das instituições, os médicos foram agentes privilegiados na produção de um conhecimento científico e social sobre a população brasileira e as instituições do século XIX, como expressou Madel Luz (1982: 16-17):

Os discursos médicos sobre a saúde revelam ser tanto modelos de conhecimento sobre a estrutura das doenças e suas causas, como propostas de intervenção saneadora e reorganizadora do espaço físico das cidades brasileiras - sobretudo nos centros urbanos portuários - e na vida das populações, no sentido de higienizá-las, discipliná-las e organizá-las para o tipo de relações sociais ascendentes na formação social brasileira.

Crentes no poder regenerador da Ciência e no inexorável avanço da civilização sobre a barbárie, os médicos reivindicaram a responsabilidade pela reorganização da sociedade, esquadrinhando todos seus espaços, inventariando os problemas e propondo soluções orientadas pelos princípios higienistas. Deste corpo de saberes interessam-nos os discursos produzidos a respeito da família, uma instituição-chave para os médicos, pois foi principalmente através dela que a 'questão da mulher' começou a ser problematizada no âmbito médico e intelectual brasileiro.

Entre os diversos problemas detectados, a mortalidade infantil e o 'descaso' com a criação dos filhos foram apontados como os mais urgentes a serem atacados pela orientação higienista, pois sendo a população uma das principais fontes de riqueza da nação, a família foi investida de uma nova função política: produzir bons e saudáveis cidadãos. ${ }^{6}$ 
De acordo com Isaac Joseph (1977), a família deixava de ser uma 'terra incógnita' para os médicos ao se tornar um espaço, por excelência, de uma "tecnologia da população, da conservação das crianças e do aperfeiçoamento da espécie" (1977: 56-57). Dessa forma, os médicos brasileiros produziram um conjunto significativo de teses, relatórios, artigos e livros sobre o tema da higiene familiar, empreendendo um outro esquadrinhamento dos indivíduos num território que até então era fechado às interferências externas. O objetivo dos médicos era transformar as famílias em unidades morais, células saudáveis da sociedade - atacando sua organização patriarcal, os hábitos familiares relativos à gestão dos corpos e da moral das crianças -, bem como fornecer aos pais novos modelos para preservar a vida de seus filhos. Para alcançar tais objetivos, tiveram de, pacientemente, introduzir seus valores e conhecimentos junto à clientela urbana e às classes elevadas, mais permeáveis às novidades e à autoridade do saber médico.

Para os médicos reformistas, a transformação da família passava, necessariamente, pela redefinição dos papéis de seus integrantes; desse modo, atribuíram novas responsabilidades aos pais, propondo normas para a educação das crianças e a organização do cotidiano familiar. Ao penetrar no espaço quase inexpugnável da família patriarcal, os médicos encontraram ali os principais obstáculos às suas reformas, mas também uma futura aliada: a mulher. Costa (1979) e Nunes (1982) abordaram este processo de objetivação da mulher por parte de discurso higienista, produzido ao longo do século XIX, bem como os procedimentos táticos a respeito dos mais diversos aspectos da organização familiar. Neste processo, segundo os autores, a figura da mulher foi reabilitada, sua condição elevada, sua importância enaltecida; enfim, de uma personagem secundária, passou a ser a principal e a ter um prestígio que até então era exclusivo aos homens, os chefes de família. Segundo Costa (1979: 73), a medicina inventou uma personagem cuja existência social era, até então, quase imperceptível:

Tradicionalmente presa ao serviço do marido, da casa e da propriedade familiar, a mulher ver-se-á, repentinamente, elevada à categoria de mediadora entre os filhos e o Estado. Em função destes encargos, suas características físicas, emocionais, sexuais e sociais vão ser redefinidas. A higiene passou a solicitar insistentemente à mulher que, de reprodutora dos bens do marido, passasse a criadora de riquezas nacionais. 
Foi, portanto, pela maternidade que se deu a individualização da mulher no discurso médico e intelectual. Tratava-se do resgate do papel da sua indiferenciação na instituição familiar, atribuir-lhe um novo significado. O enaltecimento da maternidade não era propriamente uma inovação dos médicos oitocentistas, afinal, desde os tempos coloniais, teólogos e médicos haviam elaborado uma imagem normalizada da mulher e do exercício da sexualidade, tentando impor às populações femininas o modelo da santamãe, conforme análise de Del Priore (1993) sobre os discursos masculinos da época a respeito do poder civilizador da maternidade.

Para os homens da igreja, a introjeção do papel materno e da simbologia cristã da mater dolorosa fazia parte de uma estratégia para controlar as mulheres e transformá-las em 'adestradas' transmissoras da moral tridentina, especialmente numa terra onde as relações eram fugidias e consensuais, desafiando escandalosamente as normas de bem viver elaboradas pela Igreja. Suas prédicas tinham como objetivo transformar cada mulher em mãe, devidamente instaladas no casamento, a fim de difundir a moral cristã e seus padrões de comportamento.

Os médicos oitocentistas tinham outra compreensão do papel da mulher na família. Mais do que responsáveis pela transmissão dos valores morais do catolicismo e da obediência à autoridade paterna, a mulher devia tomar para si a missão de criar os filhos, formar novos indivíduos, assumir integralmente sua função natural, empregando suas forças e todo seu tempo no exercício da maternidade. Embora não se possa subestimar a importância da religião na formulação dos discursos médicos sobre a maternidade, foram as 'leis naturais' que sustentaram sua visão sobre o papel da mulher-mãe.

Observando as teses que a partir da década de 1840 abordaram problemas relativos à infância e à educação das crianças, percebe-se a influência do discurso racionalista a respeito do papel da mulher na educação e na formação dos filhos. Leitores de Rousseau e dos médicos setecentistas que escreveram sobre a mulher, como Pierre Roussel - este citado até o final do século XIX -, Moreau de la Sarthe e Julien Virey, os médicos brasileiros elaboraram um discurso no qual a função materna foi devidamente articulada às demandas da Natureza e da sociedade. Dentro desta construção ideológica a mulher passou a ser vista como um elo importante entre os dois Estados, ou seja, cumprindo as leis da Natureza, sendo uma mãe cuidadosa, nutrindo e educando seu filho, a mulher desempenhava uma função social e moral ao produzir homens hígidos no corpo e no espírito, adequados para viver numa sociedade disciplinar. ${ }^{7}$ 
Redefinindo o papel da mulher-mãe, os médicos passaram a produzir uma verdadeira obra pedagógica sobre a maternidade. O quadro da vida familiar brasileira do início do século XIX parecia-lhes completamente inadequado aos princípios higienistas. As casas eram insalubres, os hábitos alimentares e de asseio corporal deploráveis, a educação física e intelectual abandonada, a educação moral não passava do aprendizado das preces e do catecismo, além do descuido dos pais ao permitirem liberdades entre seus filhos e os escravos. A situação da mulher era, igualmente, muito criticada. Deploravam sua vida reclusa e sedentária, restrita ao convívio com as mucamas.

Nesse sentido, os textos médicos compartilhavam da mesma visão negativa a respeito da população feminina e dos seus costumes e hábitos de vida presentes nos relatos dos viajantes estrangeiros que estiveram no Brasil no século XIX. Gendrin, comerciante francês que fez algumas viagens à América do Sul entre o final do século XVIII e início do XIX, comenta sobre a preguiça das mulheres brancas e sua crueldade com os escravos. A preguiça também chamou a atenção de Charles Expilly (1977), autor de um livro sobre as mulheres brasileiras, no qual deplora o desinteresse pela educação feminina, o excesso de coqueteria e de preocupação com a moda e a vida reclusa e sem motivação das mulheres:

Os bordados, os doces, a conversa com as negras, o cafuné, o manejo do chicote e, aos domingos, uma visita à igreja, eram todas as distrações que o despotismo paternal $e$ a política conjugal permitiam às moças e às inquietas esposas. $(1977: 269)^{8}$

Além das normas higiênicas sobre os mais diferentes aspectos da vida das mulheres que os médicos consideravam ser necessário modificar, voltaram-se para o problema da educação feminina. Esta questão mobilizou muitos autores na Europa, em especial na França revolucionária e bonapartista, onde foram publicados livros voltados para o público feminino, divulgando os preceitos ideológicos iluministas a respeito da naturalização dos papéis femininos na sociedade. A transformação da mulher e da família dependia de um programa pedagógico que abrangia o corpo, a moral e a educação intelectual. Somente uma mulher saudável e instruída podia exercer bem seu papel de mãe e também de esposa.

São os franceses os principais defensores da educação feminina voltada para a função materna, alguns deles autores de livros bem aceitos no Brasil, como Educação das Mães de Família (1834), de Aimé Martin; Conselhos às Mães (1837), de Théry; os livros do Monsenhor Dupanloup, Da Educação e 
Mulheres Sábias e Mulheres Estudiosas (1867), os de Michelet, e o livro O Papel da Mãe na Educação dos Filhos (1898), do Padre Didón, entre outros.

Livros como estes cumpriram um papel importante no duplo processo de exclusão das mulheres nos espaços públicos e no exercício da cidadania e de sua reclusão à esfera doméstica, ao produzirem física e moralmente os novos cidadãos. Estes e outros livros publicados na primeira metade do século XIX construíram a imagem da mulher-mãe e esposa instruída na religião, na higiene, nos afazeres domésticos e, principalmente, numa moral burguesa fundada nas hierarquias do mundo do trabalho e das relações de gênero. A educação feminina foi um eficaz mecanismo ideológico que tinha como objetivo principal dissipar as lembranças de um passado recente, no qual alguns homens e mulheres haviam vislumbrado uma sociedade onde a igualdade fosse um ideal aplicado também às relações de gênero. As publicações que defendiam a educação feminina não tinham em vista nenhum princípio igualitário, mas sim o de reforçar a segregação sexual ao apropriar-se dos saberes médico-científicos sobre o corpo feminino com a finalidade de dizer às mulheres que seu lugar era o lar, sob o controle amoroso de seu marido.

O primeiro livro publicado no Brasil sobre a educação feminina foi Cartas Sobre a Educação de Cora, em 1849, de autoria do médico baiano e professor da Faculdade de Medicina da Bahia, Dr. José Lino Coutinho. Seu livro é um exemplar das teorias rousseauístas sobre a educação da mulher, apresentando uma proposta pedagógica um tanto quanto avançada para a época em que foi escrito.

O 'escopo' do autor era elaborar um programa pedagógico para sua filha Cora, mas que, ao ser publicado, passou a ser um manual leigo de pedagogia feminina ao alcance do público leitor deste tipo de obra. Como leitor dos médicos iluministas franceses e dos tratados de higiene, Coutinho adaptou o conjunto de idéias a respeito da mulher ao seu programa para educar Cora, dividindo-o em três grandes etapas: a educação física, a moral e a intelectual. ${ }^{9}$

Coutinho acreditava que o processo educativo devia equilibrar esses três domínios, visando, mediante essa ação, formar uma "criatura sã e virtuosa" (apud Peixoto, 1936: 108). Muito distante da pedagogia religiosa, o autor pregava a liberdade de movimentos para a pequena Cora. Ela devia brincar à vontade, correr, saltar, o que era bastante ousado para a época se lembrarmos das freqüentes críticas dos viajantes sobre o comportamento afetado das crianças: 
(...) não se encontram no Brasil aquelas carnes sadias, aquelas faces gordas e rosadas, aquela frescura apetitosa das crianças européias, que são o enlevo das mães. Não se deparam no Brasil senão caras fatigadas, pálidas, sobre corpos frágeis e estiolados (...). Vive-se em presença de pequenos manequins ridiculamente enfatiotados, bonecos de mola que usam gravatas sérias, que pedem, com voz estudada, notícias de nossa saúde, que se mantêm admiravelmente em suas cadeiras, em vez de saltar aos nossos joelhos, de amarrotar os nossos chapéus e de procurar guloseimas nas nossas algibeiras. (Expilly, 1977: 253)

Gilberto Freyre (1992) também nos dá um quadro semelhante ao de Expilly ao falar sobre a educação das crianças, das formas de tratamento e da etiqueta familiar, lembrando que se os meninos eram transformados em miniaturas de seus rígidos pais, às meninas negava-se qualquer tipo de liberdade, sendo criadas desde pequenas para adotar um ar humilde e angelical, sempre sobre a vigilância dos pais.

É bem provável que Coutinho tivesse como modelo as crianças que desde o final do século XVIII foram representadas nas pinturas de interiores, nas cenas familiares e nos retratos - crianças robustas, coradas, livres nos seus movimentos e geralmente acompanhadas de suas mães. Para isso, era importante cuidar da alimentação de Cora, do asseio corporal, do vestuário que permitisse a liberdade para os jogos e as brincadeiras. Coutinho era contra os castigos físicos, acreditando que os castigos morais tinham maior eficácia na formação do caráter das crianças, o que demonstra, novamente, a sintonia de suas idéias com as novas orientações pedagógicas européias.

Outro aspecto bastante inovador na educação de Cora dizia respeito às experiências que nem sempre podiam ser agradáveis. Coutinho não imaginava para sua filha uma vida reclusa, nem rodeada de extremos cuidados que a impedisse de manter contato com o mundo:

Cora, veja e brinque com animais feios, ouça estrondos, acostume-se ao escuro da noite, à solidão das igrejas, com a vista dos mortos, para que se afaça à natureza, seja sem temores vãos e conheça o fim da vida (...). Nada de se lhe fazer todos os desejos e caprichos. (apud Peixoto, 1936: 108)

É interessante notar que as prescrições do autor visavam a acostumar Cora com coisas e situações que as meninas geralmente eram poupadas na época. Ao procurar fazê-la enfrentar situações desagradáveis, como o contato com a morte, a solidão, o escuro, os 'bichos feios', as trovoadas, Coutinho acreditava estar educando Cora sobre a diversidade da Natureza e incutindo-lhe uma formação moral baseada na verdade e na coragem. 
Um corpo são demandava uma inteligência cultivada. Cora devia aprender desenho, gramática, aritmética, leituras clássicas, francês, história natural - em especial as diferenças físicas e morais entre os sexos - história geral e do Brasil, geografia, astronomia, religião, direito, música, canto e piano. Uma educação tão cuidadosa como esta era um verdadeiro luxo se levarmos em conta os diversos relatos dos viajantes a respeito da escassa educação intelectual das mulheres brancas das elites, restritas à escrita e à leitura, noções de francês e de música. Coutinho era um homem ilustrado e possuía uma biblioteca diversificada, podendo elaborar um programa de estudos bastante avançado para a sua época.

O casal Jean Louis e Elizabeth Agassiz, em viagem pelo Brasil na década de 1860, comentou como era raro encontrar livros nas casas brasileiras e que as mulheres pouco liam, a não ser alguns romances franceses, folhetins ou tratados de moral que pouco ou nada contribuíam, segundo os autores, para sua educação intelectual. ${ }^{10}$

Coutinho, como médico que era, não descuidou da higiene na puberdade, com a chegada das 'regras' de Cora. Prescreve cuidados com o corpo e a moral, para evitar que a crise se prolongasse em patologias que os médicos bem conheciam e que ameaçavam a jovem adolescente. Essa era a época propícia, segundo o autor, para ensinar a Cora alguns ofícios próprios das mulheres, como os bordados, a tecelagem, engomar e passar roupas e cozinhar. Segundo o autor, mesmo com a presença das mucamas a mulher tinha de saber fazer os 'ofícios femininos', sem ter pejo destas atividades que contribuíam para sua educação moral. Coutinho antecipava uma máxima da educação das donas de casa presente até os dias de hoje: para saber mandar, é preciso saber fazer.

Nada sabemos dos resultados da educação de Cora, mas, como expressou Dr. Afrânio Peixoto (1936: 110), “Cora é uma educação real que precede a do seu país, no seu tempo, de muito tempo". Diríamos que Cora é a primeira mulher higiênica brasileira; afinal, Coutinho não tinha em vista outro futuro para sua filha que não fosse o casamento e a maternidade. Seu programa de educação física, moral e intelectual tinha como objetivo formar Cora para ser uma boa mãe, saudável, instruída nos mistérios da Natureza e nos conhecimentos que ilustravam o espírito, moldada no seu caráter pelas orientações morais que, no conjunto, a habilitariam para formar seus filhos da mesma forma que seu pai fizera com ela. Cabe ainda ressaltar como o Dr. Coutinho representa muito bem o modelo ideal de pai 
que dez anos depois Michelet louvou em seu livro sobre a mulher. Conforme analisamos anteriormente, a nova mulher devia ser uma criação do homem, pois somente ele estaria intelectualmente equipado para conhecer suas particularidades; dessa forma, a moldaria a seu gosto, transformando-a em uma agente civilizadora que deveria cumprir os ditames da Natureza.

Coutinho foi, além de pai, orientador de sua filha e, como tal, antecipava também o papel que os médicos higienistas tomaram para si ao escrever sobre a higiene familiar e o papel da mulher-mãe. Iniciava-se, com seu livro, uma literatura voltada para a educação feminina e o culto à maternidade produzida por médicos, mulheres cultas, como as editoras de jornais femininos, e intelectuais positivistas do final do século XIX. ${ }^{11}$

Embora o assunto fosse tema de várias teses médicas publicadas ao longo do século XIX, este tipo de publicação ficava restrita a poucos leitores, contribuindo, apenas, com a formação dos médicos, exclusivamente. Faltava, no Brasil, publicações voltadas para o público feminino que divulgassem as boas novas da higiene. Esporadicamente, surgia um ou outro artigo na imprensa, mas seu alcance era limitado, tendo em vista a ausência de uma coluna específica. Somente no final do século é que começaram a aparecer publicações mais voltadas para a divulgação do saber médico entre pessoas leigas, como o Dicionário Chernovitz (1890), por exemplo. As obras específicas sobre a educação feminina e a maternidade continuavam a ser os livros franceses, acessíveis aos médicos e às poucas mulheres capazes de lê-los.

Para suprir esta lacuna, o Dr. Carlos Antonio de Paula Costa, médico formado no Rio de Janeiro, publicou um pequeno jornal com periodicidade quinzenal, A Mãe de Família, entre 1880 e 1881. O objetivo do jornal era ensinar as mães como educar seus filhos seguindo os princípios higienistas, divulgando o aleitamento materno, os cuidados com a primeira infância, enfim, todo um conjunto de conhecimentos produzidos pelo saber médico a respeito da higiene familiar e do papel das mães como responsáveis pela saúde dos filhos. ${ }^{12}$

Na mesma época, um médico que vivia na província de São Paulo, na pequena cidade de Rio Claro, escreveu um livro para as mães de família. Trata-se do elogiado livro Arte de Formar Homens de Bem, de 1880, do Dr. Domingos Jaguaribe Filho, recomendado pela Academia Imperial de Medicina como um verdadeiro manual de higiene voltado para o uso das mulheres. 
Embora seja um livro de higiene infantil, boa parte é dedicada à educação da mulher, pois, para o autor, as duas questões eram indissociáveis: crianças saudáveis seriam homens fortes, e este processo dependia do papel educativo das mães. O que é mais característico deste livro é a visão pragmática do autor sobre o papel formador da mulher, bem como da maternidade. O título do livro não é genérico. A criança à qual ele se refere como objeto de todas as atenções maternais é a do sexo masculino. Nesse sentido, seu livro foi escrito para as mães por acreditar que elas seriam autoras de uma verdadeira reforma social que contribuiria para a grandeza da pátria: formar homens de bem. Para o autor e seus contemporâneos, falar de filhos ou crianças, significava falar de futuros homens, pois as atividades associadas à grandeza da pátria eram eminentemente públicas, políticas e, portanto, masculinas. Novamente, percebe-se aqui o eco de Michelet na idealização do bebê do sexo masculino. Ao comentar sobre as condições ideais para a mulher ter seu filho, Michelet (1995: 58) explica que a mulher-mãe vive o êxtase de ter gerado um deus:

Há espectadores ao redor do berço, no entanto a cena é solitária, tudo entre ela e ele, que são a mesma pessoa. Ela o olha fremente. Dela para ele, dele para ela, ocorre uma irradiação elétrica, um deslumbramento, que os confunde um com o outro. Mãe, filho, são a mesma coisa nessa vívida luz que restabelece sua primitiva, sua tão natural unidade.

Jaguaribe Filho foi um dos primeiros autores brasileiros a referir-se diretamente ao papel das mulheres como geradoras e formadoras de indivíduos do sexo masculino, uma idéia bastante comum nos discursos da época, especialmente quando se discutiam os exemplos de vida dos 'grandes homens' da história, como Santo Agostinho, Michelangelo, Goethe, Schiller, Napoleão Bonaparte, entre tantos outros, cujas mães eram sempre mencionadas devido ao papel que teriam desempenhado na sua formação.

Percebe-se, assim, a vitalidade e a continuidade de uma idéia bastante antiga - a de que a mãe é o espelho dos filhos - reforçada no século XIX pelos discursos científicos que prolongavam esta imagem especular da mulher por toda a sua vida reprodutiva, tendo em vista que os médicos e cientistas não viam outra função para o sexo feminino que não fosse a reprodução e a criação dos filhos. Idéias como estas estão expressas na apresentação do livro de Jaguaribe Filho (1880), feita pelo Dr. João Mendes de Almeida, advogado amigo do autor, para quem a mulher fazia uma família ser boa ou má, tudo dependendo de suas virtudes ou vícios. ${ }^{13}$ 
Nesse sentido, o livro de Jaguaribe é, na primeira parte, uma espécie de manual de pediatria. Nada escapa das teias da higiene infantil, começando mesmo pelo momento do parto, reprovando as práticas populares de cuidados com a mãe e o recém-nascido, dispensados pelas 'parteiras da roça' e as 'aparadeiras'. O autor e seus contemporâneos desenvolveram um discurso culpando as mães pela elevada mortalidade infantil, por desconhecerem os princípios da higiene relativos ao ar, à água e à nutrição, principalmente à amamentação. Aqueles homens ilustrados acreditavam que seu papel era orientar as mães, dissipando as trevas da ignorância e, assim, torná-las verdadeiras mães higiênicas.

A preocupação do autor era com a viabilidade dos recém-nascidos. Seu receio era de que, apesar das aparências, a criança fosse dada como morta pela parteira, sem que esta fizesse tentativas para reanimá-la, como massagens, borrifos de água ou até mesmo a desobstrução da garganta. Dessa forma, Jaguaribe tentava desqualificar os saberes das parteiras não diplomadas, pois alguns relatos demonstram como elas conheciam e praticavam alguns métodos impróprios para reanimar as crianças. ${ }^{14}$ Seu objetivo era, evidentemente, colocar em dúvida a prática dessas mulheres, com o objetivo de ensinar às mães como o recém-nascido devia ser cuidado segundo os princípios da Ciência, exortando-as a questionar os procedimentos das parteiras, como, por exemplo, o cuidado com os olhos do bebê, para prevenir oftalmias.

Livros como o de Jaguaribe Filho e tantos outros manuais escritos para as mães posteriormente procuravam transformar as práticas do parto e os cuidados com os recém-nascidos enraizados na cultura popular e nas experiências femininas, através de um duplo processo: a desqualificação daquelas práticas articulada à culpabilização das mães e a divulgação do saber médico como uma espécie de novo catecismo para formar boas mães capazes de criar bem seus filhos se seguissem tais conselhos. Os médicos começaram a se aproximar das mulheres a partir de discursos e de práticas voltadas para o cuidado e a criação dos filhos, um assunto que, certamente, as sensibilizou (como ainda sensibiliza); assim, foram se impondo lentamente no quarto das parturientes, passando a dar conselhos úteis sobre a alimentação, o vestuário e a saúde das crianças, afastando com prudência as parteiras, as parentes, as vizinhas, os maridos ansiosos, aceitando-os como auxiliares, mas jamais como seus substitutos.

Entre os conselhos médicos às mulheres destaca-se o tema da amamentação. Tema central na ideologia da maternidade, a amamentação 
foi um dos assuntos que mais motivou os médicos higienistas a escrever, pois a responsabilidade materna na nutrição da criança passara a ser vista como a maior demonstração do amor materno, sentimento este que, por sua vez, fora alçado à própria definição da mulher: a mulher que não amava seus filhos era uma aberração, uma criatura desnaturada.

Jaguaribe Filho (1880: 19) segue a cartilha higienista e condena veementemente as mulheres que por vaidade e falta de amor entregavam seus filhos às amas de leite. Primeiro as ameaça. Cita outros médicos e suas idéias mais fundadas na ideologia do que na fisiologia, como, por exemplo, a de que o leite não secretado pela amamentação recuava para "a massa do sangue e se lançava no cérebro ou no peito e em breve se manifestavam os mais terríveis efeitos seguidos de morte". Além desta incrível fisiologia, fala de doenças uterinas e cancros das mamas que atacavam preferencialmente as mulheres que insistiam em não amamentar. Abrandando um pouco seu discurso, recorre ao argumento da beleza, dizendo que as mulheres enganavam-se ao negar o seio ao filho temendo perder a beleza, pois, segundo sua interpretação, era a amamentação que o tornava mais belo. Citando a tese de um colega seu sobre o aleitamento, refere-se à famosa beleza das mulheres georgianas, que, por amamentarem seus filhos, conservavam a elegância e a beleza do porte até idade avançada.

Por fim, Jaguaribe retoma o argumento do amor materno, lembrando as doçuras da maternidade, experimentadas somente pelas mulheres que tinham junto ao seu peito um robusto filho nutrido com seu leite. Completando a argumentação sentimental, o autor faz uma comparação entre as qualidades nutricionais do leite da mulher com o leite de alguns animais. Como parte do processo de culpabilização das mulheres, os médicos tomavam o exemplo da natureza, lembrando como as fêmeas de outras espécies de mamíferos não se recusavam a amamentar suas crias.

Seus exemplos procuravam reforçar na mulher os sentimentos de responsabilidade e de amor, ao mesmo tempo que reforçavam as idéias científicas a respeito do lugar da humanidade na Natureza através da capacidade feminina de amamentar. Se o leite da mulher era tão rico em nutrientes quanto o leite das vacas, das cadelas, das éguas e das cabras, por que algumas mulheres se negavam a alimentar seus filhos, desperdiçando o alimento provido pela Natureza? Por que não seguiam o exemplo dos animais, já que a função nutricional da maternidade as tornava tão próximas? Com perguntas como estas, médicos como o Dr. Jaguaribe procuravam convencer 
suas leitoras a adequar-se ao papel da mãe higiênica, envolvida totalmente com a criação do seu filho, bem como incutir-lhes valores como a domesticidade, o amor sacrificial e o devotamento à maternidade, valores estes que encontraram solo fértil na religiosidade das mulheres, tendo em vista o culto à Nossa Senhora da Conceição e tantas outras representações da maternidade divina, tão presentes na cultura brasileira.

Definida a importância da amamentação, seu valor nutritivo, afetivo e moral, o autor passa a explicar como a mulher devia amamentar, prescrevendo os horários das mamadas, os cuidados com a higiene do seio e lembrando as mães que deviam pesar sempre a criança para certificar-se que a nutrição estava correta e adequada às suas necessidades.

Mas uma boa mãe apenas começava sua missão com a amamentação. Sua responsabilidade era muito maior, pois, além de dar a vida e nutrir o filho, devia exercer outra função tão importante quanto a primeira: a educação. Nesse sentido, Jaguaribe Filho é um seguidor de Spencer, criticando duramente o descaso dos pais com o desenvolvimento físico dos filhos. Ele recrimina especialmente as mães que entregavam os bebês às amas, não observando que algumas delas podiam segurar as crianças de maneira descuidada, gerando traumas, ou então prejudicavam o desenvolvimento físico e intelectual por carregarem as crianças o tempo todo, não proporcionando exercícios, distrações e brincadeiras.

Jaguaribe Filho exortava as mães a dedicar todo seu tempo aos filhos, acompanhando de perto seu desenvolvimento. Além da disponibilidade de tempo, os pais deviam pautar suas ações pelos conhecimentos da fisiologia, considerada a base segura para uma boa educação física. Aqui a referência é direta às recomendações de Spencer (1927), para quem os princípios fundamentais da educação física eram a alimentação equilibrada, o vestuário adequado à idade e ao clima e a necessidade de exercícios físicos, combatendo o excesso de estudos.

A respeito do equilíbrio entre exercícios físicos e estudos, Jaguaribe Filho mostra-se muito avesso aos costumes das elites brasileiras que ou exigiam que seus filhos "fossem doutores aos 20 anos" (1880: 53), ou se tornassem homens sem saber ler. O alvo principal de suas críticas é a ociosidade dos ricos que padeciam de doenças por não praticarem exercícios físicos, sendo desde pequenos carregados pelas amas e depois abandonados pelos pais à própria preguiça e aos maus hábitos alimentares. Para o autor, os pais deviam cuidar do desenvolvimento físico das crianças até os oito 
ou nove anos, estimulando jogos, corridas, brincadeiras ao ar livre, deixando para depois desta idade a educação intelectual. O mais importante era equilibrar as duas, pois a sobreposição de uma sobre a outra acarretaria em uma formação física ou intelectual desajustada.

Nos capítulos em que trata da educação física e intelectual o autor detém-se no que, para ele e muitos dos seus colegas, era um grave problema no Brasil: a educação das mulheres. No sistema que analisava não via uma só virtude; tudo era condenável na educação das meninas, a começar pela falta de exercícios físicos, a reclusão e a educação com base nas "prendas femininas", na leitura de romances e na excessiva preocupação com a moda. Sobre a educação física, o autor apontava a necessidade de profundas modificações, rompendo com a ociosidade das meninas e das moças, recomendando a natação, as corridas e a ginástica. Assim como Spencer, seu mentor sobre este assunto, Jaguaribe Filho não estava defendendo uma educação física visando a maior liberdade aos corpos femininos, mas sim corpos mais saudáveis e mais fortes para suportar as exigências do casamento e da maternidade. Para eles, o estilo de vida que criticavam não preparava a mulher para sua futura missão de reformadora social; assim, segundo Jaguaribe Filho, seus alertas e de outros médicos que se preocupavam com o assunto visavam a "desenvolver a educação das mulheres para que elas produzam homens de bem" (1880: 59).

As idéias divulgadas por Jaguaribe Filho foram formuladas pelos especialistas no corpo da mulher, entre eles, Raciborski, autor do mais importante tratado de emenologia do século XIX. Para este autor, todos os exercícios físicos eram convenientes para as moças na época da menarca, especialmente a ginástica rítmica. Segundo Raciborski (1868), a educação moral e intelectual seria melhor conduzida pelas mães, mas se não tivessem condições intelectuais para exercer esta função seria melhor mandar as filhas para um convento.

Todavia, os médicos não privilegiam a educação intelectual das mulheres. Percebe-se que o cuidado com a boa e saudável formação física e moral era mais importante do que a aquisição de conhecimentos, mais adequados para os cérebros maiores do sexo masculino, segundo as teorias craniológicas da época. Na sua tese de doutoramento, o Dr. Ramalho explica, com base em Raciborski e Spencer, que os homens não eram atraídos pela inteligência, mas pela beleza da mulher: 
Em todos os tempos, em todas as raças, em todas as hierarquias sociais, a beleza da mulher tem sido o maior atrativo do homem (...). O que vale uma inteligência culta em um organismo debilitado? Não se veja nestas linhas a menor sombra de indisposição contra a instrução das mulheres. É contra o modo pelo qual geralmente ela se faz que nos rebelamos. Desejamos as mulheres instruídas na medida de suas forças, aptas a serem verdadeiras mães, capazes de educar conscientemente e cônscias do papel altamente elevado que representam na sociedade. (Ramalho, 1906: 14-15)

Essa passagem da tese do Dr. Ramalho é representativa das idéias dos médicos formados pelas faculdades de medicina brasileiras. Expressa o que podemos chamar de reformismo conservador daqueles profissionais que não queriam parecer antiquados e nem inimigos das mulheres. As prescrições a respeito da higiene da puberdade e do tipo de educação que a mulher devia receber procuravam adequar sua especificidade sexual aos novos valores de uma sociedade moderna, organizada e disciplinada para a qual as mulheres deviam ter um papel ativo e político, ou seja, fundar com o homem a 'célula básica' da sociedade pelo casamento, produzir novos cidadãos e reproduzir, mediante a educação, os valores do trabalho, da ordem e da submissão aos mais fortes e poderosos, sabendo, desde a mais tenra idade, seu lugar na ordem social. Assim, para os médicos, a educação física já era, na sua essência, uma forma de educação moral para as mulheres.

Fundamentada cientificamente a necessidade da educação física e intelectual da mulher, Jaguaribe Filho passa, então, para o argumento mais importante na sua defesa das mulheres como educadoras: o argumento moral. É a partir de suas máximas a respeito do papel moral da mulhermãe que se percebe a dimensão que o autor pretende dar à maternidade e ao papel social da mulher. Seu discurso diverge dos misóginos que viam na mulher apenas a reprodutora do homem, quando não uma ameaça para o mundo masculino. Jaguaribe Filho procurava aliadas, não inimigas e, nesse sentido, seu discurso buscava elevar as mulheres, numa linha descendente de Michelet e dos autores de livros sobre a missão sagrada das mães, tão em voga ao longo do século XIX.

Para Jaguaribe Filho a educação moral seria uma atribuição natural das mães porque as mulheres eram moralmente superiores aos homens, outra idéia central na ideologia da maternidade. Formulada dentro de um pensamento circular, a superioridade moral era um atributo da capacidade feminina de dar à luz, amar e criar seu filho, funções estas que, por sua vez, se bem executadas, dignificavam a mulher e testemunhavam sua 
superioridade moral. O autor diz que a mulher é a obra-prima da Criação por ter sido escolhida para conceber, nutrir e criar o homem; por formarlhes o caráter e por dar origem a outras mães capazes de aprimorar esta missão, formando uma corrente materna que ligaria o presente, o passado e o futuro. Jaguaribe Filho e os médicos obstetras e ginecologistas sabiam que a maternidade não era um mar de rosas, por isso elevavam a figura materna e suas funções, atribuindo às mães um papel bem mais importante de que companheira do marido e mãe de seus filhos:

Do mesmo modo que se avalia a temperatura do corpo pelo termômetro, assim também pelas boas mães de família se podem avaliar as nações; elas não são só o termômetro social, mas ainda o espelho que reflete a grandeza ou a decadência de um país. (Jaguaribe, 1880: 67-68)

Da obscuridade e da repetição monótona das tarefas cotidianas exigidas da mulher-mãe, os médicos nada falavam, deixando implícito que os sacrifícios faziam parte de uma missão moral, e que esta missão tinha um significado político da maior importância, conforme expressou Jaguaribe Filho: “(...) é a mãe quem dá forma ao futuro cidadão e ele será todo ao seu molde; dela provem o caráter de seus filhos e destes provem a importância de sua Pátria" (1880: 69).

Definia-se, portanto, para esses autores, a maternidade como uma função política, exercida pela educação moral que a mãe dava ao filho. Era por esta razão que Jaguaribe Filho saía em defesa da educação feminina fundada em bases científicas, visando a transformar as mulheres em formadoras de homens saudáveis, bem adestrados para cumprir suas funções como soldados, políticos, homens de indústria, de leis e da Ciência, enfim, como o próprio autor os definiu, 'homens de bem'.

Contudo, nem todos os homens cultos da época eram permeáveis a estas admoestações de caráter moral sobre a necessidade da educação feminina. Alguns anos antes do Dr. Jaguaribe Filho publicar seu livro, o assunto foi tema de acirrada discussão num espaço freqüentado por 'homens de bem': a Assembléia Provincial de Pernambuco.

Os deputados tinham de decidir sobre a petição de uma moça que desejava estudar medicina, o que não era permitido nas duas faculdades brasileiras até a Reforma Leôncio de Carvalho, de 1879, que franqueou o ensino de medicina às mulheres. A petição foi analisada alguns meses antes da Reforma, sendo considerada improcedente por um dos deputados pareceristas, o médico Dr. Malaquias. Seus argumentos eram fundados na 
ciência biológica, especialmente na anatomia e na fisiologia das diferenças sexuais, cujos principais expoentes haviam estabelecido a inferioridade física e intelectual da mulher, baseados na comparação entre o peso do cérebro de homens e mulheres. O defensor da petição era o bacharel em direito, professor e futuro líder da Escola de Direito do Recife, o deputado Tobias Barreto.

O interesse de Tobias Barreto pelo assunto levou-o a apresentar, ainda no mesmo ano, um projeto de lei sobre a instrução superior para mulheres em Pernambuco. Sua idéia era criar uma escola pública de dois níveis, médio e superior, que fornecesse instrução literária e profissional, com o sugestivo nome de Partenogógio do Recife. O projeto chegou a ser debatido, mas um ano depois, quando Tobias Barreto já não era mais deputado, foi retirado de pauta por ser considerado 'despudorado e até imoral'. Comentando o fracasso de seu projeto, Tobias Barreto diz que seus objetivos visavam a tão-somente contribuir para a evolução intelectual da mulher, pois acreditava que a educação exercia um papel fundamental neste processo evolutivo, não tendo a intenção de defender os radicalismos emancipacionistas, como o exercício de funções públicas para as quais não acreditava que as mulheres estavam preparadas. ${ }^{15}$ Barreto mostra-se um defensor do ideário reformista a respeito da educação feminina, o que explica sua rejeição às teses feministas, pois, para ele, as mulheres ainda não podiam exercer funções para as quais não foram preparadas, tendo em vista as condições em que eram educadas.

Contudo, diferente dos médicos, Tobias Barreto não advogava a causa da educação feminina para transformar as mulheres exclusivamente em boas mães de família. Sua visão sobre o assunto era mais elaborada e avançada em relação a de alguns médicos. Para ele, a educação tinha uma função evolutiva, contribuindo para "a transformação de potências e o aumento de predicados" (1977: 316), fazendo com que a mulher superasse sua inferioridade em relação ao homem, alcançando uma posição mais digna, sendo capaz de exercer outras atividades além daquelas restritas ao casamento e à maternidade.

Conhecedor das teorias evolucionistas, Barreto não era, entretanto, um determinista, sendo crítico das idéias de Spencer e das adaptações a-críticas e mecânicas da teoria da seleção natural para os fenômenos sociais. Assim, define a evolução como desenvolvimento, uma idéia formada pelos conceitos de transformação e melhoramento, seguindo uma tradição que remonta a Geoffroy Saint-Hilaire passando por Lamarck e Haeckel. ${ }^{16}$ 
Crítico do determinismo biológico por ver nesta doutrina a negação do livre arbítrio, Tobias Barreto confrontou-se com as idéias mais caras aos médicos de sua época, especialmente aqueles que atuavam na sua área, os criminologistas e legistas. Sua "Crítica a Lombroso" (apud Lima, 1942) é uma boa amostra de seu pensamento.

Barreto não nega aos médicos a competência para definir o perfil psicológico e as características físicas dos criminosos, mas, para ele, os médicos deviam somente atestar e não julgar, afinal sua função era fornecer elementos científicos para quem, por direito, tinha de exercer esta função: o magistrado. Sua leitura do Homem Criminoso, de 1876, é uma crítica não apenas às idéias de Lombroso sobre o crime e os criminosos, mas também ao que ironicamente chamou de "hiperbolismo científico" (Barreto apud Lima, 1942: 188) dos médicos. Refere-se, em especial, ao excesso de dados craniométricos, dinamométricos, oftalmoscópicos, que qualificou como "epítetos sesquipedais" (Barreto apud Lima, 1942: 181). Este seria um dos grandes problemas do livro de Lombroso e, por extensão da crítica, dos discursos científicos:

Assim como existe, perante a lógica, um argumento vicioso que consiste em provar demais, também existe perante a ciência, alguma coisa de análogo e igualmente condenável: é esse processo que se delicia em observar demais, em acumular observações aparentemente profícuas, mas no fundo estéreis, incapazes de generalização, irredutíveis a uma lei. (Barreto apud Lima, 1942: 184)

Essas opiniões atacavam os pilares do conhecimento científico moderno e, igualmente, da medicina clínica, fundados nas observações minuciosas, nas mensurações e comparações entre os dados, criando novos conhecimentos a respeito das diferenças humanas. Barreto questionava exatamente o valor de tanta informação, colocando em suspeição as inferências produzidas pelo conhecimento médico-científico, como o fez mais detalhadamente no debate que travou com o Dr. Malaquias a respeito da mulher. Nesse sentido, Barreto é um crítico bastante perspicaz do significado de tanta ênfase na investigação das diferenças sexuais, percebendo o caráter ideológico da ciência sexual e também racial que partia do pressuposto das desigualdades utilizando-se dos dados quantitativos para reafirmá-lo como verdade.

Para entender melhor a discussão, é importante conhecer as idéias de Barreto sobre o assunto. Tanto no debate como em outro texto publicado 
em 1881, mostra-se um liberal, defendendo os direitos das mulheres à educação superior, ao exercício de uma profissão e a uma condição mais igualitária dentro da família e nas relações conjugais. Quanto aos direitos políticos, era mais conservador: "Sou relativista: atendo muito às condições de tempo e de lugar. Não havemos mister, ao menos no nosso estado atual, de fazer deputadas ou presidentas de província". ${ }^{17}$

O aspecto mais inovador do seu pensamento é, entretanto, a crítica àqueles que escreviam sobre a mulher. Segundo sua interpretação, a questão da mulher teria passado por três fases históricas: a fase poética e retórica, representada pela figura da deusa; a fase da execração, com o predomínio da imagem diabólica da mulher, e a fase do realismo científico, em que predominavam os médicos e cientistas que acreditavam possuir a verdade sobre ela. Desconfiado de um saber totalizante, Barreto questionou a extensão do conhecimento científico: "No domínio ginecológico ocorre algo semelhante ao domínio astronômico: por mais longe que vá o espírito observador, nunca poderá afirmar ter conhecido tudo que é cognoscível e capaz de entrar no campo objetivo dos seus instrumentos de observação." 18

Novamente Barreto questiona a estrutura do conhecimento médicocientífico, fundada na primazia do olhar. Se conhecer a mulher significava reduzi-la aos detalhes de sua anatomia e fisiologia, Barreto introduzia a dúvida ao apontar os limites deste conhecimento - que não era inválido, pois, sendo um materialista, o autor não propunha outra forma de conhecimento que não fosse baseado no exercício da razão -, mas tampouco era exclusivo e definitivo. Para ele, naquele momento o que importava era saber se a mulher instruída podia assumir outros papéis sociais tão importantes quanto aqueles desempenhados na esfera do lar, ou seja, Barreto estava forçando as cadeias do corpo nas quais o saber ginecológico, em especial, havia encerrado as mulheres.

Para Barreto a resposta era afirmativa, mas para o Dr. Malaquias, representante da Ciência no debate, a mulher não tinha capacidade intelectual para empreender estudos mais aprofundados, como a ciência e a medicina, pois seu cérebro era menor que o do homem. Tobias Barreto passa, então, a desmontar o argumento de seu oponente, passo a passo, começando por dizer que a teoria na qual ele se baseava era decrépita e anacrônica e, como tal, devia ser enterrada na mesma cova do dogma religioso do pecado original. Um ataque fulminante, pois comparava a Ciência à religião, ao afirmar que suas idéias a respeito da incapacidade feminina não passavam de uma reatualização do velho dogma judaico-cristão da maldição de Eva. 
Sua crítica é direcionada com maior ênfase e recriminação ao pensamento dogmático, especialmente às teorias fisiológicas a respeito do cérebro feminino:

Dar-se-á que a fisiologia seja também uma cigana? Dar-se-á que ela se arrogue o dom de predizer e ser infalível em suas predições? A fisiologia, da qual diz um homem competente que deve ser muito autorizado pelo nobre deputado, o Sr. August Laugel, como todas as ciências na infância, está sobrecarregada de observações, ou falsas, ou incompletas. (Barreto, 1977: 330)

Justamente os dados que os médicos e cientistas brandiam como a prova da "lei fisiológica", Barreto reduzia a um amontoado de informações que não eram passíveis de generalização.

Recorre à história para mostrar como as mulheres podiam exercer a medicina tão bem quanto os homens. Cita médicas russas, inglesas e norteamericanas que foram alunas elogiadas pelos professores e se tornaram muito respeitadas, como Elizabeth Blackwell, Marie Zakrzewska, Elizabeth Garret, entre outras pioneiras que venceram os preconceitos da época. Estes exemplos serviram para o próximo passo na desmontagem dos argumentos de seu oponente: a relação entre o peso do cérebro e o desenvolvimento da inteligência.

O Dr. Malaquias defendia uma idéia que nos meios científicos da época era considerada um princípio inquestionável: quanto mais desenvolvido fosse um órgão, melhor seria sua função. Esta relação entre peso cerebral e inteligência foi freqüentemente utilizada para estabelecer comparações entre raças, classes sociais e gênero, não só pelos médicos e cientistas, sendo uma idéia apropriada por outros discursos, como o político e o literário.

Tobias Barreto via nesta relação uma atualização da frenologia, já desacreditada no final do século XIX, cujo princípio não se sustentava. Argutamente faz uma questão que desestrutura a lógica materialista dos fisiologistas e anatomistas, perguntando ao Dr. Malaquias como ele explicava a diferença entre o peso do cérebro de Byron (2.238g) e o de Dupuytren (1.436g). Se a sua lei fosse aplicada à comparação, como explicar que um gênio da cirurgia como Dupuytren tivesse um cérebro menos desenvolvido que o do poeta inglês?

Em seguida, Barreto fez a pergunta fatal, questionando o peso normal do cérebro humano, ao que Dr. Malaquias respondeu que havia uma média. Barreto, então, chega ao âmago da questão ao dizer que média não significa normal e que entre os seres humanos havia diferenças de medidas, ou seja, as diferenças dos corpos ruíam com o conceito de normalidade, sendo impossível 
estabelecer qualquer lei a partir destes dados. Citando Haeckel e sua teoria da seleção natural, o autor acrescenta que em uma mesma espécie nunca se encontra indivíduos totalmente iguais, portanto, no que dizia respeito à diferenciação cerebral entre os sexos, não havia nenhum sentido concluir que pequenas diferenças entre as medidas significassem capacidades intelectuais tão distintas e desiguais. O exemplo das médicas estrangeiras era uma prova inquestionável, dizia Barreto, pois se o cérebro de uma Blackwell ou de uma Suslowa fosse menos pesado do que qualquer médico, em que importaria esta diferença se elas eram competentes e bem desempenhavam sua profissão? Em nada, respondeu, pois o problema da incapacidade intelectual das mulheres não era uma condição natural, mas o resultado de um processo histórico que havia negado sistematicamente a elas o acesso à educação nas mesmas condições que os homens.

Barreto recupera aqui os mesmos argumentos de autores do século XVIII, como Mary Wollestonecraft, Condorcet e Helvetius, fundamentados na tese histórica da condição inferior das mulheres. Se fossem dadas a elas as mesmas condições de educação, ficaria provado que a Natureza não as fez inferiores, mas sim a sociedade. Barreto acreditava nesta tese e defendeu-a no embate que travou com o representante da ciência das diferenças sexuais.

Os deputados que assistiam ao debate testemunharam o confronto de dois sistemas de idéias e valores antagônicos. O Dr. Malaquias defendia o discurso científico como suas idéias deterministas, criadoras e legitimadoras de desigualdades sociais, raciais e de gênero. Tobias Barreto não se opunha à Ciência, pelo contrário, foi um convicto defensor do evolucionismo e de sua utilização na renovação dos estudos jurídicos, mas não podia concordar com o determinismo científico, pois este contrapunha-se à sua formação humanista e liberal ao negar o livre arbítrio. Além deste aspecto, Barreto opunha-se à construção ideológica do determinismo, que naturalizava as diferenças sociais, produtos da história construída pelos homens e não pela Natureza, como era a questão da incapacidade intelectual das mulheres. Sua compreensão da ideologia cientificista foi expressa na crítica direta ao Dr. Malaquias, dizendo que ele não estava nos braços da Ciência como acreditava: "Engana-se; está com o catolicismo, está com São Paulo, está com os santos padres, que tinham dúvidas sobre a alma racional da mulher, como hoje se duvida do seu cérebro" (1977: 340). Para Tobias Barreto, a discussão sobre a capacidade intelectual da mulher devia ser equacionada em termos sociais e não a 
partir de conjecturas ou pressuposições como faziam os cientistas e médicos que 'observavam demais', chegando a conclusões que em nada contribuíam para a evolução da mulher e da sociedade. Nesse sentido, pedia à Assembléia que aceitasse a petição, esperando que seus colegas começassem a abrir "as portas da ciência ao belo sexo de Pernambuco: todo homem tem sua mania; e é infeliz aquele que não a tem. A minha, senhores, é pensar que grande parte, senão a maior parte dos nossos males vem exatamente da falta de cultura intelectual do sexo feminino" (1977: 346).

Certamente, Tobias Barreto não era o único a pensar dessa forma. No mesmo ano em que fez a defesa da instrução superior para as mulheres, o governo imperial permitiu sua entrada nas faculdades de medicina, acompanhando uma tendência liberalizante que estava ocorrendo em vários países europeus e nos Estados Unidos. Diferente do que ocorreu naqueles países, as brasileiras não tiveram de estudar em escolas separadas. Oito anos após esta decisão governamental, formavase a primeira médica no Brasil, Dra. Rita Lobato Lopes, defendendo, em Salvador, sua tese de obstetrícia sobre a operação cesariana (1887). ${ }^{19}$

A biografia de Rita Lobato e de suas colegas que entraram no mesmo ano na Faculdade de Medicina do Rio de Janeiro, Ermelinda Lopes de Vasconcelos e Antonieta César Dias, mostra que as idéias misóginas que fundamentavam os discursos contrários à educação superior para as mulheres não tiveram defensores muito convictos ou pelo menos dispostos a começar uma reação contra as jovens que entravam nas faculdades para estudar medicina.

Alberto Silva (1954) comenta que Rita Lobato foi muito bem recebida quando se transferiu para a Faculdade de Medicina da Bahia, tanto pelos professores quanto pelos colegas que a chamavam de Iaiá, convidando-a para festas, bailes e passeios, fazendo muitas amizades durante os três anos em que morou em Salvador. As informações sobre a vida profissional das primeiras médicas mostram que todas exerceram a medicina por muitos anos, enquanto Ermelinda Vasconcelos chegou a freqüentar cursos de renomados obstetras e ginecologistas europeus, estabelecendo, ao retornar para o Brasil, uma clínica para senhoras e crianças em Niterói.

Apesar de a proximidade entre homens e mulheres começar a ocorrer cada vez mais em outros espaços fora do lar e das relações familiares, as explicações científicas sobre a inferioridade feminina, tão criticadas por Barreto, não arrefeceram e nem perderam seu lugar na constelação de idéias 
no meio intelectual brasileiro. Na literatura, o romance naturalista retratava as mulheres como reprodutoras ou histéricas, enquanto as teses médicas continuavam a representar a mulher como uma criatura situada no limiar da fisiologia e da patologia. ${ }^{20}$

Em meio a tantas vozes, um jovem estudante da Faculdade de Medicina do Rio de Janeiro, certamente colega de Ermelinda Vasconcelos e de Antonieta Dias, escreveu um livro no qual tratava da 'questão da mulher', abordando-a cientificamente. Mesmo sem conseguir publicá-lo em vida, Tito Livio de Castro deixou registrado, de forma impecável, todo um conjunto de idéias sobre as diferenças sexuais, produzindo uma das mais instigantes e completas reflexões a respeito da mulher e seu papel social sob a ótica da ciência sexual desenvolvida pelos anatomistas, fisiologistas e ginecologistas que formularam o saber sobre o corpo feminino entre o final do século XVIII e inícios do XIX, base teórica e conceitual deste autor ainda pouco conhecido.

Corria o ano de 1893. Entre as dificuldades para sobreviver, já idoso e sem dinheiro, e as constantes visitas à tipografia da Casa da Moeda, o Sr. Manoel da Costa Paes, um português que vivia no Rio de Janeiro desde 1845, esforçava-se para publicar o livro de seu filho recentemente falecido. Foi a forma que encontrou para amenizar sua dor, mas também para homenageá-lo, divulgando suas idéias e o conhecimento que em tão pouco tempo de vida produzira. Não foi fácil conseguir a publicação do livro, embora se reconhecesse o mérito do autor. Mesmo contando com a aprovação de Rui Barbosa, os originais permaneceram intocados na Imprensa Nacional, talvez pelo descaso de algum burocrata. Sem arrefecer, o pai do escritor conseguiu que a Casa da Moeda publicasse o livro e finalmente em 1893 o público conheceu as idéias de Tito Livio de Castro a respeito da questão da mulher. ${ }^{21}$

\section{Os $150 \mathrm{~cm}^{3}$ : o determinismo científico sobre as diferenças sexuais}

Nascido em 1864 de pais desconhecidos, Tito Livio de Castro foi deixado na porta da casa de Manoel da Costa Paes, que o acolheu e o criou como seu próprio filho. Deu-lhe condições para estudar, primeiro no Liceu Comercial, depois no Colégio Pedro II, onde fez o bacharelado em letras. Em 1884, entrou para a Faculdade de Medicina do Rio de Janeiro, obtendo o título de doutor em 1889. Não chegou a exercer sua profissão, pois aos 26 anos faleceu vitimado pela tuberculose, deixando um número considerável de textos manuscritos, sua tese de doutoramento e os originais do livro A Mulher e a Sociogenia (1893). 
Silvio Romero foi seu professor no Colégio Pedro II e, ao escrever o prefácio do livro, comenta que já naquela época havia percebido seu talento e admirado o caráter e a disposição para enfrentar as dificuldades, não só materiais, mas especialmente aquelas decorrentes do preconceito, pois Tito Livio de Castro era negro, inteligente e admirado por alguns professores, o que certamente não passava despercebido pelas 'almas mesquinhas', como definiu Romero os detratores e perseguidores de seu ex-aluno.

O pai adotivo de Castro não poupou esforços para apoiá-lo, no que se referia à proteção das perseguições e à sua formação intelectual. Romero conta que chegou a conhecer a biblioteca que Manoel Paes formou para o filho, composta por volumes de diferentes áreas do conhecimento, onde provavelmente Tito Livio passou boa parte de sua breve vida estudando. O interesse pelos livros e por questões da vida social, política e cultural brasileira levaram o jovem a escrever desde cedo. Já aos 18 anos começou a produzir artigos, ensaios e reflexões sobre diferentes assuntos, que após sua morte foram publicados no volume "Questões e problemas". Neste pode-se perceber a ampla formação cultural de Castro, para quem assuntos como a condição social dos libertos, o romance naturalista, a música, a filosofia e a política não eram estranhos.

Durante os anos de faculdade fez alguns poucos amigos e juntos formaram um grupo de estudos no qual ele exerceu a liderança. Segundo Silvio Romero, eles praticavam a vivissecção, estudavam química, física e anatomia, o que demonstra o interesse daqueles jovens estudantes de medicina pela investigação científica, algo que não era muito comum no meio acadêmico brasileiro, em que se consumiam as grandes sínteses e as doutrinas, não se desenvolvendo uma atividade científica de caráter experimental pelo menos até as primeiras décadas do século XX. ${ }^{22}$

O interesse de Castro pelas ciências biológicas - em especial pela fisiologia - e pelo evolucionismo darwinista pode ser melhor avaliado pelo livro $A$ Mulher e a Sociogenia, escrito em 1887. Nesta obra pode-se ver que os principais nomes da ciência do século XIX eram bem conhecidos pelo autor, como também as teorias biológicas que procuravam explicar as diferenças raciais e sexuais. Embora utilizasse a teoria da evolução pela seleção natural para explicá-las, bem como os estudos de craniologia e antropologia, a ciência que lhe fornecia os principais argumentos era a fisiologia. Toda a construção de sua análise materialista da evolução dos sexos e das raças se fundamenta na fisiologia experimental e seu método quantitativo. Neste aspecto, o livro é um exemplar ímpar da apropriação 
dos conhecimentos das ciências biológicas sobre as diferenças humanas e da aplicação do evolucionismo darwinista à análise social.

Na época em que Castro escreveu este livro, médicos e intelectuais brasileiros costumavam equacionar os problemas nacionais com a questão racial. O debate sobre a viabilidade do país como nação e o problema da identidade nacional passavam, necessariamente, pela discussão a respeito dos efeitos da miscigenação. ${ }^{23}$ No entanto, a problematização da evolução da sociedade brasileira não foi feita em termos de raça no livro de Costa. Estão lá as referências às teorias racialistas, mas somente para fornecer dados para o autor construir as analogias entre sexo e raça, centrais na sua análise evolucionista.

A categoria principal do seu pensamento é o gênero. A tese defendida pelo autor é que a evolução dos indivíduos e da espécie humana ocorreu de maneira diferenciada para os dois sexos e que esta diferença deveria ser reduzida em benefício da evolução da sociedade. Portanto, para ele, o futuro da sociedade não dependia da questão racial, embora reconhecesse sua importância, mas sim da questão da mulher, da compreensão de sua natureza e do papel que deveria exercer. Ou seja, Castro aprendera bem as lições dos anatomistas e fisiologistas que produziram o que chamamos no primeiro capítulo de ciência sexual. Seu livro é, portanto, uma síntese das principais conclusões sobre as diferenças sexuais mapeadas pelos cientistas dos séculos XVIII e XIX, base material para justificar as hierarquias, as desigualdades e a legitimação do poder.

Como um intelectual bem informado, Castro explica que o tema era já bastante conhecido e vinha sendo abordado por diferentes autores, principalmente na literatura romântica. Contudo, esta abordagem incorria em erros por não se pautar pela verdade, distorcendo a história e ignorando a Ciência. A crítica de Castro referia-se ao endeusamento da mulher, à idéia de que ela seria a fonte da moralidade, das virtudes e dos sentimentos nobres, uma criatura superior, semidivina, inspiração dos homens para o progresso da civilização.

Em várias passagens do livro Castro se mostra avesso à idealização da mulher tal como Schopenhauer e outros misóginos do final do século XIX para quem a Ciência fornecia provas incontestáveis da inferioridade do sexo feminino. Não lhe agradavam as metáforas poéticas, muito menos as representações românticas de mulheres moralmente superiores aos homens. Estas não eram mulheres reais, mas criações da mente masculina, 
ilusões, imagens, resquícios do fetichismo; assim, o autor sublinhava que a Ciência, embora fosse um produto da mente humana, resultado de uma atividade mental superior, era produto da evolução cerebral do homem, portanto, avessa às atividades inferiores como a imaginação.

Seu livro propunha outra abordagem do tema, fundada única e exclusivamente na Ciência e na preeminência da verdade sobre qualquer outra intenção ou sentimento. Para Castro, a mulher real e a compreensão do seu papel na sociedade só podiam ser acessíveis ao conhecimento através da verdade incontestável da Ciência, fosse pela experimentação ou pela autoridade dos cientistas a que ele recorreu para construir sua análise. ${ }^{24}$

Partindo de um ponto de vista diferente dos médicos que escreviam sobre a mulher-mãe e o altruísmo feminino, Castro propôs outro modelo de análise: ao invés da moral, as verdades da fisiologia e da evolução; ao invés do modelo ginecológico, o modelo cerebral. Castro defendia as teorias que consideravam o cérebro o órgão mais importante do corpo humano, por ser a sede da inteligência e de todos os comandos sobre os outros órgãos, bem como dos fenômenos psicológicos.

Os estudos sobre o cérebro se prestavam muito bem à tarefa classificatória da ciência moderna porque criavam parâmetros estatísticos com os quais os cientistas procuravam dar um significado para as diferenças humanas; ou seja, as ciências biológicas e a medicina encontraram na matemática e na estatística as ferramentas para construir modelos explicativos e classificações cujo objetivo era ordenar hierarquicamente as diferenças. Procurou-se coletar o maior número possível de dados sobre o crânio e o cérebro humano e distribuí-los em séries ou quadros estatísticos para assim formular as premissas consideradas verdadeiras e passíveis de generalização. Todo o conhecimento citado por Castro partiu desta crença na positividade do fato observável e mensurável, núcleo material e inquestionável da verdade.

Tomando esse modelo de conhecimento como referência, Castro explica que seu estudo a respeito da mulher partia do órgão determinante de sua condição atual como indivíduo e como representante de metade da espécie humana. Entender o que era a mulher, explicar sua diferença em relação ao homem e estabelecer o prognóstico biológico e social eram atividades intelectuais que requeriam uma investigação do cérebro feminino. Dessa forma, sua abordagem reiterava uma verdade científica: conhecido o órgão estará conhecida a função. Cabe salientar como o autor, 
mesmo conhecendo a produção da medicina da mulher, inverte o pólo de sua análise, deixando de lado o determinismo ginecológico e se direcionando para o 'norte do corpo', para um órgão assexuado, mas considerado o mais importante na hierarquia biológica do corpo humano.

Todos os autores de que se cerca - Manouverier, Wagner, Topinard, Huscke e Broca - sustentam a inferioridade do cérebro feminino quando comparado ao masculino, fosse pelo peso, volume ou forma. As medidas do tamanho do crânio e do peso do cérebro eram consideradas provas inquestionáveis da inferioridade feminina, pois acreditava-se que o peso era a 'expressão matemática da riqueza encefálica'. Em contrapartida, os estudos de anatomia e fisiologia tinham estabelecido que as funções psíquicas mais importantes estavam localizadas nos lóbulos frontais, mais desenvolvidos nos homens das 'raças adiantadas'. O cérebro feminino apresentava as regiões laterais e posterior mais acentuadas, tal como os homens da pré-história e os criminosos, o que as colocava em um estágio evolutivo atrasado em relação aos homens. Já os antropólogos com suas 'coleções de crânios' confirmavam que em nenhuma sociedade havia crânios femininos mais desenvolvidos, o que levou Castro a afirmar que "o fato demonstrado pelo método desapaixonado das cifras é inegável, tem a generalização e a amplitude de uma lei: a mulher tem menos cérebro do que o homem" (Castro, 1893: 10).

Mas estas provas matemáticas e morfológicas não eram suficientes para a compreensão do fenômeno. O objetivo de Castro era afastar qualquer especulação sobre causas sociais e culturais na diferenciação cerebral entre os sexos que viessem questionar a determinação biológica dos enunciados científicos sobre a inferioridade feminina. Para tanto, o autor traça algumas linhas evolutivas procurando pelo início da diferenciação e como ela sempre indicava a superioridade masculina. A primeira destas linhas é embriológica e novamente os dados comparativos apontam para a menor capacidade cerebral da mulher, levando Castro a afirmar que estas diferenças são hereditárias. A outra linha é filogenética, obtida pela comparação com os antropóides, nos quais os cientistas encontraram a mesma superioridade craniana dos machos, de onde o autor conclui com mais um de seus enunciados com força de lei: "a evolução nos primatas é masculina" (1893: 14).

Todos os valores e comparações têm a força de prova, são representações matemáticas de uma lei biológica que explicava as assimetrias entre os sexos e as raças. Os argumentos de Castro, bem como a formulação de suas 
idéias, são exemplares do papel das analogias no conhecimento científico, ao criar novos significados para as diferenças, como se pode observar na construção do modelo cerebral adotado pelo autor para provar que a inferioridade feminina era uma decorrência da evolução diferenciada do cérebro, um fato da natureza e não da sociedade como acreditavam os 'defensores' da mulher.

Para o autor, as assimetrias sexuais presentes na sociedade nada mais eram do que a expressão de diferenças físicas, de antagonismos fisiológicos e anatômicos entre os sexos. Nesta formulação, o corpo é apresentado como uma federação de órgãos comandados pelo cérebro, um órgão assexuado, mas fundamental para entender as diferenças humanas observadas pelos cientistas. Castro explica que, na história da evolução da espécie humana, o cérebro era um órgão novo em comparação com a medula e os gânglios nervosos, no entanto, havia operado uma verdadeira revolução no desenvolvimento da humanidade. Entre os vertebrados e mesmo na espécie humana teria ocorrido um período em que a medula predominara, sendo posteriormente subordinada ao cérebro em suas funções devido à evolução. O mesmo processo evolutivo que ocorrera na espécie ainda se reproduzia na evolução dos indivíduos, ou seja, na ontogenia, como explica Castro, ao comparar o predomínio da medula nos embriões e nos recém-nascidos e o predomínio cerebral nos adultos. Assim, o que Castro procura estabelecer é um diferencial evolutivo entre a medula e o cérebro, associando estas duas estruturas a estados respectivamente primitivos e evoluídos.

A partir desta fundamentação fisiológica, Castro passa então a construir seu sistema analógico. Seguindo o seu raciocínio, se no homem predominava o cérebro, na mulher predominava a medula, e como estas duas estruturas eram consideradas antagônicas na sua evolução, explicavase, portanto, o antagonismo entre o homem e a mulher na sociedade.

Novamente, o autor ignora as discussões que eram travadas entre os ginecologistas da época a respeito do corpo feminino ser determinado pelo útero ou pelos ovários. Castro procura comparar órgãos que existem nos dois sexos, ou seja, mostrar que a evolução não se deu na mesma velocidade e direção para homens e mulheres, procurando provar que no jogo das semelhanças e diferenças foram estas que acabaram se impondo. Ante uma lei natural como a evolução cerebral não havia argumentos que pudessem clamar pela igualdade entre os sexos. 
As provas desta predominância medular na mulher eram fornecidas pela Ciência. Os craniologistas diziam que a mulher estava mais próxima das crianças e das raças primitivas na linha evolutiva do que do homem e como nestas últimas havia um predomínio da medula, estava criada a analogia. Alguns fisiologistas afirmavam conhecer o sexo de um indivíduo apenas observando as células medulares, pois nas mulheres elas seriam maiores, isto numa época em que os processos de mensuração celular eram pouco precisos. Lombroso e Ferrero (1923) forneceram outro dado, fortalecendo a idéia do antagonismo cérebro-medular entre homens e mulheres ao dizer que haviam encontrado, em alguns alienados e em indivíduos normais cuja constituição física os aproximava de uma organização feminina, uma sensibilidade meteorológica, isto é, alguns indivíduos se deixavam influenciar pelas alterações na pressão atmosférica, mudando seu comportamento. Para Lombroso e Ferrero, esta sensibilidade era antagônica à inteligência, sendo por isto mais freqüente nos dementes, idiotas e epilépticos, nos quais predominavam os centros ganglionares e a medula.

A conclusão de Castro é que a mulher também tinha a mesma sensibilidade, embora não apresente 'provas', concluindo que este fato era uma evidência de que a mulher representava o passado de uma espécie anterior à humana:

A mulher ainda conserva hoje no estado fisiológico os vestígios de uma espécie que deu a humana, espécie que como a Rana lemporaria sentia as mudanças meteorológicas. No homem o desenvolvimento cerebral extinguiu esta sensibilidade orgânica, mas o mesmo cérebro criou no termômetro e no barômetro meios extra orgânicos de sentir. (1893: 39)

Tem-se, portanto, a construção da representação da mulher medular, uma representação científica da inferioridade biológica e social do sexo feminino, parte integrante de um sistema dicotômico de pensamento que organiza hierarquicamente as coisas e as pessoas, conforme se pode observar nas duas colunas:

$\begin{array}{ll}\text { Cérebro } & \text { Medula } \\ \text { Cultura } & \text { Natureza } \\ \text { Raças Superiores } & \text { Raças Inferiores } \\ \text { Adulto } & \text { Criança } \\ \text { Inteligência } & \text { Emoção } \\ \text { Comando } & \text { Submissão } \\ \text { Homem } & \text { Mulher }\end{array}$


Os pares são dispostos para reforçar o antagonismo horizontal entre eles e, ao mesmo tempo, salientar a interação vertical, o que explica as analogias entre mulheres, crianças e 'raças inferiores', tão comuns no pensamento científico do século XIX.

Cabe ainda salientar como o autor construiu sua análise a partir da analogia entre gênero e raça. Castro procura criar similaridades entre as mulheres e os indivíduos pré-históricos ou seus descendentes no presente, as 'raças primitivas', aproximando suas características físicas e atribuindo-lhes significados e valores como a inferioridade e a passividade. Seu objetivo era provar que a evolução criara diferenças muito acentuadas entre as raças humanas e os dois sexos. Dessa forma, a mulher representava um estágio anterior da evolução em relação ao homem, equivalente às diferenças que os cientistas encontravam entre as raças. Tal criação de similaridades e diferenças levou Castro e outros cientistas da época a estabelecer analogias como 'raças femininas' ou 'povos infantis' e a afirmar que quanto mais adiantada e evoluída a raça, maior era a diferença entre homens e mulheres, pois o termo 'raça evoluída' era análogo ao desenvolvimento cerebral masculino.

É interessante observar como na construção das analogias científicas são selecionados alguns dados confirmadores das teorias racialistas e sexistas. Castro apresenta quadros do volume cerebral humano dispostos cronologicamente para comparar os dados com os valores encontrados para os antropóides. Sua conclusão é que, na espécie humana, o homem evoluiu numa velocidade maior que a mulher, apresentando uma diferença de $150 \mathrm{~cm}^{3}$ no volume cerebral. A mesma tendência foi encontrada nos crânios dos antropóides, ou seja, quanto mais acentuada a diferença sexual nos animais, maior o tamanho do crânio e mais acentuada a superioridade dos machos. Aqui pode-se perceber a influência marcante de Lombroso e Ferrero, especialmente no que se refere à comparação entre a evolução sexual dos animais e dos seres humanos. Em verdade, Lombroso e seus discípulos queriam reforçar as linhas demarcatórias entre a civilização e o estado da Natureza, usando a categoria gênero para 'provar' que somente nas espécies mais inferiores, como os vermes, insetos e aranhas, as fêmeas predominavam sobre os machos. Os cientistas transpunham com muita facilidade as relações de poder que hierarquizavam homens e mulheres para o reino animal, ou seja, em suas versões da evolução sexual, o poder dos machos era um índice confirmador de ascensão na escala que culminava com o homem civilizado. 
Mas o que significavam os $150 \mathrm{~cm}^{3}$ de 'adiantamento cerebral' nas relações entre os sexos e para a mulher em especial? Para Castro, este número significava maior poder mental, ou seja, quanto mais desenvolvido o órgão, mais desenvolvida a função, esta era a lei. Na sua interpretação darwinista, os mais aptos eram os mais inteligentes porque tinham cérebro maior; portanto, os homens eram mais inteligentes, tinham mais força $e$, conseqüentemente, poder sobre as mulheres. Estavam inscritas na natureza e na estrutura do cérebro as relações de poder entre os sexos.

Esse valor também foi de grande importância para a construção de outra representação da mulher muito divulgada pelos cientistas e intelectuais do final do século XIX: a mulher-criança. Nesse sentido, Castro se esforça para mostrar, por meio de vários gráficos, as curvas do crescimento cerebral para homens e mulheres. A linguagem dos números é traduzida como evidência de que desde o nascimento a mulher apresenta um volume cerebral inferior, encerrando a curva por volta dos 20 anos com um valor aproximado ao volume cerebral de um menino de dez anos. Destes dados, Castro completou sua conclusão: "a mulher tem menos cérebro que o homem e menos cérebro que um menino de dez anos", ou de forma mais concisa, "a mentalidade da mulher é a mentalidade de um menino" (1893: 98). Nem Schopenhauer teria expressado melhor a inferioridade cerebral feminina, uma idéia muito divulgada nos textos científicos e na literatura da época.

Um indivíduo com pouco cérebro, representante do passado de sua espécie e com mentalidade infantil não poderia ter desempenhado um papel significativo na evolução - era o que pensavam os cientistas e reiterava Castro. A partir desse momento, a análise do autor é direcionada para a seleção sexual, pois esta teria sido a única contribuição da mulher. Castro diz que desde os tempos pré-históricos a mulher teve seu destino ligado ao poder masculino. A mulher selecionava o homem mais forte, mais temido e mais apto. Esta seleção que permaneceu até a época dos guerreiros medievais seria a explicação para a atração sexual das mulheres pelos reis e homens poderosos: "Em toda a existência humana a mulher, guiada pelos seus interesses de ente fraco, tem sempre adorado a força física, a força muscular, para dizer mais cientificamente" (1893: 116).

Essas passagens sobre a suposta atração sexual pelo poder masculino, que uniu africanas, russas, francesas e esposas de barões do café, são usadas pelo autor para sustentar que se a seleção sexual feminina prevalecesse na evolução, não se teria chegado à civilização moderna - dos 
termômetros, barômetros, da democracia e das obras de arte -, mas permaneceria o estágio medieval. Como as mulheres não evoluíram, Castro (1893: 119-120) explica a subordinação feminina no presente como uma condição adquirida e transmitida por herança genética:

Submetida à escravidão desde a mais remota antiguidade, submetida a uma verdadeira seleção natural em parte artificial, tornou-se submissa por tradição, escrava por hereditariedade e quando teve por sua vez que proceder à seleção, à escolha, procurou no homem um senhor. Uma escravidão de muitos mil anos é mais que bastante para fazer do servilismo uma tendência orgânica, 'inata', e foi essa a escravidão da mulher.

A naturalização das relações de poder foi um procedimento intelectual usado tanto para legitimar as relações de gênero marcadas pela assimetria e a desigualdade, como também para sustentar o colonialismo, pois o mesmo raciocínio sobre o 'amor aos poderosos' era aplicável para as relações entre os europeus e as 'raças inferiores' da África e da Ásia. Dessa forma, as mulheres e os povos não civilizados tinham mais uma semelhança que os aproximava: a submissão adquirida ao poder masculino.

Castro não esconde sua admiração pelo homem evoluído mentalmente. Suas características físicas, intelectuais e morais o colocavam acima de outros homens - os negros, os asiáticos e os pobres - das mulheres e das crianças. Descreve-o como o criador da cultura, uma "bela organização consciente", um ser livre por não pertencer a ninguém. Contudo, o homem evoluído pertence a uma minoria, diz Castro, certamente referindo-se a um grupo de eleitos pela evolução como os cientistas que povoam seu livro. Como um herói, o homem evoluído vivia distante das multidões, incompreendido quando mesmo desconhecido por elas. O descompasso entre a genialidade do homem evoluído e a multidão era de tal magnitude que as suas idéias só seriam compreendidas um ou dois séculos depois. Segundo Castro esta diferença entre o indivíduo genial e as massas não resultava de oportunidades desiguais no acesso à educação, mas apontava para o fato de que havia idéias incompatíveis com cérebros ainda pequenos demais para entendê-las.

Como um evolucionista convicto do aprimoramento das espécies, Castro acreditava que na sua época esta diferença já começava a diminuir com a presença dos 'tipos intermediários' entre os homens muito evoluídos e a multidão, capazes de ser compreendidos e de contribuir para a elevação das massas populares. Castro vê na educação uma poderosa força evolucionista, especialmente na sociedade moderna que ele caracteriza pelo 
industrialismo, pela liberdade de expressão, ascensão social por mérito pessoal, consciência da evolução e relativismo. Nessa sociedade racionalizada havia demanda de cérebros, e somente a educação podia contribuir para a continuidade da evolução.

É o tema da educação que o leva a refletir sobre o papel da mulher na sociedade. Dentro da sua visão determinista, os níveis biológico, intelectual e social estavam dispostos numa rede de causa e efeito. Da mesma forma que Castro atribuía à natureza e à evolução a causa das radicais diferenças físicas e intelectuais entre os sexos, aplicava o mesmo determinismo biológico-sexual à organização da sociedade, defendendo a idéia de que às diferenças sexuais correspondiam diferenças sociogênicas. Dessa forma, devido ao cérebro menor e à medula desenvolvida, a mulher permaneceu num período mitológico da evolução mental, e esta seria a explicação para a religiosidade feminina, segundo o autor, afeita ao culto aos santos, à crença nos espíritos e demônios, representando social e psicologicamente a infância da humanidade. O papel da mulher na sociedade era, portanto, transmitir seu tipo psicológico e social do passado, uma força conservadora e estática que estava em contradição com a força dinâmica masculina. Esta era uma verdade que os reformadores sociais não podiam desprezar. Era necessário harmonizar estas duas forças em benefício dos indivíduos, mas principalmente da sociedade e da espécie humana; desse modo, Castro revelava-se um evolucionista meliorista, crente na capacidade transformadora da educação.

Se a mulher era psicologicamente uma criança e representava um tipo social mitológico e conservador, era necessário mudar sua educação para que no futuro, graças à hereditariedade, ela evoluísse mentalmente. Castro discorre sobre as condições em que as mulheres eram educadas tomando como referência o Brasil. Da mesma forma que Jaguaribe Filho, Tobias Barreto e outros intelectuais que denunciavam o descaso com a educação no país, Castro não poupou críticas ao governo brasileiro com a falta de uma política voltada para o bem-estar da população, especialmente no que se referia à saúde e à educação. Tal desinteresse era visível pela ausência de informações, pois não havia a prática sistemática de estatísticas populacionais, o que dificultou bastante o trabalho de Castro sobre a educação feminina: "Um governo sem demografia é um observador sem olhos, ou mais exatamente, um observador que tem todos os sentidos embotados" (1893: 193). 
Essa falta de 'espírito científico' e de interesse pela população colocava o país em uma zona escura, inacessível a pesquisadores como ele, que não tinham informações sobre a mortalidade, sobre a 'capacidade craniana' dos brasileiros, a criminalidade, o crescimento populacional, a ilegitimidade, o aborto, enfim, todas as estatísticas populacionais que forneciam os elementos necessários para a construção das ciências biológicas e sociais, tarefa para poucos interessados como Castro.

A educação no Brasil era digna de lástima e merecedora de condenação. Castro explica que em todos os países a educação feminina, baseada na memorização e nas prendas domésticas, não era comparável à masculina devido ao baixo nível de instrução que recebiam. No Brasil, nem isto havia, considerando-se o conjunto da população, sendo os homens muito ignorantes e as mulheres mais ignorantes do que eles, constatava o autor. Recorrendo ao relatório oficial de 1877, Castro chegou à conclusão de que somente $18 \%$ dos homens brancos e livres eram alfabetizados e somente $7 \%$ das mulheres, o que o levou a questionar se o Brasil podia ser considerado um país civilizado.

É interessante observar a extensão da análise do autor sobre o assunto, que deixa um pouco de lado o determinismo biológico e aprofunda a crítica social ao apontar as diversas causas do quadro desolador que se apresentava. Suas críticas mais duras são para o governo, que não teria alterado em nada a educação das crianças, permanecendo os mesmos padrões da época colonial. Também se volta para os pais, que, segundo sua análise, não reconheciam o valor da educação, especialmente os pobres, que preferiam ver seus filhos trabalhando desde pequenos. A escola também recebe suas críticas, pois não oferecia uma educação atraente para os alunos, com sua pedagogia rotineira e 'embolorada' e os 'excessos de latim'. Por fim, Castro critica a 'classe agrícola', considerada por ele como responsável pelo envenenamento intelectual do país devido ao seu parasitismo, à indolência e a uma visão de classe utilitarista do progresso. É o Castro (1893: 249-250) descendente de escravos e consciente das desigualdades sociais que escreve:

Acostumada à indolência a classe agrícola deixou-se ficar na bagagem da humanidade; só teve uma idéia, uma monomania - o café. Quando falamos na necessidade de progredir, ela diz que é preciso não gastar o lucro do café! Quando queixamo-nos por não ter direito à civilização, ela diz que é preciso não seguir sonhos inúteis com prejuízo do café (...) quando pedimos cérebros para este povo que não pensa, ela pede braços para cultivarem o café (...). A classe agrícola não representa a sociedade brasileira. Ela não se 
aplica à ciência que centuplicaria os benefícios, porque a ciência exige atividade e trabalho; ela ignora e nem ao mesmo sabe de sua ignorância. Ela compromete-nos, envergonha-nos, retém-nos em um estado equivalente ao da primitiva barbárie (...). Compreende-se que em um meio como este a educação da mulher deve ser absolutamente nula (...). O Brasil constitui atualmente um meio absolutamente impróprio para a evolução intelectual da mulher.

Essa passagem demonstra as contradições de autores com o perfil sociorracial de Castro. Como médico e cientista, é determinista, negando a possibilidade da interferência da subjetividade no 'destino' biológico das pessoas por terem nascido mulheres, negros, pobres ou numa ilha do Pacífico Sul. Como indivíduo que sofreu discriminações por causa de sua cor e por 'ousar' freqüentar os espaços sociais dos brancos, era impossível não perceber as desigualdades sociais e o descaso das autoridades brasileiras comprometidas com os interesses das elites, ou da 'classe agrícola', como as definiu Castro. Para aplacar estas contradições, o autor recorre ao seu refúgio racionalista, usando os mesmos modelos explicativos da teoria da evolução, atribuindo a uma ação social, como a educação, um poder evolutivo.

No entanto, quando retoma a discussão sobre a educação da mulher retoma também os argumentos deterministas. Se a hereditariedade e as condições sociais haviam confinado a mulher ao passado, era inadmissível que ela tivesse qualquer papel na educação das crianças, pois seria o equivalente a deixar uma criança educar outra, ou por analogia, confiar a educação da infância a um australiano, referindo-se às populações autóctones da Austrália. Contudo, sua crença na evolução o tornava um defensor da educação feminina, aproximando-o das demandas feministas e de intelectuais como Tobias Barreto.

Se Castro era um determinista para explicar as diferenças sexuais, acreditava que o meio podia alterar o estado mental da mulher. Dessa forma, não via nenhuma objeção à educação feminina; ao contrário, defendia sua necessidade para que a evolução continuasse, tendo em vista que a divisão sexual era tão profunda quanto as divisões raciais. Não concordava com seus contemporâneos a respeito do lugar da mulher na sociedade: "No ponto a que chegamos não basta como em outros tempos que a mulher seja mãe. E se basta ser mãe, a maternidade não está mais nas dores da parturição, que o progresso médico talvez venha suprimir; não está nos sacrifícios que a classe abastada não conhece" (1893: 338). 
Castro não estava defendendo uma educação liberal para que a mulher exercesse qualquer profissão ou fosse uma intelectual como ele. Longe disto, o que defendia era o mesmo que outros médicos preocupados com o papel social da mulher: uma educação voltada para a formação dos filhos. Dessa forma, Castro via na educação feminina uma forma de melhorar no sentido genético, ou melhor dizendo, sociogenético - a formação dos indivíduos e incrementar a velocidade da evolução, o que o aproxima ideologicamente dos obstetras e higienistas cujo reformismo conservador visava, tão-somente, a reforçar o modelo hierárquico da família nuclear chefiada pelo marido empreendedor e a esposa empenhada em transformar seu lar no 'refúgio do guerreiro', idéia esta que revela a continuidade de um discurso formulado por intelectuais reformistas europeus desde meados do século XVIII. ${ }^{25}$

Comparado aos seus contemporâneos, Castro compartilha a mesma visão pragmática sobre o papel da mulher na sociedade, embora secundarize a maternidade, não restringindo a questão exclusivamente à reprodução ou à transmissão de valores morais, como era típico dos outros discursos sobre as funções da mulher-mãe na época. Como cientista e evolucionista, reconhecia a importância social da maternidade, mas não via o seu exercício como um fim em si mesmo. Ele levava muito a sério a noção de complementaridade sexual e exatamente por este motivo defendia a evolução mental da mulher. Rejeitava as idéias que estabeleciam a família como o lugar da mulher e a sociedade como o do homem, pois ambos deviam cooperar nas duas esferas, mantendo, evidentemente, a divisão sexual do trabalho, pois Castro não concordava com a igualdade de acesso às atividades profissionais e políticas.

Para que a evolução da espécie fosse mais fácil e rápida, os dois sexos tinham de se associar e isto significava aproximar a mulher do homem no que diz respeito à sua formação intelectual. Divididos como duas raças não conseguiriam incrementar a evolução da sociedade e da própria espécie. Portanto, a reprodução e a evolução deviam ser, no futuro, tarefas dos dois sexos igualmente, ou pelo menos não deviam ser antagônicas.

As idéias de Castro sobre a mulher são reveladoras de como se deu a apropriação das teorias e doutrinas em voga no século XIX, bem como da ambigüidade presente neste processo intelectual, como observou Margareth Rago (1991). Leitor de autores como Lombroso, Spencer, Schopenhauer, de antropólogos e craniologistas, Tito Livio de Castro produziu o único livro 
brasileiro sobre a ciência sexual no século XIX. Ele foi, nesse sentido, um intérprete das teorias que procuravam explicar a diferença sexual feminina para justificar, mediante o processo de naturalização, as diferenças que foram criadas e legitimadas pela sociedade. O que distingue o livro de Castro de outras publicações sobre o assunto que analisamos anteriormente é o fato de que ele passou ao largo da medicina da mulher, o que demonstra que, no que dizia respeito à questão, não havia teoria única adotada por todos os envolvidos no debate.

No Brasil, especificamente, não houve por parte dos obstetras e ginecologistas disposição em envolver-se publicamente com temas como a educação superior para as mulheres, como ocorreu nos Estados Unidos. Isto se deve ao fato de que não houve aqui especialistas na mulher pelo menos até a década de 1870, devido à precariedade do ensino médico, conforme vimos. Em contrapartida, os obstetras e ginecologistas estavam mais voltados para a profissionalização e o reconhecimento de suas especialidades do que para polêmicas como o voto feminino ou a educação superior, mesmo porque estas reivindicações só tiveram visibilidade no país no início do século XX. Há também que se destacar que estes especialistas não construíram espaços próprios de debates, com exceção das oportunidades para expor casos ou novas terapêuticas na Academia Imperial de Medicina. Até 1908 não havia uma publicação específica das especialidades obstétrica e ginecológica como havia em número cada vez maior nos Estados Unidos, na Inglaterra, na França e na Alemanha.

Embora médicos como Werneck de Almeida, Rodrigues dos Santos, Fernando Magalhães, Climério de Oliveira e José Adeodato não tivessem dúvidas de que a ciência da mulher tinha descoberto a verdade sobre a sua natureza e os meios para reconduzi-la ao seu caminho quando ultrapassasse a linha tênue que separava a normalidade da patologia, não se mostraram muito afeitos a extrapolar o meio médico e a clínica. Seu objetivo não era a liça retórica ou política, mas conquistar legitimidade e clientes dispostas a seguir suas orientações.

Talvez esses fatores expliquem por que um livro sobre a natureza feminina e seu papel na evolução da sociedade não tenha sido escrito por um ginecologista ou obstetra, mas por um jovem médico que se interessava por estudos neurológicos e psiquiátricos. Para Castro, os órgãos reprodutivos da mulher não tinham tanta importância quanto para os ginecologistas, pois sua análise estava fundamentada no órgão que para ele e para os 
craniologistas era mais nobre e determinante para os indivíduos e para a espécie: o cérebro. As diferenças entre homens e mulheres deviam ser procuradas neste órgão, pois o útero e os ovários nada mais representavam do que órgãos reprodutivos. As diferenças mais importantes que faziam homens e mulheres parecerem tão distintos quanto as raças estavam inscritas nos cérebros como mostrava o 'método desapaixonado das cifras'.

Contudo, as divergências de método e de ênfase na anatomofisiologia de um ou outro órgão não impediam que os médicos compartilhassem das duas teses centrais de todos estes estudos: a de que as mulheres não podiam se autorepresentar, sendo necessário que os homens da ciência as transformassem em objetos de estudo, emitindo a verdade sobre elas; e a impossibilidade de qualquer intervenção das mulheres em um destino comandado pela lei da evolução ou pela tirania de seus órgãos reprodutivos, que as transformavam em verdadeiras prisioneiras das cadeias do próprio corpo.

Se observarmos a longa trajetória da constituição dos discursos médico e científico sobre a mulher, veremos que sua autoridade, bem como a verdade que difundiam, nem sempre foram aceitas com facilidade. Outros discursos se opuseram ao determinismo científico - como vimos com Tobias Barreto -, questionando seus argumentos factuais e quantitativistas. Homens e mulheres envolvidos com a 'questão da mulher', tanto nos países europeus como do outro lado do Atlântico, podiam ser minoria, mas não se calaram, desvelando os preconceitos presentes na elaboração do discurso médico e das teorias científicas a respeito das diferenças sexuais.

Tomados em conjunto, os discursos produzidos pela ciência sexual e pela medicina nos revelam um tipo de escrita masculina sobre seu objeto, a mulher, esta criatura gerada na imaginação e na racionalidade e apenas parcialmente em evidências das mulheres de carne, osso, útero, ovários e cérebro que eles pretendiam explicar. São narrativas masculinas mescladas de racionalidade e imaginação sobre este 'eterno outro' da cultura ocidental.

\section{Notas}

1 Cabe observar que entre os membros do Instituto Histórico e Geográfico Brasileiro havia um número expressivo de médicos. Ver em Scliar (1996).

2 Sobre o projeto da reforma higienista da sociedade brasileira, ver Costa (1979); Machado et al. (1978). Sobre o caráter ideológico da reforma higienista, ver Chalhoub (1996).

3 Sobre Afrânio Peixoto, ver Mota, Lopes \& Cóser (1994) e Hershmann \& Pereira (1994). 
4 Comentário de Alceu Amoroso Lima (apud Mota; Lopes \& Coser, 1994) sobre o livro Fruta do Mato, de Peixoto.

5 Sobre a proximidade da literatura com a ciência e a medicina no romance naturalista, ver Sussekind (1984).

6 Tomo como referência os estudos de Donzelot (1986), Costa (1979) e Joseph (1977).

7 Sobre o discurso iluminista a respeito da mulher-mãe tomo como referência os trabalhos de Badinter (1985) e Hoffman (1976).

8 A referência a Gendrin está na coletânea organizada por Leite (1984).

9 Sobre Coutinho, ver Reis (1998), Castro (1977) e Reis (2000).

10 Ver em Agassiz \& Agassiz (1975).

11 Cabe aqui comentar que a imprensa feminina do século XIX não se restringiu a defender a educação feminina unicamente para que as mulheres fossem boas mães, mas principalmente para melhorar seu status social e defender seus direitos. De qualquer forma, mesmo tendo uma visão mais ampla da condição feminina na sociedade brasileira, incentivava-se o papel da mulher mãe, realçando a importância de educar a mulher para que ela transmitisse este saber à sua prole, cumprindo integralmente sua missão. Sobre a imprensa feminina, ver Hahner (1981).

12 Ver em Blake (1893).

13 É interessante notar como a masculinização da criança teve uma grande inserção no âmbito médico e intelectual, permanecendo até mesmo em livros que surgiram como uma reação à ortodoxia médica, como o famoso livro do Dr. Leboyer (1979). Neste livro a criança é do sexo masculino e a descrição que o autor faz do parto é de uma luta entre o corpo-prisão da mãe e o corpo da criança que busca libertar-se. O bebê é descrito como 'Ulisses', 'herói', 'argonauta', 'menino-rei', 'menino divino', revelando um encantamento pela masculinidade que os antecessores do autor não tiveram coragem de expressar assim tão abertamente.

14 "Menino que custa a nascer, quando nasce está todo estragado. Se nasceu arroxeado ou custa a chorar, escolhe-se uma pena macia no "rabo" da galinha e se futuca o nariz dele. Quando o menino nasce feito morto, esfrega-se o corpo todo com álcool e deita-se de barriga para baixo. Enquanto isto, manda-se esquentar uns tijolos e se põe em volta dele para a quentura chamar a reação." (Parteira Belinha apud Vianna, 1978: 31).

15 Ver Barreto (1977: 320).

16 Ver "Notas a lápis sobre a evolução emocional e mental do homem" (Barreto, 1962).

17 "Educação da mulher" - Assembléia de Pernambuco. Sessão de 22 de março de 1879 (Barreto, 1977: 338).

18 "A alma da mulher" - Sobre a conferência de Jellinek em 1873. Barreto deu o mesmo título, acrescentando a informação sobre a autoria da conferência (Barreto, 1977: 316).

19 A primeira brasileira a obter o título de doutora em medicina foi Maria Augusta Generoso Estrela, natural do Rio de Janeiro, formando-se em 1881 no New York Medical College, tendo sido muito elogiada pela imprensa carioca e recebida pelo imperador, que foi seu protetor, financiando parte de seus estudos nos Estados Unidos. Ver Silva (1954). 
2) Ver Magaldi (apud Costa \& Bruschini, 1992).

21 As informações biográficas de Tito Livio de Castro foram coligidas do prefácio escrito por Silvio Romero.

2 Schwarcz (1993).

23 Sobre a questão racial no meio intelectual brasileiro no século XIX, ver Corrêa (1982); Schwarcz (1993); Skidmore (1976) e Azevedo (1987).

24 Sobre as representações românticas da mulher na literatura, ver Ribeiro (1996); Marco (1986).

25 Algranti (1996: 252-266). 


\section{Conclusãa}

O corpo feminino tem uma célula de noite arcaica. É um lugar secreto e sagrado. A mulher é um vaso lacrado, um santuário. Tudo que é sagrado suscita profanação.

Malcom Montgomery (1997: 53)

Entre os séculos XVIII e XIX a mulher passou a ser o tema que foi formulado e investigado no interior de um amplo debate cultural mais conhecido como a 'questão da mulher'. Até então, a mulher não era entendida como objeto de maiores atenções, porque a tradição ocidental filosófica e religiosa havia estabelecido que se tratava de um ser imperfeito, tanto na sua natureza - um macho imperfeito, como sentenciou Aristóteles - quanto na sua constituição moral, afinal fora a primeira mulher a responsável pela perda do Jardim das Delícias, sentenciada por Deus a parir em dores e a ser dominada pelo homem.

Os filósofos, os naturalistas e os médicos setecentistas, todos otimistas em relação à capacidade humana de transcender sua condição de menoridade em direção à liberdade e à felicidade, não podiam continuar repetindo as velhas máximas misóginas. Descobriram na outra metade da espécie humana particularidades, finalidades, diferenças que precisavam ser conhecidas, explicadas e organizadas no amplo inventário da Natureza e da sociedade empreendido pelos homens das Luzes.

Nesta visão otimista da Natureza e da humanidade, a mulher continuava a ser vista como inferior ao homem; contudo, foi reabilitada a 
partir de sua natureza, como parte complementar do homem nas transformações inevitáveis que afetariam os indivíduos, as instituições e, conseqüentemente, a sociedade. Para os philosophes e os naturalistas a Natureza não havia criado um ser imperfeito sem uma finalidade. A partir disso, procuraram explicar qual seria esta finalidade e a encontraram no corpo feminino. Se ao homem racional cabia a condução dos destinos das sociedades e a compreensão das leis naturais, à mulher corporal cabia uma responsabilidade não menos importante, a geração e a criação dos filhos; transformaram, assim, a potência natural do corpo feminino numa força emocional e moral agregadora da família.

Esta nova visão moralizada e ao mesmo tempo naturalizada da mulher é tributária dos novos conhecimentos anatômicos e fisiológicos que tiveram lugar no século XVIII, origem de um novo campo de conhecimentos que se configurou no século XIX: a ciência sexual. Este novo saber procurou explicar as diferenças humanas a partir de um modelo materialista e naturalista, contornando a espinhosa questão da igualdade que esbarrava nas relações de poder, entre elas as relações de gênero. O domínio masculino carecia de explicações empíricas e estas foram procuradas e 'encontradas' na materialidade dos corpos femininos.

Nesse sentido, os anatomistas e fisiologistas do século XVIII não inovaram nas explicações, mas somente no método das investigações. Continuaram, de certa forma, a tradição misógina, só que diferentemente de seus antecessores, encontraram no corpo feminino sinais, não de uma imperfeição, mas de uma radical alteridade em relação ao homem. Tal diferença foi interpretada como o sinal indelével de uma natureza feminina marcada ora pelo excesso, ora pela falta, como demonstram os estudos do esqueleto humano, cujas representações são muito mais confirmações da ordem social e dos conceitos de feminilidade e masculinidade do que do resultado das observações de corpos dissecados.

Os cientistas do século XIX não só deram continuidade a este inventário das diferenças sexuais como ampliaram consideravelmente o escopo de suas pesquisas sobre a natureza da mulher, afinal as lições revolucionárias do final do século XVIII sobre as pretensões femininas pela igualdade recolocaram a 'questão da mulher' em um outro patamar ideológico no que diz respeito às relações de poder.

O longo processo de enclausuramento das mulheres das elites e da burguesia no lar não ocorreu somente nos domínios jurídico e econômico, 
mas contou com a valiosa colaboração dos estudiosos e especialistas da mulher, especialmente os médicos. Se alguém se dispusesse a fazer um balanço de todos os escritos da tradição ocidental sobre a questão, certamente perceberia que a curva exponencial se acentua durante o século XIX. Cientistas, médicos, romancistas, poetas, ensaístas, sociólogos, historiadores e moralistas produziram uma vasta documentação sobre o feminino, resultando em um saber heterogêneo, mas contínuo, dando origem a uma nova criatura: a Mulher.

Ao longo deste livro, procuramos mostrar como esta criatura onipresente e totalizante pouco ou nada tinha a ver com as mulheres e suas diferenças sociais e culturais. As criaturas do século XIX - lembremos do Dr. Frankenstein - resultam de ansiedades e ambições de homens que acreditavam poder dominar a Natureza e também outros homens e mulheres considerados menos evoluídos. Os saberes constituídos no século XIX não só explicavam o mundo e as coisas, mas produziam individualidades, nominavam espécies e raças, discriminavam os seres que aparentemente pareciam se ocultar na indiferenciação caótica da Natureza e das sociedades.

Os estudos sobre a natureza feminina, cujas origens e motivações foram investigadas neste livro, mostram, em primeiro lugar, como os saberes produzidos pela ciência sexual e pela medicina da mulher têm como motivação a redefinição política das relações de gênero e também a curiosidade gerada pela ansiedade masculina em explicar a mulher. A questão do enigma e do mistério em relação ao Outro - no caso, o outro feminino - levou à produção de representações alegóricas e poéticas, criadoras de mitos como a mulher inatingível, a musa inspiradora, a mãe amorosa e tantas outras criações da imaginação artística e literária, por exemplo. Mas a mesma atitude de conhecer este Outro cercado de mistérios pode gerar suspeitas que vão das teorias da fragilidade e inferioridade feminina à satanização da mulher. Seja como ser etéreo e fonte da beleza e da bondade, seja como fonte de poluição e de degeneração, a criatura Mulher que foi produzida nos textos e imagens de uma cultura masculina nunca deixou de suscitar curiosidade e alimentar a imaginação criadora dos homens.

Entre esses homens analisamos os especialistas da Mulher. A partir do sutil mecanismo da naturalização das diferenças sexuais e de gênero, coube aos médicos uma dupla função: explicar como e por que as mulheres são mulheres e ajudá-las a saber viver de forma a atender aos ditames da 
Natureza. Para os médicos oitocentistas, o enigma da Mulher estava no corpo, fonte do bem e do mal, dependendo de como elas se adequavam ao modelo 'normal' estabelecido pelos cientistas e pelos próprios médicos, cada vez mais voltados para o bem viver das pessoas e não apenas para as doenças.

Se a ciência sexual havia estabelecido que a principal diferença entre homens e mulheres residia no predomínio da razão entre aqueles e do corpo e das emoções entre estas, a medicina da mulher vai além ao afirmar que a Mulher é prisioneira do seu corpo, e que este, por sua natureza, é instável e nervoso.

Como os saberes geram novos saberes, os especialistas nos mistérios do corpo feminino criaram novos métodos e instrumentos de observação para ver melhor ou mais internamente, sempre na ânsia de conhecer mais e quiçá tudo sobre o Outro feminino. Dessa forma, enunciaram a verdade sobre sua criatura, uma verdade política que se apresentou sob a chancela da Ciência.

Não negamos que os conhecimentos e as técnicas criadas pela obstetrícia e a ginecologia tenham contribuído para a melhoria das condições físicas das mulheres, ou seja, não defendemos uma atitude a priori anticientífica em nossa crítica à ciência sexual e especialmente à medicina da mulher. Certamente que o uso de anestésicos nos partos, o desenvolvimento de técnicas cirúrgicas mais seguras, entre outras inovações, foram benéficas e bem-vindas. Contudo, a questão não pode ser vista somente a partir do desenvolvimento ou do progresso da ciência e da medicina, mas a partir da natureza das relações que se estabelecem entre aqueles que produzem o saber e aquelas que são alvo ou objeto de tal conhecimento. Estas relações são, na verdade, políticas, em primeiro lugar, porque se constituem a partir de uma cisão epistemológica fundamental: a escrita prolífica sobre o corpo silencioso, que, como bem expressou Afonso Romano de Sant'Anna (1984), revela o poder lingüístico dos homens. Em segundo lugar, porque a criatura médico-científica Mulher, como um fantasma, exerceu, e ainda exerce, sua influência sobre a vida e as escolhas das mulheres ao serem definidas como seres instáveis, seja pelo império dos seus órgãos reprodutivos, seja pelos hormônios, seja por qualquer outra particularidade do corpo feminino que ainda está por ser descoberta pelos cientistas.

Para escrever este livro, tivemos de entrar em contato com uma prolífica escrita masculina sobre a feminilidade, e este empreendimento nos fez lembrar de uma observação de Virgina Woolf a respeito da criação 
- a Mulher - e não das mulheres reais e de suas diferenças: ler tais livros não nos esclarece nada ou muito pouco sobre as realidades femininas nem sobre as experiências das mulheres com seus corpos, seus desejos, suas dores e seus prazeres. Como as mulheres não tinham as condições favoráveis para escrever, que, segundo Woolf, são, fundamentalmente, liberdade para pensar e dinheiro para se manter, elas ficaram à parte, como tantos Outros, da cultura masculina ocidental, da tradição escrita, mas não alheias a ela - tiveram o seu lugar como objetos, como representações e como criações silenciosas sobre as quais a imaginação masculina pode exercitar sua curiosidade e aplacar, mesmo que temporariamente, a sua ansiedade. 


\section{Referências Bibliográficas}

\section{FONTES MANUSCRITAS}

Arquivos no Rio de JAneiro

$\checkmark$ Academia Nacional de Medicina

Memórias dos médicos

Pasta 146 - Dr. Érico Coelho

Pasta 200 - Dr. Luiz Honório Vieira Souto

Pasta 207 - Dr. Francisco Werneck de Almeida

Pasta 215 - Dr. Fernando Magalhães

$\checkmark$ Arquivo Geral da Cidade do Rio de Janeiro

Petições, ofícios e mapa demonstrativo do movimento de partos da Maternidade Santa Izabel $(1877,1880,1881,1882,1889)$

Códice 46-2-32 - Maternidades e Casas de Saúde

\section{$\checkmark$ Arquivo Nacional}

Ofícios da Faculdade de Medicina do Rio de Janeiro ao Ministério do Império (1872 - 1884) - IS ${ }^{39}$ Ministério do Império

Ofícios da Provedoria da Santa Casa de Misericórdia ao Ministério do Império (1880-1884) - IS ${ }^{3} 9$ Ministério do Império - Santa Casa de Misericórdia

Orçamento, regulamento interno e planta do edifício da Maternidade Santa Isabel (1880-1889) - IS 29 Ministério do Império - Maternidade Santa Izabel

$\checkmark$ Hospital Pró-Matre

Livro de Observações da Clínica Obstétrica - 1919 


\section{Arquivos em SALVAdor}

$\checkmark$ Arquivo Geral da Universidade Federal da Bahia

Livros de Registro Clínico da Maternidade Climério de Oliveira (números 2 e 3)

$\checkmark$ Arquivo da Santa Casa de Misericórdia de Salvador

Livro de Portarias e Ordens da Mesa da Santa Casa de Misericórdia dirigidas ao Administrador do Hospital da Caridade (1847-1853) Memorial da Medicina Brasileira da Universidade Federal da Bahia - Terreiro de Jesus - Galeria dos Retratos dos Professores Falecidos (1808-1942)

\section{FONTES IMPRESSAS}

RELATÓRIOS

Relatórios da Santa Casa de Misericórdia do Rio de Janeiro (1879-1880)

Relatórios da Santa Casa de Misericórdia de Salvador (1886-1921)

Relatório Geral da Universidade do Paraná (1915)

REVISTAS E BOLETINS

Actas Ciba Ano XVII, n.10, dezembro de 1950

Boletim da Pró-Matre (1938-1940)

Renascença. Revista Mensal de Letras, Sciencias e Artes. Ano I, n. 1, Março de 1904.

Revista do Instituto Histórico e Geográfico Brasileiro, volumes 35, $74,260,328$ e 334

Revista de Ginecologia e Obstetrícia do Rio de Janeiro

Ano I, n. 2, setembro de 1907

Ano I, n. 4, novembro de 1907

Ano I, n.5, dezembro de 1907

Ano I, n.7, fevereiro de 1908

Ano I, n.8, março de 1908

Ano I, n.9, abril de 1908

Ano I, n.11, junho de 1908 
Ano I, n.19, maio de 1908

Ano II, ago.-dez. de 1908

Ano III, n.12, dezembro de 1909

Ano VII, n.9, setembro de 1913

Ano VIII, n.2, mar.-abr. de 1914

Ano VIII, n.3, maio-jun. de 1914

Ano XI, n.12, dez. de 1917

Ano XII, n.1, jan. de 1918

Ano XII, n.2, fev. de 1918

Ano XII, n.7, jul. de 1918

Ano XII, n.8, ago. de 1918

Ano XII, n.9, set. de 1918

Ano XII, n.10, out. de 1918

Ano XII, n.11, novembro de 1918

Ano XII, n.12, dezembro de 1918

Ano XIII, n.1, janeiro de 1919

Ano XIII, n.2, fevereiro de 1919

Ano XIII, n.3, março de 1919

Ano XIII, n.4, abril de 1919

Ano XIII, n.7, julho de 1919

Ano XIV, n.5, maio de 1920

Ano XIV, n.10, outubro de 1920

Ano XVIII, n.12, dezembro de 1924

Ano XIX, n.2, fevereiro de 1925

Ano XIX, n.3, março de 1925

Ano XIX, n.11, novembro de 1925

Ano XX, n.1, janeiro de 1926

Ano XX, n.6, junho de 1926

Ano XX, n.8, agosto de 1926

Ano XXII, n.11, novembro de 1928

Ano XXII, n.12, dezembro de 1928 


\section{TESES}

ADEODATO FILHO, J. O Ensino da Clínica Obstétrica na Universidade da Bahia, 1967. Tese, Salvador: Universidade Federal da Bahia.

ARAUJO, D. O. de. Republicanismo e Classe Média em Salvador - 1870-1889, 1992, Dissertação de Mestrado em Ciências Sociais. Salvador: Universidade Federal da Bahia.

ARAÚJO, P. A. N. Loucura Puerperal, 1883. Tese, Rio de Janeiro: Faculdade de Medicina do Rio de Janeiro.

ATHAYDE, J. L. La Ville de Salvador au XIX siècle: aspects démografiques d'apès les registres paroissiaux, 1975. Paris: Thèse de doctorat présentée a l'Université de Paris X.

BARROS, C. B. S. Dissertação sobre as Simpatias do Útero com outros Órgãos da Economia Animal, 1840. Tese, Rio de Janeiro: Faculdade de Medicina do Rio de Janeiro.

BAPTISTA, H. J. A Mulher e Medicina Legal, 1909. Tese, Bahia: Faculdade de Medicina da Bahia.

BELLINI, L. Representations of the Human Body in Sixteenth-Century Portugal, 1991. Tese, Colchester: University of Essex.

CARVALHO, F. T. Da Menstruação, 1914. Tese, Bahia: Faculdade de Medicina da Bahia.

CASTRO, D. D. B. Idéias Filosóficas nas Teses Inaugurais da Faculdade de Medicina da Bahia. 1838-1889, 1973. Dissertação, Salvador: Universidade Federal da Bahia.

CORDEIRO, J. B. Do Emprego dos Anesthesicos durante o Trabalho de Parto, 1876. Tese, Rio de Janeiro: Faculdade de Medicina do Rio de Janeiro. CORRÊA, M. As Ilusões da Liberdade: a escola Nina Rodrigues e a antropologia no Brasil, 1982. Tese, São Paulo: Universidade de São Paulo.

FERREIRA, E. L. L. A Puericultura Intra-Uterina na Formação da Prole, 1906. Tese, Bahia: Faculdade de Medicina da Bahia.

GUÉRIOS, F. Aleitamento, 1922. Tese, Paraná: Faculdade de Medicina do Paraná. GUIMARÃES, G. C. S. Da Esterilidade Provocada, 1912. Tese, Bahia: Faculdade de Medicina da Bahia.

JORGE, A. A. A. A Puberdade na Mulher, 1905. Tese, Bahia: Faculdade de Medicina da Bahia.

LIMA, L. G. Ligeiras Considerações sobre o Valor da Palpação Abdominal no Diagnóstico da Gravidez, 1909. Tese, Bahia: Faculdade de Medicina da Bahia. 
LOPES, R. V. Paralelo entre os Métodos Preconizados na Operação Cesareana, 1887. Tese, Bahia: Faculdade de Medicina da Bahia.

MARTINS, A. P. Mulheres, Luta e Poder, 1986. Monografia, Curitiba: Universidade Federal do Paraná.

MOURA, M. L. A. Etiologia da Menstruação, 1914. Tese, Bahia: Faculdade de Medicina da Bahia.

NUNES, S. A. Medicina Social e Regulação do Corpo Feminino, 1982. Dissertação, Rio de Janeiro: Universidade do Estado do Rio de Janeiro. PARAÍSO, O. S. Ligeiro Estudo do Parto nas Bacias Viciadas, 1910. Tese, Bahia: Faculdade de Medicina da Bahia.

RAMALHO, M. P. Higiene na Puberdade da Mulher, 1906. Tese, Bahia: Faculdade de Medicina da Bahia.

RAMOS, H. Da Anamnese na Ginecologia. 1918. Tese, Bahia: Faculdade de Medicina da Bahia.

RIBEIRO, J. F. Da Puberdade na Mulher, 1907. Tese, Bahia: Faculdade de Medicina da Bahia.

SANTOS JUNIOR, M. C. Hysteria, 1878. Tese, Rio de Janeiro: Faculdade de Medicina do Rio de Janeiro.

SILVA, J. D. Das Causa da Histeria, 1906. Tese, Bahia: Faculdade de Medicina da Bahia.

SOARES, P. A. O. A Puberdade na Mulher, 1913. Tese, Bahia: Faculdade de Medicina da Bahia.

SOUZA, M. L. B. Parto, Parteiras e Parturientes: Mme. Durocher e sua época, 1998. Tese, São Paulo: Universidade de São Paulo.

TELLES, A. L. Da Importância dos Exames Ginecológicos em Medicina Mental, 1930. Tese, Bahia: Faculdade de Medicina da Bahia.

TRINDADE, E. M. C. Clotildes ou Marias: mulheres de Curitiba na Primeira República, 1992. Tese, São Paulo: Universidade de São Paulo. 


\section{LIVROS E ARTIGOS}

ADEODATO FILHO, J. O Ensino da Clínica Obstétrica na Universidade da Bahia: subsídios para o seu histórico desde a sua fundação até a época presente. Salvador: Universidade Federal da Bahia, 1967.

AGASSIZ, J. L. \& AGASSIZ, E. Viagem ao Brasil: 1865-1866. Belo Horizonte/ São Paulo: Itatiaia/Edusp, 1975. (Apresentação de Mário Guimarães Ferri) A MATERNIDADE DO RIO DE JANEIRO. In: VIII Congresso Médico Brasileiro. Rio de Janeiro: Livraria Editora Leite Ribeiro, 1918. (Coleção dos trabalhos apresentados)

ALENCASTRO, L. F. Vida privada e ordem privada no Império. In: NOVAES, F. (Org.) História da Vida Privada no Brasil. São Paulo: Companhia das Letras, 1997.

ALGRANTI, L. M. Honradas e Devotas: mulheres da colônia - condição feminina nos conventos e recolhimentos do Sudeste do Brasil (1750-1822). Rio de Janeiro/Brasília: José Olympio/Edunb, 1993.

ALGRANTI, L. M. Educação feminina: vozes dissonantes no século XVIII e a prática colonial. In: BLAJ, I. \& MONTEIRO, J. M. (Orgs.) História \& Utopias: textos apresentados no XVII Simpósio Nacional de História. São Paulo: Anpuh, 1996.

ALLAERT, P. Quelques réflexions sur les nudités artistiques considéreés au point de vue de la moralité. In: BOLOGNE, J. (Org.) História do Pudor. Rio de Janeiro: Delfos, 1990.

ANDAHAZI, F. O Anatomista. Rio de Janeiro: Relume-Dumará, 1997.

ANTUNES, J. L. F. Medicina, Leis e Moral: pensamento médico e comportamento no Brasil - 1870-1930. São Paulo: Unesp, 1999.

ARIÈS, P. História Social da Criança e da Família. Rio de Janeiro: Guanabara, 1981.

ARON, J. P. Miserable et Glorieuse: la femme du XIX $X^{e}$ siècle. Paris: Fayard, 1980.

AZEVEDO, C. M. Onda Negra, Medo Branco: os negros no imaginário das elites - século XIX. Rio de Janeiro: Paz e Terra, 1987.

AZEVEDO, M. A faculdade de medicina do Rio de Janeiro. Revista do Instituto Histórico e Geográfico Brasileiro. 34/35: 397-418, 1867.

BADINTER, E. Um Amor Conquistado: o mito do amor materno. Rio de Janeiro: Nova Fronteira, 1985.

BAKER-BANFIELD, B. The spermatic economy. Feminist Studies, 1, 1972. 
BARBAUT, J. O Nascimento através dos Tempos. Lisboa: Terramar, 1991.

BARRETO, T. Estudos de Sociologia. Rio de Janeiro: Instituto Nacional do Livro, 1962.

BARRETO, T. A Questão do Poder Moderador e Outros Ensaios. Petrópolis: Vozes, 1977.

BARTHES, R. Literatura e Realidade: o que é o realismo? Lisboa: Publicações Dom Quixote, 1984.

BAUDELAIRE, C. Sobre a Modernidade. Rio de Janeiro: Paz e Terra, 1996. BERTHIER. Des Névroses Menstruelles ou la Menstruation dans ses Rapports avec les Maladies Nerveuses et Mentales. Paris: Adrien Delahaye, 1874. BIENVILLE, D. T. A Ninfomania ou Tratado sobre o Furor Uterino. Porto Alegre: L\&PM, 1996. (1.ed, 1783 - Tradução de Lucia Leiria)

BLAKE, A. V. A. S. Diccionário Bibliographico Brazileiro. Rio de Janeiro: Imprensa Nacional, 1893. 2V.

BLEIR, R. Science and Gender: a critique of biology and its theories on women. Nova Iorque: Pergamon, 1984.

BOlogne, J. C. História do Pudor. Rio de Janeiro: Delfos, 1990.

BRACK, D. C. Displaced the midwife by the male physician. In: HUBBARD, R. et al. (Eds.) Biological Woman: the convenient myth. Rochester: Schenkman Books, 1982.

BROWN, P. Corpo e Sociedade: o homem, a mulher e a renúncia sexual no início do cristianismo. Rio de Janeiro: Zahar, 1990.

BUMM, E. Précis d'Obstétrique. Lausanne: Librairie Payot, 1914.

BUSH, M. The rise of sex manual. History Today, 49(2): 36-42, feb., 1999. CANGuilhem, G. O Normal e o Patológico. Rio de Janeiro: ForenseUniversitária, 1995.

CASSEL, J. The woman in the surgeon's body: understanding difference. American Anthropologist, 98(1): 41-53, 1996.

CASTRO, D. D. B. Cartas Sobre a Educação de Cora do Dr. José Lino Coutinho. Salvador: Beneditina, 1977.

CASTRO, D. D. B. A Mulher Submissa: teses da Faculdade de Medicina da Bahia no século XIX. Salvador: Press Color, 1996.

CASTRO, T. L. A Mulher e a Sociogenia. Rio de Janeiro: Casa da Moeda, 1893. CERTEAU, M. de. A Escrita da História. Rio de Janeiro: ForenseUniversitária, 1982.

CHAilly-HONORÉ. Traité Pratique de l'Art des Accouchements. Paris: J.B. Bailliere et Fils, 1861. 
CHALHOUB, S. Cidade Febril: cortiços e epidemias na Corte Imperial. São Paulo: Companhia das Letras, 1996.

CHERNOVIZ, P. L. N. Diccionario de Medicina Popular e das Sciencias Accessorias para Uso das Famílias. Paris: Roger \& Chernoviz, 1890. v.2.

COBRA, E. N. Virgindade anti-higiênica. In: COBRA, E. N. (Org.) Visões do Passado, Previsões do Futuro. Rio de Janeiro/Goiânia: Tempo Brasileiro/ UFG, 1996. (Edição da autora, 1924)

CORBIN, A. O segredo do indivíduo. In: DUBY, G. \& ARIÈS, P. (Orgs.) História da Vida Privada: da Revolução Francesa à Primeira Guerra. São Paulo: Companhia das Letras, 1991.

CORBIN, A. Gritos e cochilos. In: PERROT, M. (Org.) São Paulo: Companhia das Letras, 1995.

COSER, L. Hombre de Ideas: el punto de vista de un sociologo. Mexico: Fondo de Cultura Económica, 1968.

COSTA, A. \& BRUSCHINI, C. (Orgs.) Entre a Virtude e o Pecado. Rio de Janeiro/ São Paulo: Rosa dos Tempos/Fundação Carlos Chagas, 1992.

COSTA, J. F. Ordem Médica, Norma Familiar. Rio de Janeiro: Graal, 1979.

COUTINHO, E. Menstruação: a sangria inútil. São Paulo: Editora Gente, 1996. COUTINHO, J. L. Cartas Sobre a Educação de Cora, Seguido de um Catecismo Moral, Político e Religioso. Salvador: Typographia Carlos Poggetti, 1849. (Publicado por João Gualberto de Passos)

COTT, N. F. Passionlesness: an interpretation of victorian sexual ideology. Signs, 4: 219-236, 1978.

CRAMPE-CASNABET, M. A mulher no pensamento filosófico do século XVIII. In: DUBY, G. \& PERROT, M. (Orgs.) História das Mulheres: do Renascimento à Idade Moderna. Porto/São Paulo: Afrontamento/Ebradil, 1991.

DARMON, P. Médicos e Assassinos na Belle Époque: a medicalização do crime. Rio de Janeiro: Paz e Terra, 1991.

DAVIN, A. Imperialism and motherhood. History Worsho: a journal of socialist Historians. 5.ed. Spring, 1978.

DEBAY, A. Hygiene e Physiologia do Amor nos dois Sexos. Rio de Janeiro: H. Garnier, 1901.

DEGLER, C. N. What ought to be and what was: women's sexuality em the nineteenth century. American Historical Review, 79(5): 1467-1490. dec., 1974.

DEL PRIORE, M. A maternidade da mulher negra no período colonial brasileiro. Estudos Cedhal, 4, 1989. 
DEL PRIORE, M. Ao Sul do Corpo: condição feminina, maternidades e mentalidades no Brasil Colônia. Rio de Janeiro/Brasília: José Olympio/Edunb, 1993. DELUMEAU, J. A Civilização do Renascimento. Lisboa: Editorial Estampa, 1994. V.II.

DEPAUL, J. A. H. Leçons de Clinique Obstétricale. Paris: Adrien Delahaye, 1876. DIDEROT, D. Sobre as mulheres. In: THOMAS, A. L. (Org.) O Que É uma Mulher? Um debate: A. L. Thomas, Diderot, Madame D'Epinay. Rio de Janeiro: Nova Fronteira, 1991. (Prefaciado por E. Badinter)

DIEPGEN, P. Historia de la Medicina. Barcelona: Labor, 1932.

DIJKSTRA, B. Idols of Perversity: fantasies of feminine evil in fin-de siècle culture.

Nova Iorque: Oxford University Press, 1988.

DONZElOT, J. A Polícia das Famílias. Rio de Janeiro: Graal, 1986.

DOTTIN-ORSINI, M. A Mulher que Eles Chamavam Fatal: textos e imagens da misoginia fin-de-siècle. Rio de Janeiro: Rocco, 1996.

DUBY, G. A Mulher, o Cavaleiro e o Padre. Lisboa: Dom Quixote, 1988.

DUBY, G. \& PERROT, M. (Orgs.) História das Mulheres: o século XIX. Porto/ São Paulo: Edições Afrontamento/Ebradil, 1994.

EHRENREICH, B. \& ENGLISH, D. Witches, Midwives and Nurses: a history of women healers. Nova Iorque: The Feminist Press, 1973.

EHRENREICH, B. \& ENGLISH, D. For Her own Good: 150 years of expert's advice to women. Nova Iorque: Doubleday Anchor, 1979.

ELLIS, H. Man and Woman: a study of human secondary sexual characteristics, 1894.

EXPILLY, C. Mulheres e Costumes do Brasil. São Paulo: Editora Nacional, 1977. FABRE. Précis d'Obstétrique. Paris: Libraire J. B. Baillière et Fils, 1910.

FLACK, I. H. Eternal Eve: the history of gynecology and obstetrics. Nova Iorque: Doubleday \& Company, 1951.

FOUCAULT, M. História da Sexualidade: a vontade de saber. Rio de Janeiro: Graal, 1980a.

FOUCAUlT, M. O Nascimento da Clínica. Rio de Janeiro: ForenseUniversitária, $1980 \mathrm{~b}$.

FOUCAULT, M. Herculine Barbin: o diário de uma hermafrodita. Rio de Janeiro: Francisco Alves, 1982.

FOUCAULT, M. História da sexualidade: o uso dos prazeres. Rio de Janeiro: Graal, 1984.

FOUCAULT, M. Microfísica do Poder. Rio de Janeiro: Graal, 1985.

FOUCAULT, M. Vigiar e Punir: história da violência nas prisões. Petrópolis: Vozes, 1986. 
FOUCAULT, M. A Arqueologia do Saber. Rio de Janeiro: Forense-Universitária, 1987.

FRENCH, R. D. Antivivisection and Medical Science in Vitorian Society. Princeton: Princeton University Press, 1975.

FREYRE, G. Casa-Grande \& Senzala. 29.ed. Rio de Janeiro: Record, 1992. GARNIER, P. As Anomalias Sexuaes. Rio de Janeiro: H. Garnier Livreiro Editor, 1889. GAY, P. A Educação dos Sentidos. São Paulo: Companhia das Letras, 1988.

GÉLIS, J. Sages-femmes et accoucheurs: l'obstétrique populaire aux XVII et XVIII ${ }^{e}$ siècles. Annales ESC, 32(5): 927-957, 1977.

GÉLIS, J. L'Arbre et le Fruit: la naissance dans l'Occident moderne - XVI'-XIX siècle. Paris: Fayard, 1984.

GOMBRICH, E. H. Arte e Ilusão: um estudo da psicologia da representação pictórica. São Paulo: Martins Fontes, 1986.

GOULD, S. J. Dedo Mindinho e seus Vizinhos: ensaios de história natural. São Paulo: Companhia das Letras, 1993.

GREER, G. A Mulher Inteira. Rio de Janeiro: Record, 2001.

GRONEMAN, C. Nymphomania: the historical construction of female sexuality. Signs: journal of women in culture and society, 2(19): 337$367,1994$.

HAHNER, J. A Mulher Brasileira e suas Lutas Sociais e Políticas: 1850-1937. São Paulo: Brasiliense, 1981.

HARAWAY, D. In the beginning was the word: the genesis of biological theory. Signs: journal of women in culture and society, 3(6): 469-481, 1981.

HARAWAY, D. Saberes localizados: a questão da ciência para o feminismo e o privilégio da perspectiva parcial. Cadernos Pagu, (5): 7-41, 1995.

HERSCHMAN, M. \& PEREIRA, C. A. (Orgs.) A Invenção do Brasil Moderno: medicina, educação e engenharia nos anos 20 e 30. Rio de Janeiro: Rocco, 1994.

HIPÓCRATES. Aforismos. São Paulo: Edições Zumbi, 1959. (Tradução do Dr. José Dias de Moraes)

HOBSBAWM, E. A Era do Capital: 1848-1875. Rio de Janeiro: Paz e Terra, 1997. HOFFMAN, P. La Femme dans la Penseé des Lumières. Paris: Edition Ophrys, 1976. HUBBARD, R. et al. Biological Woman: the convenient myth. Rochester: Schenkman Bookes Inc., 1982.

ILLICH, I. Gender. Nova Iorque: Pantheon Books, 1983.

IMHOFF, A. La surmortalité des femmes mariées em age de prcréation: um indice de la condition féminine au XIX ${ }^{e}$ siècle. In: Annales de Démographie Historique. Démographie Historique et Condition Féminine. Paris: Editions de l"Ecole des Hautes Etudes em Sciences Sociales, 1981. 
JAGGAR, A. M. \& BORDO, S. R. (Orgs.) Gênero, Corpo, Conhecimento. Rio de Janeiro: Rosa dos Tempos, 1997.

JAGUARIBE FILHO, D. J. N. Arte de Formar Homens de Bem. São Paulo: Typographia do Correio Paulistano, 1880.

JONES, L. Social darwinism revisited. History Today, 48(8): 6-8, aug., 1998. JORDANOVA, L. Sexual Visions: images of gender in science and medicine between the eighteenth and twentieth centuries. Londres: Harvester Wheatsheaf, 1989. JOSEPH, I. Tactiques et figures disciplinaires. Recherches - disciplines a domicile: l'edification de la famille, 1977.

KELLER, E. F. Reflections on Gender and Science. Nova Iorque: Yale University Press, 1985.

KELLY, J. Early feminist theory and the querelle des femmmes: 1400-

1789. Signs: journal of women in culture and society, 8(1): 4-18, 1982. KNIBIEHLER, Y. Les médecins et la 'nature féminine' au temps du Code Civil. Annales ESC, 4: 824-845, juil.-aoút, 1976.

KRAFT-EBING, R. Psychopathia Sexualis. Paris: Payot, 1886.

KRAMER, H. \& SPRENGER, J. O Martelo das Feiticeiras: Malleus Maleficarum.

Rio de Janeiro: Rosa dos Tempos, 1991. (Tradução de Paulo Fróes)

LAGET, M. La naissance aux siècles classiques: pratique des accouchements et attitudes collectives em France aux XVII et XVIII ${ }^{e}$ siècles. Annales ESC, 32(5): 950-992, 1977.

LAQUEUR, T. Makinfg Sex: body and gender from the greeks to Freud. Cambridge: Harvard University Press, 1992.

LASLETT, P. The age of menarche in europe since the eighteenth century. The Journal do Interdisciplinary History, 2(2): 221-236, 1971.

LAURETIS, T. de. A tecnologia do gênero. In: HOLLANDA, H. B. (Org.) Tendências e Impasses: o feminismo como crítica da cultura. Rio de Janeiro: Rocco, 1994. LAWRENCE, C. Incommunicable knowledge: science, technology and the clinical art in Britain. 1850-1914. Journal of Contemporary History, 20(4): 503-518, oct., 1985.

LEBLOND, A. Triaté Élémentaire de Chirurgie Gynécologique. Paris: H. Lauwereyens Librairie-Éditeur, 1878.

LEBOYER, F. Nascer Sorrindo. São Paulo: Brasiliense, 1979.

LEITE, M. M. A Condição Feminina no Rio de Janeiro no Século XIX. São Paulo/ Brasília: Hucitec/INL, 1984.

LENSKYD, H. Out of Bonds: women, sport and sexuality. Toronto: The Women's Press, 1986. 
LEVER, M. L'antiféminisme du Moyen Âge à la Révolution. L'Histoire, 54: 38-51, mars, 1983.

LIMA, H. O Pensamento Vivo de Tobias Barreto. São Paulo: Livraria Martins Editora, 1942.

LINEBAUGH, P. The tyburn riot against the surgeons. In: HAY, D. et. al. (Eds.) Albion's Fatal Tree: crime and society in eighteenth century England. Londres: Penguin Books, 1975.

LOBO, F. B. O ensino da medicina no Rio de Janeiro. Revista do Instituto Histórico e Geográfico Brasileiro, 260: 3-115, 1963.

LOBO, F. B. A biblioteca da Faculdade de Medicina do Rio de Janeiro no Império. Revista do Instituto Histórico e Geográfico Brasileiro, 334: 19$37,1982$.

LOMbroso, C. \& FERRERO, G. La Donna Delinquente: la prostituta e la donna normale. 4.ed. Torino: Fratelli Bocca Editori, 1923.

LOOMIS, F. Confissões de um Médico de Senhoras. Porto Alegre: Livraria do Globo, 1941.

LUZ, M. (Org.) Medicina e Ordem Política Brasileira. Rio de Janeiro: Graal, 1982.

LYONS, A. S. \& PETRUCELLI, R. J. Medicine: illustrated history Nova Iorque: Abrams, 1987.

MACFARLANE, A. História do Amor e do Casamento: Inglaterra, 1300-1840. São Paulo: Companhia das Letras, 1990.

MACHADO, R. et al. Danação da Norma: medicina social e constituição da psiquiatria no Brasil. Rio de Janeiro: Graal, 1978.

MAGALHÃES, F. Lições de Clínica Obstétrica. Rio de Janeiro: Livraria Castilho, $1922 \mathrm{a}$.

MAGALHÃES, F. A Obstetrícia no Brasil. Rio de Janeiro: Livraria Editora Leite Ribeiro, $1922 \mathrm{~b}$.

MAGALHÃES, F. Obstetrícia Forense. Rio de Janeiro: Editora Guanabara, 1933.

MAGALHÃES, L. Fernando Magalhães: resumo biográfico coligido por sua filha. Rio de Janeiro: Jornal do Commercio, 1944.

MAgAlhães, F. Cartilha da Probidade. 3.ed. São Paulo: Edições Melhoramentos, 1951.

MAINES, R. The Technology of Orgasm: 'hysteria', the vibrator and women's sexual satisfaction. Baltimore: The Johns Hopkins University Press, 1999. MARCO, V. de. O Império da Cortesã - Lucíola: um perfil de José de Alencar. São Paulo: Martins Fontes, 1986. 
MARTENSEN, R. A transformação de Eva: os corpos das mulheres, medicina e cultura no início da Inglaterra Moderna. In: PORTER, R. \& TEICH, M. (Orgs.) Conhecimento Sexual, Ciência Sexual: a história das atitudes em relação à sexualidade. São Paulo: Unesp/Cambridge University Press, 1998.

MICHELET, J. L'Amour: ouvres complètes - XVIII. Paris: Flammarion, 1985. (1 a ed., 1858)

MICHELET, J. A Mulher. São Paulo: Martins Fontes, 1995. (1ª ed., 1859)

MITCHINSON, W. Gynecological operations on insane women: 1895-1911. Londres: Ontario, Journal of Social History, 15, 1985.

MONTGOMERY, M. Mulher: o negro do mundo - uma visão científica e humana do universo feminino. São Paulo: Editora Gente, 1997.

MORANTZ-SANCHEZ, R. Sympath and Science: women physicians in American medicine. Nova Iorque: Oxford University Press, 1985.

MOREL, A. A Questão Sexual. São Paulo: Companhia Editora Gente, 1905. MOSCUCCI, O. The Cience of Woman: gynecology and gender in England-18001929. Londres: Cambridge University Press, 1993.

MOTA, J. A.; LOPES, E. M. T. \& COSER, S. M .L. Júlio Afrânio Peixoto (1876-1947): ensaio biográfico. In: HERSHMANN, M. \& P. C. \& PEREIRA, C. (Orgs.) A Invenção do Brasil Moderno: medicina, educação e engenharia nos anos 20 - 30. Rio de janeiro: Rocco, 1994.

MOTT, M. L. De educadora à médica: trajetória de uma pioneira metodista. Revista Cogeime, 15, dez., 1999.

NÉRET, G. Gustav Klimt: 1862-1918. Colônia: Taschen, 1944.

OS CLÁSSICOS DA CIRURGIA. Rio de Janeiro: Laboratórios Silva AraújoRoussel, 1944.

OS IMPRESSIONISTAS. August Renoir. São Paulo: Editora Globo, 1944.

PEIXOTO, A. A Educação da Mulher. São Paulo: Companhia Editora Nacional, 1936. PEIXOTO, A. A Esfinge. Rio de Janeiro: W. M. Jackson Editores, 1991.

PEIXOTO, A. Medicina Legal. Rio de Janeiro: Livraria Francisco Alves, 1946. v.1. - Medicina Forense.

PERROT, M. De Marianne a Lulu: as imagens da mulher. In: SANT'ANNA,

D. B. (Org.) Políticas do Corpo. São Paulo: Estação Liberdade, 1995.

PETER, J. P. Les médecins et les femmes. In: ARON, J. P. (Org.) Misérable et Glorieuse: la femme du XIX $X^{e}$ siècle. Paris: Fayard, 1981.

PIERUCCI, A. F. Ciladas da Diferença. São Paulo: Editora 34, 1999.

PINARD, A. \& WALLICH, V. Traitement de l'Infection Puerpérale. Paris: G. Steinheil, 1896. 
POINTON, M. Interior portraits: women, physiology and male artist. Feminist Review, 22: 5-22, feb., 1986.

POOVEY, M. Scenes of an indelicate character: the medical 'treatment' of victorian women. In: GALLAGHER, C. \& LAQUEUR, T. (Eds.) The Making of the Modern Body. Califórnia: University of California Press, 1987. POUILLET, T. De L'onanisme Chez la Femme: ses formes, ses causes, ses signes, ses conséquences et son traitement. 7.ed. Paris: Librairie Vigot Frères, 1897.

RACIBORSKI, A. Traité de la Menstruation. Paris: J. B. Baillière et Fils, 1868. RAGO, M. Os Prazeres da Noite: prostituição e códigos da sexualidade feminina em São Paulo - 1890-1930. Rio de Janeiro: Paz e Terra, 1991.

REIS, A. D. Cora: lições de comportamento na Bahia do século XIX. Salvador: Centro de Estudos Baianos da Ufba, 2000.

REIS, J. J. A Morte é uma Festa: ritos fúnebres e revolta popular no Brasil do século XIX. São Paulo: Companhia das Letras, 1998.

RENOUARD, P. V. Histoire de la Médicine. Paris: J. B. Baillière, 1846.

RIBEIRO, L. Afrânio Peixoto. Rio de Janeiro: Ed. Cndé, 1950.

RIBEIRO, L. F. Mulheres de Papel: um estudo do imaginário em José de Alencar e Machado de Assis. Rio de Janeiro: Eduff, 1996.

RIBEIRO, M. Temas de Etnologia: maternidade. Lisboa: Livros Horizonte, 1990. RIBEIRO, M. A. P. A Faculdade de Medicina da Bahia na Visão de seus Memorialistas - 1854-1924. Salvador: Edufba, 1997.

RIBEIRO, M. M. A Ciência dos Trópicos: a arte médica no Brasil do século XVIII. São Paulo: Hucitec, 1997.

ROHDEN, F. Uma Ciência da Diferença: sexo e gênero na medicina da mulher.

Rio de Janeiro: Editora Fiocruz, 2001.

RONAN, C. A. História Ilustrada da Ciência da Universidade de Cambridge: da Renascença à Revolução Científica. Rio de Janeiro: Zahar, 1997.

ROSEN, G. A evolução da medicina social. In: NUNES, E. D. (Org.) Medicina

Social: aspectos históricos e teóricos. São Paulo: Global, 1983.

ROUSSELLE, A. Observation féminine et idéologie masculine: le corps de la femme d'après les médecins grecs. Annales ESC, 35(5): 1089-1115, 1980.

ROUSSElle, A. Pornéia: sexualidade e amor no mundo antigo. São Paulo: Brasiliense, 1984.

RUSSELL-WOOD, A . J. R. Fidalgos e Filantropos: a Santa Casa de Misericórdia da Bahia - 1550-1755. Brasília: Edunb, 1981.

SAID, E. W. Orientalismo: o Oriente como invenção do Ocidente. São Paulo: Companhia das Letras, 1996. 
SANT'ANNA, A. R. O Canibalismo Amoroso. São Paulo: Brasiliense, 1984.

SANTOS, J. R. Clínica Obstétrica. Rio de Janeiro: Typographia de P. Braga \& Cia., 1877. v.1.

SANTOS, J. R. Scientificamente é Possível a Esterilização da Mulher? Rio de Janeiro: s.n., 1893.

SANTOS FILHO, L. História Geral da Medicina Brasileira. São Paulo: Hucitec, 1991.

SCHIEBINGER, L. Skeletons in the closet: the first illustrations of female sckeleton in eighteenth-century anatomy. In: GALLAGHER, C. \& LAQUEUR, T. (Eds.) The Making of the Modern Body. Berkeley: University of California Press, 1987.

SCHIEBINGER, L. The Mind Has no Sex? Women in the origins of modern science. Cambridge: Harvard University Press, 1989.

SCHIEBINGER, L. Nature's Body: sexual politics and the making of modern science. Londres: Pandora, 1994.

SCHOPENHAUER, A. Pensées et Fragments. Paris: Félix Alcan Éditeur, 1900.

SCHWARCZ, L. M. O Espetáculo das Raças: cientistas, instituições e a questão racial no Brasil - 1870-1930. São Paulo: Companhia das Letras, 1993.

SCLIAR, M. A Paixão Transformada: história da medicina na literatura. São Paulo: Companhia das Letras, 1996.

SHORTER, E. A History of Women's Bodies. Londres: Pelican Books, 1984.

SHORTER, E. A Formação da Famúlia Moderna. Lisboa: Terramar, 1985.

SHOWALTER, E. Anarquia Sexual: sexo e cultura no fin de siècle. Rio de Janeiro: Rocco, 1993.

SHOWALTER, E. \& SHOWALTER, E. Victorian women and menstruation.

In: VICINUS, M. (Ed.) Suffer and Be Still: women in the victorian age. Bloomington/Indianapolis: Indiana University Press, 1994.

SIGAUD, J. F. Clínica de partos. In: Diário da Saúde. Rio de Janeiro, 1835. SILVA, A. A Primeira Médica do Brasil. Rio de Janeiro: Irmãos Pongetti, 1954. SILVA, F. R. Memória Histórica dos Acontecimentos Notáveis Ocorridos no Anno de 1861 na Faculdade de Medicina da Bahia. Salvador: Carlos Poggeti, 1862. SIMPSON, J. Clinique Obstétricale et Gynécologique. Paris: J. B. Baillière et Fils, 1874.

SKIDMORE, T. E. Raça e Nacionalidade no Pensamento Brasileiro. Rio de Janeiro: Paz e Terra, 1976.

SOUCASAUX, N. Novas Perspectivas em Ginecologia. Rio de Janeiro: Imago, 1990. 
SOUCASAUX, N. Os Órgãos Sexuais Femininos: forma, função, símbolo e arquétipo. Rio de Janeiro: Imago, 1993.

SouzA, J. A. de. Propedêutica Gynecológica. Salvador: Livraria Duas Américas, 1929.

SPEERT, H. Iconographia Gyniatrica: a pictorial history of gynecology and obstetrics. Filadélfia: F. A Davis, 1973.

SPENCER, H. Educação Intellectual, Moral e Physica. Porto: Livraria Chardron, 1927.

STALL, S. What a Young Husband Ought to Know. Filadélfia: The Vir Publishing Company, 1907.

STEPAN, N. L. Raça e gênero: o papel da analogia na ciência. In: HOLLANDA, H. B. (Org.) Tendências e Impasses: o feminismo como crítica da cultura. Rio de Janeiro: Rocco, 1994.

SÜSSEKIND, F. Tal Brasil, Qual Romance? Rio de Janeiro: Achiamé, 1984.

TARNIER, S. De la Fiévre Puerpérale: observée a l'hospice de la maternité. Paris:

J. B. Baillière et Fils, 1858.

TATLOCK, L. Speculum feminarum: gendered perspective on obstetrics and gynecology in early Germany. Signs: journal of women in culture and society, 17(4): 725-760, 1992.

THEBAUD, F. Quand nos Grand-mères Donnaient la Vie: la maternité em France dans l'entre-deux-guerres. Lion: Presses Universitaires de Lyon, 1986.

THOMAS, A. L. O Que é uma Mulher? Um debate. Rio de Janeiro: Nova Fronteira, 1991. (Prefácio de E. Badinter - 1.ed., 1772).

THORWALD, J. O Século dos Cirurgiões. São Paulo: Hemus, s.d.

TODOROV, T. Nós e os Outros: a reflexão francesa sobre a diversidade humana. Rio de Janeiro: Zahar, 1993.

VELPEAU, A. Traité Complet de l'Art des Accouchements, ou Tocologie Théorique et Pratique. Paris: J. B. Baillière et Fils, 1835.

VIANNA, H. As Aparadeiras e as Sendeironas: seu folclore. Salvador: Centro de Estudos Baianos, 1978.

WALSH, M. R. The quirls of a woman's brain. In: HUBBARD, R. et al. (Eds.) Biological Woman: the convenient myth. Rochester: Schenkman Books, 1982.

WARNER, M. Monuments and Maidens: the allegory of female form. Berkeley/ Los Angeles: University of California Press, 2000.

WEST, C. Leçons sur les Maladies des Femmes. Paris: F. Savy, 1870. 
WILSHIRE, D. Os usos do mito, da imagem e do corpo da mulher na reimaginação do conhecimento. In: JAGGAR, A. M. \& BORDO, S. R. (Orgs.) Gênero, Corpo, Conhecimento. Rio de Janeiro: Rosa dos Tempos, 1997.

WOLF, N. O Mito da Beleza: como as imagens de beleza são usadas contra as mulheres. Rio de Janeiro: Rocco, 1992.

WOOD, A. D. The fashionable diseases: women's complaints and their treatment in Ninenteenth Century America. The Journal of Interdisciplinary History, 4(1): 25-52, 1973. 
Formato: $16 \times 23 \mathrm{~cm}$

Tipologia: Marigold e Carmina Light

Papel: Pólen Bold $70 \mathrm{~g} / \mathrm{m}^{2}$ (miolo)

Cartão Supremo $250 \mathrm{~g} / \mathrm{m}^{2}$ (capa)

Fotolitos: Laser vegetal (miolo)

Graftipo Gráfica e Editora Ltda. (capa)

Impressão e acabamento: Imprinta Gráfica e Editora Ltda.

Rio de Janeiro, novembro de 2004

Não encontrando nossos títulos em livrarias, contactar a EDITORA FIOCRUZ: Av. Brasil, 4036 - Térreo, s. 112, Manguinhos - 21041-361 - Rio de Janeiro - RJ Tel.: (21) 3882-9039 e 3882-9041 - Telefax: (21) 3882-9006

e-mail: editora@fiocruz.br 